\title{
PONTIUS PILATE \\ IN \\ HISTORY AND INTERPRETATION
}

\author{
Helen Katharine Bond
}

\begin{abstract}
This thesis reconstructs what we know of the historical prefect of Judaea and looks at the way in which he is used as a literary character in the works of six first century authors: Philo, Josephus and the writers of the four gospels.

The first chapter gives a general introduction to the history and formation of the imperial Roman province of Judaea and the powers and duties of its equestrian governors with particular reference to Pilate. This draws upon Roman and Jewish sources, both literary and epigraphic. The next two chapters examine the references to Pilate in the Jewish writers Philo and Josephus. The apologetic and theological bias of each author is examined first before going on to consider how this bias has influenced each one's portrayal of Pilate. After this, some consideration is given to the historical events behind the narratives.

The next four chapters deal with the portrayal of Pilate in each gospel in turn. After a consideration of the general themes in each evangelist's passion narrative, each chapter gives a description of how each writer presents the prefect as a literary character, asking how a first century reader would have understood and interpreted Pilate's actions. When this has been established each chapter asks what this portrayal shows about the author's attitude towards the Roman state, symbolised by Pilate, and what kind of community found this useful. After all four Roman trial narratives in the gospels have been analysed, the possible historical events behind them will be discussed.

The conclusion distinguishes between the 'historical Pilate', the Roman knight sent by Tiberius to take charge of the province of Judaea, and the different Pilates of interpretation preserved in the writings of six first century Jewish and Christian authors.
\end{abstract}




\section{PONTIUS PILATE \\ IN \\ HISTORY AND INTERPRETATION}

\section{Helen Katharine Bond}

The copyright of this thesis rests with the author.

No quotation from it should be published without her prior written consent and information derived from it should be acknowledged.

Submitted for the degree of PhD

Department of Theology

Durham University

1994 


\section{Contents}

Introduction 1

Aims of the Present Work 6

Methodology 8

Chapter 1:The Roman Province of Judaea and its Governor $\quad 10$

The Province:

Reasons fot the Formation of the Province in AD $6 \quad 10$

The Imperial Province 13

Relations between Judaea and Syria 14

The Duration and Scope of the Province 17

The Capital of the Province 19

The Governor:

Status 20

Length of Governorship $\quad 22$

The Title of the Governor of Judaea 23

The Powers and Duties of the Prefect of Judaea 26

Capital Jurisdiction $\quad 26$

Military Authority 28

Financial Powers of the Governor 29

The Governor and his Relations to the High Priest

Pontius Pilate $\quad 34$

Summary $\quad 43$

Chapter 2: Pilate in Philo 45

Text 46

The Context of Legatio 299-305 47

Theological and Political Apologetic in Philo's

The Theology behind the Legatio and In Flaccum 47

Political Apologetic in Philo's Historical Works 54

$\begin{array}{ll}\text { Philo's Pilate } & 57\end{array}$

The Historical Event: $\quad 58$

Pilate's Crime $\quad 58$

The Date of the Incident 66

$\begin{array}{ll}\text { Conclusion } & 67\end{array}$ 
The Jewish War

(a) Purposes 69

(b) Pilate in the Jewish War 73 $\begin{array}{ll}\text { Texts } & 73\end{array}$

Context 74

Apologetic Themes within the Two Stories $\quad 75$

The Characterization of Pilate in the War 77

Summary $\quad 82$

The Antiquities of the Jews

(a) Purposes 82

(b) Pilate in the Antiquities of the Jews 86

Texts 86

Context 87

Apologetic Themes within the Pilate Narratives in Antiquities $\quad 89$

The Characterization of Pilate in the Antiquities 94

Summary 99

The Historical Events: $\quad 99$

(1) The Standards
Date
100

Pilate's Actions $\quad 100$

The Jewish Objection 102

Events at Caesarea
(2) The Aqueduct

Pilate's Crime 106

The Jewish Objection 107

(3) The Execution of Jesus 109

(4) The Samaritan Uprising and Pilate's Return
to Rome

(a) The Samaritan Uprising 109

(b) Pilate's Departure $\quad 111$

$\begin{array}{ll}\text { Conclusion } & 113\end{array}$

Chapter 4: Pilate in Mark's Gospel 114

$\begin{array}{ll}\text { Text } & 115\end{array}$

Context 116

Mark's Passion Account 117

Apologetic Themes Culminating in Mark's Passion
Narrative

The Characterization of Pilate in Mark 123

The Handing over to Pilate 124

The Hearing before Pilate 125

Conclusion

136

Chapter 5: Pilate in Matthew's Gospel 140

Text 142

Context 143 
Matthew's Sources 144

Matthew's Special Interests Reflected in his Redaction of Mark 15:1-15

The Characterization of Pilate in Matthew 149

Matthew's Use of nigućv 155

$\begin{array}{ll}\text { Conclusion } & 158\end{array}$

Chapter 6: Pilate in Luke/Acts 160

The Contexts of Luke's References to Pilate 161

Sources Used by Luke in the Composition of his
Passion Narrative

Lukan Themes Influencing his Portrayal of Pilate 163

The Characterization of Pilate in Luke:

(a) References to Pilate before the Roman Trial 171

(b) The Characterization of Pilate in the Roman Trial 174

The Trial before Herod Antipas (23:8-11) 176

Pilate's Summing Up (23:13-15a) 178

Conflicting Verdicts $(23: 15 b-23) \quad 179$

Conclusion

The Sentence (23:24-5) 181

181

Chapter 7: Pilate in John's Gospel 185

Context 186

Sources Behind John's Passion Account 188

Important Johannine Themes Culminating in the
Trial before Pilate
189

The Characterization of Pilate 197

The Roman Trial:

Scene I(18:28-32) 198

Scene II $(18: 33-38 a) \quad 200$

Scene III $(18: 38 b-40) \quad 202$

Scene IV $(19: 1-3) \quad 205$

Scene V (19:4-8) 206

Scene VI (19:9-11) 210

Scene VII (19:12-16a) 212

The Title on the Cross 214

Conclusion 215

Chapter 8:Historical Events behind the Gospel Narratives 217

(a) The Historical Trial of Jesus 217

(b) Historical Events behind Lk 13:1 220

Conclusion 
The copyright of this thesis rests with the author. No quotation from it should be published without her prior written consent and information derived from it should be acknowledged.

I confirm that no part of the material offered has previously been submitted by me for a degree in this or in any other University.

Signed: Ytikiz K. Rnd
Date: 22nd septinter 1994. 


\section{INTRODUCTION}

That Jesus of Nazareth was crucified under Pontius Pilate, the fifth prefect of the imperial Roman province of Judaea, is one of the surest facts of Christianity; it is attested not only by the earliest Christian traditions but also by the Roman historian Tacitus (Annals 15.44). As the judge of Jesus, Pilate has earned an important place not only in the New Testament and Christian creeds but also in popular imagination. The picture of an official washing his hands in an attempt to avoid responsibility, or the eternally unanswerable question What is truth? (Jn 18:38) are inextricably linked with Pilate, even by those who profess little or no Christian commitment.

In view of Pilate's significance it is not surprising to find many varied treatments of the historical governor over the last century, both on an academic and on a popular literary level ${ }^{1}$. Two factors generally have influenced these presentations. First of all, the sources at the historian's disposal are relatively thin and those which are available appear to give contradictory views of Pilate. The Jewish writers Philo and Josephus describe Pilate in negative terms, a harsh, cruel man attempting to destroy the Jewish religion. The Christian gospels, however, are generally interpreted as presenting a governor who, although weak and indecisive, recognized the innocence of Jesus and attempted to save him from execution. To a large extent any reconstruction of the 'real Pilate' has depended upon the relative value set upon each source by the historian ${ }^{2}$. In the second place, several influential interpretations of Pilate over the last century appear to have been coloured, whether consciously or not, by the social and political environments of their authors. Thus these 'Pilates' may reflect as much the writer's contemporary society as first century Judaea under Pilate's administration.

At the turn of the century the standard work on Pilate was by G. A. Müller, Pontius Pilatus, der fünfte Prokurator von Judäa und Richter Jesu von Nazareth published in Stuttgart in 1888. Muiller's favourable view of the governor was largely based on Pilate's portrayal in the gospels and tended to dismiss the testimony of the Jewish writers as tendentious. Despite E. Schürer's picture of a contemptuous, intolerant and reckless Pilate in his

\footnotetext{
${ }^{1}$ The seventeenth and eighteenth centuries produced a vast amount of literature on Pilate; for a full bibliography of material prior to 1888 see G. A. Müller, Pontius, pp v-viii. \{Works cited in the following notes will be referred to by the first key word of their titles; for full details see the bibliography.\}

${ }^{2}$ There are, of course, many references to Pilate in Apocryphal writings but, due to limitations of space, this study will look at only first century sources.
} 
Geschichte des jüdischen Volkes im Zeitalter Jesu Christi (1886-1890), it was Müller's interpretation which was taken up and developed in Germany by $E$. von Dobschuitz (1904) and H. Peter (1907) ${ }^{1}$. Pilate was seen as a reasonably able governor finding himself faced with a series of difficult situations involving a turbulent race of people in a difficult province. In Britain, A. Souter, writing an article on Pilate in 1908, similarly concluded that whilst Pilate could show a lack of tact and was not the stuff from which heroes were made, he was 'doubtlessly in many respects a competent governor'2. F. Morrison, writing a popular account in 1939, presented a sympathetic portrayal of Pilate whose rule over Judaea rather resembled that of a British colonial governor ${ }^{3}$. C. Kraeling, writing in the Harvard Theological Review in 1942, argued that Pilate's actions in at least one incident were determined by thoroughly practical considerations rather than an arbitrary act of provocation as the Jewish sources would have us believe ${ }^{4}$. With few exceptions, this relatively favourable interpretation of Pilate, based largely on the characterization of the governor in the gospel accounts, dominated the first half of the twentieth century 5 .

In the former Soviet Union Pilate and acts associated with him, such as hand washing, were particularly prominent in works written during the Stalinist era. The weak Pilate of the gospels was regarded as a particularly appropriate figure to reflect the results of an abnegation of ethical responsibility, moral compromise and a devotion to selfish concerns such as several authors felt was fostered by Stalinist ideology. Paramount amongst these works was M. Bulgakov's The Master and Margarita written in 1938. In Bulgakov's original interpretation of the trial scenes Pilate becomes a

\footnotetext{
1 Von Dobschuit $\angle$, 'Pilatus'; Peter, 'Pontius'.

${ }^{2}$ A. Souter, 'Pilate'.

3 F. Morrison, Pilate.

${ }^{4} \mathrm{C}$. Kracling, 'Episode', referring to Pilate's erection of iconic standards in Jerusalem (Joscphus, War 2.169-174; Antiq 18:55-59). See Chapter 3, 'Pilate in Josephus', for fuller delails.

5 One notable cxception, however, was I. Broyde whose article 'Pilate' in the Jewish Encyclopaedia (1905) emphasized Pilate's cruelty. Though less negative than Broydé, G. T. Purves saw Pilate making little effort to understand the Jews, a man without high moral qualitics and of a fecble character, 'Pontius', Hastings Dictionary of the Bible (1900).

In response to R. Eisler's Messiah (ET 1931), this period also saw several works dcaling with strictly historical questions, particularly the precise dating of Pilate's administration; these offered no assessment of Pilate's competence as a governor or of his character. See for example U. Holzmeister, 'Wann' (1932); P.L. Hedley, 'Pilate's' (1934); S.J. de Laet, 'Successeur' (1939). M. Dibelius, 'Herodes' (1915), though a theological analysis of the Lukan trial narrative, offers no characterization of Pilate.
} 
credible and moving figure whose downfall is his own moral cowardice. By betraying his own personal feelings, Pilate is to suffer for all eternity ${ }^{1}$.

This favourable, or at worst weak, view of Pilate was shattered after World War II by E. Stauffer in Christus und die Caesaren (1948) and a number of works which followed ${ }^{2}$. He suggested that Pilate was the personal appointee of Sejanus, the allegedly anti-Jewish prefect of the Praetorian Guard. The conflicts recounted by Philo and Josephus and numismatic evidence illustrate a deliberately aggressive attempt to provoke the Jewish people, the enactment of a policy masterminded by Sejanus. The intention was to rouse the whole nation to open rebellion which was then to be brutally crushed, resulting in the annihilation of the entire race. Sejanus' fall in AD 31 , however, prevented the realisation of his plans and left Pilate in a precarious position, a precariousness adequately illustrated by the governor's vacillating behaviour in the trial of Jesus (which Stauffer concludes occurred in AD 33). In Stauffer's reconstruction of the extreme anti-Jewishness of Sejanus and Pilate and their world-wide attempt to annihilate the Jewish race it is difficult not to hear echoes of similar Nazi objectives only a few years previously.

In this interpretation the value of the Jewish sources has come into prominence; no longer are they seen as hopelessly biased and untrustworthy. In contrast to previous attempts to harmonize the conflicting portrayals of Pilate in the various sources (which, as we have seen, generally tended to put more emphasis on the evidence of the gospels), Stauffer's interpretation stressed the historical value of both Christian and Jewish tradition. This neatly created two Pilates - the Pilate of Philo and Josephus and the Pilate of the gospels - with a specific historical event - the fall of Sejanus - to account for the change.

This picture of Pilate's harsh unyielding character, riding roughshod over the religious sensitivities of the people he was sent to govern, has exerted a tremendous influence over Pilate research and still finds many adherents today. Stauffer's views were quickly endorsed by E. Bammel ${ }^{3}$ and taken up in

\footnotetext{
${ }^{1}$ M. Bulgakov The Master and Margarita (1938, first published 1966/7). See later Chingiz Aitmatov Plakha (The Place of the Skull), 1986, which also involves Pilate in a commentary on Stalinist Russia. In general see Margaret Ziolkowski, 'Pilate and Pilatism in Recent Russian Literature' in New Dimensions in Soviet Literature, ed. S. Duffin Graham, St Martin's Press, NY (1992), pp 164-181.

${ }^{2}$ Christ (ET 1955), especially pp 118-120, 103; 'Münzprägung' (1949/50), pp 51 1ff; Jerusalem (1957), pp 16-18. The link with Sejanus and an anti-Jewish conspiracy had already becn tentativcly expressed by A.D. Doyle in 1941, 'Pilate's'. He w rote: 'Perhaps Pilate was his appointment. Perhaps he inspired Pilate's intention of destroying Jewish customs', p 192. Stauffer, however, expressed these opinions much more forcibly, drawing on historical evidence to back them up.

3E. Bammel: 'Syrian ' (1950/1); 'Philos' (1952); 'Pilatus' (1961).
} 
particular by several Jewish writers. In 1961 P. Winter published his influential book On the Trial of Jesus, taking a similar line to Stauffer. Winter maintained that Philo's description of Pilate's brutal and vicious character was the most historically trustworthy we possess. H. Cohn, writing in 1967 agreed with this estimate, characterising Pilate as a governor full of 'wild wrath and insensate onslaughts' ${ }^{1}$. M. Stern in CRINT (1974) strongly criticized Pilate, agreeing with Stauffer in seeing a considerable deterioration between Jews and Rome throughout his term of office due to a series of clashes in line with Sejanan policy2. D.R. Schwartz, though less negative, claims that 'Pilate's tenure was probably one of continued underlying friction between governor and governed, now and then breaking out in brief incidents ${ }^{3}$.

The reconstruction of Stauffer and his followers has also had a profound effect upon non-Jewish scholarship. The revisers of Schürer, though not nearly so negative in their appraisal of Pilate's character and governorship as Stauffer, continued to uphold Schürer's original rather negative view of Pilatet. J. Blinzler, though aware of the bias behind the accounts of Philo and Josephus, regarded Pilate as contemptuous of the Jewish people in his province and eager to avail himself of every opportunity of letting them see it $^{5}$. P.L. Maier took up Stauffer's hypothesis of a Sejanan and a post-Sejanan phase in Pilate's governorship and on the basis of this similarly set the crucifixion in AD 336. E.M. Smallwood too in her book The Jews under Roman Rule (1976) agreed that Pilate exhibited a blatant disregard for his subjects' religious sensibilities, though she showed more caution with regard to Sejanus' alleged conspiracy, noting only that Pilate was 'possibly implementing Sejanus' policy 7 . Most recently Stauffer's hypothesis was endorsed by $\mathrm{H}$. Hoehner in his article on Pilate in the Dictionary of Jesus and the Gospels $(1992)^{8}$.

\footnotetext{
${ }^{1}$ H. Cohn Trial (1967).

${ }^{2}$ M. Stern, CRINT, pp 349-353.

3 'Pontius' (1992).

${ }^{4}$ E Schuirer, History (revised by G. Vermes and F. Millar), vol I, pp 383-387 (1973).

5J. Blinzler, Prozeß (1951); 'Pilatus' (1963).

6P.L. Maier, 'Scjanus' (1968); 'Episode' (1969); sce also his historical novel Pontius Pilate, (1968).

${ }^{7}$ E. M. Smallwood Jews, pp 160-170.

8 Similar vicws were expressed in Hoehner's earlier work Herod (1972), pp 172ff. For other unfavourable treatments of Pilate see F.J. Buckley, 'Pilate' (1967); L. Roth, 'Pontius' (1971); R. A. Horslcy and J. S. Hanson, Bandits (1985), pp 38-39. S. Sandmel, 'Pilate' (1962) and A. E. Hilliard-H. Clavier, 'Pilate' (1963) presented more neutral pictures of the governor.
} 
Yet right from the beginning Stauffer's views met with some opposition. In 1950 E. Fascher argued that Tiberius would not have allowed Pilate to remain in office for ten years if his rule were really so blatantly provocative and unpopular' ${ }^{1}$. In 1965, in an article entitled 'The Chronological Framework of the Ministry', H. E. W. Turner challenged Stauffer's theory on several grounds. In particular he cast doubt over Sejanus' anti-Judaism, a fact attested only by Philo and in an extremely apologetic work, and highlighted the deficiencies of our knowledge of numismatics for this period. Turner saw in Pilate a carelessness with respect to Jewish sensitivities but no deliberate policy of provocation pursued on instructions from Rome. A similar line was taken by $\mathrm{H}$. Wansbrough in 1966 who saw in Pilate a governor zealous in his attempts to honour the emperor, acting with the greatest possible leniency compatible with maintaining public order ${ }^{2}$. S.G. F. Brandon too refused to regard Pilate's actions as deliberately provocative ${ }^{3}$. A decisive step in favour of the 'not deliberately provocative' Pilate was taken in 1981 with the publication of J. P. Lémonon's book Pilate et le gouvernement de la Judée. According to Lémonon, what led to trouble with his Jewish subjects was not Sejanan influence but Pilate's character and conception of the role of a provincial prefect. He expected to be master in his own province, attempting to honour the emperor by bringing Judaea in line with other provinces and ignoring the sensitivities of the people in the process. He attempted to gain respect by use of force, a strategy which showed little political sense and earned him a poor reputation. In The Death of the Messiah (1994) ${ }^{4}$, R.E. Brown accepts that Pilate was not without very serious faults but, with Lémonon, suggests that Pilate was a much better governor than Philo's caricature would have us believe. B.C. McGing in 'Pontius Pilate and the Sources' (1991) 5 largely based himself upon Lémonon's reconstruction, though regarding Pilate slightly more favourably, arguing that such a view of Pilate in the Jewish sources - a governor prepared to confront the Jews and to resist them stubbornly, yet at the same time indecisive, able to give way and not inclined to bloodshed - could fairly easily be reconciled with the Pilate of the gospels. McGing's work highlights a growing tendency amongst all these last named scholars: no longer is it necessary to see a Pilate of Jewish writers and a diametrically opposed Pilate of Christian sources, with an historical

\footnotetext{
${ }^{1}$ E. Fascher 'Pontius' (1950).

${ }^{2}$ H. Wansbrough, 'Suffered' (1966).

${ }^{3}$ S.G.F. Brandon, 'Pontius' (1968).

${ }^{4}$ See particularly pp 695-705.

5B.C. McGing, 'Pontius' (1991).
} 
event, such as Sejanus' fall, to account for the change. For these writers a careful analysis of Philo and Josephus, read in their historical context and taking their individual biases into account, shows no real discrepancy with the Pilate encountered in Christian sources.

Pilate research today therefore broadly encompasses two different interpretations of the historical prefect. On one hand he is seen as deliberately provocative, of a callous disposition, merely a minion of Sejanus and his antiJewish plot. The events of the Jewish literature belong to the time before Sejanus' fall whilst the crucifixion of Jesus of Nazareth takes its place afterwards. The other approach rejects the theory of an anti-Jewish plot of Sejanus, reading all the sources in context and suggesting that there is no fundamental difference between the Pilate encountered in each one. With the recent publications of both Lémonon's book and McGing's article it is this latter approach which may perhaps gradually begin to gain wider acceptance.

\section{Aims of the Present Work}

Despite this interest in Pilate, there has never been a full length academic treatment of the historical governor in English. One aim of the present work is to provide such a compilation and assessment of the various literary, archaeological and numismatic sources relevant to the Judaean governor. Although my own interpretation will be generally similar to that taken by Lémonon and McGing, my historical reconstruction of each event will not always concur with theirs.

An historical assessment of Pilate is important - he was an historical man involved in an historical and historic trial - yet the major aim of this work lies in a slightly different direction. This is an attempt to see how this real historical figure was used by various Jewish and Christian authors of the first and early second centuries AD as a literary character in their works. How do Philo, Josephus and the four gospels portray Pilate and what apologetic concerns have shaped these interpretations of the governor? In particular, what do these differing literary presentations of Pilate tell us about their authors' attitudes towards the Roman state, symbolized and expressed through the Roman prefect? As the above survey of research illustrates, even modern writers can consciously or unconsciously allow their own contemporary situation to affect their description of Pilate. It is all the more likely that first century writers allowed their own situation to colour their portrayals: they were not engaged in constructing purely 'historical' accounts but were 
consciously interpreting historical events to speak to the needs of their readers or to produce a certain response. This is the case not only for the evangelists, whether writing for Christians facing persecution or not, but also for Josephus, writing to explain the causes of the Jewish revolt and to extol the virtues of Judaism, and Philo, in a letter exhorting the emperor Gaius to respect Jewish customs. It would be a mistake to regard the Jewish accounts of Pilate as 'historical' in contrast to the 'theological' portrayals of the gospels: all these presentations of Pilate to a greater or lesser extent reflect the apologetic aims and contemporary understandings of their authors. It is the political situations leading to such interpretations which I shall try to investigate.

The political background and apologetic of Josephus and Philo have been the subject of many articles and books and so this study will concentrate on that of the gospels. In the case of each gospel it is necessary to ask how Pilate is being presented and, in the case of Matthew and Luke, how significant are the changes from Mark's account ${ }^{1}$ What kind of communities would have found such presentations of the representative of Rome useful? In general, what does this say about the attitudes of various first century Christian communities towards their Roman overlords?

It is often assumed, and expressed quite clearly by Winter, that the various presentations of Pilate in the gospels take their place in a linear development in which Pilate becomes progressively friendlier towards Jesus and anxious to acquit him, whilst more and more blame is heaped upon the Jewish leaders. This process, beginning with Mark's gospel and ending with the apocryphal fourth century Gospel of Nicodemus, is claimed to be directly proportional to Roman persecution of Christianity. Winter writes: There is a definite connection between two facts: the more Christians are persecuted by the Roman State, the more generous becomes the depiction of Pontius Pilate as a witness to Jesus' innocence' 2 . Yet is this picture a little too simplistic? There is no evidence to suggest the existence of a gradual increase in Roman persecution of Christianity stretching from its earliest days until Constantine's victory at Milvian Bridge altered imperial policy; rather persecution, especially in the earliest century of Christianity, tended to be sporadic and confined to certain areas ${ }^{3}$. Suggested persecutions under Nero, Domitian or Trajan do not appear to have affected all Christians in every part of the

\footnotetext{
I shall follow the majority of scholars regarding the priority of Mark.

2 See Winter, Trial, p 59.

${ }^{3}$ See for example, A.N. Sherwin-White 'Persecutions', pp 199-213; P. Garnsey and R. Saller, Roman, p 202; G.E.M. de Ste Croix, 'Why?' p15, as he notes, persecution at this period was from below, that is the result of popular agitation coming to the governors' ears rather than a result of an imperial cdict.
} 
empire. It would appear rather odd then if four gospels emanating from different geographical parts of the first century empire were really to fit so neatly into such a development as is generally presumed. It would be much more reasonable to expect a complex variety of different interpretations of Pilate, addressing different political situations, without necessarily exhibiting any common line of development; quite possibly the author of a later gospel might portray Pilate in harsher terms than an earlier one if such a picture were more appropriate to the social or political needs of his readers. Furthermore, is it necessarily the case that a persecuted community would portray Pilate as favourable towards Jesus? This could undoubtedly be put to good apologetic effect if the gospel was generally aimed at a Roman readership; but if a gospel was written exclusively or principally in order to strengthen a Christian community in their belief or to encourage them at a time of persecution would a weak ineffectual Pilate be of much use? Surely in such circumstances a picture of Jesus quietly and courageously enduring a trial at the hands of a harsh Roman judge would be more relevant? The whole of the 'progressively friendlier Pilate' theory then needs careful re-examination in the light of the differing interpretations of Pilate found in the four canonical gospels.

\section{Methodology}

The first chapter gives a general introduction to the history and formation of the imperial Roman province of Judaea and the powers and duties of its equestrian governors with particular reference to Pilate. This will draw upon Roman and Jewish sources, both literary and epigraphic. The next two chapters examine the references to Pilate in the Jewish writers Philo and Josephus. There are three reasons for taking these authors at this point. Firstly their date. Philo, writing around $41 \mathrm{AD}$, is our earliest literary reference to Pilate whilst Josephus, writing around the mid-seventies and midnineties of the first century AD, is probably later than Mark's gospel but roughly contemporary with the other three. Secondly, the two Jewish writers form a natural pair since a certain similarity in background and apologetic aims leads at times to a similarity in their portrayals of Pilate. Thirdly, the bulk of what we can reconstruct of the historical Pilate is derived from the accounts of Philo and Josephus; by treating their accounts first we will have already formed some picture of the historical man before going on to analyse the way in which he is interpreted by the four evangelists. The remaining four chapters will deal with the portrayal of Pilate in each gospel in turn. 
The material will be arranged slightly differently in the analysis of the Jewish writers than with the Christian ones. This is because the apologetic interests and attitudes towards Rome shown by Philo and Josephus have already been investigated in great detail. Each chapter will therefore begin with a description of these interests and attitudes, and the subsequent discussion of Pilate as a literary character within the works will go on to show how the portrayal of the prefect fits into, and has been influenced by, the general apologetic aims of each work. Each chapter will end with an examination and reconstruction of the historical events behind the rhetoric.

With the gospels, however, the first two steps are reversed. This is largely because there has been less work and less consensus regarding the relation of each gospel writer to the Roman state. After a consideration of the general themes in each evangelist's passion narrative, each chapter will give a description of how each writer presents the prefect as a literary character, asking how a first century reader would have understood and interpreted Pilate's actions. When this has been established each chapter will ask what this portrayal shows about the author's attitude towards the Roman state, symbolized by Pilate, and what kind of community found this useful. After all four Roman trial narratives in the gospels have been analysed, the possible historical events behind them will be discussed.

The conclusion will be in two parts. It should by then be possible to distinguish between the 'historical Pilate', the Roman knight sent by Tiberius to take charge of the province of Judaea, and the many different Pilates of interpretation preserved in the writings of six first century Jewish and Christian authors. 


\section{CHAPTER 1}

\section{The Roman Province of Judaea and its Governor}

\section{The Province}

Reasons for the formation of the Province in $A D 6$

The events which led to the establishment of Judaea as a Roman province go back to the death of Herod I in $4 \mathrm{BC}^{1}$. In the final codicil of his will, the king divided his kingdom between three of his sons: half the territory was to go to Philip and Antipas; the remaining half, including Judaea, was to go to Archelaus. Since Herod I was a vassal king, or rex socius, it lay with Augustus either to ratify the will as it stood or to appoint another successor. Both Archelaus and Antipas journeyed to Rome ${ }^{2}$ : Archelaus anxious to have his succession ratified; Antipas, with the support of Herod's sister Salome, wished to plead for the greater legitimation of an earlier will in which he had been named as successor ${ }^{3}$.

According to Josephus, another delegation appeared in Rome. This consisted of fifty delegates from Judaea, supposedly joined by 8,000 Jews living in the capital, who wanted autonomy, pleading with Augustus to: 'unite their country to Syria and to entrust the administration to governors from among themselves' (Jewish War 2.91). The parallel account in the Antiquities of the Jews, however, asks for governorship by the Roman legates of Syria (17.314). Clearly Josephus would have us believe that the people of Judaea would prefer to be governed by the Romans rather than a successor of Herod. This sentiment was also echoed by the relatives of Archelaus and Antipas who had accompanied them to Rome. Although they now all openly supported Antipas, 'the object that was uppermost in the minds of everyone of them was autonomy under the administration of a Roman governor, but, in default of that, they

\footnotetext{
${ }^{1}$ For more detailed historical surveys of this important period see Schürer, Historv, vol I §§ 16-17, pp 330-427; Smallwood, Jews, pp 105-119; Lémonon, Pilate, pp 33-41; Hoehner, Herod, pp 18-39.

$2^{2}$ Joscphus, The Jewish War 2.14, Antiquities of the Jews 17.219.

${ }^{3}$ War 2.14, Antiq 17.146; for the earlier will see War 1.646, Antiq 17.146. On Herod's six wills see Hochner, Herod, Appendix I, pp 269-76.
} 
preferred to have Antipas for king' (War 2.22) ${ }^{1}$. Support for Roman rule therefore, according to Josephus, was widespread amongst both the people and the Herodian nobility.

Yet Josephus' record can only be accepted with some caution. A central apologetic purpose in both the Jewish War and the Antiquities of the Jews was to show that the troubles leading up to the revolt of $\mathrm{AD} 66$ were initiated by a small rebellious faction and that the people generally acquiesced to Roman rule $^{2}$. This purpose could be served all the better if an initial request for Roman rule actually came from the people themselves. In all probability, there were some who feared that Archelaus might turn out even more tyrannical than his father and to whom direct Roman rule seemed the better prospect, but their numbers and influence were not as great as Josephus would have us believe. This is supported by Augustus' decision not to turn Herod I's territory into a Roman province; a decision which would have been curious, in view of the extra revenues Rome stood to receive, if the population had generally wanted it.

At this stage, Augustus decided to uphold the main points of Herod's final will ${ }^{3}$. Antipas was allotted Galilee and Peraea; Philip was given Batanaea, Trachonitis, Auranitis and certain parts of Zeno ${ }^{4}$ around Panias 5 . Both were given the title 'tetrach', literally the ruler of a fourth part of a kingdom. Salome was declared the mistress of Jamnia, Azotus and Phasaelis and given the palace of Ascalon. The remainder, amounting to half of the kingdom and comprising of Idumaea, Judaea and Samaria, was given to Archelaus with the title 'ethnarch' and the promise that he would be given the title of king if he proved himself worthy. The cities of Caesarea, Samaria, Joppa and Jerusalem were to remain in his control whilst the Greek towns of Gaza, Gadara and Hippos were annexed to Syria. There is some confusion in Josephus over the precise revenue of Archelaus' estate: in War 2.97 it is estimated at 400 talents, in Antiq 17.320 at 600 talents. However, in both works Antipas' estate is valued at 200 talents and Philip's at 100, amounting to a total of 300 talents for their half of the kingdom. Since revenue was calculated roughly in terms of the amount of land possessed, it is reasonable to suppose that the figure of 400 is the most

\footnotetext{
${ }^{1}$ See also Antiq 17.227.

${ }^{2}$ For further details and sccondary litcrature see the following chapter on Josephus.

3 War 2.93-100, Antiq 17.317-320.

4 War 2.95; Zenodonis in Antiq 17.319.

5Or Ituraea, Lk 13.1.
} 
accurate for Archelaus' half of the kingdom ${ }^{1}$. The estates of Salome, valued at 60 talents $^{2}$, were under Archelaus' jurisdiction, bringing the total value of this half of the kingdom to 460 talents.

In AD 6 Augustus was once again forced to consider the government of Archelaus' half of the kingdom ${ }^{3}$. Our main source again is Josephus from whom we learn that both the Jews and the Samaritans under the ethnarch's authority appeared before Caesar to denounce his 'cruelty and tyranny'4. Augustus, angry at the charges, summoned Archelaus to him in Rome, subsequently banishing him to Vienne in Gaul and turning his territory into a Roman province. Yet although Josephus stresses Archelaus' brutality, he records no specific charges, nor does his short description of his reign furnish us with many examples. In the virtual anarchy which reigned in the kingdom after Herod's death, Archelaus is said to have put down a protest at passover with excessive force before going to Rome to seek Augustus' confirmation of his position'. As ethnarch, he deposed two high priests (a practice established by his father) and married unlawfully ${ }^{6}$. This scarcity of evidence may indicate that Josephus' source here, Nicolas of Damascus, ended with the accession of Archelaus 7 . Or, as Martin Goodman suggests, the fall of Archelaus may have been due to dynastic intrigue rather than to Jewish and Samaritan charges of brutality ${ }^{8}$. This is the reason given by Dio and possibly also by Strabo ${ }^{9}$. If the problem was simply Archelaus' brutality, then it would have been possible for Augustus to give his land to Antipas, Philip, or another Herodian; there was no

\footnotetext{
${ }^{1}$ War 2.95, Antiq 17.318 for Antipas; War 2.95, Antiq 17:319 for Philip. Lémonon, Pilate, p106, also agrees with the value of 400 talents. Schuirer, History vol I (rev) gives the revenue from Archelaus' estate as 600 talents without any discussion.

$2_{\text {War } 2.98, \text { Antiq } 17.319 .}$

${ }^{3}$ War 2.111 dates the events to the ninth year of Archelaus' reign. That it was actually the tenth year, as Antiq 17.342 records, seems more likely as this is supported by Dio (55.27) and an allusion to the tenth year of Archelaus' reign in the Life of Josephus 5; see, Jewish War, Locb vol II, p 364, n. b.

${ }^{4}$ Antiq 17.342, also War 2.111.

5 War 2.11-13, Antiq 17.213-218.

${ }^{6}$ Antiq 17.339, 341; Antiq 17.340.

${ }^{7}$ Suggested by Thackeray, Jewish War, Locb vol II, p 364, n a.

${ }^{8}$ Goodman, Ruling, p 39.

${ }^{9}$ Dio 55.27.6, Strabo Geog 16.2.46. The evidence of Strabo is not entirely clear. Speaking of Herod I he writes, 'However, his sons were not successful, but became involved in accusations; and one of them (ie Archelaus) spent the rest of his life in exile, having taken up his abode among the Allobrogian Gauls, whereas the others (ie Antipas and Philip), by much obsequiousness, but with difficulty, found leave to return home, with a tetrachy assigned to each'. The 'accusations' could be from either the inhabitants of Archelaus' ethnarchy (so Josephus) or from the Herodians (so Dio). But the final part of the citation suggests that all three brothers were in Rome at the decisive time when Archelaus was exiled (ie Augustus' second decision and not that of $4 \mathrm{BC}$ ). This may indicate that all three brothers were accusing each other.
} 
compelling reason why Judaea should be turned into a province. Josephus does not even say that the people asked for a Roman governor this time. But if the problem was fighting amongst the Herodians, then that would explain why Augustus felt that it was unwise to entrust the ethnarchy to another Herodian and decided instead to subject it to direct Roman rule. The emperor lost no time in dealing with the ethnarch and formally annexed his territory into the empire. Both the confiscation of Archelaus' property into the imperial treasury and the imposition of direct taxation were financially valuable to Rome ${ }^{1}$.

If it is correct to see dynastic intrigue as the root of the problem confronting Augustus, then any delegations from Jews and Samaritans could have played only a minor role in the affair, if any at all. The views of the people in Archelaus' territory were therefore not a determining factor in the emperor's decision. How then did they respond to direct Roman rule? The violence after Herod's death which was primarily directed at Roman targets, and the troubles which accompanied the inauguration of the province in AD 6 with the imposition of the census taken for taxation purposes, all suggest that pagan rule was not so universally welcomed in Judaea as Josephus would have us believe ${ }^{2}$.

\section{The Imperial Province}

Under Augustus, the empire was divided into two types of provinces: imperial and public ${ }^{3}$. The imperial provinces were not counted as the personal property of the emperor but were administered by him for Rome. Yet the distinction between the two types of provinces was to a large extent illusory. In 23 BC Augustus received maius imperium over the whole empire; thus the public provinces, no less than the imperial ones, ultimately came under his

\footnotetext{
1War 2.111, Antiq 17.344; Goodman, Ruling, p 39.

${ }^{2}$ The principal goal of the unrest after Herod's death seems to have been national independence (War 2.54); for example the clash in War 2.49-50 which led to Roman legionaries plundering the temple; in War 2.51 the Jews rally in greater strength against the Romans. Athrogaeus sets himself up as king in War 2.62, his principal object is to kill Romans and royalists. In 2.63 they surround a Roman century near Emmaus; the Roman Varus sends Gaius to capture and burn Sepphoris and reduce the people to slavery (2.68) and in 2.71 Emmaus is burnt in retaliation for the actions of Athrogaeus. In War 2.75 2,000 are crucified for their part in the revolt. See Hengel, Zealots, pp 325-330. On the census see Hengel, Zealots, pp 127-138; Schürer, History, vol 1 (rev), Excursus 17, pp 399-427.

Josephus characteristically transforms what was probably general unrest in AD 6 by attributing all the troubles to the activities of two men - Judas the Galilean and a Pharisee named Saddok - who together founded a 'fourth philosophy' which directly led to the revolt of AD 66. War 2.118, Antiq 18:3-10, 23-25. Again, see Hengel, Zealots, pp 76-145.

${ }^{3}$ Strabo, Geog 17.3.25. For a list of imperial provinces under Augustus see Stevenson, $C A H$ vol 10 (1st ed), p 211.
} 
control $^{1}$. In general, the more peaceful provinces and those less vulnerable to outside attack were entrusted to the 'people of Rome', that is, were made into public provinces. The emperor took charge of the more turbulent provinces in which military force was necessary 2 . As Dio observed, this arrangement skilfully allowed him to control the army since most of the legions were to be found in his own provinces ${ }^{3}$.

The imperial provinces were themselves of three types ${ }^{4}$. The first two were ruled by legates drawn from the senatorial class, often having served a consulship in the case of the most important ones or a praetorship in the case of those of lesser importance; these had Roman legions at their disposal. Syria belonged to the most important type of imperial province, its legates drawn from men of consular rank ${ }^{5}$. The third and less numerous type of imperial province were those which were least important in terms of expanse and revenue. Often they were territories in which the indigenous population presented particular problems, in which 'owing to a tenacious and individual culture, or lack of it, the strict implementation of ordinary regulations seemed impossible ${ }^{16}$. The governors of these provinces were drawn from the equestrian order and commanded only auxiliary troops ${ }^{7}$. In AD 6 Judaea was transformed into this type of third class imperial province with an equestrian governor at its head ${ }^{8}$.

\section{Relations between Judaea and Syria}

A certain amount of confusion surrounds the precise autonomy of the new province of Judaea. Was it a completely independent province? Or was it, to a greater or lesser degree, under the guidance of the powerful and

\footnotetext{
In the edicts from the senatorial province of Cyrene, both the emperor and the senate appear to take equal responsibility in the task of government; see Stevenson, $C A H$ vol 10 (1st ed), p 212.

${ }^{2}$ Dio 53.12.1-3.

3 Dio 53.12.4.

${ }^{4}$ Strabo 17.840: 'to some, the emperor scnt to take charge men of consular rank, to others men of practorian rank, and to some of equestrian rank-'. Both consuls and praetors were drawn from the same senatorial class.

${ }^{5}$ Quirinius, its governor in AD 6, was, according to Josephus, extremely distinguished and had passed through all the magistracies to the consulship.

${ }^{6}$ Schürer, History, vol I (rev) p 357 .

${ }^{7}$ An exception to this was Egypt where the size and importance of the province made it unwise to entrust it to a senator.

${ }^{8}$ War 2.117, Antiq 18.2. Other such imperial provinces with an equestrian governor at the head were Maurctania Tingitana, Caesariensis and Thrace. See Levick, Government, p 15.
} 
strategically important neighbouring province of Syria? ${ }^{1}$ The direct evidence from Josephus is not particularly helpful since it seems to support both possibilities. In War 2.117 the Jewish writer says 'the territory of Archelaus was now reduced to a province, and Coponius, a Roman of the equestrian order, was sent out as procurator, entrusted by Augustus with full powers. . $\therefore$ This suggests that Judaea was an independent province, there is no indication that the authority of Coponius was in any way limited by the legate of Syria. The longer account in Antiq, however, gives a different impression: 17.355 says, 'now the territory subject to Archelaus was added to (the province) of Syria, and Quirinius . . was sent by Caesar to take a census of property in Syria and to sell the estate of Archelaus'. Book 18 opens with a fuller description of events: Quirinius was sent to Syria as governor and to make an assessment of Syrian property; at the same time Coponius 'was sent along with him to rule over the Jews with full authority'. 'Quirinius also visited Judaea, which had been annexed to Syria, in order to make an assessment of the property of the Jews and to liquidate the estate of Archelaus' (18.1-2). The Roman writer Tacitus twice writes as if Judaea was an independent province: in Hist 5.9, referring to the re-establishment of the province after Agrippa I's reign, he says 'Claudius made Judaea a Roman province'; and in Ann 2.42 he mentions 'the provinces of Syria and Judaea', suggesting that they were distinct. It is not impossible, however, that he is reflecting the situation in his own day (c AD 115-118) when Judaea was ruled by a governor of senatorial standing and was therefore no longer subordinate to the legate of Syria ${ }^{2}$.

These directly opposing statements cannot be resolved without further evidence. Perhaps the best way forward in reconstructing the precise control of Syria over Judaean affairs is by analysing individual cases recorded by Josephus in which the legate intervened in Judaea. J. P. Lémonon has produced such a detailed study and the results are as follows ${ }^{3}$ :

1) Many of the texts which appear to indicate the subordination of the Judaean governor to the Syrian legate are no longer pertinent when set in their broader historical situation. The clearest case in this respect is the intervention of Quirinius at the establishment of Judaea as a Roman province. The legate was responsible for conducting the census in Judaea (Antiq 18.2, 20.102) and

\footnotetext{
${ }^{1}$ An imperial province since $64 / 3 \mathrm{BC}$, Syria was an important element in the defence of the empire against the Parthians to the East and the Nabataeans to the South. Schürer, History, vol I (rev) pp 243-266.

${ }^{2}$ Schürer, History, p 514.

${ }^{3}$ Lémonon, Pilate, pp 60-71.
} 
deposed the High Priest (Antiq 18.26) ${ }^{1}$, but then he seems to have left Judaea and allowed Coponius to exercise his duties as governor unhindered (Antiq 18.29). The legate's intervention at the creation of the province is understandable: such a task would be beyond the capabilities of an equestrian governor. Besides, the taking of a census for taxation assessment could only dissatisfy the local population and the three legions at the disposal of Quirinius would be a useful deterrent against public unrest ${ }^{2}$. Vitellius (AD 35-c39) also only directly intervened in Judaean affairs when the political situation compelled him to. Having deposed Pilate and appointed Marcellus as provisional governor (Antiq 18.89), he granted the Jews certain privileges (18.90), deposed the High Priest and returned to Antioch (18.95). The actions of both Quirinius and Vitellius occurred in extraordinary situations and so do not show the Syrian legates intervening in Judaean affairs in a persistently high-handed way.

2) The intervention of Petronius (who was legate from AD c39-41/2) was due to his being entrusted with a special mandate from the emperor Gaius to erect his statue in the Jerusalem temple (War 2.185, Antiq 18.261, Philo, Leg 207). The operation was presumably beyond the competence of the Judaean governor and again the legions commanded by the legate may have proved useful in a revolt.

3) The Syrian legates could intervene without a special commission when the Judaean governors did not have enough forces to cope with the situation. In Antiq 20.7 Longinus (who was legate from AD 44/5-c50) had come to Jerusalem 'with a large force' out of fear that Fadus' actions might cause a revolt ${ }^{3}$.

4) The Syrian legate acted as an arbitrator between the Judaean governor and the people; both Jews and Samaritans seem to have regarded him

\footnotetext{
$1_{\text {Joscphus gives two descriptions of the deposition of this High Priest, who was named }}$ Joazar. Here he is deposed by Quirinius in AD 6, in Antiq 17.339 he is deposed by Archelaus in AD 4.

${ }^{2}$ These were the VIth Ferrata, Xth Fretensis and IIIrd Gallica. In AD 18 a fourth legion, the XIlth Fulminata, was also added. These four legions were still stationed in Syria during Pilate's governorship (Tacitus, Ann 4.5), Lémonon, Pilate, p 62.

${ }^{3}$ Fadus had demanded that the High Priestly vestments should be in Roman custody, Antiq 20.6-14. This account is probably more reliable than that in 15.406-407. There both Fadus and Longinus want the robes in Roman hands and, after receiving a Jewish envoy, Claudius writes to Vitellius upholding the Jewish cause. Besides confusing the names of the legates, the account in Antiq 15 is brief and anticipatory.
} 
as a higher judicial refuge when their governor was guilty of brutal conduct or unwilling to deal with their problems. A Samaritan delegation complained to Vitellius about Pilate's slaughter of their compatriots (Antiq 18.88) and the legate ordered Pilate to Rome to account for his actions (18.89)1.

The evidence suggests that although Judaea was an independent province the Syrian legate could intervene in times of crisis or be called upon by either the Judaean governor or the people if the need arose. 'Only when there were grounds for fearing unrest, or when other serious difficulties arose, was it within the discretion of the legate of Syria to interfere. He would then take his command in Judaea as the superior' of the governor ${ }^{2}$. His consular standing and control over Roman legions enabled him to do this.

\section{The Duration and Scope of the Province}

Apart from the brief reign of Agrippa I (AD 41-44), Judaea existed as an imperial province from AD 6 until the outbreak of the Jewish revolt in AD 66. In all, fourteen governors were charged with maintaining law and order in the province, of whom Pilate was the fifth, holding office from AD 26-373.

Throughout its sixty year history the borders of the province underwent three changes. Initially, Judaea consisted of Archelaus' territory minus several

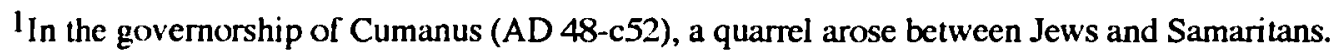
After unsuccessfully appealing several times to Cumanus, both groups appealed to the Syrian legate Quadratus to settle their differences. He decided to send everyone (including the governor) to Rome to be tried before Caesar (War 2.236-244, Antiq 20.118-136). In War 2.280-283 the Jews took advantage of a visit of Gallus to Jerusalem to complain to the legate about the conduct of their governor Florus. On this occasion Florus agreed to greater moderation and Gallus returned to Antioch. Further troubles, however, led to both Florus and the people of his province writing to the legate (War 2.333). Gallus first sent Neopolitanus to report (2.334), then later appeared himself accompanied by a legion and other troops to put down the beginnings of the revolt (War 2.499-500).

${ }^{2}$ Schürer, Hislory, vol I (rev) p 360.

${ }^{3}$ Seven were before Agrippa I: Coponius (AD 6-c9); Ambibulus (or Ambibuchus) (c9-12); Annius Rufus (c12-15); Valerius Gratus (c15-26); Pontius Pilate (26-c37); Marcellus (37); Marullus (37-41). Seven ruled after Agrippa: Cuspius Fadus (44-c46); Tiberius Iulius Alexander (c46-48); Ventidius Cumanus (48-c52); Antonius Felix (c52-c60); Porcius Festus (c60-62); Albinus (62-64); Gessius Florus (64-66). For a detailed description of the governorships of these men, see Schürer, History, vol I (rev) pp 382-398, 455-470.

It is possible that the last two names before Agrippa I, Marcellus and Marullus,

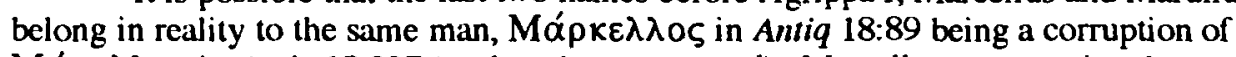

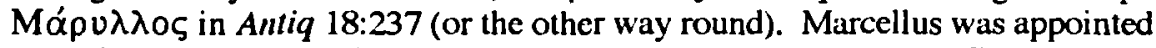
provisionally by the Syrian Icgate Vitellius and may have been confirmed in this post by Caligula. Thus when Joscphus speaks of the emperor sending Marullus, he is using the verb

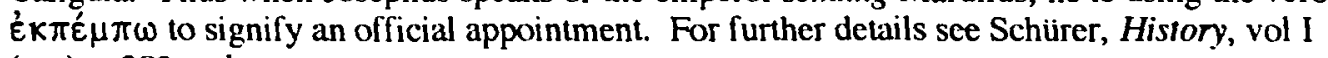
(rev), p 383 and note.
} 
Greek cities. After Agrippa's death in AD 44, the whole of the king's territory reverted to Roman rule; the province was now at its maximum extent, covering not only Archelaus' former territory but also Galilee and Philip's share of the kingdom ${ }^{1}$. In AD 53 the province was reduced in size by the donation of Philip's former territory to Agrippa $11^{2}$; the following year Judaea suffered further loss of territory when part of Galilee, including Tiberias and Tarichaea, and the city of Julias in Panaea along with fourteen neighbouring villages were added to Agrippa II's kingdom ${ }^{3}$.

The province over which Pilate governed belonged to the first phase from AD 6-41, when Judaea was at its smallest. It spread from Idumaea in the south, through Judaea as far as Samaria in the north. Throughout the whole of this time the Greek towns of Gaza, Gadara and Hippos continued under Syrian governorship. The estate of Salome, comprising of Jamnia, Azotus, Phasaelis, Archelais ${ }^{4}$ and the palace of Ascalon, which was formerly supervised by Archelaus, was bequeathed by her on her death in AD 10 to the empress Livia ${ }^{5}$, and, on her death in AD 29, to Tiberius. The estate was administered from AD 10 onwards by imperial financial agents known as 'procurators' resident in Jamnia, rather than by the prefect of Judaea ${ }^{6}$.

To the west the province met the Mediterranean, and, further south, the Greek cities annexed to Syria. Its southern and south-eastern borders joined those of the kingdom of Nabataea7. Due east and north was the territory of Antipas until his deposition in 39. At its north-east and north-west corners Judaea again met the neighbouring province of Syria.

The new province was small, measuring only approximately $160 \mathrm{~km}$ north to south and $70 \mathrm{~km}$ west to east. Yet despite its size its borders

\footnotetext{
${ }^{1}$ This was given to Agrippa on Philip's death, War 2.247.

${ }^{2}$ Antiq 20.138, War 2.247.

${ }^{3}$ Antiq 20.158-159. Several scholars date this last alteration to AD 61 because the last issue of coins by Agrippa II mention an era which began in 61. This however would contradict Josephus $u$ ho links the reduction of territory to Felix's governorship which ended cAD 60 . For a fuller survey of territorial changes throughout the province's history see Lémonon, Pilate, pp 35-36, maps pp 38-41.

${ }^{4}$ This village was built by Archelaus (Antiq 17.340) and was presumably donated to Salome either during the ethnarch's lifetime or at his death since it appears amongst a list of her property in Antiq 18.31 but was not part of her original estate in AD 6 (War 2.98, Antiq 17.321). However, the list of her assets in Antiq 18.31 omits Azotus and it is possible that Josephus has mistakenly written Archelais instead of Azotus.

5War 2.167, Antiq 18.31 .

${ }^{6}$ For example Herrenius Capito the procurator of Jamnia in Antiq 18.158. See Smallwood, Jews, p 158.

7In AD 106 'Arabia belonging to Petra', the former Nabataean kingdom, was made into a Roman province by the legate of Syria acting on the orders of Trajan, Dio 68.14.5. Schuirer, History, vol I (rev), p 585.
} 
encompassed several different groups of people. Predominant was the Judaean Jewish population situated at the centre of the province. To the south were the Idumaean Jews ${ }^{1}$. Both these Jewish groups looked to Jerusalem as their cultural and religious centre. To the north were the Samaritans with Mount Gerizim as their religious centre; feuds between the Samaritans and the Jews were frequent. The province also contained two predominately pagan cities Caesarea and Sebaste - which had been completely rebuilt on the lines of Greek cities by Herod I and contained temples dedicated to Caesar ${ }^{2}$. Both were in the district of Samaria. The frequent riots and troubles between these different peoples, each with their own religious and cultural sensibilities, attests to the difficulties involved in governing such a variety of people in such a confined area.

\section{The Capital of the Province}

Under the Roman governors Judaea had, to a certain degree, two capital cities. The traditional capital, Jerusalem, continued as the focus of Jewish religious life, attracting pilgrims from all over the diaspora during the festivals. The Roman governor, however, resided in Caesarea together with his troops and entourage - including his wife, if he had one - transforming the city into the Roman administrative headquarters ${ }^{3}$. The governor occupied the palace built by Herod which then became known as the 'praetorium'4.

The choice of Caesarea was judicious for three reasons. First, it respected the religious character of Jerusalem. Although many Jews lived in Caesarea, its largely Greek character made it more agreeable to the pagan governor and his troops who could live there without fear of offending Jewish religious sensitivities. Secondly, the city's location by the sea made it a good

\footnotetext{
${ }^{1}$ Despite having been forcibly converted to Judaism by John Hyrcanus at the end of the second century BC, the Idumaeans seem to have regarded themselves as completely Jewish (War 4.270-284). There is also no evidence that the Judaean Jews regarded them as anything other than Jewish; Josephus has Herod I referred to as a 'half-Jew' because of his Idumaean background only once and this is in an extremely polemical speech of his opponent Antigonus to Silo and the Roman army (Antiq 14.403).

2 War 1.403, Antiq 15.296-298 on Sebaste; War 1.408-416, Antiq 15.292-298, 331-341, 16.136-141, Pliny, $N H, 5.14-69$ on Caesarea.

${ }^{3}$ The first evidence for this comes from Pilate's era (War 2.169-174, Antiq 18.55-9), Florus also lived here (War 2.332), as did Felix (Acts 23:23-24) and Festus (Acts 25:1-13). It seems reasonable to suppose that all the governors made Caesarea their capital.
}

${ }^{4}$ Acts 23:35. It was a Roman custom for governors to occupy the palace of the former sovereign, sce Lémonon, Pilate, p 118. 
strategic choice ${ }^{1}$. There was less chance of being surrounded and trapped in a revolt; the harbour built by Herod I made communication with Rome easier; and, in cases of emergency, the Syrian legate could reach Caesarea with greater speed and ease than Jerusalem. Thirdly, although the choice of Caesarea may have appeared to favour the pagan inhabitants of the province, it was neutral ground as far as the three largest ethnic groups - Jews, Idumaeans and Samaritans - were concerned ${ }^{2}$. None could feel that another group commanded more of the governor's attention.

On occasion, the governor moved to Jerusalem: this was especially the case during festivals when the crowds and religious fervour generated at such times could potentially lead to rioting; the presence of the governor with his troops helped to check such outbreaks. Although there is some dispute over whether the governor's Jerusalem residence was the Antonia fortress or Herod's palace, the latter is probably the likeliest. The commanding position of the beautiful palace meant that it was convenient for maintaining law and order $^{3}$. Members of the Herodian family visiting Jerusalem had to stay in the Hasmonaean palace ${ }^{4}$.

\section{The Governor}

\section{Status}

Coponius, the first governor of Judaea, was a man of equestrian rank $\mathbf{k}^{5}$; it is reasonable to suppose that all the other governors of the imperial province also belonged to this rank. The only exception seems to have been the freedman Felix (52-c60); the comments of both Tacitus and Suetonius on his low-birth suggest that the appointment of a freedman was unprecedented,

\footnotetext{
'Suggested by Smallwood, Jews, p 146.

${ }^{2}$ Caesarea was geographically right on the western shore of Samaria but its pagan character meant that it would not be seen as a 'Samaritan town' in the way Jerusalem would be seen as a 'Jewish town'.

${ }^{3}$ In 4 BC the procurator Sabinus lived in Herod's palace (Antiq 17.222); Agrippa's letter in Leg 299 suys that the incident with the shields during Pilate's governorship took place in Herod's palace, in $\$ 306$ this is described as the governor's residence. Florus stayed in the royal palace (War 2.301). For a description of the palace see War 5.177-183, 1.402 and Antiq 15.318. Lémonon gives an account of the archaeological excavations, Pilale, ppl21f. Herod's palace is also favoured by Schürer, History, vol I (rev) pp 361-362 and Smallwood, Jews, $\mathrm{p} 146$.

${ }^{4}$ Agrippa II stayed here during the governorship of Festus, Antiq 20.189-190. This is presumably also where Antipas stayed when he was in Jerusalem for the passover, $L k$ 23:7.

5War 2.117, Antiq 18.2.
} 
thereby indirectly confirming that the others were equestrians ${ }^{1}$. Pilate, then, belonged to the class of equestrians, or Roman knights.

Roman society was strictly hierarchical with the position of members of the various classes formally recognized by the state and marked out by special dress $^{2}$; in the case of equestrians this was a golden ring ${ }^{3}$. The Roman nobility was divided into three classes: the highest were senatorial, then equestrian, then curial. A person's social standing in Roman society was determined by his census valuation, or the value of his property. Thus to merit inclusion in the equestrian order during the principate a man must have property worth at least 400,000 sesterces; if his land was valued at one million sesterces then he could join the senatorial class ${ }^{4}$. Besides being rich, men of the equestrian class had to be of reputable birth; in the time of Tiberius this meant free-birth in at least the two previous generations ${ }^{5}$. Dio described the aristocratic equestrians as men slightly less dignified than senators because they possessed the three virtues of high-birth, wealth and moral excellence in lesser degree 6 . Membership of the equestrian order spread throughout the provinces, providing the social and cultural integration necessary for the empire's durability 7 .

The equestrian order began as an aristocratic cavalry. Under the Republic many prominent equestrians were to be found as publicani, exercising the lucrative task of collecting tribute in the provinces. Although these men held considerable political influence, they had no official governmental position. With Augustus and the empire, this changed. Augustus raised the standing of the $\operatorname{order}^{8}$ and began to appoint equestrians to public and private administrative posts. There were broadly two paths open to men of equestrian standing. One was to become a 'procurator', the emperor's personal agents; they often looked after the emperor's private property and generally saw to financial matters. The other was to undertake a military command which, after some experience, might

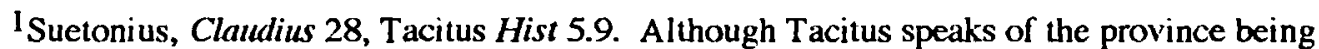
entrusted to 'knights or freedmen', there is no evidence to suggest that any other governor belonged to this class. For further reasons to assume that all the other governors were from the equestrian class see Lémonon, Pilate, p 37. It is possible that Felix, though a manumitted slave, had already joined the equestrian order. Scholars are divided on this question; see Lémonon p 55, n 69 for the literature.

2See Saller 'Roman Class', pp 549-573; also 'Equites' in $O C D$, pp 403-404, by E. Badian (Republic) and F. Millar (Empire).

3 From AD 23 onwards, Millar, 'Equites', p 404.

4pliny $\mathrm{NH} 33.32$.

5 Saller, 'Roman Class', p 565.

${ }^{6}$ Dio Roman History 52.19.2, in a passage where Maecenas is advising Augustus.

7 Josephus mentions men of this rank in Judaea in AD 66, War 2.308.

8 For example, the long disused ceremonial parade, or transvectio, of 15 th July was restored according to Suetonius, Augustus 38-39.
} 
lead to a provincial governorship. The highest of these was the governorship of Egypt. Certain duties in Rome were also undertaken by men of equestrian rank such as the prefect of the imperial bodyguard, known as the 'Praetorian Guard'1. It would be anachronistic, however, to see the opportunities open to equestrians as carefully structured 'careers' in which merits lead to advancement. A man's chances of promotion depended not so much on individual competence as his connections and influences in the imperial court ${ }^{2}$. Equestrians often needed the support of senatorial patrons to secure a post from the emperor. This system also added to the harmony between the two highest classes of nobility; they were bound by bonds of cultural, educational and personal patronage and so both had a shared interest in the preservation of the existing social order.

\section{Length of Governorship}

In general, the Judaean governors ruled from between two and four years. Marcellus, the governor left in charge by Vitellius, governed for one year only whilst Felix lasted approximately eight years (c 52-60) ${ }^{3}$. By far the longest periods of office belong to Gratus, who ruled 11 years (AD 15-26) and Pilate, who ruled between 10 and 11 years (AD 26-Jan 37). It is no coincidence that both these governorships occurred under the principate of Tiberius (14-37). One of the features of Tiberius' provincial administration was that he retained men in office for a long time. He sought to give posts to men of merit and not to supersede them with men who were less able; this was reinforced by his dislike of taking decisions ${ }^{4}$. Josephus mentions the long tenures of governors under Tiberius (Antiq 18.170-173), suggesting that a further motive was to protect provinces from the rapacity of the governors. He writes: 'For it was a law of nature that governors are prone to engage in extortion. When appointments were not permanent, but were for short terms, or liable to be cancelled without notice, the spur to peculation was even greater. If, on the contrary, those appointed kept their posts longer, they would be gorged with their robberies and would by the very bulk of them be more

\footnotetext{
${ }^{1}$ Dio 52.24.2-6. See Ferguson 'Roman Administration', pp 649-665.

${ }^{2}$ Sce Saller, Personal, and Lintott, Imperium, pp 168-174 for fuller details. On equestrian careers generally see Pflaum, Carrières, vols I-III.

${ }^{3}$ If Marcellus is identical with the following governor Marullus, then his governorship lasted five years in total.

${ }^{4}$ Tacitus Ann 1.80, Dio 58.23.5f. Sce Levick, Tiberius, pp 125-147 for a fuller account of Tiberius' provincial policy.
} 
sluggish in pursuit of further gain'1. The long tenures of Gratus and Pilate are therefore perfectly in keeping with this provincial policy.

In deciding who should hold office, Tacitus tells us, Tiberius 'took into view the nobility of a candidate's ancestry, the distinction of his military service, or the brilliance of his civil attainments, and left it sufficiently clear that no better choice had been available' 2 . Yet despite these good intentions, governors often turned out to be less competent than had been hoped and charges of maladministration were frequent ${ }^{3}$. By $4 \mathrm{BC}$ provincials could bring some capital charges against officials ${ }^{4}$. The old Republican laws of lex Julia and repetundae originally did not cover the misconduct of equestrian governors, but by the time of Claudius and Nero, and possibly earlier, these governors could be indicted according to repetundae 5 . A governor could not be tried whilst holding office ${ }^{6}$; he was presumably relieved of his command and subsequently tried in Rome.

\section{The Title of the Governor of Judaea}

The literary evidence for the governor's title is indecisive. Throughout our various sources - Philo, Josephus, the New Testament and Tacitus - the

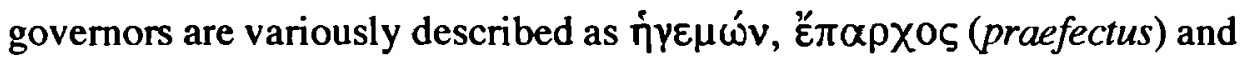

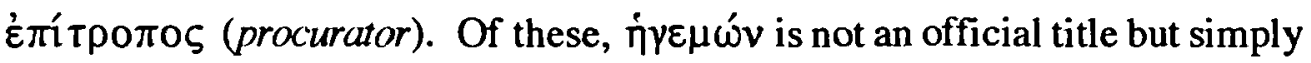
refers to the one at the head, similar to the English 'governor'7. The question,

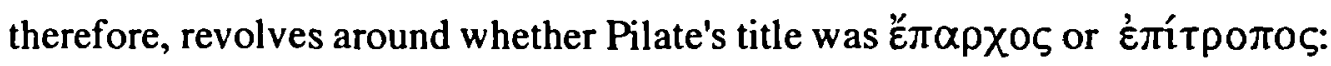
prefect or procurator.

Philo, writing during the reign of Claudius, describes Pilate as

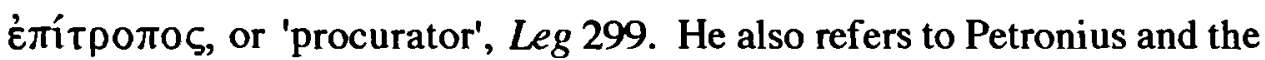

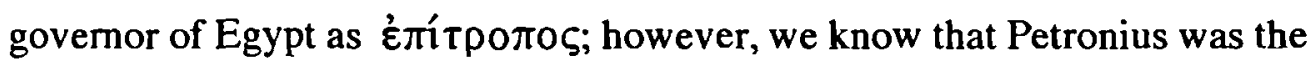

\footnotetext{
${ }^{1}$ Tacitus also notes this concern of Tiberius, Amm 4.6.

${ }^{2}$ Tacitus Ann 4.6; see also the discussion over the character and suitability of Silanus in Ann 3.69.

${ }^{3}$ Brunt, 'Charges', pp 189-223; Levick, Tiberius, p 135. Lucilius Capito, the procurator of Asia was tried in AD 23; C. Silanus, the proconsul of Asia, was convicted of extortion aggravated by violence in AD 22. Tacitus, Ann 3.66f, 4.15.3r, Dio 57.23.4f.

${ }^{4}$ Brunt, 'Charges', p 190 fr citing s.c. Calviscanium 5.9.

5 Brunt, 'Charges', p 198.

${ }^{6}$ Brunt, 'Charges', p 206.

${ }^{7}$ This is used in Acts 23:24,26,33, 24:1,10 (of Felix), 26:30 (of Festus) and several times in Matthew (of Pilate).
} 
legate of Syria and the governor of Egypt was given the title prefect ${ }^{1}$. Thus we cannot be sure that Philo has given us an accurate title for the Judaean governor.

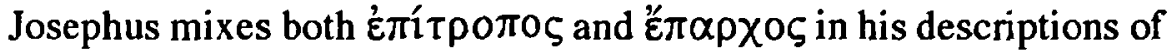
Judaean governors, apparently indiscriminately ${ }^{2}$. In fact, Fadus and Albinus are given both titles ${ }^{3}$. E $\pi \alpha \rho \chi 0 \varsigma$ is more frequently used in Antiq and War 6

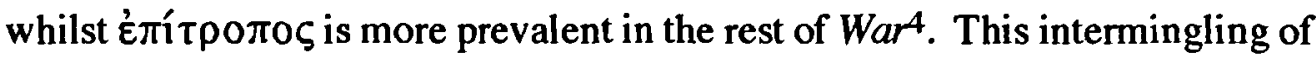
titles is especially surprising since Josephus is writing about conditions in which he took part; he must have been aware of the governors' official title. Unless we are to assume that some, or all, governors held two official titles, which is unlikely, the most probable solution is that Josephus is simply using the two titles in an imprecise non-technical sense ${ }^{5}$. When he describes Pilate as Ėंí reliability, particularly since his two predecessors, Rufus and Gratus have been described as 'prefects'6.

Tacitus refers to both Pilate and Florus as غ̇лí (Ann 15.44, Hist 5.10.1). Again, we would expect the Roman historian to have been aware of the governors' official title but two features cast a shadow over his historical reliability. First, he is writing at the beginning of the second century; the province of Judaea was now governed by a man of senatorial standing and the titles of provincial governors could have been different in the mid first century to what they were in Tacitus' time. Secondly, Ann 12.54, in which Tacitus seems to imply that both Felix and Cumanus acted concurrently as governors, sheds doubt on the historian's awareness of conditions in Judaea.

The New Testament writers never use the title हैm $\alpha \rho \chi 0 \varsigma$, or prefect, although ह̌ $\pi \alpha \rho \chi \varepsilon i ́ \alpha$ is used twice in Acts to describe the region over which Festus governed $(23: 34,25: 1)$. Of the three uses of '̇ंí specific references to the Roman governor of Judaea (Mt 20.8, Lk 8.3, Gal 4.2).

The literary evidence therefore seems indeterminate. But this confusion may be lifted to a large extent by the fact that Claudius introduced certain reforms in his provincial government which included a change in the official

\footnotetext{
${ }^{1}$ Leg 333, 245, 231 (of Vitellius, Petronius' predecessor), 132; In Flaccum 2. See Lémonon, Pilate, $\mathrm{p} 44 \mathrm{f}$ for a fuller discussion.

${ }^{2}$ See the table in Lémonon, Pilate, p 47f,

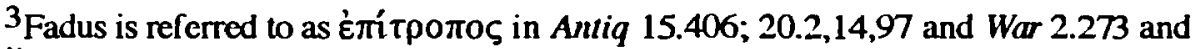
हैं $\alpha \rho \chi 0 \varsigma$ in Antiq 20.197 and War 6.303,305.

${ }^{4}$ Lémonon, Pilate, pp $47 \mathrm{f}$.

5 This is also the conclusion of Lémonon, Pilate, pp 45-48.

${ }^{6}$ Rufus indirectly and Gratus in Antiq 18.33; the first governor Coponius, however, was referred to as 'procurator', War 2.117.
} 
titles of governors ${ }^{1}$. This is supported by epigraphic evidence: before Claudius, or at the beginning of his principate, governors at the head of a group of cities or region are referred to as praefectus; later provincial governors are designated procuratores 2 . In the pre-Claudian principate, the terms prefect and procurator denoted two distinct positions. 'Prefect' was the term applied to the highest officers of equestrian rank who, after a long term of military service, .could be put at the head of an imperial province. 'Procurators' on the other hand were the emperor's private personal assistants, occupying themselves mostly with financial questions. The duties of procurators included raising tribute in an imperial province governed by a legate, attending imperial property within a senatorial province, and managing and administering imperial estates, such as the procurator who looked after Salome's former estate under Julia and Tiberius. Under Claudius, however, 'procurator' appears as the usual title for the governor of an imperial province. Now the title 'procurator' denoted not simply a fiscal agent but a public official taking on the same governmental duties as the former prefect. Only in Egypt was the title 'prefect' retained, possibly indicating the military character of the governor.

This change in the governors' titles under Claudius goes a long way in explaining the confusion of the literary texts. Tacitus is probably using the term anachronistically. Philo, by referring to all governors of Judaea, Syria and Egypt as procurator, may be using the title with its traditional meaning of defender of the interests of the emperor rather than as a technical title. Josephus may be using current terminology, even of earlier prefects, so as not to alienate his readers. The change of title in Judaea does not seem to have altered the duties of the governor; though he had officially changed from prefect to procurator, he still exercised both military govemorship and financial duties. This would explain why Josephus can use both titles since, to some extent, both were an accurate description of the governors's duties, irrespective of what the technical title may have been ${ }^{3}$.

A final piece of evidence which will be discussed in more detail below is the finding of an inscription which refers to Pilate as praefectus. From all this it seems probable that, despite the evidence of the literary texts, all the preClaudian governors of Judaea held the official title of 'prefect'.

\footnotetext{
${ }^{1}$ For fuller descriptions of the information in the next three paragraphs see Jones, 'Procurators', pp 115-125; Sherwin-White, 'Procurator Augusti', pp 11-15; Lémonon, Pilate, pp 50-58; Brunt, 'Procuratorial Jurisdiction', pp 461-489.

${ }^{2}$ Sce Lémonon, Pilate, p 53, nn 61,64 for evidence.

${ }^{3}$ Antiq 18.60 and War 2.175 describe Pilate handling finances. The fact that one man sometimes exercized both functions may have been one of the reasons behind the change, see Lémonon, pp $54 \mathrm{f}$.
} 
Josephus writes of the first prefect: 'Coponius was sent along . . . to rule over the Jews with full authority' (Antiq 18.2). The 'full powers', or

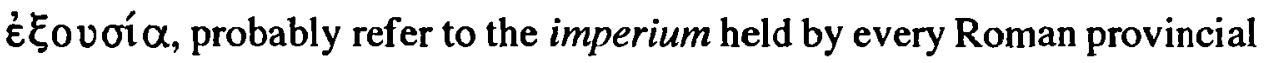
governor ${ }^{1}$. This was the supreme administrative power in the province and included both judicial and military authority.

\section{Capital Jurisdiction}

In War 2.117 Josephus gives a further detail: Coponius was 'entrusted by Augustus with full powers, including the infliction of capital punishment' . The Jewish historian's interest here lies with the Jewish population over whom Coponius was sent to govern. It is clear that the imperium possessed by Coponius allowed him to judge capital matters and, if necessary, to execute provincials without recourse to a higher authority. This accords with the general situation in the empire. A provincial governor needed to be able to prosecute and execute those who endangered public security. For this reason it is reasonable to suppose that Coponius' successors commanded exactly the same powers. Furthermore, Josephus does not mention any change in the governor's powers; his account suggests rather that the authority described in War 2.117 and Antiq 18.2 was the inheritance of every Judaean governor.

Thus all Judaean governors had the power to execute provincials. What is less clear is whether they also had the right to execute Roman citizens who came under their command. By the third century AD, provincial procurators were able to inflict capital punishment on Roman citizens by the ius gladil ${ }^{2}$. Whether this was also the case in the first century is uncertain. A. H. M. Jones suggested that the ius gladii in the first two centuries AD was a power granted to army commanders enabling them to execute soldiers who were Roman citizens serving under their military command, but not Roman citizens under their provincial jurisdiction ${ }^{3}$. When the constitutio Antoniniana bestowed

\footnotetext{
${ }^{1}$ Tacitus, Ann 12.60. A further indication that equestrian governors held imperium at this time is suggested by Lémonon, Pilate, pp 761. Between 6 BC and AD 67, Sardinia was governed by men of equestrian rank (Dio Hist 55.28; Pausanias Description of Greece 7.17.3). Before and after this time, however, it was governed by a pro-consul who did possess imperium. It would be very unlikely if these equestrian governors had lesser powers than the pro-consuls in governing the same province, especially at a time when Augustus was raising the importance of the order in the imperial system.

${ }^{2}$ See Dig 1 18.6.8 (also 1 16.6).

3 Jones, 'I appeal', pp 51-65; also Sherwin-White, Roman, p 10.
} 
citizenship on all provincials in the third century AD, the ius gladii covered all Roman citizens under the jurisdiction of the governor. P. Garnsey, however, would widen the scope of the ius gladii in the early period, suggesting that even by late republican times provincial governors were empowered to execute civilian citizens. But if an accused citizen thought that his case would not obtain a fair hearing in the governor's court he had the right to appeal to Caesar'.

Two pieces of evidence, though not conclusive, do seem to back up Garnsey's case. The first is the trial of Paul, himself probably a Roman citizen $^{2}$, in Acts 25:6-12. In v:9 Festus seems to be offering Paul a Roman trial ${ }^{3}$; there is no indication that the Roman governor was not competent to handle the matter himself. When Paul appeals to Caesar in v:11, Festus confers with his advisers and agrees to his request; again, there is no suggestion that the governor was compelled to send Paul to Rome from the start. Secondly, in War 2.308 Josephus describes the scourging and crucifixion of men of equestrian rank by Florus; his language shows that the action was unprecedented and illegal. But what caused Josephus' outrage may not have been simply the execution of citizens but the fact that as men of equestrian rank they were scourged and crucified, punishments which were inflicted only on provincials. At least from the time of Festus, then, governors seem to have had the right to execute citizens. Again, Josephus' silence on any change in the governors' authority suggests that this was also the case under the earlier governors.

The usual criminal procedure throughout the provinces from Augustus onwards was by cognitio extra ordinem ${ }^{4}$. All the proceedings took place before the governor who took his place on the $\beta \hat{\eta} \mu \alpha$, or judgement seat, situated on the tribunal in front of the people. Accusations were brought by delatores. It was the task of the governor to weigh the allegations and not only to decide on guilt but also to determine the sentence. The defendant was given a chance to speak; but if there was no defence, the governor had no option but to convict 5 . Although the governor was the sole judge, he normally took council with his comites, or consilium, a group of advisors from his entourage.

The supreme judicial competence of the prefect or procurator of Judaea was linked in all probability with the curtailment of the rights of Jewish courts

\footnotetext{
${ }^{1}$ Garnsey, 'Criminal Jurisdiction', pp 51-59.

${ }^{2}$ For arguments in favour of Luke's evidence, see Hengel, Pre-Christian, pp 6-15.

$3 \dot{\varepsilon} \pi$ ' $\dot{\varepsilon} \mu 0 \hat{v}$ supports this reading, although Paul's reply seems to imply that any trial in Jerusalem could not escape Jewish influence.

${ }^{4}$ Sherwin-White, Roman, pp 24-27; Schürer, History, vol I (rev) p 370.

${ }^{5}$ Acts 25.16; Sherwin-White, Roman, p 25.
} 
to execute capital sentences. Although the evidence from Judaea is not entirely conclusive and the precise competence of the highest Jewish courts is still a hotly debated issue ${ }^{1}$, the prevailing scholarly opinion is that Judaean courts did not have the right to carry out a capital sentence. This would have prevented native courts from eliminating the leaders of pro-Roman factions. SherwinWhite argues that the only places which were allowed to retain the right of capital punishment were highly privileged communities known as civitates libertae, 'communities which for past services to the Roman state were made independent of the authority of the Roman magistrates in local administration and enjoyed unrestricted jurisdiction over their own citizens' ${ }^{2}$. No such extraordinary concessions were likely to be found in Judaea. The Jewish authorities may however have been able to convene a court to discuss a capital case and even to reach a verdict, but the final decision seems to have rested with the governor. The gospel accounts of the execution of Jesus of Nazareth back this up, indicating that after a preliminary hearing by a Jewish court the case had to go before the governor.

\section{Military Authority}

The fundamental task of an equestrian governor at the head of a small yet troublesome imperial province was to maintain law and order. By $\mathrm{AD} 18$ four legions were stationed in Syria; it was their task to defend the borders of the empire against the threat from Parthia, Rome's most dangerous enemy, and, if necessary, to intervene in Judaean affairs. The governor of Judaea had only five infantry cohorts and one cavalry regiment, both consisting of auxiliary

\footnotetext{
${ }^{1}$ Evidence generally brought in favour of the Jewish courts having capital powers under the Romans are: the rule concerning Gentile trespassers in the temple (War 6.124-126, Antiq 15.417; also confirmed by an inscription, $R A 23$ (1882) p 220) which may be an extraordinary concession; the execution of any Jew trespassing in the Holy of Holies (Philo, Leg 307) which may be simply hypothetical; the death of James (AD 62, Antiq 220.200-203) which occurred at a time when Judaea had no governor and may have been illegal; and the death of Stephen (Acts 6:12-15, 7:57-59) which may have occurred during the reign of Agrippa I (AD 4l-44). Winter suggests that the penalty of strangulation was introduced after the deprivation of the Jewish right to judge capital matters in AD 70 (Trial, pp 67-74); however, this theory has not been proved.

Arguments in favour of the curtailment of Jewish powers of capital punishment are: the statement of Jn 18:31 (though this could be theologically motivated); the gospel accounts generally; and several rabbinic sources, though it must be admitted that these can only be used with care - Mcgillat Taanit 16, Mekhiltas of R. Ishmael, Simeon ben Yohai on Ex 21:14, jSanh 1,1/18a, jSanh 7,2/24b, Avona Zarah 8b, Sanh 4/a. For a fuller analysis of these rabbinic texts see Lémonon, Pilate, pp 81-90. See more generally Catchpole, Trial, pp 236234; Lohse, TDNT, 7 p 865; Kilpatrick, Trial.

${ }^{2}$ Such as that on Rhodes (which subsequently lost the right after crucifying a Roman citizen), Dio 60.24.4; Sherwin-White, Roman, p 37.
} 
troops, at his disposal ${ }^{1}$. These were generally drawn from non-citizen inhabitants of a province, or occasionally from neighbouring countries. Since Jews were exempt from military service on religious grounds, the Judaean auxiliaries were drawn from only pagan provincials ${ }^{2}$. The Roman governors seem to have inherited the troops of the Herodians drawn predominately from Caesarea and Sebaste ${ }^{3}$. The auxiliaries were organized into cavalry divided into alce (generally 500 men, but sometimes 1,000 ) and infantry divided into centuries from which cohorts of 500 or 1,000 men were formed. From the time of Claudius, men honourably discharged after twenty-five years of service were granted citizenship 4 .

The auxiliary troops were stationed throughout the province. The majority would remain at the governor's military and administrative headquarters in Caesarea (Antiq 18.55); smaller garrisons were scattered throughout the Judaean fortresses ( $W a r 2.408,484 f$ ). One cohort was also permanently posted in the Antonia fortress in Jerusalem (War 5.223f, 244, Acts 21:31). Their number would be increased during festivals by the presence of the governor and a number of Caesarean troops.

The pagan character of these Roman auxiliary troops could on occasion be threatening for the Jewish inhabitants of the province. When trouble broke out between pagans and Jews, it was all too easy for the pagan auxiliaries to show partiality towards their own people 5 . This animosity could also manifest itself in over-brutal treatment of the Jewish population ${ }^{6}$. Although Josephus is doubtlessly exaggerating when he blames these pagan troops for sowing the seeds of the revolt of AD 66 (Antiq 19.366), their one-sidedness and antiJewishness could not have led to stability in the province or Jewish confidence in the imperial forces.

\footnotetext{
'Sce Webster, Imperial Army, pp 142-55; Mavfield, Military, pp 234ff; Spiedel, 'Roman Army', pp 224-232; Schürer, History, vol I (rev), pp 362-367, Vol 2 pp 95f; Lémonon, Pilate, pp 100-105. One of these infantry cohorts may well have been the cohors II Italica civium romanorum volumtariorum referred to in Acts 10; see Hengel, Between, p 203, n 111.

${ }^{2}$ This was a ruling of Julius Caesar, Antiq 14.204, 13.251f.

${ }^{3}$ Antiq 19.365, 20.122, 126; War 2.41, 51-2, 236; see Maxfield, Military, p 234; Spiedel, 'Roman Army', pp 224-232.

${ }^{4}$ Webster, Imperial Army, p 144.

${ }^{5}$ For example the disorders in Caesarea under Felix, War 2.268, Antiq 20.173-178.

${ }^{6}$ For example Antiq 18.62.
} 
A third duty of the Roman governor was to oversee the collection of Roman taxes and, when necessary, to mint coins.

Egyptian papyri witness to the existence of Roman taxes on hundreds of items, from agricultural produce and livestock to irrigation ditches and desert patrols $^{1}$. Portoria, or transit tolls, were also imposed at frontiers, ports and regional boundaries. The heaviest of these Roman taxes however, was the tributum which only inhabitants of the provinces had to pay 2 . Under the Republic this was counted on personal status and so Roman citizens were exempt. But by the first century AD it was primarily a tax on provincial land; thus citizens could no longer claim exemption ${ }^{3}$. The amount of tribute required from each person was worked out by means of a census. The frequency with which the census was held depended on the province and was often irregular ${ }^{4}$. Only one census appears to have been conducted in Judaea, that organized by Quirinius at the formation of the new province in AD 65.

Rome did not have enough officials to see to an efficient collection of taxes and provincials were always at the mercy of corrupt collectors. Under the early principate Rome tended to rely more on local authorities in the collection of taxes rather than the equestrian publicani of the Republican era. The division of the land into toparchies aided the collection. Private agents known as conductores could also bid for the right to collect tribute. However, like the publicani, these men were 'still motivated by the massive profits inherent in the system, and corruption remained the essence of its operation 6 . The tax collectors were legally allowed to demand more from the people than the actual tribute itself 7 . Not surprisingly, many of them were bitterly resented by the people. Supervising these were the emperor's personal financial agents, procurators, assisted by their slaves and freedmen. In small imperial provinces

\footnotetext{
${ }^{1}$ See Shaw, 'Roman Taxation', pp 809r.

${ }^{2}$ Cicero Against Varres 2.3.6.12-13, 2.3.40.91; Tactus Hist 4.74.

${ }^{3}$ Shaw, 'Roman Tasation', p 813.

${ }^{4}$ For example Sicily had a census el eny five years, in Egypt it was even fourteen. See Shan. 'Roman Taxation', p 814.

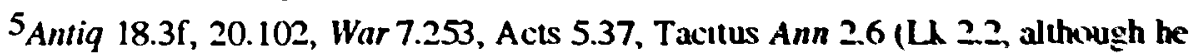
erroneously places it in Herod I's reign. See Schurer, Historv, Vol (rei). Excursus I The Census of Quirinius, Lk 2:1-5' pp 399-427).

6Shaw, 'Roman Taxation', p 820.

${ }^{7}$ For example in N. Africa under the putficani the wax was set at 10-127 of protumaon thut the

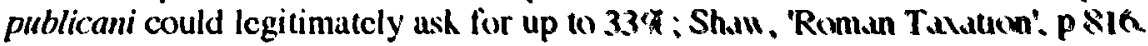


such as Judaea, the governor himself would also fulfil the role of the emperor's procurator. Again, less scrupulous governors could misuse this task to enrich themselves ${ }^{1}$.

The conception behind Roman taxation was of a completely different nature to modern taxes. There was no idea of each person paying towards a general fund from which public services would be provided. The revenues from Judaea went to the public treasury (aerarium) rather than the imperial treasury (fiscus), even though it was an imperial province ${ }^{2}$. When necessary amenities, such as roads or water supplies, were required separate charges were levied ${ }^{3}$.

The minting of gold and silver coinage was the sole prerogative of the emperor, though on exceptional occasions important cities were sometimes given the right to mint silver coins ${ }^{4}$. Under the principate, the striking of bronze/copper coins was permitted throughout the provinces, leading to a rich variety of civic and regional coinage. Following the Hasmonaeans, Herod I and Archelaus, the prefects of Judaea struck coins only of bronze. All these rulers followed the Seleucid monetary system, striking coins with a value of 1 Perutah $($ Jewish $)=1$ dilepton $(\text { Seleucid })^{5}$. The Roman governors may have continued to use the established monetary system in an attempt to avoid arousing hostility amongst the Jews by the introduction of a new one ${ }^{6}$. It was not until the rule of Agrippa I (AD 41-44) that the Roman monetary system was introduced into Judaea? ${ }^{7}$. Coins were struck only when necessary; accordingly

\footnotetext{
1Josephus Antiq 18.172, 176, War 2.273, 292, Philo Leg 199, Tacitus, Ann 4.6.

2 Schürer, History, Vol I (rev) p 372.

${ }^{3}$ Shaw, 'Roman Taxation', p 824.

${ }^{4}$ See Madden, Coins, p 107; Sutherland, 'Coinage', pp 261-263.
}

5 See Maltiel-Gerstenfeld New Catalogue, pp 31-32 and the table on p 34. The connections between the coinage systems can be seen from a comparison of the average weights (2-2.5g) and sizes of the coins; these, however, varied widely since the importance of copper/bronze coins lay in their fractional value, not in their weight as for silver and gold coinage. See Oestreicher, 'Denominations', p 10; also Ya'akov Meshorer, Ancient, Vol II, p 187; Reinach, Jewish Coins, p 41, n 1.

6 Maltiel-Gerstenfeld, 260 Years, p 32.

${ }^{7}$ The location of the procuratorial mint is uncertain. Either Caesarea or Jerusalem are the likcliest possibilities. In the absence of literary or historical proof that these coins were struck in Jerusalem, Hill (CBM (Palestine) p ci) and Meyshan ('Jewish Coinage', p 46) favour Caesarea since the prefect/procurator and his entourage were stationed there. Meshorer, Anciem, p 186, however, favours Jerusalem for two reasons: 1) this was the former capital and location of Archclaus' mint, and 2) an uncirculated 'mint-piece' was found in Jerusalem; it was one of the coins issued by Pontius Pilate with the strips from the mould still attached. (Now in the collection of the Institute of Archaeology, Hebrew University of Jerusalem). Kadman, too, favours Jerusalem ('Development', p 100, n 2). 
only five prefects/procurators issued coinage (Coponius, Aristobulus, Gratus, Pilate and Felix) ${ }^{1}$.

\section{The Governor and his Relations to the High Priest and} Aristocracy

The highest Jewish office was that of the High Priest; Leg 278 gives it a position higher than kingship because it was primarily concerned with the service of God. But because religion permeated every aspect of Jewish life, the High Priest was also the highest national leader. In pre-Maccabean days the office of High Priest was for life and hereditary, its members were believed to belong to an uninterrupted succession of Zadokites going back to Aaron. With the Hasmonaean dynasty a new high priestly family usurped the position, combining it with military leadership, but the office remained hereditary and for life. Herod I, however, aware of the potential rivalry of a strong High Priest, took it upon himself to appoint and depose High Priests at will, generally favouring men from less well-known Zadokite backgrounds as they posed the least threat. The Romans too recognized the political importance of the position and exercised their control by appointing the High Priests from 6-41. Only men who could be relied on to pursue an actively pro-Roman policy would be chosen ${ }^{2}$. Before the reign of Agrippa, this generally fell within the competence of the Judaean prefect ${ }^{3}$. In the period AD 6-41, the High Priesthood was almost entirely in the hands of Ananus b. Sethi and his family (Antiq 20.198), an obscure priestly family ${ }^{4}$. Ananus, his son-in-law Caiaphas, and three of his sons were appointed to the office; the tenures of the two men from other families were brief5. On his accession in AD 41, Agrippa restored the High Priesthood to the pro-Herodian family of Boethus. From this time on, the

\footnotetext{
${ }^{1}$ For fuller details see Hill, $C B M$ (Palestine).

2Smallwood, 'High Priests', p 22.

3 Only in two exceptional cases did the legate of Syria intervene: Antiq 18.26 when Quirinius replaced Joazar by Ananus, and Antiq 18.90-95 when Vitellius dismissed Caiaphas and replaced him with Jonathan.

${ }^{4}$ Goodman, Ruling, p 44. For some of the conjectural origins of Ananus b. Sethi and his family see Stern, CRINT, vol 2, p 606.

${ }^{5}$ Smallwood, 'High Priests', pp 14-16.
} 
appointment of the High Priesthood passed completely into Herodian hands: first to Agrippa I, then Herod of Chalcis and later Agrippa II ${ }^{1}$.

A clear indication of Roman control over the supreme Jewish authority was that the High Priestly vestments remained in Roman custody until AD 372 . It was the function of the High Priest to stand before the people at the feasts as a representative of God in order to expiate the sins of the community. This ability was conferred upon him by wearing the vestment and eight ornaments, each one of which had expiatory virtue. Following Herodian practice, the Romans took charge of these vestments, allowing them to be restored to the High Priest seven days before each festival for purification ${ }^{3}$. That such holy vestments, essential to the religious life of the community, should be in pagan hands would have been offensive to Jewish piety and served as a permanent reminder of their subjugation to Rome ${ }^{4}$.

After Herodian rule, Josephus writes, the Jewish 'constitution became an aristocracy, and the high priests were entrusted with the leadership of the nation' (Antiq 20.251). Although the prefect was responsible for maintaining law and order and he represented the highest judicial authority, it was the Jewish High Priest and aristocracy in Jerusalem who handled the day-to-day administration and thus the real government of the nation. This is completely in accordance with general Roman provincial policy which left as much local administration as possible in the hands of the native authorities ${ }^{5}$. The scarcity of Roman officials in the provinces meant that efficient government had to rely to a great extent upon the co-operation of local authorities. The Romans expected them to act as mediators, representing the feelings of the people to the governor and the expectations of the governor to the people 6 . They acted as representatives of their community and endeavoured to uphold the status quo ${ }^{7}$.

\footnotetext{
${ }^{1}$ Antiq 19.297, 316; 20.15, 103 (Herod of Chalcis); 20.104, 213 (Agrippa II). Josephus records that this was the result of a Jewish petition (Antiq 15.403-405, 18.90-95, 20:6-16).

${ }^{2}$ They were restored by Vitellius, the legate of Syria, after writing to Tiberius (Antiq 15.405, 18.90-95)

${ }^{3}$ Antiq 18.90-95. On the High Priest and his vestments see Sanders, Judaism, pp 99ff, 319327.

${ }^{4}$ The dispute flared up again in the governorship of Fadus who wanted to take the vestments back into Roman custody (Antiq 20.6); the matter was referred to Claudius who decided in favour of Jewish custody in AD 45 (Antiq 20.6-16).

5 See for example $O C D, \mathrm{p} 724$, Schurer, Hislory, vol I (rev) p 376.

${ }^{6}$ For example Joazar the High Priest acted in this capacity when he persuaded the people to acquiesce to the census of AD 6 (Antiq 18.3); Petronius summoned the aristocracy, expecting them to act as intermediaries, when he was charged with the difficult task of erecting Gaius' statue in the temple (War 2.199); the Jewish magistrates, the chief priest and notables act as spokesmen before Cumanus and the Syrian legate Quadratus (War 2.237f, 240).

${ }^{7}$ McLaren, Power, comes to these conclusions after carefully examining individual incidents under Roman rule. Sanders also examines the role of High Priests and aristocrats at this
} 


\section{Pontius Pilate}

As governor from AD 26-371, Pilate ruled over the imperial province of Judaea in its first phase under direct Roman governorship, ie 6-41. Like Coponius, he was probably a member of the aristocratic equestrian class. $\mathrm{He}$ would have been a man of wealth and, presumably, respectable birth. Men of equestrian standing had three names. Pilate was his surname while Pontius denoted the gens or family from which he was descended. His first name is unknown. Of his life prior to arriving in Judaea we know nothing. It is likely, however, that he would have had experience as a military commander and, on the basis of this, secured the post of provincial governor through connections with Tiberius.

period with similar conclusions to McLaren, Judaism, pp 322-338. Goodman, however, has a much more negative view of the standing and influence of the aristocracy, in both the eyes of the Jewish people and the Roman governors, Ruling, pp 34-49. He argues that in AD 6 the Romans found no long-standing élite on whose power to command public respect amongst the people they could rely. Fearing political rivals, Herod I had systematically eliminated all the old Hasmonaean aristocracy throughout his rule, replacing them with his own favourites (War 1.358, Antiq 14.175, 15.6). His continual interference with the High Priesthood, in

Goodman's view, downgraded the office. This can find support in the demand of the people on Archelaus' accession that Herod's favourites should be punished and the High Priest removed in favour of a more pious man (War 2.7, Antiq 17.2070). Jonathan the High Priest was also the first of the terrorist Sicarii's victims (War 2.256; though Antiq 20.160-166 suggests Felix was behind the murder). Goodman sees divisions amongst members of the ruling class, particularly the decision of some members to cut ties with Rome and to seek power themselves, as a determining factor in the revolt. Yet although the Herodian and Roman appointments probably downgraded the High Priesthood to some extent, Goodman's view of the loss of public respect in both priestly and lay hierarchies is perhaps a little too negative: the High Priest still exercised the all-important task of expiating the sins of the community; during the revolt the aristocrats were Jewish leaders, suggesting that their influence and respect amongst the people was greater than Goodman will allow. See Sanders, Judaism, pp 323327, War 4.319-325, 2.566, Life 29, Antiq 20.196.

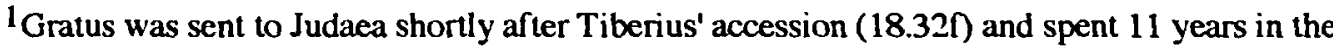
province (18.35). Although the date is not certain, this evidence points to $\mathrm{CAD} 25 / 6$. Pilate was dismissed just before Tiberius' death in March 37 after goveming for 10 years (Antiq 18.89), suggesting a date of CAD 26.

Following Eisler, Messiah, pp 13-20, Schwartz suggests that Pilate came to office in AD 19. 'Pilate's Appointment', pp 182-201. The events in Rome related in Antiq concerning Isis worship and Jewish embezzlers which culminated in the expulsion of the Jews in AD 19 (Suet Tiberius 36, Dio 57.18.5a, Tacitus Ann 2.85) are therefore in the correct chronological order(Antiq 18.65-80, 81-84). Gratus, Schwartz believes, was deposed in AD 19 after the Jews complained about excessive taxation (Tacitus $A n n$ 2.42.5) and possibly also his habit of apparently changing High Priest every year. Schwartz's case sounds plausible but has to assume that the lengths of office specifically given in Josephus for Gratus and Pilate are later Christian forgeries. Like Eisler, Schwartz believes that these passages were forged in an attempt to counter the official report of the trial and crucifixion of Jesus sent by Pilate to Tiberius and circulated during the principate of Maximin Daia in 311. This document set the execution at AD 21. All copies of Josephus were supposedly tampered with to prove that Pilate was not in office until AD 26, thus showing the official document to be a hoax. However, it is difficult to see how every copy of Antiq could have been altered at such a late date. Furthermore, if Eisler's reconstruction is correct, then the Acta Pilati in circulation were known to be the genuine records of Jesus' Roman trial which must therefore have occurred at the incredibly early date of AD 21. 
Pilate is the only provincial governor whose title is known with certainty. In 1961 a block of limestone containing an inscription was found during the excavations at Caesarea Maritima. The stone had been moved from its original position and reused as part of a staircase in one of the many later alterations to the amphitheatre originally built by Herod I. The block had been trimmed down to correspond to its new position; half of the inscription has disappeared entirely and some of what remains is mutilated. The following words are still legible:

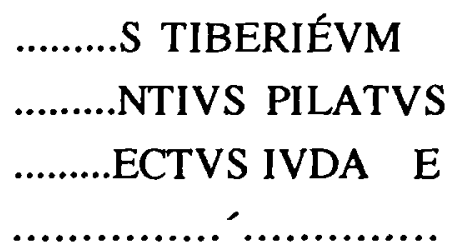

Although complete reconstructions of the inscription are tentative and extremely hypothetical in nature, and we have no idea what was referred to by TIBERIÉVM, except that it was probably some kind of building1, two things are clear. One is that the second line refers to Pontius Pilate, presumably giving his first name in the mutilated left section; secondly, the third line gives his official title which, in all probability, is to be reconstructed as 'Praefectus Indaeae' .

In common with other prefects and later procurators, Pilate's principal duty was the maintenance of law and order in Judaea. For this purpose he held the supreme power or imperium in the province. He was the highest judicial authority to whom all capital cases had to be referred. His headquarters were in Caesarea where most of the pagan auxiliary troops at his disposal were also stationed. Although technically a 'prefect', Pilate would also have acted as a procurator in that he was ultimately responsible for overseeing the collection of taxes.

Again, in common with other governors and general Roman policy, Pilate was dependent to a large extent on the maintenance of the status quo by

\footnotetext{
${ }^{1}$ For a full discussion of the solutions proposed by A. Frova, A. Degassi and E. Weber see Lémonon, Pilate, pp 26-29. Lémonon himself suggests that the small size of the block would indicate that it is not a dedication but simply a brief inscription recording the name of the building. He therefore suggests a simple fécit for the final line rather than the dédit or dédicavit proposed by other scholars.

Several scholars have assumed that the Tiberiéum was a temple dedicated to the emperor. Although Tiberius appears not to have encouraged his own cult, epigraphic evidence affirms its existence (eg ILS 162, 3.474, 933, 4.454, cited by Lémonon, p 31 n 37). However, the mutilated state of the inscription means that we cannot be sure to what kind of building it referred. The briefness of the inscription, the lack of any formal addressee and the fact that Tiberiéum' seems to presuppose a building dedicated to Tiberius, makes it perhaps more likely that Pilate had a secular building erected and dedicated to the empcror. Precisely what kind of building this was is unknown. See Lémonon, Pilate, pp 29-32.
} 
native authorities, in particular, the High Priest ${ }^{1}$. In the time of Pilate, both the appointment of the High Priest and the custody of the vestments lay with the Roman prefect. Whilst his predecessor, Gratus, had no less than four changes of High Priest in his eleven year governorship, Pilate made no change to the incumbent of the High Priesthood ${ }^{2}$. This was presumably not out of any wish to respect Jewish sensitivities but rather because he found in Gratus' last appointee, Caiaphas, a man who could be relied on to support Roman interests and who could command some respect amongst the people ${ }^{3}$.

Caiaphas outlasted Pilate, retaining his office into the first few months of Marcellus' prefectship. According to Antiq 18.90-954, Vitellius, the legate of Syria, visited Jerusalem and, after allowing the people to retain the High Priestly vestments in Jewish hands, he deposed Caiaphas in favour of Jonathan, a son of Ananus. Josephus gives no reasons for Caiaphas' deposition. It is often assumed that he was seen as a pro-Roman collaborator, a hench-man of Pilate, who was for that reason disliked by the populace 5 . Vitellius' actions are therefore seen as a series of gestures indicating Roman goodwill: he remits certain taxes (Antiq18.90), allows the vestments to be in Jewish custody (18.90-95), and finally deposes an unpopular High Priest. Yet several features in the story suggest that this was not the case. After being received in magnificent fashion, Vitellius seems anxious to please the Jews and remits the taxes on agricultural produce. Next Josephus says that he agreed to

\footnotetext{
${ }^{1}$ The accounts of events in Pilate's government given by Josephus give the impression that the Jews acted en masse in opposing Pilate (Wor 2.170f, 174, 175; Antiq 18.57-59, 60-62). The High Priest and aristocrats are never seen as intercessors or negotiators. This how ever is probably due to Josephus' apologetic bias; he wants to show the Jewish people acting in one body in opposing anyone who threatens their laws and religion. See McLaren, Power, p 87. Philo, however, refers to the Jews choosing spokesmen to represent them to Pilate (Leg 300 , though Agrippa may have enhanced the role of the four Herodians). The NT accounts of the trial of Jesus also suggest a certain amount of negotiation between Plate and the chief priests. ${ }^{2}$ Gratus' governorship is described briefly in Antiq 18.33-35. He appointed Ishmael the son of Phabi, Eleazar son of the High Priest Ananus, Simon the son of Camith, and, in AD 18/19, Joseph, called Caiaphas. The latter was the son-in-law of Ananus (or Annas) according to John 18:33.

${ }^{3}$ On the basis of the 'bribes' in Leg 302, Catchpole suggests that Caiaphas' long tenure of the office may have been due to his ability to pay for it, Trial, p 249; this however seems to be reading rather a lot into a heavily apologetic section. Eisler, Messiah, cites Jerome (Ed Vallarsi 7.223) who said that Caiaphas bought the office for a year from Antipas (p 18, n 1); since Jerome claimed to derive his information from Josephus, Eisler suggests that part of the text of Antiq 18.35 containing this information is missing ( $p$ 8). It is not impossible, however, that Caiaphas did offer the governors some monetary reward for the office, or ev en that Ananus offered Pilate financial inducements to keep his son-in-law in the office until his own son was old enough to take over.
}

${ }^{4}$ On Vitellius' journeys to Jerusalem see Smallwood, Jews, pp 172-173 (and 'Date', pp 12-21) and, less likely, Hoehner, Herod, pp 313-316 (Appendir 8).

${ }^{5}$ Sce for example Smallwood, Jews, who remarks that Caiaphas was likely to be unpopular as a tool of Pilate', p 172. 
allow the vestments to remain in the temple, suggesting that the people had previously asked this favour of him. In fact, such a request is found in Antiq 15.405 where Vitellius, not having the power to make such an extensive change in the running of Judaea, agrees to write to Tiberius and subsequently receives permission. Then, 'after he had bestowed these benefits on the nation', he deposed Caiaphas; thus there is no indication that the removal of Caiaphas was regarded as a benefit by the people. It seems therefore that the deposition of Caiaphas was in the protection of Roman interests and was a consequence of the High Priestly vestments being handed over to the Jews. The reason for this is not difficult to find. Vitellius had previously sent a new provisional governor, Marcellus, to take charge of Judaea; he probably did not have the same powers as other governors ${ }^{1}$. The granting of the vestments was a large concession to the Jewish nation, one which would undoubtedly have raised the standing of the High Priest in that the robes and ornaments vital to his function as expiator of the community's sins were no longer in pagan custody. It could have seemed politically dangerous to Vitellius to allow a man who had occupied the position of High Priest for almost twenty years to continue with increased status at a time when the Roman governorship of the province was uncertain. The safest political move was therefore to depose Caiaphas and to replace him with another man from the family of Ananus. Thus Caiaphas' removal may not have been because of popular distrust of his pro-Roman collaboration but because his long period of office and respect in the community could have potentially been a threat to Roman security.

One more factor would have necessitated a stable government in Judaea: this was the situation in Syria throughout the early years of Pilate's prefectship. During Pilate's governorship, Syria had three successive legates. The first was L. Aelius Lamia. His term of office ended in AD 32 and, although we do not know the exact year of his appointment, he was probably already the legate when Pilate came to Judaea in AD 26 2 . He was followed by L. Pomponius Flaccus from AD 32-c 35. Third was $L$. Vitellius from 35-c 39, the legate responsible for Pilate's eventual deposition. Of these three legates, the tenure of the first, Lamia, deserves special attention. Both Suetonius and Tacitus testify that Tiberius gave provinces to men whom he never allowed to leave

\footnotetext{
${ }^{1}$ Smallwood, Jews, is probably correct in thinking that he did not have full authority; as legate of Syria, Vitcllius did not have the authority to appoint a permanent prefect of Judaea. ${ }^{2}$ Schürer, History, vol I (rev) p 261. For further information on all three legates see Schürer pp 261-263.
} 
Rome'. Suetonius notes, 'he had assigned provinces to one or two ex-consuls, of whom he did not dare to lose sight, but he detained them at Rome and finally appointed their successors several years later without them having left the city. In the meantime they retained their titles, and he even continued to assign them numerous commissions to execute through their deputies and assistants'. Both writers suggest that Tiberius' motivation was fear that eminent men should be out of his sight, but it may be that Tiberius was in fact trying out a form of centralized government whereby provinces were governed in the capital ${ }^{2}$. Lamia appears to have been one of these men $^{3}$. The two subsequent legates, however, both governed their province from Antioch ${ }^{4}$.

The implication of all this is that for the first six years of Pilate's governorship there was no Syrian legate in residence acting as a general overseer and mediator in Judaean affairs. Although Lamia conducted his official duties from Rome, the problems of long-distance communication would inevitably mean that he lost a certain degree of contact with his province. The distance would also mean that it was much more difficult for embassies from Judaea to contact the legate. Exactly what powers the Syrian 'deputies and assistants' would have had in dealing with Judaean affairs is uncertain 5 . From Pilate's point of view, the absence of the Legate was not entirely advantageous. It could be argued that he might recklessly misgovern the province, misusing the fact that the people had no strong advocate in Syria. Possibly some of this was true, yet if his behaviour had been completely provocative towards the people we would expect them to have immediately complained to Flaccus on his arrival in AD 32. As far as we know, this was not the case ${ }^{6}$. It is more likely that the absence of the governor presented difficulties for Pilate. Unlike his predecessors, he could not rely upon the immediate support of the legions in case of unrest. This would mean that any potential uprising had to be put down quickly before it could escalate.

The passover amnesty, or privilegium paschale, recorded by the gospels may also show a desire by Pilate to placate the people and to try and avoid

\footnotetext{
${ }^{1}$ Tacitus, Ann 1.80, Suctonius Tiberius 63 ( $\$ 41$ probably also implies that the governor $\mathrm{w}$ as not in his province).

${ }^{2}$ See Levick Tiberius, p 125; Stcvenson, CAH, p 649.

${ }^{3}$ Tacitus, Ann 6.27.

${ }^{4}$ On Vitellius' governorship see Tacitus Ann 6.32.

5Possibly the commanding officer Pacurius (Ann 2.79, Seneca Epist Mor 12.8-9) acted as one of Lamia's deputies (Stevenson, $C A H, \mathrm{p}$ 649); though what powers he would have had or er the Judaean governor and to intervene in Judaea are unknow $n$.

${ }^{6}$ Given Josephus' apologetic interest in showing that one of the factors leading to the Jewish revolt was continued misgovernment by the Roman governors, he would surely have reconded such an event had he known of it.
} 
unrest. There are however two problems with seeing this as a regular 'custom'. The first is that there is no agreement within the gospels themselves over the precise nature and scope of the release. Matthew and Mark both suggest that it was a custom of the Roman governor (or his predecessors) and locate it simply at 'the festival season', though clearly the passover is implied (Mk 15:6, Mt 27:15); the reference in Luke 23:17 is almost certainly secondary and suggests that Pilate was obliged to release a prisoner; Jn 18:39, however, implies that it was a Jewish custom and locates the amnesty at passover, in this case it may have been taken over from Hasmonaean or Herodian times. Secondly, there are no extra-biblical records of this custom whatsoever ${ }^{1}$. There are, however, certain references to amnesties elsewhere in the Roman world. A papyrus from AD 85 records the release of Phibion by G. Septimus Vegetus; an Ephesian inscription from AD 441 similarly records the release of a prisoner ${ }^{2}$. It is not impossible that the release of Barabbas, at about the same time as Jesus' trial, was a single act of clemency rather than an act associated with a regular custom $^{3}$. Pilate, and possibly other governors, may have occasionally released lesser criminals as a gesture of Roman goodwill, especially at such potentially volatile situations as Jewish festivals. The chief priests may again have played the role of negotiators in securing the release.

Finally, besides the inscription already referred to, we possess one further direct archaeological link with Pilate - his coins. Although the coins issued by the Roman prefects/procurators were generally of a high workmanship, dating Pilate's coins is made particularly difficult by the fact that several specimens are crudely struck. The designs, inscriptions and particularly the dates on these coins are poor and difficult to decipher. However, scholars are generally agreed that Pilate struck coins with the following three dates and designs:

\section{a) Obverse}

3 ears of barley; the central upright the others drooping, tied together by the stalks with 2 horizontal bands.

\section{Reverse}

What looks like a simpulum

with upright handle. TIBEPIOY KAICAPOC

\footnotetext{
${ }^{1}$ M.Pesahim 8.6a is of ten cited in support of this custom but the text seems to refer rather to someone whose prison sentence ends at passover and the arrangements to be made in his case for the feast. For a fuller discussion see Winter, Trial (rev), pp 131-133; also Chaval, 'Releasing', pp 273-278 followed by Blinzler, Trial, Excursus X, pp 218-221.

2Papyrus Forentinus 61. See Deissmann, Light, p 269, n 7. In neither case, however, do we know how far the legal proceedings had gone, nor the exact charges.

${ }^{3}$ Gnilka, Evangelium, p 301; Lührmann, Markusevangelium, p 256.
} 
b) Lituus with crook facing right TIBEPIOY KAICAPOC
Wreath with berries, tied below

with ' $\mathrm{X}$ '

Date: LIZ (year 17) AD 30/313 c) As above
As above but

Date: LlH (year 18) AD 31/24

Pilate seems to have struck coins in only three successive years: AD 29/30,30/1 and $31 / 2$, corresponding to the fourth, fifth and sixth years of his rule. The coins follow the usual practice for coins struck in Judaea in that they contain no portrait of the emperor but only a Greek inscription recording his name. One side of each of the coins contains a purely Jewish representation: the three ears of barley and the wreath. The other sides each contain a distinctively pagan symbol connected with the Roman cult: the simpulum and the lituus. Whilst both these symbols were used in Roman coinage generally, Pilate was the first to use them on Judaean coins. Yet Pilate was not the first to deviate from purely Jewish designs on Judaean coinage 5 . Of the Hasmonaeans, Alexander Jannaeus appears to have gone furthest in borrowing from Seleucid designs. Under Herod I and his son Archelaus the coins show more numerous symbols of a pagan origin, in particular the tripod with lebes, the caduceus, aphlaston and the eagle. Although the early prefects used only Jewish designs, Gratus seems to have experimented in his first few years with pagan representations such as the caduceus and kantharos. The use of these symbols may have stemmed from a desire to emphasize important features from both Judaism and the Roman cult, such as wine offerings.

\footnotetext{
1 The following descriptions are based on Hill, CBM (Palestine), pp 257-260.

2Hill, CBM (Palestinc), pp 257-258, nos 54-68; Madden, Coins, p 182, no 12; Reifenberg, Anciemt, p 56, no 131; Maltiel-Gerstenfeld, New Catalogue, p 107, no 239; Kindler, Coins, p 102, no 156; Meshorer, Ancient, p 283, nos 21-22.

3 Hill, CBM (Palestine), pp 258-259, nos 69-77; Madden, Coins, p 182, no 14; Reifenberg, Ancient, p 56, no 132; Malticl-Gerstenfeld, New Catalogue, p 108, no 241; Kindler, Coins, p 103, no 158; Mcshorer, Ancient, p 283, no 23.

${ }^{4}$ Hill, CBM (Palestine), pp 259-260, nos 78-82; Madden, Coins, p 183, no 15; Reifenberg, Ancient, p 56, no 133; Kindler, Coins, p 103, no 159; Meshorer, Ancient, p 283, no 24.

5 See my article The Coins of Pontius Pilate: Part of an Attempt to Provoke the People or to Integrate them into the Empire?' due to be published in JSJ, September 1996.
} 
Given the history of pagan designs throughout Judaean coinage, particularly from Herod and Gratus, Pilate's coins do not seem to be deliberately offensive. Had he wished to antagonize his Jewish subjects or introduce the imperial cult, he would surely have struck coins bearing images of the emperor or other pagan gods/goddesses rather than simply cultic vessels. The fact that neither Marcellus or Marullus appear to have seen any necessity to issue coins with a new design and Agrippa I was presumably content to use Pilate's coins until issuing his own in 42/3 suggests that these coins were not unduly offensive. Furthermore, the fact that one side of the coins always bears a purely Jewish design may suggest that Pilate deliberately depicted both Jewish and Roman symbols in an attempt to continue the attempt of Herod the Great and his successors to integrate Judaea further into the empire ${ }^{1}$. The use of pagan vessels may show a certain lack of sensitivity but hardly reflects a deliberate attempt at being offensive.

Pilate's coins have often been used to substantiate a link between the prefect and Sejanus, the allegedly anti-Jewish commander of the Praetorian Guard and a man with considerable influence over Tiberius ${ }^{2}$. E. Stauffer suggested that as part of a world-wide action against the Jews Sejanus ordered Pilate in AD 29 to put provocative pagan symbols on his coins. The intention was to rouse the Jews to open rebellion which was then to be brutally crushed; Sejanus' fall in AD 31, however, prevented the final realization of these intentions ${ }^{3}$. Smallwood, too, notes that Pilate's last issue of coinage (AD 31/2) corresponds to the year of Sejanus' death, suggesting that with the removal of Sejanus Pilate did not dare to issue any more offensive coins ${ }^{4}$.

Several points from the preceding discussion, however, go against such a direct link between Pilate and Sejanus. First, pagan symbols, although relatively rare, had already been used on Jewish coins. Intervention by Sejanus is not necessary to explain Pilate's use of such designs. Secondly, the simpulum, as a symbol of the Pontifex, appears to have been more offensive than the lituus. If Pilate were acting according to an anti-Jewish plan of Sejanus, we would expect the symbols to become more and more provocative; as it is, the more provocative symbol gave way within a year to the lituus which

\footnotetext{
1 See Hengel, 'Hellenization' of Judaea, p 41.

2 Only Philo, Legatio 159-160 and the beginning of In Flaccum (followed by Eusebius, Ex Hist ii.5.5), records Sejanus anti-Jewish policy. Whilst Suetonius (Tiberius 36.1), Tacitus (Annals 2.85.5) and Dio (lvii.18.5a) write of an expulsion of Jews from Rome in AD 19, they do not link it to Sejanus. Unfortunately. Philo's account cannot be compared with that of Tacitus since his account of AD 30/1 in the Annals has not survived.

3 Jerusalem, pp 16-18.

${ }^{4}$ Smallwood, Jews, p 167.
} 
was then used without change the following year. Thirdly, the simplest way to provoke the Jews, and to bring Judaea in line with other Roman provinces would have been to put an image of the emperor on the coins; this Pilate did not do. Fourthly, the argument that Pilate issued no more coins after Sejanus' death ignores the fact that the coins would have been used for several years after the date on which they were issued. Thus coins struck in AD 31/2 would be still in use well after Sejanus' downfall. There is no evidence that any of Pilate's coins were restruck with another design, and if they had been recalled then a need would have quickly arisen for a new coin before Agrippa's issue in 42/3. If there is any truth in Philo's statement that Tiberius issued instructions after Sejanus' death to all provincial governors ordering them, amongst other things, to respect the Jews and their laws (Leg 161), then the prolonged use of offensive coins in Judaea would be inexplicable.

From these arguments, therefore, a direct link between Pilate's coins and an anti-Semitic plot of Sejanus seems unlikely (if, in fact, such a 'plot' ever existed $^{1}$ ). But what is possible is that the coins more generally reflect a less compromising attitude felt within the empire towards the Jews. Pilate may have felt less inhibited by Jewish sensitivities than his predecessors, especially those under Augustus who seems to have particularly favoured the Jews ${ }^{2}$. His coins, therefore, show a freer blending of both Roman and Jewish designs.

More is known of the events of Pilate's governorship than any other prefect in the period AD 6-41. The following is a list of probable historical events:

Antiq 18.35 Pilate succeeded Gratus as procurator of Judaea.

c AD 26.

War 2.169-74

Pilate brought soldiers with imperial standards into

Antiq 18.55-59 Jerusalem. The people were upset and the standards eventually removed. This incident is often assumed to have taken place early in the governorship of Pilate; the

\footnotetext{
${ }^{1}$ As noted previously, Philo is our only source for this anti-Semitic attack. His writing in the Legatio is highly polemical and it is possible that he has deliberately portrayed Sejanus as anti-Semitic in order to highlight Tiberius' leniency towards the Jews; see Hennig, Seianus, pp 160-179 who doubts Sejanus' anti-Jewishness.

2 See Philo, Leg 157-159. Philo is, of course, going out of his way to show the favourable attitude shown towards the Jews by the emperors prior to Gaius, but some truth probably lies behind his description of Augustus' favour.
} 
evidence for this is that Josephus puts it first in both his accounts of Pilate's term of office ${ }^{1}$.

War 2.175-177 Pilate spent money from the Jerusalem temple to build an

Antiq 18.60-62 aqueduct. The Jewish people protested and many were executed.

Date unknown.

\section{Lk 13.1}

Pilate had some Galileans killed at passover

Date unknown.

Antiq 18.64

Pilate was responsible for the trial and condemnation to Tacitus Ann 15.44 crucifixion of Jesus of Nazareth. It was quite possible

Mk 15:44

Mt 27:11-26 that Pilate was acting on information brought to him by

Lk 23:1-25 the Jewish authorities as the gospels and Josephus imply.

Jn 18:28-19:16a Usually dated to AD 30 or 33 .

$\operatorname{Leg} 299-305$

Pilate erected aniconic shields in Jerusalem and, after complaints from the people and a letter from Tiberius, had them removed.

Shortly after AD 31.

Antiq 18.85-87 Pilate put down a Samaritan uprising; the leaders were put to death.

Winter AD 36/7.

Antiq 18.88-89 Pilate ordered to Rome by Vitellius.

Probably about Jan 37, Pilate reaches Rome after 16th March 37.

\section{Summary}

Pilate was appointed to the difficult task of governing the imperial province of Judaea; a small but potentially turbulent province encompassing

\footnotetext{
${ }^{1}$ For fuller accounts of each incident see the reler ant chapters.
} 
different types of people - Jews, Samaritans and pagans - each with their own cultural and religious sensibilities. The first six years of his rule were made more difficult by the absence of the Syrian legate, who could no longer be relied upon to intervene if difficulty arose, both on behalf of the people and the governor. Stable government in Judaea therefore depended to a greater degree than usual on interaction and negotiation between the prefect and the Jewish authorities. It would have been important not to allow uprisings to escalate, and this may have been the reason Pilate twice seems to have put down disturbances with more force than was necessary. The second of these uprisings, that concerning the Samaritans, led to his deposition. Pilate's coins, with their Jewish and Roman symbols, show that he, like the prefects before him, was willing to compromise to some extent; but the fact that he persistently employed Roman designs and his introduction of Roman standards into Jerusalem suggests that he wanted to bring the province into line with others in the empire. It may have been this emphasis on the Roman government of the province and his lack of compromise, coupled with an ill-considered attack on the Samaritans, which led to his dismissal. 


\section{CHAPTER 2 \\ Pilate in Philo}

Our earliest extant literary reference to Pontius Pilate is to be found within the writings of the diaspora Jew Philo of Alexandria. His Legatioad Gaium ( $\$ \$ 299-305$ ) contains a letter, supposedly from Agrippa I, recording an incident in which Pilate offended against the Jewish law by setting up aniconic shields in Jerusalem; the Jewish leaders appealed to Tiberius who ordered Pilate to remove them ${ }^{1}$. Philo's account is historically important in that, although belonging to Egypt, he was a contemporary of the events which he relates in Palestine $^{2}$. Furthermore, he would have had access to reasonably reliable information through his family connections with Agrippa $^{3}$. However, Philo's 'historical' writings, comprising of the Legatio ad Gaium (Embassy to Gaius) and the In Flaccum, are marked by a strong apologetic standpoint. This is particularly prominent in his assessment of the character and actions of Roman emperors and officials. Thus whilst Philo's account of Pilate doubtlessly contains a core of historical fact, his description of Pilate's character and intentions can only be assessed in the light of his general apologetic outlook. For this reason it is necessary first to analyse the apologetic motivation which has shaped Philo's 'historical' writings and then, subsequently, to reconstruct something of the historical Pilate behind the story.

\section{Legatio $\$ \$ 299-305$}

Pilate was an official who had been appointed procurator of Judaea. With the intention of annoying the Jews rather than of honouring

\footnotetext{
${ }^{1}$ On the basis of several references in Euscbius (particularly $H E$ 2.5.6ff) several scholars have assumed that much of Philo's 'historical' work has been lost, including a section on Pilate's anti-Jewish attitude (cg Masscbicau, 'Classement', pp 72-78; Cohn, 'Einleitung', p 421; Goodenough, Politics, p 9; Morris in Schürer, History, vol III.2 (rev), pp 359-366). More convincing, however, are the arguments of Colson (Embassy, pp xriv-rxv) and Smallwood (Iegatio, p 43) who maintain that apart from a lost ending (the 'palinode' referred to in $\$ 373$ ) our Legatio is virtually complete. Similarly, the In Flaccum may have contained an initial sectuon describing Sejanus' anti-Jewishness, but the remander of the work is intact (Colson, Flaccum, p 295, n. a). Philo's only reference to Pilate therefore seems to have been in Legatio 299-305.

${ }^{2}$ He lived from roughly $30 \mathrm{BC}$ to AD 45 (OCD 'Philon 4' $\mathrm{p} 684$ ).

${ }^{3}$ Philo's brother Alexander was the Alabarch of Alevandria (Antiq 18.259); Agrippa borrowed money from this man (Antiq 18.159-160). In AD 41 the same brother married Agrippa's daughter Berenice (Antiq 19.276). Although Agrippa himself was not directly involved in the event concerning Pilate which he relates, he would have lcarnt the details from his four relatives who were involved $($ Leg $\$ 300)$.
} 
Tiberius, he set up gilded shields in Herod's palace in the Holy City. They bore no figure and nothing else that was forbidden, but only the briefest possible inscription, which stated two things - the name of the dedicator and that of the person in whose honour the dedication was made. But when the Jews at large learnt of this action, which was indeed already widely known, they chose as their spokesmen the king's four sons, who enjoyed prestige and rank equal to that of kings, his other descendants, and their own officials, and besought Pilate to undo his innovation in the shape of the shields, and not to violate their native customs, which had hitherto been invariably preserved inviolate by kings and emperors alike. When Pilate, who was a man of inflexible, stubborn and cruel disposition, obstinately refused, they shouted, 'Do not cause a revolt! Do not cause a war! Do not break the peace! Disrespect done to our ancient laws brings no honour to the Emperor. Do not make Tiberius an excuse for insulting our nation. He does not want any of our traditions done away with. If you say that he does, show us some decree or letter or something of the sort, so that we may cease troubling you and appeal to our master by means of an embassy'. This last remark exasperated Pilate most of all, for he was afraid that if they really sent an embassy, they would bring accusations against the rest of his administration as well, specifying in detail his venality, his violence, his thefts, his assaults, his abusive behaviour, his frequent executions of untried prisoners, and his endless savage ferocity. So, as he was a spiteful and angry person, he was in a serious dilemma; for he had neither the courage to remove what he had once set up, nor the desire to do anything which would please his subjects, but at the same time he was well aware of Tiberius' firmness on these matters. When the Jewish officials saw this, and realized that Pilate was regretting what he had done, although he did not wish to show it, they wrote a letter to Tiberius, pleading their case as forcibly as they could. What words, what threats Tiberius uttered against Pilate when he read it! It would be superfluous to describe his anger, although he was not easily moved to anger, since his reaction speaks for itself. For immediately, without even waiting until the next day, he wrote to Pilate, reproaching and rebuking him a thousand times for his new-fangled audacity and telling him to remove the shields at once and have them taken from the capital to the coastal city of Caesarea (the city named Sebaste after your great-grandf ather), to be dedicated in the temple of Augustus. This was duly done. In this way both the honour of the emperor and the traditional policy regarding Jerusalem were alike preserved. ${ }^{1}$

The Context of Leg 299 - 305

Philo's reference to Pilate is found within a letter purporting to be from Agrippa I to Gaius Caligula, attempting to dissuade the emperor from setting up

\footnotetext{
${ }^{1}$ Smallwood's translation, Legatio, pp128-130.
} 
his statue in the Jerusalem temple (\$\$276-329). However, modern scholars are agreed that the letter as we now have it is clearly the work of Philo himself ${ }^{1}$. It is perfectly feasible that Agrippa wrote a letter to Gaius and also that Philo, who was in Rome at the time, knew something of its contents ${ }^{2}$. Yet, in accordance with historiography of his day, Philo has presented the letter in his own stylistic and theological terms. Thus the theology and apologetic of the letter are perfectly in keeping with that of the rest of the Legatio and In Flaccum.

\section{Theological and Political Apologetic in Philo's Historical Works}

Philo's Legatio and In Flaccum are a complex interweaving of theology and political apologetic. Philo uses theology to make political points and, at the same time, the political apologetic enhances his theology. Both have influenced the way in which Philo has portrayed Pilate. Although any rigid separation between the two is artificial to Philo's thought, for the sake of clarity it is easier to examine first Philo's theological outlook, one which he shares with other Jewish writers of his day, and how this has influenced even the words used to describe Pilate, and then to go on to consider the more concrete political situation behind the works and the way in which this too has shaped the characterization of Pilate.

\section{The Theology behind the Legatio and In Flaccum}

Throughout Philo's historical writings runs the common Jewish conviction that God is the divine protector of his people. The enemies of Israel are synonymously the enemies of God; he will not hesitate to intervene in history to vindicate his people and to judge their oppressors ${ }^{3}$. The measure by

\footnotetext{
${ }^{1}$ Lémonon, Pilate, p 208 notes the similar treatment of speeches by the author of Acts or Tacitus in Ann 11.24.

2 Josephus gives two different versions of events. In War 2.203 it was Gaius' death which prevents the erection of the statuc; but in Antiq 18.289-304 Agrippa prepared a magnificent banquet for Gaius and, being offered any favour he chose to name, asked for the plans regarding the statue to be abandoned. This account is suspect: the banquet has all the marks of Jewish lcgend such as Esther's banquet to save her people Est 5:1-8, or Salome's request for John the Baptist's head, Mk 6:21-29. Zeitlin argues that Philo's letter was composed in accordance with his theology, 'Did Agrippa?', pp 22-31.

${ }^{3}$ This idea can be found in other places throughout Philo's writings, eg Decal 47, Vit Cont 85-87, Praem Poen 169, 171, Cher 77. Sce Williamson, Philo, p 32. Borgen notes that Philo uses Pentateuchal principles as interpretative keys throughout the Legatio and In Flaccum; biblical passages are presupposed as background, Philo, p 48.
} 
which Roman emperors, officials and non-Jews generally are judged is by their attitude towards the Jewish nation and its law. In accordance with this overriding theological framework the characters within the story tend to become stereotyped; at one extreme are those who respect the Jewish nation and thus become paragons of every virtue; at the other are those who want to abolish the law and inflict sufferings on the Jewish people; often these characters end up suffering themselves.

Paramount amongst those who respected the Jewish law is the emperor Augustus. He approved of the Jews ( $(154)$, allowing those in Rome to meet on the Sabbath and to send their 'first fruits' to Jerusalem ( $\S 155-157)$. He showed such reverence for their traditions that he and his family gave dedications to the temple and ordered regular daily sacrifices to be made to the 'Most High God' at his own expense ( $\$ 157)$. He protected Jewish interests in the monthly distribution at Rome $(\S 158)^{1}$. Due to these benefactions Philo regards him as 'the emperor whose every virtue outshone human nature' (\$143). He goes so far as to claim that 'almost the whole human race would have been destroyed in internecine conflicts and disappeared completely, had it not been for one man, one princeps, Augustus, who deserves the title of 'Averter of Evil'. This is the Caesar who lulled the storms which were crashing everywhere, who healed the sicknesses common to Greeks and barbarians alike ... This is he who not merely loosened but broke the fetters which had confined and oppressed the world' ( $\S 144-146)$. In $\S 148$ he is a 'wonderful benefactor'.

A similar picture emerges of Tiberius. Philo mentions nothing of his alleged life of vice on Capri2; nor of his expulsion of Jews from Rome in AD 193. Instead, an 'upheaval in Italy' is briefly alluded to and associated with Sejanus who was 'contriving his attack' (\$159). Immediately after Sejanus' death Tiberius realized that 'the charges brought against the Jews living in Rome were unfounded slanders' $(\$ 160)$. He issued instructions to his

\footnotetext{
${ }^{1}$ See also within Agrippa's letter, $\$ \$ 309-318$.

${ }^{2}$ Recorded by Tacitus, Suctonius and Dio. Smallwood argues that Philo's description of Gaius' life with Tiberius on Capri as 'moderate' and 'healthy' (\$14) casts doubt on the reliability of 'Tacitus, Suctonius and Dio when they write of Tiberius' debauchery and Suctonıus' reference to Gaius' depravity there (Gaius 2): 'If Philo had been able to represent his enemy Gaius as leading a thoroughly disreputable life before as well as after his accession, he would hardly have failed to do so' (Legatio, p 164). Yet Philo's description at this point is conditioned by two motives. First, he is concerned to paint a favourable portrait of Tiberius from whom Gaius should have learnt to respect the Jewish law. Secondly, he goes on to show that Gaius' anti-Judaism and other crimes were a result of his illness; that is, that antiJudaism is 'unheal thy', or the result of madness.

3 If historical, this may have been because of excessive proselytism. See Josephus, Antiq 18.79-83; Suctonius, Tib 36; Dio 57.18.5a; and Tacitus, Ann 2.85.
} 
provincial governors 'to change nothing already sanctioned by custom, but to regard as a sacred trust both the Jews themselves, since they were of a peaceful disposition, and their laws, since they were conducive to public order' $(\$ 161)^{1}$. Tiberius is therefore credited with giving 'peace and the blessings of peace to the end of his life with ungrudging bounty of hand and heart' (\$141), and possessing a 'fine character' ( $\$ 142$ ). Augustus' wife Julia (Livia) donated costly items to the Jerusalem temple $(\$ 319)$ and receives praise for her natural ability, pure education and intellect $(\$ 320)$. Petronius too, because of his favourable disposition towards the Jews, has 'some glimmerings of Jewish philosophy and religion' either because of his interest in culture, a spontaneous inclination of his mind, or because 'God puts into good men's hearts good resolutions' ( $\$ \S 245-246)$.

Those characters within the story who do not respect the Jewish law, however, are characterized in an even more exaggerated manner. Central amongst these is the character of Gaius Caligula. Philo alleges that he 'felt an indescribable hatred for the Jews' ( Leg 133, 346), that he 'swelled with pride, not merely saying but actually thinking that he was a god' ( $\$ 162)$, that he was 'devoid of human feeling' ( $\$ 190)$, a megalomaniac $(\$ 194)$ and a fool $(\$ 77)$, an 'iron-hearted, pitiless creature' ( $\$ 87)$, a 'universal destroyer and murderer' (§89) and countless other such descriptions. Flaccus too attacked the Jews; his 'naturally tyrannical' nature achieved his designs through cunning $(F / 1)$. The final year of his prefecture of Egypt was characterized by the lack of fair and impartial hearings in disputes in which Jews were denied free speech ( $\$ 24)$. Publicly he acted as Agrippa's friend but 'in private he vented his jealousy and gave full utterance to his hatred by insulting him indirectly since he had not the courage to do so outright' ( $\$ 32$ ). The 'boundless excesses of his unjust and lawless actions' are described in detail $(F l 107,135)$.

Not only Gaius and the prefect of Egypt but also lesser Roman officials, the Alexandrian ringleaders and even the Alexandrian mob are described in similar language. Thus Capito, the collector of revenues in the imperial estate of Jamnia, held a grudge against the people of Jamnia and by 'robbery and embezzlement' amassed a large fortune, 'evading accusations by slandering those whom he had wronged' (Leg 199). Gaius' councillors Helicon and Apelles also receive brief but damning character sketches (Leg 203-204), both helped to poison Gaius' mind with their intense hatred for the Jews ( $\$ 205)$. Helicon is further described as 'a damnable and abominable slave' who had

\footnotetext{
${ }^{1}$ Again, a similar statement concerning Tiberius' respect for the Jewish law can be found within Agrippa's letter, $\$ 298$.
} 
wormed his way into the imperial household ( $\$ 166)$, accepting bribes from the Alexandrian envoys to continue with his anti-Jewish jibes ( $\$ 172)$. Philo's description of the Alexandrian mob is extremely vehement. In Leg 120 'the promiscuous and unruly Alexandrian mob ... unmasked the hatred which had long been smouldering and threw everything into chaos and confusion', attacking the Jews with 'insane and bestial fury' ( $\$ 121)$, 'madness and frenzied insanity' ( $\$ 132)$. These 'ruthless men' ( $F l 68$ ) subjected the Jews to all kinds of cruelty during the pogrom ( $F l 59$ ). In this they supposed they were pleasing Gaius (Leg 133, 201).

Of these aggressors, three are specifically said to have met with an unpleasant fate. The arrest, exile and murder of Flaccus is described in minute detail, taking up almost half of the treatise ( $F l$ 104191). Colson has highlighted the vindictive way in which Philo gloats over this' ${ }^{1}$. Gaius' advisers, Apelles and Helicon, 'received the wages of their sacrilege' later, and Philo describes their gruesome deaths ( $\$ 206)$. It is quite possible that the missing palinode to the Legatio, had it ever been written, described both a change in the fortunes of the Jews under Claudius and a graphic description of Gaius' assassination ${ }^{2}$. The underlying theme is that no-one can challenge God's people and their laws with impunity. In the case of Flaccus this is made explicit: his fate 'was caused, I am convinced, by his treatment of the Jews, whom in his craving for aggrandizement he had resolved to exterminate utterly' ( $F l 116)$, a fact which Flaccus himself is said to have realized before his death $(\S \S 170-175)$.

This interest in characterization and strongly emotional language marks Philo's writings as 'pathetic history'. A similar theologically inspired history and characterization is found throughout many Jewish works of the last two centuries $\mathrm{BC}^{3}$. One example is the book of Esther in which the King's official Haman, furious that Mordecai the Jew will not bow down and worship him, sets out to destroy the Jewish nation utterly $(3: 13,9: 24,25)$. The characterizations of the actors within the story are extremely sparse but, besides his hatred for the Jews, Haman is boastful (5:9-12) and conceited (6:6) ${ }^{4}$.

\footnotetext{
${ }^{1}$ Colson, Flaccum, p 301.

2 Williamson, Philo, p 32. The statement in Fl 191 that Flaccus 'also' suffered may imply that the fate of another, quite possibly Sejanus, $w$ as included in the first part of the work.

${ }^{3}$ The Legatio and In Flaccum also have similanties with the theologically based historywriting in the OT, though there is not so much stress on characters in the OT, and especially Greck historical cssay writing and moral talcs, though here, of course, there is not the same theological outlook; sce Borgen, Philo, p 50.

${ }^{4}$ Talmon argues that the boxh of Esther is an 'historicized wisdom tale', or an enactment of standard wisdom motifs, which explanns why the characters exhibit few 'real' qualities, 'Wisdom', pp 419-455. Philo nei cr directly cites Esther, possibly because its stark storyline
} 
Similarly, Nebuchadnezzar and Holophernes in the apocryphal book of Judith want to demolish all the sanctuaries in Judaea, so that Nebuchadnezzar alone would be worshipped by all peoples $(3: 8,6: 4)$. Holophernes is boastful and arrogant (6:18-9), trusting in the might of arms (9:7) and treating Israel with contempt (14:5). Both he and Haman pay for their attitudes towards the Jews with their lives (Est 7:10, Jud 13:8). Even closer are the parallels between the Legatio and In Flaccum and Maccabean literature; here there are even verbal similarities in the descriptions of the oppressors ${ }^{1}$. In particular, 2Macc, with its dramatic interest in the characters involved is especially close to Philo's historical works. Here again, characters are judged according to their attitude towards the Jewish law. Thus Onias, Judas, Eleazar and the seven brothers and their mother receive high commendation ${ }^{2}$ whilst Simon, the feuding High Priests Jason and Menelaus, Seleucid officials and Antiochus himself are described in terms reminiscent of Philo's vocabulary for impious men ${ }^{3}$. Antiochus has several parallels with Gaius: he wanted to dedicate the Jerusalem temple to Zeus (6:2), he is savage (5:11), merciless (5:12), audacious (5:15f), proud (5:17), a murderer and blasphemer (9:28), and has pretensions of being more than human $(5: 21,9: 8)$. Quite possibly the Seleucid king served as a model for Philo's description of Gaius. All those who oppose the Jewish nation receive their just retribution from God who protects his people. $3 \mathrm{Macc}$ exhibits a similar outlook. This book is particularly appropriate to Philo's position since it deals partly with events in Alexandria. Many Jews were abused and underwent a 'cruel and ignominious death' (3:25-6) at the hands of the proud and wicked king (2:2-3). However, God's providence again

and the absence of all the key religious concepts of Judaism did not lend themselves to his philosophical speculations.

'To take only the description of Pilate: the word $\dot{\alpha} \rho \alpha \gamma \eta$ is used of Try phon's spoiling the land (1Macc 13:34f) and Apollonius' attempt to seize the temple treasury (4 Macc 4:10);

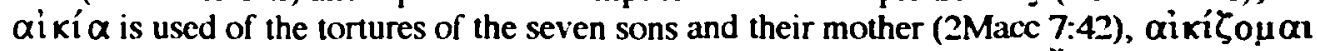
in 2Macc 7:1, 13, 15 and Philopater's torture of the Jew s (3Macc 4: 14); axxpITOS of the Hasidim who were wrongfully put to death rather than profane the Sabbath (IMacc 2:37);

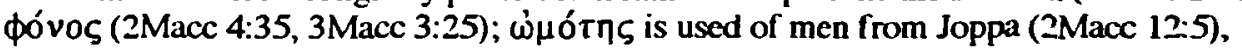
Philopater (3Macc 5:20, 7:5) and his friends (6:24).

The verbal similarities are not strong enough to suggest a literary dependence but both Philo's historical works and the Maccabean literature appear to have grou $n$ out of the same cultural and theological outlook in Alexandria. See IDB, 'Maccabees', pp 201-215. ${ }^{2}$ Onias 3:1, 4:2, 15:12; Judas 8:7, 12:38,42,45, 13:14, 15:7-17; Eleazar 6:18,23,31; sel en brothers $7: 1-41$.

${ }^{3}$ The author of $2 \mathrm{Macc}$ does not use the same vocabulary as Philo but the sense is extremely. similar. For Simon see 3:5,11, 4:1,4,6. Jason accepts bnbery (4:7) and shows boundless wickedness $(4: 8-10,13,19,5: 6,7,8)$. Menelaus has the 'temper of a cruel tyrant and the fury of a savage beast' $(4: 25,32,47,50,13: 4-8)$. Nicanor is sent to evterminate the entire Jewish race (8:9), is impious (8:14) and a villain (8:34, 15:3,5,6,32,35). On Lysimachus see 4:39,40,42. Antiochus Epiphanes is described in 1Mace 1:10,24,3:29,35, 6:11-13 and 4Macc 4:15, $5: 2,14,8: 1,9: 15,30$ (a description taken from 2Macc). 
intervened, thwarting the king's plans to level Judaea and destroy the Temple ${ }^{1}$. Josephus too employs a similar invective to Philo in his descriptions of the Jewish rebels ${ }^{2}$.

Turning back to the Legatio, Philo's description of Pilate perfectly conforms to this common picture of the Roman official bent on undermining the law of his Jewish subjects. He is described as wanting to annoy the Jews rather than honouring Caesar. His disposition is inflexible, stubborn and cruel, spiteful and angry, lacking in courage and unwilling to do anything to please his subjects. His administration showed his venality and violence and was a series of thefts, assaults, abusive behaviour, frequent executions of untried prisoners and endless savage ferocity.

An important point to be noted is that none of the adjectives used to describe Pilate, particularly those in $\S \S 301-302$, are used only of him throughout Philo's historical writings; every single one is also used to describe another character ${ }^{3}$. The charge of annoying the Jews rather than honouring Caesar was levelled against the Alexandrian mob in $F 7$ 51. In $\$ 301$ Pilate is

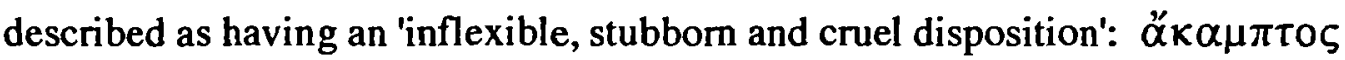
(inflexible) was used in $F \mathrm{l} 60$ of cruel captors who allow their captives to go for money, not mercy; $\alpha \dot{v} \theta \alpha ́ \delta n s$ (stubborn) occurs in $F l 35$ to refer to the evil

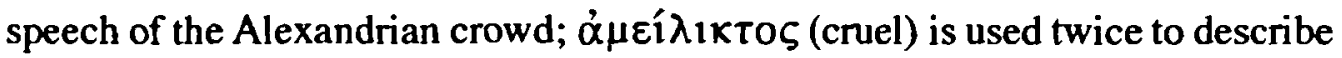
the character of Gaius ( $F l 182, \operatorname{Leg} 350$ ). The long list of Pilate's misdeeds in $\S \S 302-303$ finds similar parallels. $\Delta \omega \rho \circ \delta$ oxí $\alpha$ (taking of bribes) is used of the bribes given to Flaccus' accusers by Isodorus (Fl 140). Y $\beta \rho \mathrm{s} \varsigma$ (violence or pride) is often used, particularly of the Alexandrian mob $(F l 40,95,136)$ or of Flaccus' treatment of the Jews ( $F l 77$ ). A confiscation of large fortunes in $\mathrm{Leg} 105$ and often refers to the actions of the Alexandrian mob $(F l 56,57,62,69, \operatorname{Leg} 122,129)$. Ai kí $\alpha$ (insulting treatment, assaults) is again coupled with ü $\beta p r \varsigma$ in $F$ l 59 which states that $\dddot{v} \beta \rho ı \varsigma$ and $\alpha i$ ki $\alpha$ are not strong enough to describe the behaviour of the Alexandrian mob: $\alpha i$ kí $\alpha$ is further used of this group in Fl 71, 72, 96 and Leg 128. Ërípeı $\alpha$ (abusive behaviour) describes the conduct of Flaccus in $F 103$ and the Alexandrian mob in Leg 134. Ákpr tos (the condemnation of untried prisoners) is credited to both Flaccus ( $F l$ 54) and twice to Gaius (Leg 126, 241). Фóvos (murder, execution) is again ascribed to both Flaccus ( $F l 189$ )

\footnotetext{
${ }^{1}$ Philopator is not killed but instead has a miraculous conversion in the final chapter (7:9).

${ }^{2}$ Sce in particular War 7:259-274. War 4:162-192, 239-269 shows that by acting against God the rebels were bringing disaster on the nation. Herod too receives a poor press, Antiq 15:82, 209-212, 218, 16:150-159.

${ }^{3}$ This is also noticed by McGing, 'Pontius', pp 432-433.
} 
and Gaius (Leg 66). Precisely the same phrase which here refers to Pilate's

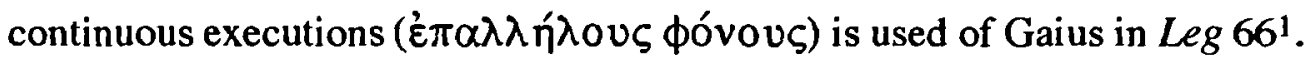
Similarly, Flaccus and the Alexandrian mob are responsible for 'unbroken and

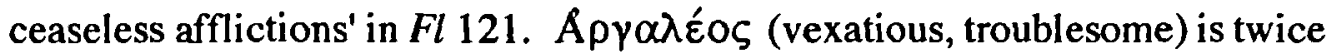
used of Gaius ( $F l$ 182, Leg 334), of the Alexandrian leaders ( $F l 21)$ and of the mob ( $F l 95)$. $\Omega \mu$ ótᄁৎ (savagery, cruelty) is used in Leg 341 to describe Gaius' excessive cruelty; in $\mathrm{Fl} \mathrm{59,66}$ to describe that of the Alexandrian mob. In Leg 199 Gaius' nature is described as है $\gamma \kappa o$ to (spiteful) and again in $\$ 260$, as are the Alexandrian leaders in $F l 19$. B $\alpha \rho v \mu \eta$ vios (heavy in wrath, angry) is used in Leg 260 of Gaius. Finally, in Leg 305 Tiberius describes

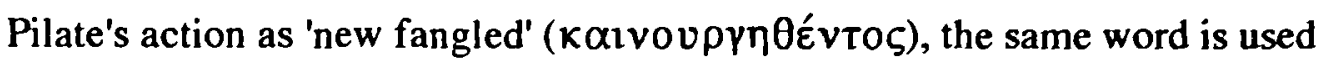
to describe the cruelty of the Alexandrian mob ( $F l$ 59), Gaius' statue ( $L e g$ 217) and Gaius' 'new fangled acts of megalomania' ( $\$ 348)$.

It is clear that Philo's description of Pilate is not a personalized attack but is a patchwork of set words and expressions regularly used by this writer for the enemies of the Jews, most notably Gaius and the Alexandrian mob. A further reference lends added support to this. In Fl 105 Philo gives a description of a corrupt governor:

'Some, indeed, of those who held governorships in the time of Tiberius and his father Caesar, had perverted their office of guardian and protector into domination and tyranny and had spread hopeless misery through their territories with their venality ( $\delta \omega \rho o \delta o k i \alpha)$, robbery ( $\dot{\alpha} \rho \pi \alpha \gamma \eta ́$ ), unjust sentences, expulsion and banishment of quite

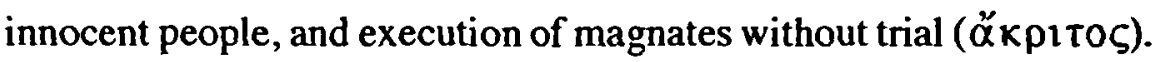
But these people on their return to Rome, after the termination of their time of office, had been required by the emperor to render an account and submit to scrutiny of their doings, particularly when the aggrieved cities sent ambassadors'.

There are clear parallels here with the description of Pilate in Leg 299-305. The sense of corrupt rule is the same, three words in the short description are identical; furthermore there is a reference to an embassy at which the misdeeds of the governor will come to light, a clear parallel to Pilate's fear in Leg 3022. In fact, the only concrete allegations made against Pilate in Leg $299 \mathrm{f}$ are precisely those also found in $F l 105$ - venality, robbery and executions of

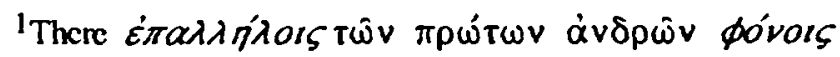

${ }^{2}$ It is unlikely that Philo was thinking specifically of Pilate's administration in his descrnpuon of $\mathrm{Fl} 105$; if this were the case, it would be strange to specifically refer to governors under Augustus. It is morc likcly that $F l 105$ gives, as it claims, an account of corrupt gor ernors in general. Philo would doubtlessly have had enough personal experience of governors of Egypt and other provinces without needing to think of Pilate at this point.
} 
prisoners without trial. When these are removed from the allegations against Pilate, little remains but character slurs - inflexible, stubborn, cruel, violent, insulting treatment, abuse, ferocity and anger - that is, nothing which could be positively verified or denied. Historically, Pilate may have been of a harsh disposition, at least he may have appeared so in Jewish eyes ${ }^{1}$, yet Philo's description of him is exaggerated in accordance with his own theological rhetoric. Pilate did not honour the Jewish law and so is described in precisely the same terms as other 'enemies' of the Jews: Gaius, Flaccus, Capito and the Alexandrians ${ }^{2}$.

\section{Political Apologetic in Philo's Historical Works}

The Legatio is not simply a timeless theological tract. It is related to a concrete historical and political situation which has also to some degree shaped the narrative involving Pilate.

Agrippa's letter, in which the reference to Pilate occurs, is a passionate appeal to the emperor Gaius not to desecrate the Jerusalem temple by the erection of his statue but to respect Jewish tradition like former emperors. On a larger scale the whole Legatio contains a similar plea. Goodenough suggested that the book was composed early in the reign of Claudius and that it is an attempt to persuade the new emperor not to follow the Jewish policies of Gaius but those of his predecessors, Augustus and Tiberius ${ }^{3}$. Philo achieves this apologetic aim in several ways, three of which are of importance for the passage involving Pilate:

1) A recurring theme of the Legatio (and the In Flaccum) is the assertion that the Jewish nation are loyal subjects of Rome. As long as their native customs are not interfered with, they want to be peaceful members of the empire. Philo asserts that Sejanus persecuted the Jewish race 'because he knew

\footnotetext{
1 The clashes later narrated by Josephus would have contributed to such a reputation, War 2.169-177; Antiq 18.55-62, 85-87.

${ }^{2}$ Unlike his description of Gaius' advisors and Flaccus, Philo narrates no miserable fate in the case of Pilate; he is only an incidental character in the story. There may however be a slight hint in Tiberius' angry rebuke and order that the shields be removed immediately ( $\$ 305)$ that the proud and crucl Pilate, like Flaccus $(F l 116)$, was humiliated before the people he was sent to govern.

${ }^{3}$ Leg 206 mentions events after Claudius' accession. See Goodenough, Politics, pp 19-20; Lémonon, Pilate, pp 207-208; this view is assumed by Schwartz, 'Josephus', p 32. Eusebius (HE 2.18.8) statcs that Philo read what he had written concerning Gaius' hatred of God before the Roman senate, possibly indicating an attempt to influence Claudius' policy.
} 
that, should the empire be in danger of being betrayed, it would offer in his defence the only, or the keenest, resistance to treacherous schemes and actions' (Leg 160). During the conflict over Gaius' statue, the Jewish leaders tell Petronius that they are striving for two ends: 'respect for the emperor and obedience to our hallowed laws' ( Leg 236) ${ }^{1}$. The exchange between Pilate and the Jews also centres upon this same theme: as loyal members of the Roman empire, the Jews do not want to be disrespectful towards their emperor (they refer to him as $\delta \varepsilon \sigma \pi o ́ \tau \eta \zeta$, master); yet as loyal Jews they cannot tolerate any dishonour shown to their God and his law. The story illustrates that there is no fundamental conflict between these two positions. By removing the shields 'both the honour of the emperor and the traditional policy regarding Jerusalem were alike preserved' (Leg 305). This accounts for Philo's slur upon Pilate's motivation: 'with the intention of annoying the Jews rather than of honouring Tiberius' (\$299). For Philo it is clear that 'disrespect done to our ancient laws brings no honour to the emperor' ( $\$ 301$ ); Pilate's action then can only have been with the intention of annoying the Jews. Exactly the same point was made with the Alexandrian mob which superficially appeared to be honouring Gaius by setting up images in the Alexandrian synagogues ( $F l 51, \operatorname{Leg} 133,201$ ). Respect for the Jewish law and for the emperor goes hand in hand: a model emperor like Tiberius recognized this immediately ( $\$ 304305)$.

2) Philo tries to persuade Claudius to adopt the policies of Augustus and Tiberius rather than those of Gaius by his use of characterization. As noted previously, this stems to a large extent from Philo's theological conviction that God protects Israel and that the enemies of the Jews are the enemies of God; but this theological conviction can be tumed to good political effect. Both Augustus and Tiberius are depicted as men of the highest moral standing, whose long reigns were peaceful and prosperous; their respect for the Jewish law and refusal to tamper with ancestral customs are repeatedly emphasized. Gaius, in contrast, set himself up as the enemy of the Jews, making an attempt on the temple and blatantly disregarding Jewish law in his absolute hatred for the people; he is described as a fool, a murderer and a madman. The Legatio and In Flaccum clearly show that anti-Judaism is a characteristic of the low-bom, base or disloyal. Sejanus' anti-Jewish policy was because he realized they were the most loyal subjects in the empire (Leg 160); Flaccus' actions were due to fear for his own position and because he had become 'utterly enfeebled' and 'incapable of solid judgement' ( $F l 16$, also 10); Capito's slanderous allegations

\footnotetext{
${ }^{1}$ See also Leg 230, 231-232 and $F / 48$.
} 
were prompted by fear of exposure ( $\$ 199)$; Gaius' own delusions and hatred for the Jews were the result of madness caused by illness. In contrast, Augustus' gifts to the temple were 'proof of his truly imperial character' (Leg 157). Clearly Claudius is to recognize not only that devotion to Judaism is perfectly in harmony with loyalty to the emperor, but also that respect for Judaism is the mark of a great man, in fact, an emperor of truly imperial character.

This apologetic concern leads to two tendencies within the scene with Pilate. First, Philo stresses Tiberius' concern in such a comparatively small issue, where no images were concerned and the offending shields were erected in the governor's private headquarters. To some extent the smallness of Pilate's offence is highlighted so that Tiberius' concern to rectify a small infringement of the Jewish law is in marked contrast to Gaius' planned desecration of the Jerusalem temple. Secondly, Philo emphasizes the baseness and depravity of Pilate's character in order to highlight Tiberius' virtuous imperial character.

3) A third way in which Philo tries to persuade Claudius not to adopt Gaius' policies is by means of a veiled threat. This has a double thrust: both the emperor himself and the peace of the empire are at risk if Claudius does not respect the Jewish law. The fates of Flaccus, Helicon, Apelles (and possibly Gaius in the lost ending of Legatio and Sejanus in the lost opening of the In Flaccum) show what happens to a ruler or official who sets himself against Judaism. Further, there are references to a great number of Jews all over the empire who would rise up to defend their religion should the need arise (Leg 216-217). The warnings of the Jewish spokesmen in $\S 301$, 'Do not cause a revolt! Do not cause a war! Do not break the peace!' are not empty threats. Philo warns that a deliberate attack on the Jewish law, such as Philo claims Pilate initiated, could indeed result in war and revolt throughout all the Jews resident in the empire. The rather exaggerated threats of $\$ 301$, therefore, may owe more to Philo's apologetic than to historical fact.

The Legatio may exhibit a subsidiary apologetic concern which also has relevance for the section on Pilate; this centres around Agrippa I and the Herodian dynasty.

Agrippa I played an important rôle in Claudius' succession ${ }^{1}$ and was rewarded with 'the whole of his grandfather's kingdom'2 which he ruled from

\footnotetext{
${ }^{1}$ Joscphus, War 2.206-217, Antiq 19.236-277.

2 War 2.215, including the districts of Trachonitis, Auranitis and Lysanias.
} 
AD 41-44. If, as seems likely, the Legatio was written shortly after Claudius' accession in 41, Agrippa was still on the Judaean throne. It is possible that a second apologetic concern of the Legatio was to persuade Claudius that Judaea should permanently be ruled by a Herodian. This would account for not only the glowing description of Agrippa himself ${ }^{1}$, but also that of the four Herodian princes in the conflict with Pilate who enjoy 'prestige and rank equal to that of Kings' and are the natural representatives of their people.

In the present text the conflict quickly centres around the Herodians with their entourage and Pilate. Tiberius, however, as arbitrator, upholds the Jewish position without a moment's hesitation ( $\$ \$ 304305)$. Philo thus shows that both the Herodians and Tiberius share the same basic view that loyalty to God is not incompatible with loyalty to the empire. The Herodians are therefore the natural leaders of Judaea both in their popular support and their sharing the same views as the emperor. In contrast, the Roman governor Pilate wants to please neither his people nor the emperor ( $\$ 303)$. The poor picture of Pilate, therefore, highlights not only Tiberius' good qualities but also those of the Herodians.

\section{Philo's Pilate}

In summary, Philo's characterization of Pilate has been shaped by his theological outlook, in which, in a similar way to other Jewish theologicalhistories of his period, he depicts the prefect in stereotyped language reserved for those who act against the Jewish law: he is inflexible, stubborn, spiteful and cowardly by disposition; his rule is characterized by corruption - bribery, violence, thefts, assaults, the condemnation of untried prisoners and continuous executions. Philo's political apologetic is also responsible for extra references in the narrative: the character of Pilate has to be blackened to contrast unfavourably with Tiberius and the Herodians. The description of Pilate's motivation in setting up the shields (ie to annoy the Jews, \$299) is also part of this apologetic, as is the suggestion that Pilate's actions were serious enough to provoke a war or revolt $(\$ 301)$.

\section{The Historical Event}

\footnotetext{
${ }^{1}$ See $\$ \$ 278,286$.
} 
When the nature of Philo's apologetic is recognized, it is possible to come to some plausible reconstruction of the historical event behind Leg 299305. Philo's own interpretation seems to be confined to his description of Pilate's character and motivation, not to the actual events. This is not surprising for two reasons. First, Philo was probably in possession of reasonably accurate facts through his friendship with Agrippa I; although this king was not directly involved, four of his close relatives were and very likely reported the incident to him. Secondly, Philo could not afford to blatantly misrepresent the facts. His argument at this point depends on showing Tiberius' respect for the law by his reaction to an incident caused by Pilate; if Philo's description of the event could easily be proved false, then his argument would lose all its force. Therefore it was possible to exaggerate, even to distort, Pilate's character but the facts of the incident had to be reasonably accurate.

\section{Pilate's Crime}

The most obvious first question is: in what way did Pilate's shields offend against the Jewish law? According to Leg 133 even synagogues in Alexandria contained 'gilded shields' (áorí $)$ set up in honour of the emperor and Josephus tells us that Solomon's temple also contained shields. What then was different about those set up by Pilate? Smallwood's translation of the relevant passage reads:

'He set up gilded shields in Herod's palace in the Holy City. They bore no figure and nothing else that was forbidden, but only the briefest possible inscription, which stated two things - the name of the dedicator and that of the person in whose honour the dedication was made' (Leg 299) 1 .

Several scholars have assumed either that the shields were inoffensive or that the offence was only slight, implying that Philo's narrative shows the hypersensitivities of the Jewish people regarding their law ${ }^{2}$. Certainly, in

\footnotetext{
${ }^{1}$ Smallwood, Legatio, p 128.

${ }^{2}$ The majonty of scholars assume that this incident took place after a similar incident recounted by Josephus in which Pilate introduced iconic standards into Jerusalem, War 2.169174, Antiq 18.55-59. Smallwood suggests that the incident with the standards aw akened the Jews to the fact that even aniconic objects could have (presumably religious) significance for the Romans and they were therefore anxious to keep these out of Jerusalem too. In short, al though the shields were themselves inoffensive, 'they feared that the introduction of aniconic shields was the thin end of the wedge' and could be the forerunner of a definite contrav ention of the law, Legatio, p 304. Maier asserts that there was 'no theological justification, per se, for the attitude of the Jerusalemites on this occasion' which may, he suggests, explain why Josephus makes no reference to it, 'Episode', p 118. Schürer, History, vol I (rev) p 386 and Schwartz, 'Josephus', pp 29-31 both assume the shields were inoffensive. In this respect, scholars have been too influenced by Philo's apologetic altempt to play dow n Pilate's crime, discussed above.
} 
accordance with his apologetic aims, Philo has played down the offensiveness of the shields; he stresses that they 'bore no figure', an obvious contrast to Gaius' statue. Yet the incident would lose all sense and parallelism if the shields were not offensive'. The basic aim is to show how a minor infringement of the law upset the Jews and how severely Tiberius remonstrated with the perpetrator. Some contravention of the law has to be present, otherwise Philo (in the guise of Agrippa) has at best only succeeded in highlighting the idiosyncrasies and hypersensitivities of his people; at worst he would have described a threatened revolt against a Roman prefect who had not transgressed the law. Neither would be likely to sway Gaius, within the context of the narrative, or Claudius, the probable recipient of the whole work ${ }^{2}$. In fact, Philo clearly states that there was something offensive about the shields. He writes: they bore no figure and nothing else that was forbidden, $\check{\varepsilon} \xi \omega$ nvò $\zeta$

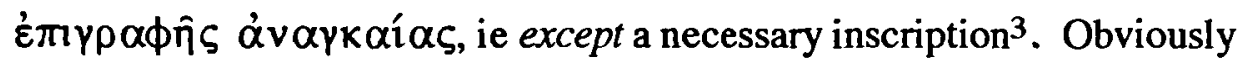
something about the inscription was forbidden. Philo elaborates on this: the

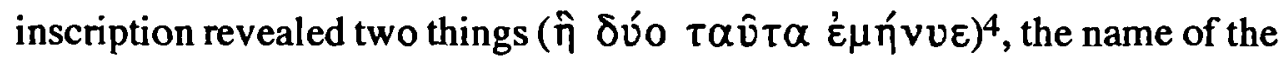
dedicator ( $\dot{\alpha} v \alpha \theta \varepsilon \dot{\varepsilon} v \alpha)$ and the one in whose honour the dedication was made

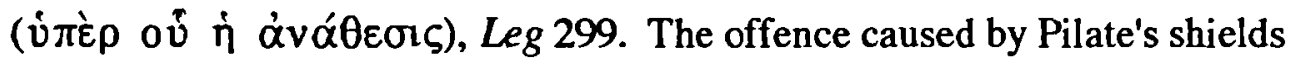
therefore lay in the wording of the inscription which contained the names of Pilate and Tiberius 5 .

In all probability Pilate referred to himself in a similar manner to the Caesarea inscription: (unknown first name) Pontius Pilatus; possibly adding his title: Praefectus Iudaeae. Since neither of these were offensive, the offence must be in the name of Tiberius. How did Pilate refer to him? The only other known inscriptions from Pilate referring to Tiberius are preserved on the prefect's coins. There Pilate followed the convention set by previous prefects who put only the emperor's name or its abbreviation on their coins, presumably not to cause offence by the use of the princep's official title. Pilate's coins read only TIB'. It is probable, however, that an honorific inscription destined for the governor's residence would refer to the emperor by his full title. Augustus'

\footnotetext{
${ }^{1}$ Lémonon, Pilate, also makes this point, p 217.

${ }^{2}$ Gaius already felt an indescribable hatred for the Jews ( $\operatorname{Leg} 133,346$ ) because they refused to accept his dıvinity $(\$ \S 353,357)$ and held their dietary sensibilities and monotheism in contempt $(\$ \S 361,367)$.

${ }^{3}$ Davies argues persuasively for the translation 'necessary inscription' rather than 'of a minimum size' suggested by Colson and Smallwood, 'Meaning', pp 109-110.

${ }^{4}$ A gain, Davies suggests the reading 'revealed' for $\dot{\mu} \mu$ rí $v v \varepsilon$, which is regularly used for the 'revelation of profoundly important facts', rather than simply 'to state', Meaning', pp 110-111. IIt scems reasonable to assume that Pilate was himself the dedicator, Smallwood, Legatio, $p$ 302. If another person had dedicated the shields it would be odd to find no reference to him or her.
} 
will imposed the title Augustus on Tiberius and a senatorial decree of 17 th September AD 14 made him divi filius. The title Pontifex Maximus was bestowed on him on the 10th March AD 15, a position to which he attached great importance ${ }^{1}$. The most common way to refer to Tiberius in short inscriptions was:

Ti. Caesari divi Augusti f. (divi Iuli nepoti) Augusto pontifici maximo ${ }^{2}$ Silver denarii issued by this emperor read TI(berius) CAESAR DIVI AVG(usti) F(ilius) AVGVSTVS on one side, PONTIF(ex) MAXIM(us) on the reverse ${ }^{3}$. It seems reasonable to suppose that Pilate's inscription followed official patterns and referred to Tiberius by his full title, including the phrase divi Augusti and quite possibly his position as pontifex maximus ${ }^{4}$. The reference to the divine Augustus would cause offense. As Fuks notes, the removal of the shields to the temple of Augustus in Caesarea ( $\$ 305)$ lends further support to the suggestion that it was the reference to the divinity of this emperor which was offensive. What offended the Jews therefore was the reference to a pagan deity - not Tiberius, as Brandon suggested 5 , but Augustus - and possibly too a reference to the supreme pontificate of the Imperial Cult situated, as Philo emphasizes, in the holy city of Jerusalem ${ }^{6}$.

So much we can infer from Philo's description; but is it possible to say anything further about Pilate's motivation in setting up the shields and whether he really wanted to cause offence? Here a fuller description of the uses of and designs upon honorific shields in the first century will be of some use.

It was an ancient custom to decorate shields used in warfare, often with the characteristics of the wearer, an abbreviation of his city or a picture 7 ; the shields themselves could also be used as decoration, set up in a public place in

'ILS 154; for Tiberius' attitude to the position of Pontifex Maximus see Grant, Aspects, $\mathrm{p}$ 45.

${ }^{2}$ See ILS $113,152,153,155,156,159,160,164,5818,5829,5829 a ; 114$ and 6080 omit 'pontificı maximo'.

${ }^{3}$ See for eg. Matthiac and Schönert-Geiß, Muenzen, p $98 f$.

4That is was the phrase divi Augusti which caused offence was pointed out by Fuks, 'Again', p 307.

5 Brandon, Jesus, p 74.

${ }^{6} \mathrm{~A}$ small number of scholars suggest that this incident is identical with Pilate's introduction of military standards recorded by Josephus, eg Colson, Embassy, pp xix-xx; Schwartz,

'Josephus', followed by McLaren, Power, pp 82f, n.l and Brown, Death, pp 702-703. This view depends to a large extent upon the prior assumption that the shields described by Philo were inoffensive. Since the Jewish reaction in Philo makes little sense, it is claimed, the writer must be simply presenting his own version of the military standards, greatly reducing Pilate's crime to contrast all the more with Gaius' planned desecration of the temple (see especially Schwartz, 'Josephus'). However, once it is recognized that the shields did contravene Jewish law, there is no need to resort to such harmonizations.

${ }^{7}$ See $P W$, 'Schild', cols 420-427, especially col 425; also 'Scutum', cols 914920. 
honour of a person or a god, or as a war trophy. The Greek $\alpha \sigma \pi i \zeta$, used here by Philo, corresponds to the Latin clipeus, a metal or marble disc bearing an image of a god, hero, or great man. Our fullest ancient description of such shields comes from Pliny in his Natural History $35^{1}$. In a passage relating to the painting of portraits, Pliny remarks: 'Bronze shields are now set up as monuments with a design in silver, with only a faint difference between the figures' (35:4); such objects, he comments, 'everybody views with pleasure and approval' (35:12). The first to start this custom, he claims, was Appius Claudius in $495 \mathrm{BC}$ who dedicated shields bearing portraits in the shrine of the goddess of war (35:12). Marcus Aemilius Lepidus set up similar shields in the Basilica Aemilia and his own home in $78 \mathrm{BC}(35: 13)^{2}$. A golden shield was set up in honour of Augustus in $27 \mathrm{BC}$ in recognition of his 'valour, clemency, justice and piety', the four cardinal virtues of the Stoics; a similar one was set up in AD 19 in honour of the oratory skills of Germanicus ${ }^{3}$. Coins of Tiberius, variously dated to AD 22-23 and 34-37, show shields containing a bust of the Princeps and the words 'Moderatio' and 'Clementia'4. Later, Caligula was awarded the honour of a gold shield which was to be carried to the capitol every year on a certain day by the Colleges of Priests ${ }^{5}$. Clearly the shields could be used either as religious dedications or as secular marks of honour ${ }^{6}$. The portrait shields also contained an honorific inscription, or elogium. This would include the name of the person honoured followed by his offices and triumphs 7 .

Pilate's shields belong to this type. They were not dedicatory, involving a pagan dedication ceremony, as some scholars suppose, but simply decorative shields set up in a secular place in honour of the emperor ${ }^{8}$. They differ in one

\footnotetext{
${ }^{1}$ Pliny lived c AD 23/4-79 and was therefore a contemporary of both Pilate and Philo.

2These are visible on coins struck in $61 \mathrm{BC}$ by his son of the same name; see Sandys, Latin, p 95.

${ }^{3}$ Res Gestae Divi Augusti 34; Tacitus, Ann 2.83. The last two examples are cited by Maier, 'Episode', pp 117-118; see also Levick, Tiberius, p 87.

${ }^{4}$ See Levick, Tiberius, p 87 who suggests that Tiberius was offered an honour similar to Augustus' shield.

${ }^{5}$ Suetonius, Gaius 16. A Carthaginian shield and golden statue was hung above the portals of the temple in the capitol until the fire of $83 \mathrm{BC}$, Pliny, NH 35.14. For two further portrait shields see Lémonon, Pilate, p 214. The Arcus Fabianus, restored by Q. Fabius Maximus in $56 \mathrm{BC}$, included statues, shields and emblems of victory, see Sandys, Latin, pp 95-97.

6Pliny speaks of Appius Claudius dedicating (dicare) shields in a goddess' shrine, but uses the secular word posuit (posse) when Marcus Aemilius set up shields in the Basilica Aemilia and in his own home.

${ }^{7}$ See Sandys, Latin, p 93f. These were generally affixed to statues (imagines maiorum) but were also attached to clipei to identify the portrait. Formulae giving the name of the person or body responsible for honorific statues were frequent (Sandys, p 108); it is less clear whether these were also generally found on clipei.

8 This was a suggestion of Pelletier, Legatio, p 375, taken up and developed by Lémonon, Pilate, p 213-217, and also favoured by Davies, 'Meaning', pp 112-114. The force of this
} 
important aspect, however, in that they did not contain a portrait of the emperor. This strongly suggests that Pilate deliberately used shields without portraits in an attempt to respect Jewish sensitivities ${ }^{1}$. If this occurred after the commotion caused by the images of Tiberius on the standards narrated by Josephus, then

Pilate's action was both understandable and prudent. He wanted to honour the emperor without antagonizing the Jewish people. Furthermore, the shields were set up inside ('́v) the governor's residence; they were not on an outer wall where they would be clearly visible to everyone in the city, but inside the Roman administrative headquarters where presumably other objects of a pagan

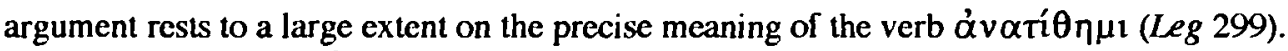
Of its various shades of meaning, the two which concern this inquiry are: a) to set up as a

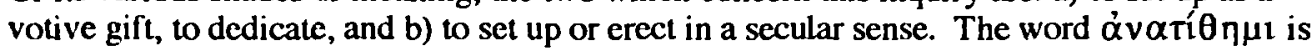
most often used in the Legatio to describe Gaius' proposed desecration of the Temple. Here again the verb could theoretically mean that the Jewish people were upset at Gaius' planned dedication of a statue of Zeus in the temple, but it more probably has the straight-forward secular sense of 'setting up'. It was the very thought that an image of any kind should be set up in the temple which gave offence, details over its dedication were secondary (Leg 188,260,265,335). The word is used again in Leg 135 and 136 in connection with a chariot dedicated to a woman named Cleopatra; it is however uncertain whether the chariot was dedicated with the aid of a pagan dedicatory service or simply set up in honour of the woman. $F / 41$ and Leg 346 mention images and statues of Gaius being installed ( $\left.\alpha v \alpha T^{\prime} \theta \eta \mu \mathrm{l}\right)$ in the Alexandrian synagogues; again the major cause of offence was that the images were there, that they had been set up in the synagogues, rather than dedicatory services associated with them. Finally, in Leg 365, Gaius orders pictures of himself to be set up around his house; clearly there is no pagan dedicatory ritual here. From this evidence, it seems a little unwise to assume that $\dot{\alpha} v \alpha \tau^{\prime} \theta \eta \mu \mathrm{l}$ means anything more than 'set up' here, or that it necessarily implıes a religious dedication involving a pagan ceremony. Furthermore, if this was the offence, to whom were the shields dedicated? Dedicatory inscriptions generally contained the name of the god or gods to whom they were dedicated and a dedicatory phrase or abbreviation, eg dedit (Sandys, pp 83ff); this Pilate's shields did not contain. Tiberius distiked divine honours and Pilate is unlikely to have deliberately provoked him on such an issue; besides,

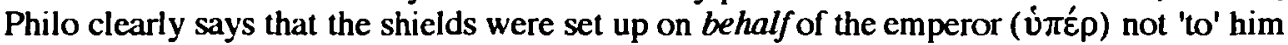
(Philo is well aware of this distinction, see Gaius' complaint in Leg 357). Lémonon thinks that the Jews thought that Pilate had dedicated the shields to the emperor ( $p 214$ ), though this is not supported by the text. Davies suggests that a religious ceremony dedicated the shields to the 'gods in heaven', 'Meaning', p 113. Yet the absence of any dedicatory formula suggests that the shields were honorific, nor dedicatory. Finally, this is further borne out by Philo/Agrippa's resume of the account. In Leg 306 he writes: 'Now on that occasion it was a question of shields. . . this time it is a colossal statue'. The offence concerned the shields themselves, not a dedicatory rite associated with them.

${ }^{1}$ Lémonon argues that because such shields generally contained images, Pilate's shields, even though aniconic themselves, offended in spirit against the law prohibiting images in that they suggested the presence of an image, Pilate, pp 215-216. Davies, 'Meaning', p 112 takes up this suggestion commenting 'the inscription was "necessary": if the portrait was missing, there had to be some way of identifying the person whose portrait Pilate hoped the Jews would imagine, and so the inscription was included in order to name Tiberius. The inscription was "forbidden": since the inscription was virtually playing the part of a portrait, acting as a substitute for the forbidden portrait which it was deliberately designed to evoke, the image could well be described as "forbidden"'. Neither scholar thinks that the offence lay in the reference to Augustus' divinity. Yet the solution they propose seems almost unbelievably subtle. We do not know how widespread such shields would have been in Judaea and whether the Jews would necessarily have associated them with portraits. More importantly, since such shelds contained tituli honorum to identify the person honoured by the shield (Sandys, Latin, p 93), the inscription was a nocessary but ordinary part of the clipeus and was not simply a substitute for a missing portrait. The presence of the inscription alone would emphasize that the portrait was missing, not deliberately evoke it. 
nature might be located. This was clearly the most appropriate place in Jerusalem for such honorific shields. Possibly Pilate realized that the reference to the divine Augustus was technically against the Jewish law (he did, after all, refrain from using it on his coins). He may have thought that, because of the location of the shields and the fact that the reference to Augustus was part of Tiberius' official imperial title, the Jewish people would not object or, out of reverence for their emperor, ought not to. If these were his thoughts, of course, he was wrong; the people did object.

But the Jewish reaction itself is interesting and may cast some light on Pilate's later actions. Philo's description is rather oddly constructed. Immediately after the reference to the 'forbidden inscription' he writes: 'But when the Jews at large learnt of his action, which was indeed already widely known, they chose as their spokesmen the king's four sons, ... and besought Pilate to undo his innovation in the shape of the shields' (Leg 300). This seems to imply a two-fold reaction: first of all Pilate's action was 'already widely

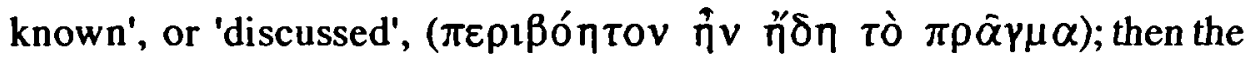

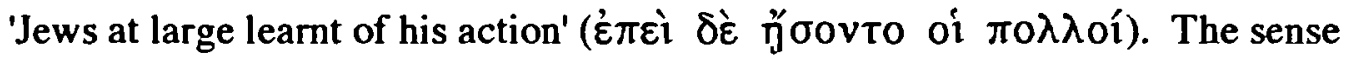
seems to be that the existence of the shields was generally known before the significance of the reference to Augustus was realized ${ }^{1}$. This would make good historical sense. First century Judaism, even in Jerusalem, was not monolithic as regards infringements of the law against images. Issues such as Gaius' statue and even Pilate's military standards with their images of Caesar were obvious affronts to the law and would rouse the Jews to immediate protest. Yet the silver denarii bearing the head of the emperor were in circulation in the holy city; the temple tax itself was paid in Tyrian shekels bearing the images of the gods Melkart and Tyche; both apparently were tolerated. Ironically Herod Antipas, who was probably one of the four Herodian spokesmen, had representations of animals in his palace in Tiberias ${ }^{2}$. It is quite possible that the consequences of Pilate's use of Tiberius' full title were not immediately obvious, or even important, to some Jews. Others, however, recognized that the reference to the divine Augustus meant that an allusion to a pagan deity was permanently situated in Yahweh's holy city. Those of a more anti-Roman persuasion may have welcomed a religious reason for ridding Jenusalem of shields honouring the emperor. Whatever the underlying motivations, the anti-

\footnotetext{
${ }^{1}$ Colson's translation similarly seems to imply that the Jewish outrage was not instantaneous: 'But when the multitude understood the matter which had now become a subject of common talk', Embassy, p 151.

2 Josephus, Life 65 . Josephus clcarly secs this as a breach of the law of Ex 20.4 prohibiting images.
} 
shields lobby became dominant and the four Herodian spokesmen were elected to put the Jewish grievances before Pilate.

The events of Leg 299-305 appear to have occurred at a feast: this is the likeliest explanation as to why four Herodian princes and Pilate should all be in Jerusalem at the same time. If the above reconstruction is correct, it may have taken some time for the Jerusalemites to be generally agreed that the shields were not to be tolerated. The Jewish leaders seem to have specifically waited until the feast to enlist the support of the Herodians whose known pro-Roman sympathies may have presumably carried more weight with the Roman prefect, especially in such a delicate issue. In this case, the shields may already have been in position for some weeks 1 .

The above considerations may help to clarify another puzzling aspect of the affair: Pilate's behaviour after the Herodian delegation. Philo asserts that the Jewish request to send an embassy to Tiberius worried Pilate because he was afraid that they would bring accusations against the rest of his administration ( $\operatorname{Leg} 302$ ); a fear which, if there were more than a grain of truth in the description of Pilate's atrocities, would be well-founded. The obvious line of action for such a merciless wretch as Pilate is presented as being would be to prevent the embassy at all costs and to remove the standards; it would presumably be better to lose face with his people than to lose his position, and possibly his life, at the hands of Tiberius. Philo attributes Pilate's failure to do this to cowardice and the lack of desire to do anything to please his subjects (§303). However, as we have seen, Philo's description of Pilate's character and motivation is highly suspect. Yet there is an explanation for Pilate's behaviour which is not entirely out of keeping with Philo's general claims and which fits into the historical situation.

From AD 23 onwards trials of maiestas, or treason, were an increasingly frequent feature of Tiberius' reign. From the fall of Sejanus in 31 until Tiberius' death in 37, Sejanus' enemies cast their nets further in an attempt to be avenged on his surviving friends ${ }^{2}$. Even if Pilate had no connection with Sejanus, it was not a time for a provincial governor to allow his loyalty to the emperor to be questioned. In fact, Pilate had set up the shields deliberately to honour the emperor. Philo is probably correct that the threat of an embassy to Tiberius put Pilate in a dilemma, but not because he was afraid of a poor report being given about his administration. If Pilate did what the people asked and

\footnotetext{
${ }^{1}$ Philo's account gives no indication as to how long the shields remained in Herod's palace.

2In the earlier period, AD 23-31, the trials centred around Agrippina, her sons and friends and were largely inspired by Sejanus. $O C D$, pp 640-641.
} 
removed the shields he would risk appearing to dishonour the emperor, especially if they had been up for some weeks without producing a spontaneous outcry and their offence against the Jewish law was not great; yet if he did not remove the shields the Herodians would appeal to Tiberius, doubtlessly giving their side of the affair and showing the insensitivities of the governor' ${ }^{1}$. Pilate obviously decided that the latter alternative was the safest; whatever the Herodian delegation claimed, Tiberius could not ignore the fact that the shields had been set up in his honour ${ }^{2}$. The fact that Pilate does not appear to have gone out of his way to stop the Herodians contacting Tiberius supports the view that his exaggerated characterization is largely due to the literary and theological art of Philo rather than real attributes of the historical man.

Philo's description of Tiberius' reaction is doubtlessly over-exaggerated in accordance with his apologetic aims, but the general sequence of events seems to support the above hypothesis. The emperor acknowledged the Jewish grounds for complaint, ordering Pilate to remove the shields from the holy city. Yet Pilate was not recalled, as he surely would have been if the Herodian letter made any serious allegations against his governorship. Nor is there the slightest hint that Pilate's loyalty to the emperor was ever in question ${ }^{3}$.

\section{The Date of the Incident}

One remaining question is: when did this incident occur? The majority of scholars assume that it took place in the latter part of Pilate's governorship for one (or all) of the three following reasons 4 :

1) If Pilate encountered opposition early on in his rule after his introduction of iconic military standards, then it is claimed that he would wait some time before bringing in aniconic shields 5 .

\footnotetext{
${ }^{1}$ Hoehner, Herod, $\mathrm{p} 183$ thinks that the enmity between Antipas and Pilate at the crucifixion of Jesus (for which he favours AD 33) was caused by the clash here between the Herodians and Pilate over the shields ( $L k$ 23:12). The execution of some Galileans (Lk 13:1), if it is historical and predates this event, may be another possible explanation for the enmity between the two men. See the chapter on 'Pilate in Luke-Acts'.

${ }^{2}$ It is not impossible that Pilate was in agreement with the Herodians over the writing of this letter. it was safer for him to wait for Tiberius' decision than to act on his own initiative and risk displeasing either the emperor or the people.

${ }^{3}$ Smallwood sees the inscription in Caesarea as a 'sequel to the episode of the shields', Jews, p 167. She believes that when Pilate's attempt to show his loyalty to the emperor failed, 'he conceived and carried out a much more ambitious project in Caesarea'. However, neither the construction of the Tiberiéum nor the incident concerning the shields can be dated exactly and a definite connection between the two cannot be substantiated. Pilate could have erected a secular building in honour of the emperor at any stage of his governorship.

${ }^{4}$ Often it is simply assumed, eg Brandon, Jesus, pp 71-75. The only exceptions to this scholarly consensus are those who think that the incident is identical with that recorded by Josephus concerning standards, see above $\mathrm{p} 60, \mathrm{n} 6$.

${ }^{5}$ Eg Schürer, History, vol I (rev), p 386.
} 
2) The list of Pilate's atrocities in $\$ 302$ would have taken some time to commit ${ }^{1}$.

3) It is claimed that Tiberius' anger at Pilate's high-handed attitude towards the Jewish law and Pilate's own indecision make best historical sense after Sejanus' assassination in $\mathrm{AD} 31^{2}$.

The first two arguments are far from conclusive. It is not necessary to assume that Pilate waited some years between bringing iconic standards into Jerusalem and the shields, especially since he took care that the shields contained no offensive portraits. His principal aim, as we have seen, was not to provoke the people but to honour the emperor. The list of Pilate's misdeeds in $\$ 302$ is part of Philo's stereotyped language applied to those who tampered with the Jewish law; it would certainly be difficult for Philo to give such a list if it were generally well known that this incident occurred in Pilate's first year, yet no certain time length can be established ${ }^{3}$. The strongest argument is that concerning the political situation after Sejanus' death when Pilate would not want to appear to be dishonouring the emperor by having the shields removed 4 .

Two further arguments can be made for a later date; nevertheless, although not particularly strong in themselves they add more probability to a later date. One is the fact that the inscription appears to have referred only to one person ( $\dot{u} \pi \grave{\rho} \rho$ ơ is singular). Pilate's coins struck before AD 29 refer to both Tiberius and his mother Julia, Augustus' wife. Many other communities similarly included Julia in inscriptions and dedications. After her death in AD 29 , the coins refer only to Tiberius. If Julia were still alive we might perhaps have expected her to have been also honoured by the shields. Secondly, the Jewish spokesmen appeal directly to Tiberius and not to the legate of Syria as was the standard procedure 5 . It may be that the Jewish leaders thought their best course of action was to appeal to the Herodians who, because of their position, could appeal directly to the emperor. Or, if the incident took place very soon after Sejanus' death there could be another explanation. Syria was without a legate 'in residence' until Flaccus' appointment some time in AD 32. Appeal to the legate would have been difficult before this date as the occupant of the post, L. Aelius Lamia, was in Rome. The Jewish leaders would therefore

\footnotetext{
${ }^{1}$ Eg Smallwood, Legatio, p 305.

${ }^{2}$ Eg Maier, 'Episode', pp 113-114; McGing 'Pontius', p 425; Fuks, 'Again', pp 501, 504505.

${ }^{3}$ Smallwood's attempt to match the 'crimes' with known or conjectured events in Pilate's governorship is not convincing, Legatio, p 305.

${ }^{4}$ This would be strengthened even more if Philo is correct in his assertion that Tiberius issued a reassurance to his Jewish subjects after Sejanus' death, Leg 161.

${ }^{5}$ See chapter 1 .
} 
have been forced to adopt a strategy such as we find in the shields incident in order to bring any pressure on Pilate ${ }^{1}$.

The incident of the shields therefore seems to have taken place at a feast shortly after Sejanus' death (17th October AD 31). This would also provide an historically significant motive for Pilate's erection of the shields: in the politically unstable conditions after Sejanus' fall Pilate wanted to demonstrate his loyalty to Caesar.

\section{Conclusion}

Philo presents us with a governor bent on annoying his subjects by the unprecedented erection of shields bearing forbidden inscriptions in Jerusalem. His character is described as spiteful, angry and lacking in courage, inflexible, stubborn and cruel; his government shows his venality, violence, thefts, assaults, abusive behaviour, frequent execution of untried prisoners, and endless savage ferocity. Yet Philo's description of Pilate conforms to those of other actors within the Legatio and In Flaccum who disrespect the Jewish nation and their law, in particular Gaius, the Alexandrian mob and the stereotyped 'corrupt governor' of $F l 105$. The description of Pilate's character and motivation stems from Philo's political apologetic, in which he tries to persuade Claudius not to adopt Gaius' attitude to the Jews, and his theology, in which the enemies of Judaism are the enemies of God and so are portrayed extremely negatively. This 'theologically interpreted history' 2 is found in other Jewish writings of the period, particularly 2 and 3 Maccabees, Josephus, Esther and Judith.

Behind the theological gloss, however, the historical Pilate is just visible; though Philo allowed his imagination to play a part in describing Pilate's character, his description of the facts seems trustworthy. Pilate appears as a governor intent on showing his loyalty to the emperor. This overriding concern and a fear that the removal of the shields would negate the whole project appear to have been his main priority rather than an attempt to respond to the wishes of his people. But Pilate's erection of the shields was not a

\footnotetext{
${ }^{1}$ For differing reasons Doyle, 'Pilate's', pp 191-193, suggests that this incident occurred at the passover of 32. Hochner, Herod, p 180f asserts: 'One objection to this is that it seems unlikely that Pilate would have tried to stir up trouble amongst the Jews so soon after hearing of Sejanus' death, especially since he may not have known about it until the winter of 31/2', he suggests the feast of Tabernacles instead. But by using aniconic shields Pilate seems to have deliberately tried not to 'stir up trouble'.

${ }^{2}$ Term used by Borgen, Philo, p 50.
} 
deliberate act of aggression as Philo maintains and several modern scholars have supposed. He seems to have gone out of his way to ensure that the shields did not contain portraits of the emperor and that they were set up inside the headquarters of the Roman administration, surely the most appropriate place for them in Jerusalem. Although he probably realized that Tiberius' full title could be offensive to some Jews, Pilate may have thought that the location of the shields inside the praetorium made them less offensive. Or, perhaps more likely, he thought that the Jews, like other peoples in the empire, should not object to honour being shown to their emperor. The intention behind Pilate's shields in Jerusalem was perhaps the same as that behind the his erection of a building known as the Tiberiéum in Caesarea: an attempt to honour Tiberius. The incident is probably to be located in the troubled times shortly after the death of Sejanus in AD 31. 


\section{CHAPTER 3}

\section{Pilate in Josephus}

The Jewish author Josephus refers to Pilate in his two major works: the Jewish War and the Antiquities of the Jews. The War, written c AD 75-79, contains two incidents concerning the prefect; the Antiquities, published about AD 93/4 adds two more and describes Pilate's return to Romel. Although both books were written in Rome under Flavian patronage and Josephus himself was born after Pilate's dismissal from Judaea, Josephus was a native of Jerusalem and his description of Pilate probably relies on information passed down to him by his parents and grandparents ${ }^{2}$. Yet, as was the case with Philo, Josephus' dramatic historical narrative has been shaped to some degree by his particular theological and apologetic aims.

The following discussion will analyse Josephus' works separately, taking into consideration their particular theological and apologetic aims and the role Pilate plays in each one. This will be followed by a consideration of the historical background behind each incident.

\section{The Jewish War}

\section{a) Purposes}

In his first literary work Josephus has three important aims: to explain the tragedy which befell the Jewish people, in particular the destruction of the temple; to attempt to improve the strained relations between Jews and Romans after the war; and, most importantly, to impress on other nations the futility of revolt against Rome $^{3}$.

\footnotetext{
${ }^{1}$ For detailed discussions of the life and works of Josephus see especially Bilde, Flavius ; Rajak, Josephus; Cohen, Josephus; A ttridge 'Josephus', in CRINT, pp 185-232; Feldman, Josephus', $A B D$, Vol III, pp 981-998.

2 In Life 5 Joscphus states that he $u$ as born in the first year of Gaius' reign, AD 37/8, ie a year or two after Pilate's departure. He probably dicd around AD 100 (Attridge, 'Josephus', p 195). In War 1.3 he claims to be a native of Jcrusalem and of priestly descent.

${ }^{3}$ Other aims which are less relevant to this study include praising his Flavian benefactors, especially Titus, and to portray himself in a more favourable light. Sce Bilde, Flavius, p 7578.
} 
Josephus understands and interprets the catastrophic political events leading to the war in theological terms ${ }^{1}$. The blame, he maintains, lay with no foreign nation but the Jews themselves ${ }^{2}$. Internal strife between Jewish factions led to disunity amongst God's people and the transgression of the law by those in favour of revolt ${ }^{3}$. Throughout the narrative is the conviction that God has abandoned his people to their sin and now favours the Roman side 4 . God used the Romans to chastise his people: the fall of Jerusalem and the destruction of the temple were therefore the just punishment for the sins of the nation $(2.455,4.323,5.19)$. This theological interpretation of events has close parallels with the OT, particularly prophetic, understanding of God using foreign nations to chastise his people 5 .

However Josephus clearly points out that it was not the whole Jewish nation which was guilty of transgressing God's law and so arousing his anger but only certain groups, in particular those who supported the revolt against Rome and their corrupt leaders. This ties in with his second apologetic aim, that of attempting to restore the friendlier, pre-war relations between Jews and Romans. He does this primarily by analysing the causes of the war. He repeatedly stresses that the Jewish people as a whole were not responsible for the revolt; the blame should rather be placed on a small group of rebels who stirred up the nation with their militant aims. These fanatics are variously described as 'tyrants' and 'bandits'6. Although admitting their Jewish origin, Josephus wants to show that these men generally did not represent the feelings of the Jewish populace, the majority of whom remained pro-Roman as too did the Jewish authorities, Agrippa and the chief priests, and the major Jewish philosophies ${ }^{7}$. By this device, Josephus hoped to exonerate the Jewish people

\footnotetext{
${ }^{1}$ Although by now the beneficiary of the Flavian emperors, Josephus retained his Judaism. His keen sense of the tragedy which befell his people lends a touch of personal anguish to his
} narrative, eg 1.9-12, 5.20.

$21.12,5.257,6.251$.

32.454-456, 4.314-318,383-388 (esp \$385), 6.99-102,108, 7.260.

${ }^{4}$ For example, God is behind Roman success in Palestine: $3.293,404,494,4.297,323,370$, $5.2,39,343,6.39 f f, 110,250,399,401,7.32,319$.

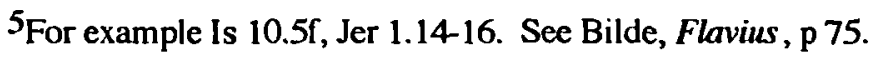

${ }^{6}$ Túpavvor $\lambda$ ṇotót. See for example 1.4,10,24,27 etc. The disturbances after Herod's death are similarly ascribed to an extreme nationalistic element, $2.53,56,65$. The atrocities of their deeds are described in $4.382 \mathrm{f}$.

${ }^{7}$ War 1.10-11,27, 2.264-265,271 etc. Agrippa makes a speech against the war in 2.345ff; the chief priests, notable citizens and temple ministers similarly try to prevent it $(2.320,417)$; the people of Tiberias and Tarichaeae wanted peace $(3.448,492)$; the people in besieged Jerusalem anxiously awaited the arrival of the Romans $(5.28,53,335)$; many of the upper classes want to desert (6.113). Josephus claims that the nationalistic Fourth Philosophy founded by Judas the Galilean which advocated the non-payment of tribute and refusal to tolerate mortal masters had nothing in common with the other philosophies (2.118). By this exaggeration he implies that the other philosophies were content to accept the Romans, stating 
generally and to show that contemporary Roman ill-treatment was out of place as the people had suffered enough at the hands of their compatriots.

Along with the Jewish nationalists Josephus also puts blame for the revolt upon the last two Roman procurators of Judaea: Albinus and Florus. Under the governorship of Albinus were sown in the city the seeds of its impending fall (2.276) and his successor Florus is charged with deliberately wanting war to hide his own excesses ${ }^{1}$. The revolt therefore, according to the War, was caused by the agitation of nationalist brigands and the ill-treatment of the nation by its last two governors rather than any innate tendency of the people to rebel. Instead, they generally tended to be peaceably inclined and should not be held responsible for the atrocities which occurred.

That the resistance of the nationalistic brigands was misguided and futile is stressed throughout the work. The might of Rome and the futility of revolt amongst subject peoples is one of the most dominant themes of the War and, at least as far as Josephus' Flavian patrons would have been concerned, was the most important motive for the work's composition. Josephus had already written an account of the war in Aramaic which was distributed to the Parthians, Babylonians, remote tribes of Arabia, those living beyond the Euphrates and the inhabitants of Adiabene $(1.3,6)$ outlining the origins of the war, its various phases and conclusion $(1.6)^{2}$. It is easy to see the value of such an account as a 'manifesto intended as a warning to the east of the futility of further opposition and to allay the after-war thirst for revenge, which ultimately led to the fierce outbreaks under Trajan and Hadrian'3. The present Greek edition has the same objectives in mind but is addressed to all the 'subjects of the Roman Empire' (1.3). Josephus uses the Jewish revolt as an example to deter others, especially by his gruesome description of conditions in Jerusalem during the Roman siege ${ }^{4}$. Although he acknowledges Jewish

this explicitly in the case of the Essenes who obeyed mortal rulers 'since no ruler attains his office save by the will of God' (2.140). Rajak however warns against an over-simplified view of Josephus' description, noting that in the earlier stages of the revolt he does admit that there was a middle element who were sometimes behind the war party, Joseplus, p 83.

$12.293,299,318,333$ etc. A fuller discussion of Josephus' appraisal of Roman governors will be given in the next section.

${ }^{2}$ Both the original Aramaic version and the Greek seem to have been officially inspired; in Life 363 and Apion 1.50ff Josephus asserts that Titus gave his signature to the War. On Rome's attitude towards Parthia and other lands to the east of the empire see B. Isaac, Limits, who argues that the Roman troops deployed at the frontiers of the empire were'geared for aggressive diplomacy or even offensive warfare rather than defence, at least until the Byzantine period', p 33.

${ }^{3}$ Thackeray, Jewish, vol ii, p x; see also Stern 'Josephus', pp 71-80.

${ }^{4}$ See for example 5.429ff,511ff,567ff, 6.1ff,193ff (the mother who ate her own baby), 6.201 213 , and 7.112 . 
successes against the Romans ${ }^{1}$, the superior might of the Roman army is repeatedly emphasized: its missiles (3.244), artillery (5.269), and its victorious siege engine (5.269) ${ }^{2}$. 3.70-109 contains a long digression on the Roman army - its composition, weaponry, tactics etc - explicitly to 'deter others who may be tempted to revolt' $(\$ 108)$.

But what seals the invincibility of Rome for Josephus is not only the prowess of its armies but the fact that the empire has God as an ally. God was behind Augustus' success at Actium (1.390), he is behind the empire (2.390), shaping its destiny (3.6), directing Vespasian to the Principate (3.404) and committing the empire to him and his son Titus (5.2). Revolt against Rome is therefore revolt against God. This is made particularly clear in Josephus' speech to his besieged countrymen in 5.362-419. God now rests over Italy bringing power to Rome ( $\$ 367)$, war with Rome is war with God (\$378), the only way to salvation for the Israelites is to put down their weapons and accept Roman sovereignty ( $\$ \$ 415 f$ ). A similar sentiment is put into the mouth of Agrippa in his speech shortly before the outbreak of the revolt (2.345-404). All other nations submit to Rome ( $\$ 358-361)$, Judaea could not possibly withstand the might of the Roman empire ( $\$ 357$ ) especially since God is behind it ( $\$ 390,394)$. Agrippa's advice (which was not heeded for long) is also Josephus' advice to the subjects of the Roman empire: pay tribute and accept Roman control. At the end of the revolt, Eleazar's speech to his fellow Zealots on Masada forms a counter-part to that of Agrippa's ${ }^{3}$ (7.323336). Ironically the rebel leader realized too late that God had doomed the Jewish race to perdition ( $\$ \S 327 \mathrm{ff}$ ), that their defeat was the penalty for their crimes (7.331), and that God's intervention resulted in victory for the Romans ( $\$ 358 f f$ ). The message of the War is clear: the Jews should quietly put their trust in God rather than attempt to alter his guidance of history by taking up arms; the passive protest against Gaius' statue illustrates the effectiveness of such non-violence and trust in God (2.184-203). The story of the Jewish revolt, however, is a graphic illustration of what happens when a subject nation rises up and takes on the power of Rome and is a dire warning to others of the tragic consequences to which such action leads.

\footnotetext{
${ }^{1}$ This is part of his historical concern not to underestimate the Jewish achievements, 1.7-8. In fact it enhances the prestige of the victorious Roman armies if their opponents put up a strong fight.

${ }^{2}$ See also 1.21-22,142, 2.72,199,354,357,362,373, 5.348ff, 6.22; the Gauls were overawed by the strength of Rome 2.362-379, as were other great nations, 2.365-379,577 3.31. Titus' speech in 3.472-484 makes the same point. The pictures in the triumphal procession in Rome show the might of the Roman troops taking Jerusalem, 7.139.

${ }^{3}$ This observation was made by Thackeray, Jewish, vol iii, p 600 , n. a.
} 


\section{b) Pilate in the Jewish War}

In this work Josephus relates two incidents involving Pilate - one centring on his introduction of iconic standards into Jerusalem, the other on his appropriation of Temple funds to build an aqueduct in Jerusalem. Pilate is introduced abruptly in 2.169 and there is no reference to his departure. The texts are as follows ${ }^{1}$ :

War 2.169-174

Pilate, being sent by Tiberius as procurator to Judaea, introduced into Jerusalem by night and under cover the effigies of Caesar which are called standards. This proceeding, when day broke, aroused immense excitement among the Jews; those on the spot were in consternation, considering their laws to have been trampled under foot, as those laws permit no image to be erected in the city; while the indignation of the townspeople stirred the countryfolk, who flocked together in crowds. Hastening after Pilate to Caesarea, the Jews implored him to remove the standards from Jerusalem and to uphold the laws of their ancestors. When Pilate refused, they fell prostrate around his house and for five whole days and nights remained motionless in that position.

On the ensuing day Pilate took his seat on his tribunal in the great stadium and summoning the multitude, with the apparent intention of answering them, gave the arranged signal to his armed soldiers to surround the Jews. Finding themselves in a ring of troops, three deep, the Jews were struck dumb at this unexpected sight. Pilate, after threatening to cut them down, if they refused to admit Caesar's images, signalled to the soldiers to draw their swords. Thereupon the Jews, as by concerted action, flung themselves in a body on the ground, extended their necks, and exclaimed that they were ready rather to die than to transgress the law. Overcome with astonishment at such intense religious zeal, Pilate gave orders for the immediate removal of the standards from Jerusalem.

\section{War 2.175-177}

On a later occasion he provoked a fresh uproar by expending upon the construction of an aqueduct the sacred treasure known as Corbonas; the water was brought from a distance of 400 furlongs. Indignant at this proceeding, the populace formed a ring round the tribunal of Pilate, then on a visit to Jerusalem, and besieged him with angry clamour. He, foreseeing the tumult, had interspersed among the crowd a troop of his soldiers, armed but disguised in civilian dress, with orders not to use their swords, but to beat any rioters with cudgels. He now from his tribunal gave the agreed signal. Large numbers of the Jews perished, some from the blows which they received, others trodden to death by their companions in the ensuing flight. Cowed by the fate of the victims, the multitude was reduced to silence.

\footnotetext{
${ }^{1}$ Taken from Thackeray, Jewish, vol ii, pp 389-393.
} 


\section{Context}

Before analysing each text in detail, Pilate's governorship needs to be set in its general context. Book 1 and the first part of Book 2 of the War provide an extended introduction to the Jewish revolt. They describe the rise and fall of the Hasmonaean dynasty, leading to Roman involvement in Judaea, indirect Roman rule through the reign of Herod I and his three sons, and subsequent direct Roman rule by prefects and later procurators. Josephus describes the reigns of the later Hasmonaean kings as a period of turbulence and instability, gradually giving rise to a period of repressive peace from 32 BC onwards under Herod I ${ }^{1}$. With the king's death and Archelaus' journey to Rome fresh disturbances arose and the country was plunged into virtual anarchy (2.1ff), eventually being forcibly put down by Varus (2.66-79). It is at this point in the War that the first Jewish embassy appears in Rome to ask that their country be united to Syria (2.80-92). This time Augustus refuses the request and chooses to abide by the terms of Herod's will, appointing Archelaus as ethnarch of Judaea (2.93ff). Later on, however, after receiving complaints from both Samaritans and Judaeans (2.111), Augustus deposes Archelaus and grants the Jews their request, formally uniting them to the empire (2.117). According to the Jewish War therefore the annexation of Judaea was at the request of the people themselves and is portrayed as a concession to them from the emperor. Of the next thirty-one years, until Agrippa I's reign (AD 41-44), Josephus reports very little. Of the seven prefects governing Judaea during this time Josephus refers to only two: Coponius, the first governor (2.117f) and Pilate (2.169-177). Although he relates the rise of Judas the Galilean under Coponius and two incidents involving Pilate, the general impression is that these were relatively stable years when the majority of the population were content with Roman rule. It is only much later in the more detailed description of Felix's governorship that we hear of the rise of brigands ( $\lambda$ notóa, 2.253), and the emergence of sicarii

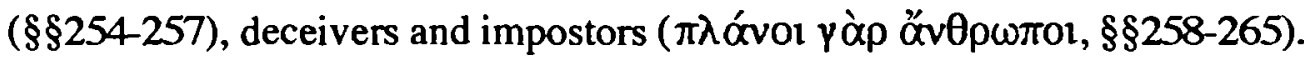
The relative tranquillity of the first phase of direct Roman rule is reinforced by the fact that the largest part of Josephus' narrative at this point is dedicated to a description of 'Jewish philosophies' ( $\phi 1 \lambda$ oooфeit $\alpha$ ): the Pharisees, Sadducees and Essenes (2.119-166). The context for Josephus' narratives concerning Pilate therefore belong to the Jewish War's relatively harmonious picture of

${ }^{1} 1.364$ credits Herod with ridding Judaea of disturbances from this date. 
Judaea between Archelaus' deposition and the accession of Gaius Caligula and Agrippa I $^{1}$.

\section{Apologetic Themes within the Two Stories}

The two incidents concerning Pilate both show the same characteristics which are firmly linked with Josephus' overall apologetic aims in the War. First, they have the same structure built around cause and effect ${ }^{2}$ : an action of Pilate provokes the people, this causes a Jewish reaction which in turn necessitates a counter-reaction from Pilate. This scheme is developed furthest in the episode of the standards. Throughout the narrative we are continually presented with a series of actions and reactions between the two actors in the drama, Pilate and the people, each dependent on the previous response.

Secondly, in both narratives the emphasis is not so much on Pilate's initial action as the Jewish reaction and what effect this produces on the Roman prefect. In both, Pilate's initial offence is described briefly and serves primarily as a catalyst which sparks off the Jewish reaction. In the first we are told only that Pilate brought in the standards by night. Josephus is not interested in telling us why Pilate brought new standards into Jerusalem or upon whose authority he was acting, he is introduced abruptly with no biographical detail except that he was 'governor of Judaea' (even the title غ̇лí caused offence by using temple money to build an aqueduct; but many important details such as why Pilate used this money and how he acquired it are absent. These details, especially those to do with the Corbonas, would presumably have been equally mystifying to Josephus' contemporary nonJewish readers as they are to a modern reader. At other points in his narrative Josephus explains Jewish customs and religious sensitivities to his audience ${ }^{4}$; that he does not do so here again emphasizes that the details of Pilate's 'crimes' are not of paramount importance to him. What is important is the way in which the Jewish people react to Pilate's deeds. This is made even clearer by the opening sentence of the aqueduct narrative: 'On a later occasion he

\footnotetext{
${ }^{1}$ For an historical evaluation of Josephus' account at this point see chapter 1.

${ }^{2}$ This is also noticed by Lémonon, Pilate, p 146.

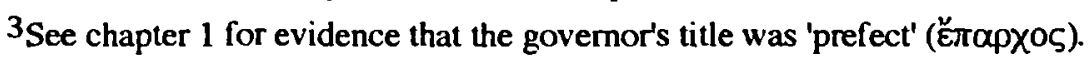

4For example in 1.270 he explains why Antigonus lacerated Hyrcanus' ears; at 1.477 he explains that polygamy is permitted by Jewish custom; at 1.650 that it is unlawful to put images or busts in the temple; see also 2.42,456, and 6.425.
} 


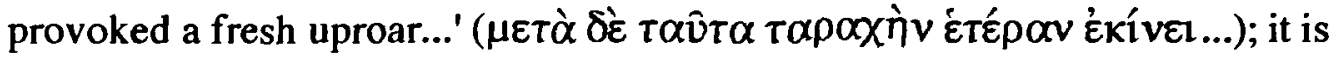
clearly the Jewish response, in this case an uproar, which is the focus of attention.

Josephus relates two actions of Pilate which led to two different Jewish reactions. In the first, the Jews are entirely peaceful and passive; they go to Caesarea and without aggression implore Pilate to remove the standards; even after five days and nights they refrain from violence, accepting death rather than the violation of their laws. Pilate, astonished by their religious devotion accepted their arguments and removed the standards. By his narrative of this incident therefore Josephus showed that a passive demonstration showing respect for and submission to the governor could achieve its aim. The reaction occasioned by the aqueduct, however, was of a completely different order. The people showed aggression towards Pilate, they surrounded his tribunal and 'besieged him with angry clamour'

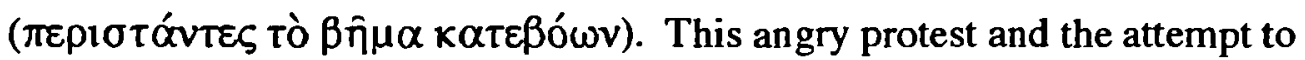
intimidate the governor produced a massacre, a blatant display of the might of Rome. The final line is heavily dramatic: the severity of the Roman troops and the large number of victims reduced the multitude to silence. This narrative therefore shows that an angry protest will not succeed and can only end in bloodshed and disaster for the people.

It is no coincidence that these two incidents together illustrate the most important apologetic purpose of the War: opposition in the form of riots or angry tumults is useless, Rome is far too strong. Only a passive respectful protest can hope to succeed. Josephus uses a similar technique when he juxtaposes two incidents from the governorship of Cumanus; one involving a violent protest (2.223-227), the other non-militant (2.228-232) ${ }^{1}$. Later the moral of these pairs of stories under Pilate and Cumanus is given verbal expression by Agrippa in his speech attempting to stall the outbreak of the revolt (2.345-404): even if a governor rules badly 'the powers that be should be conciliated by flattery, not irritated', 'there is nothing to check blows like submission and the resignation of the wronged victim puts the wrongdoer to confusion' ( $\$ \S 350 f)$.

The two incidents in Pilate's governorship, coming at a time of relative peace, seem therefore to highlight the two options open not only to Jews but to all subjects of the Roman empire: accept Roman rule peacefully and its

\footnotetext{
IIn all, Josephus describes three incidents which occurred under Cumanus' governorship. The third describes a conflict between Galileans and Samaritans which, due to his tardiness in dealing with the problem, led to Cumanus' banishment (2.232-245).
} 
governors will show consideration, or resort to violence and risk certain annihilation at the hands of Roman troops. The next clash between Jews and Rome narrated in the War concerns Gaius' statue (2.184-203). Here the Jewish protest has close parallels with that occasioned by the standards. The people peacefully appeal en masse to the legate, Petronius, offering to die rather than transgress their laws. This behaviour favourably impressed Petronius, as it had Pilate earlier, who resolved to delay the statue. The demonstration finally succeeded with God's help (2.186). In this incident the people seem to have heeded the lesson of the episodes in Pilate's administration. The affair of the aqueduct, however, remains as a warning against more aggressive action and it is this policy, rather than the successful peaceful protests of the standards and Gaius' statue, which is eventually employed by members of the war party with disastrous results for the nation.

\section{The Characterization of Pilate in the War}

In view of the apologetic effect to which Josephus puts his two incidents involving Pilate, it is no surprise that the prefect is briefly described with only the barest biographical details and no general word on his administration as a whole. Josephus is not so much interested in describing the person and governorship of Pilate as the effects which two of his actions provoked. Nor does Josephus give us any portrayal of Pilate's character ${ }^{1}$. This clearly shows both that the governor is very much an incidental character within the story and also that Josephus, looking back on his administration, did not view either Pilate or his term of office in particularly negative terms ${ }^{2}$.

It is however possible to piece together some picture of the Pilate with whom Josephus presents us. He is said to have brought the standards into

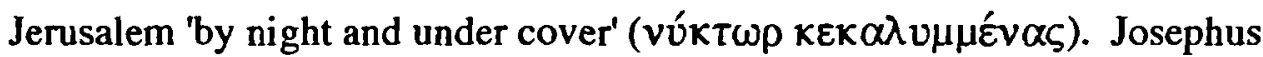
has used the reference to night before: in 1.229 Herod enters Jerusalem by night after being forbidden by Hyrcanus to bring alien troops into the city during a feast of purification; in 1.437 Herod sent Jonathan (Aristobulus) to be

\footnotetext{
${ }^{1}$ Such as his positive description of John Hyrcanus (1.68-69), or the negative ones of Albinus (2.272-276), Florus (2.277f ) and the officials Scaurus (1.132), Silo (1.291, 297ff, 302) and Sabinus (2.16ff). These men are all charged with some combination of brutality and comuption through bribery. See the similar allegations made against Pilate's character by Philo in Leg 299-305, discussed in the previous chapter. Such slurs are completely absent from Josephus' description of Pilate in the War.

${ }^{2}$ This may of course be linked to the fact that Josephus was under Flavian patronage as he wrote the War; yet he has no qualms about portraying Albinus, Florus and other Roman generals in a poor light, suggesting that Pilate would have come under similar criticism had it been necessary. Other characters such as Bacchides, Scaurus and Sabinus who play a smaller role than Pilate are subjected to a moral judgement.
} 
murdered at Jericho 'by night'. The phrase clearly indicated the perpetration of a crime, or something which would shock others were it done in daylight 1 . In his description of Pilate, therefore, Josephus wanted his readers to understand not only that Pilate' s introduction of iconic standards was against the law (which is made explicit at $\$ 170$ ) but also that Pilate knew his actions would cause offence and so took precautions to ensure that his installation of the standards was not seen by the people and to present them with a fait accompli the following morning. No motives are given for Pilate's conduct, either to blacken or to exonerate him, and it is left to the reader to form his or her own conclusions. The overriding impression however is one of insensitivity; not blatant but combined with a certain amount of stealth and secrecy, and a disregard for the religious feelings of those under his rule.

Similarly at Caesarea, Pilate is not moved by the pleas of the people to uphold their ancestral laws and refuses to remove the standards. He shows either patience or stubbornness in allowing the people to remain motionless outside his house for five days and nights. It is the reaction of the people which Josephus wants to highlight at this point rather than the psychology of Pilate but it would make sense within the narrative to see the governor expecting the people to tire of their demonstration and simply waiting for them to accept the standards and go home. The endurance of the Jews is, however, stronger than the governor had bargained for and on the sixth day he resolves to end the matter. Here again he shows the same lack of openness as he did with the introduction of the standards: he takes his seat on the tribunal with the apparent intention of answering the people, but he has no intention of discussing the matter and instead gives his soldiers a prearranged signal to surround the multitude. An important point is that the soldiers have not yet drawn their swords, though Josephus states that they were armed $(\$ 172)$; Pilate's intention was to intimidate the people into acceptance by a sudden display of troops rather than a resort to bloodshed at this stage. The War suggests that such intimidatory tactics were in regular use by Roman commanders who wished to frighten their opponents into surrender and thereby minimize bloodshed on both sides ${ }^{2}$. Pilate's actions are therefore not unusual for a Roman officer. Yet such intimidation only produced silence in the multitude and Pilate goes one step further, this time threatening to execute the people unless they accepted Caesar's standards. So far the matter has been entirely in Pilate's hands: he ordered the introduction of the standards into

\footnotetext{
${ }^{1}$ Jn 13.30 uses a similar night symbolism when Judas leaves to betray Jesus.

${ }^{2}$ For example Vespasian parades his forces before the enemy at the Galilean frontier (3.127) and at Jotapata (3.146) and Titus does the same before Jerusalem (5.348ff).
} 
Jerusalem and he has been firmly guiding the events in Caesarea, attempting to dispel the crowd without bloodshed by three means, first ignoring them, then intimidating them and finally threatening them. He has remained completely firm in his conviction that the people must accept the symbols of imperial Rome, not even entering into a discussion of the matter. The Jewish demonstration appeared to have little chance of success. But suddenly the situation changes and the reader is shown that the Jews do have the ability to change events, that a passive willingness to die and trust in God can save both them and their ancestral laws. Pilate is 'overcome with astonishment at such intense religious zeal' (

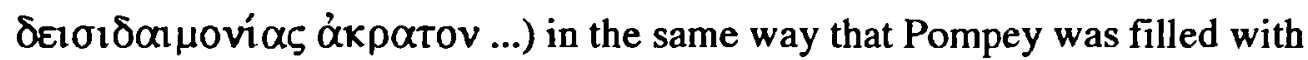
admiration for Jewish devotion during the siege of Jerusalem (1.148) or that Petronius will later be filled with astonishment and pity at the sight of the Jewish multitude ready to die rather than accept Gaius' statue ${ }^{1}$. As a result he commands that the standards be immediately removed from Jerusalem.

For Josephus, Pilate's behaviour here is no more a sign of 'weakness' than Petronius' determination to defend Jewish interests is a show of 'treason'. It was a Roman prefect's duty to preserve law and order in his province. Pilate had maintained his defiant position on the standards as long as he was able but he drew the line at the massacre of large numbers of passive unarmed protesters. In this case the symbols of Rome and personal pride were sacrificed in favour of peace in the province. The verb is active ( $k \varepsilon \lambda \varepsilon u ́ \varepsilon r$ ); Pilate is still in command of the situation. This is the first incident involving Pilate which Josephus narrates and the affair gives the impression of a new governor testing public opinion, seeing how far the Jewish people would go in defiance of their ancestral religion. Pilate backed down in this case; he is not so stubborn or self-willed that he will not heed public opinion and his amazement at Jewish willingness to die for their religion means that, for the moment, he will uphold their laws in the interests of preserving the peace.

In the second episode, Pilate is said to have 'provoked a fresh uproar'

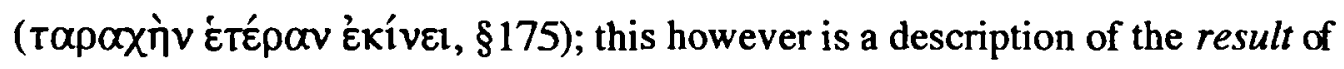
his actions, not his deliberate intention. It is not the construction of the aqueduct itself which seems to cause offence - Herod's building of one in Laodicea on Sea earns him praise from Josephus (1.422) - but the fact that he completely uses up ( $\dot{\xi} \xi \alpha v \alpha \lambda i ́ \sigma \kappa \omega v)$ the temple treasure. Josephus passes no comment on the legality of this act but it is clear from the sequel that the anger

\footnotetext{
${ }^{1}$ Much later the Romans will show the same incredulousness at Jewish fortitude when confronted with the mass suicides at Masada. This recurring theme is part of Josephus' aim to enhance the standing and piety of his people in the eyes of his Graeco-Roman contemporaries.
} 
of the people was aroused by it. It is also apparent from his prior positioning of troops that, as in the standards incident, Pilate knew that there was a high probability that the people would take offence at his actions. Again the War shows Pilate being consciously insensitive towards Jewish customs. This time he has taken precautionary measures to deal with any disturbance, yet his methods again show a concern to avoid unnecessary bloodshed. He does not parade his soldiers in an open display of aggression or intimidation which could provoke the already rioting people against Rome, but has his troops dressed in ordinary clothes and mingled with the crowd. The soldiers are armed but have orders to use only clubs and not their swords; it is only rioters who are to be beaten $(\S 176)$. In this incident it is the people who try to intimidate Pilate by 'besieging him with angry clamour' ( $\$ 175)$; only after this does Pilate give his men the agreed signal. Pilate appears to have acted appropriately in the circumstances; according to Josephus the governor was paid 'to extinguish the flames of war ... and to root out the cause of ... disorders' (2.296). Later Cumanus in a similar situation, surrounded by angry Jews and fearing for his own safety, sent for troops who used such indiscriminate violence that over 30,000 were either killed or trodden to death (2.226-227); Pilate's orders to his men, if inconsistent with the final slaughter, do not appear to have been unduly harsh. The incident involving the aqueduct ends dramatically, describing the silence of the multitude. For Josephus it is a tragic end which they have brought upon themselves by their own riotous behaviour rather than due solely to violent aggression from Pilate.

The picture of Pilate which emerges from the Jewish War therefore is one of a governor who can be consciously insensitive towards Jewish religious customs when they conflict with the interests of Rome; yet he does not quickly resort to unnecessary violence, preferring intimidation and threats in the first incident and ordering his men only to use clubs and beat rioters in the second. He takes his commission as provincial governor charged with preserving law and order seriously, in the first episode backing down rather than ordering mass executions and in the second quelling a disturbance with what should have been a minimum of violence. But he is not merely a blunt, insensitive representative of imperial Rome, he can be favourably impressed by Jewish religious devotion and allow this to affect his judgement.

Finally Pilate needs to be placed alongside other Roman governors in the War: how does he compare with them? Is he harsher or more lenient? Is there a gradual deterioration in the conduct of Roman officials posted to Judaea into which he takes his place? In answer to the last question, there does not seem to be a general decline in the administrations of subsequent 
governors according to the War; each governor is judged according to his own merits and Josephus does not seem to envisage a gradual worsening in the Roman representatives ${ }^{1}$. Only nine of the fourteen Roman governors are mentioned at all and four of them, Coponius (2.117-118), Fadus and Tiberius Alexander (2.220) and Festus (2.271), are referred to only briefly. Josephus remarks that Judas the Galilean incited his compatriots to revolt under Coponius' administration, but this is not linked with the governor's conduct. The next two Roman governors mentioned after Pilate, Fadus and Tiberius Alexander, receive a particularly favourable report: 'by abstaining from all interference with the customs of the country (they) kept the country at peace' $(2.220)^{2}$. Disturbances broke out under Cumanus but again no blame is attached to the governor for this (2.223-245). Cumanus is eventually charged with refusing to take action quickly enough in disturbances between Galileans and Samaritans and banished (2.245). Felix and Festus are credited with attacking impostors and brigands $(2.247,253-270,271)$. So far, although John founded his fourth philosophy under Coponius and the activity of brigands, sicarii and impostors have been steadily mounting from the time of Cumanus to that of Fadus (ie AD 48-62), the War lays no charges of mismanagement against the Roman govemors. With Albinus the quality of the Roman procurators changes. His administration 'was of another order' states Josephus, 'there was no villainy which he omitted to practice' and 'from this date were sown in the city the seeds of its impending fall' (2.272-276). Florus, however, made Albinus 'appear by comparison a paragon of virtue' (2.277) and Josephus specifies in detail his tyranny ( $\$ 295)$, his unprecedented cruelty $(\S \S 308,340)$, covetousness and bribery $(\$ \S 331,532)$ and how he wanted war to cover up his own atrocities ( $\$ 282-283)$. Although Agrippa in his speech (2.345-401) speaks generally of the 'insolence of the procurators' (\$348), the intolerable harshness of Roman ministers and oppressive governors (\$352), it is clearly predominantly Florus' governorship which has led the people to revolt rather than a culmination of harsh governorship (§353), as the people themselves admit in $\S 402$. The same procurator will not

\footnotetext{
${ }^{1}$ Bilde suggests that the War lays an immediate cause of the revolt at the feet of the ever poorer administration of Palestine by the Romans which led to the growth of the war party and tensions between Jews and non-Jews, Flavius, p 74. See also Rajak, Josephus, p 79; Attridge, 'Josephus', p 209. Cohen however correctly notes that only the procurators Albinus and Festus are seen as external factors in War 's description of the revolt and not a gradual disintegration of governors, Josephus, p154.

${ }^{2}$ Later, in 5.205, we learn that Tiberius Alexander's father was responsible for plating the gates of the Jerusalem temple. The ex-procurator himself continues to earn Josephus' respect as the loyal friend of Titus (5.45) entrusted with the second watch during the siege of Jerusalem (5.510).
} 
remain for ever' argues Agrippa, 'and it is probable that the successors of this one will show greater moderation on taking office' (\$354). It is therefore only the last two procurators, especially Florus, who come under harsh criticism from Josephus in the War.

Pilate's governorship belongs to a much earlier phase in Jewish-Roman relations. He is not charged with misgovernment, nor is there any reference to banditry during his time of office. Josephus' description of Fadus and Tiberius Alexander, quoted above, shows that he measures a governor by his interference with Jewish religious customs. On this score, of course, Pilate fell down twice, but seen in context there is no hint in the War that Josephus regarded Pilate's administration as particularly poor, violent, or directly playing a part in the breakdown of relations leading to the revolt.

\section{Summary}

Josephus uses two events in Pilate's governorship to strengthen the War's foremost apologetic aim: the insistence that resistance against Rome is futile, only passive acceptance of Roman rule can produce harmony amongst subject peoples. The incident with the standards has close parallels with that of Gaius' statue, in both the Jews achieved their aims by trust in God and without resort to violence. The affair of the aqueduct stands as a warning as to what the outcome will be if the Jews trust instead in aggression and riots, a policy which they eventually follow and which leads to the tragic events culminating in the destruction of the temple. Although Josephus gives no character sketch of Pilate, the governor does display certain characteristics. He can be insensitive towards the people, expecting them to be like other nations and accept the symbols of Rome; yet he can be moved by a religious demonstration and shows himself averse to excess bloodshed. He is a governor of the Roman empire intent on preserving law and order in Judaea, taking his place in the War alongside the other relatively able governors of the early period of the province.

\section{The Antiquities of the Jews}

\section{a) Purposes}

Written almost twenty years after the War, the Antiquities chronicles Jewish history 'from man's original creation up to the twelfth year of the reign 
of Nero' and 'the events which befell us Jews in Egypt, in Syria and in Palestine' (20.259)1. Josephus' later work centres upon his own race, presenting a record of its ancient and glorious history to the Graeco-Roman world. The work may have been designed as a counterpart to the Roman Antiquities of Dionysius of Halicarnassus written almost a century earlier in 7 $B C^{2}$. Josephus had specific social and political reasons for undertaking such a task. In the turbulent years after the Jewish revolt the Jews often found themselves in difficult and dangerous circumstances; his work is to counteract pagan hostility towards Judaism and false and malicious rumours concerning its origin ${ }^{3}$. Josephus writes to persuade the members of the empire to revert to their former tolerance, and even respect, towards Judaism. This theme was also present to some extent in the War but becomes dominant in the Antiquities. Josephus shows that his own race has a culture equal, even superior, to that of Rome. He stresses the antiquity of Judaism (1.16, 16.3157) and the ancient sources upon which he relies, the Hebrew scriptures (1.5, $10.218)^{4}$. He puts a special emphasis upon the Law: it is a gift from God (3.223); Moses, the law giver, is older than the gods of other nations (1.16); it is in keeping with the law of the universe (1.24); even pagans coming into contact with it recognize its power and worth ${ }^{5}$. By recording innumerable decrees and edicts from foreign rulers throughout the centuries, Josephus shows his readers that 'in former times we were treated with all respect and were not prevented by our rulers from practising our religion and our way of honouring God. And if I frequently mention these decrees, it is to reconcile the other nations to us and to remove the causes for hatred which have taken root in thoughtless persons among us as well as among them' $(16.174 f)^{6}$. The majority of these decrees come from Roman emperors and governors protecting Jewish rights not only in Judaea but throughout the whole empire ${ }^{7}$.

\footnotetext{
${ }^{1}$ Antiq 20.267 dates it to the thirteenth year of Domitian's reign and the fifty-sixth year of Josephus' own life, ie AD 93/4.

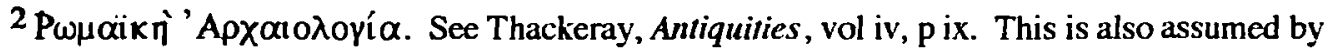
Feldman, Antiquities, vol ix, p 529 n. c and Cohen, Josephus, p 59; Rajak, Josephus, pp 48, 89.

The work is dedicated to Epaphroditus, 1.6-9 (as is the Life and Contra Apionem). For the identity of this man, see Thackeray, Antiquities, vol iv, p xi. This dedication, however, does not necessarily imply that Josephus was no longer under Flavian patronage.

${ }^{3}$ For example that recorded in 4.265-268 stating that Moses and his followers in Egypt had leprosy.

${ }^{4}$ Even arithmetic and astronomy originate with the Jews (1.166-168).

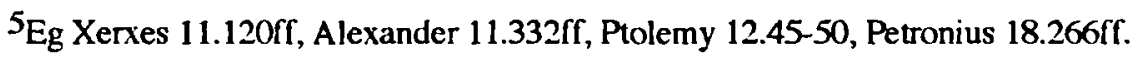

${ }^{6} \mathrm{~A}$ similar motive for recording the decrees is found in 14.185-189.

${ }^{7}$ For the decrees themselves see 11.273-283 (Artaxerxes), 12.28-31, 45-50 (Ptolemy, liberating Jewish slaves and commission of the LXX), 138-144 (Antiochus III granting Jewish
} 
By this device, Josephus shows that the revolt and its aftermath were a brief interlude in a history dominated by religious tolerance between Israel and its rulers, a state of affairs which Josephus wishes to continue.

The causes of the revolt itself receive a wider analysis in the Antiquities than in the War, which placed virtually all the blame on a group of nationalistic fanatics. Writing later, Josephus was freer to place the blame on a wider set of circumstances and people. The apologetic aim, however, remains the same: rebellion is not an innate trait of the Jewish nation but was forced on the people by a combination of internal and external factors which left them with no choice (eg 20.257). Internally the disruption caused by the 'brigands' was combined with dissension amongst the High Priests and aristocracy (20.179-181,213); King Agrippa too played his part in the decline of the country into revolt (20.216-218). Externally, a rescript of Nero annulling Jewish citizen rights in Caesarea carried the quarrel between Jews and their Greek neighbours further until it eventually kindled the flames of war (20.184). Pagan troops from Caesarea and Sebaste were also influential in arousing hostilities (19.366). By continually offending against the Jewish law the Roman governors are implicated in the rise of brigandage and play a much more significant part in the country's descent to revolt in the Antiquities than in the War. In this way, Josephus shows that the Jewish people were led into the revolt by forces outside their control ${ }^{1}$.

No account of Judaism could be simply historical or political; it had at the same time to be theological and religious. Behind the Antiquities lies the firm Jewish principle that God guides his people throughout history in accordance with his law ${ }^{2}$. Linked with this is the conviction that the Jews should passively put their trust in God, and not attempt to alter his divine plan by resorting to arms. The accounts of Gaius' statue and Pilate's standards, as in the War, illustrate this (18.266ff, 55-59). But more dominant throughout the narrative is a strong OT or deuteronomistic conception of guilt and fate in which the pious are rewarded whilst the unrighteous who do not obey God's law are punished. This was present in the War to a limited extent but becomes a fundamental theme in the present work $^{3}$. Right at the introduction to the

privileges), 417-418, 15.185-267 (Rome's treatics with the Jews, decrees from Julius Caesar, Dolabella in Asıa, Lentulus in Ephesus, Delos, Pergamum, Halicarnassus, Sardis, Ephesus), 306-322 (Mark Antony), 16.162-165 (Augustus' decree in favour of Jews in Asia), 167-170, $171,172-173$ (Marcus Agrippa to the Ephesians and Cyrenaeans), 19.280-285, 286-291 (Claudıus to Alexandria and Syria, protecting Jewish rights finally to the whole world).

${ }^{1}$ See Cohen, Josephus, p 155.

2 In this Josephus refuses to acknowledge Epicurean philosophy which excludes Providence, 10.277fr.

${ }^{3}$ Eg War 1.81-4, 113, 179, 357, 531, 581, 596, 656, 4.297, 7.32, 451ff. 
book, in 1.14, Josephus states that the lesson to be drawn from Antiquities is that 'men who conform to the will of God, and do not venture to transgress laws that have been excellently laid down, prosper in all things beyond belief, and for their reward are offered by God felicity; whereas, in proportion as they depart from the strict observance of these laws, things (else) practicable become impracticable, and whatever imaginary good thing they strive to do ends in irretrievable disasters' and in 1.20 Moses stresses that God 'grants to such as follow Him a life of bliss, but involves in dire calamities those who step outside the path of virtue' 1. Characters such as Abraham (1.256), Isaac (1.346), Jacob (2.196), Moses (4.177, 312-331), Joshua (4.117-119), Gideon (5.232), Asa (8.314), Jehoshaphat (8.393-394), Hyrcanus (13.299-300), Zamaris (17.29-31), Izates of Adiabene (20.46-48) and others are praised for their piety and righteousness towards God and are rewarded by long lives and prosperity. Characters who transgress the law, however, do not escape punishment. The Sodomites were condemned to destruction (1.194-195, 202203), the insolent Hebrews in the wilderness were made to wander for forty years (3.31 1ff), Saul's reign was cut short because he neglected God (6.104, 141-151, 334-336, 378) and Solomon died ingloriously for his abandonment of God's laws (8.190ff). Haman plotted the destruction of the whole Jewish race and deserved his ironically just end (11.209-269), similarly Antiochus Epiphanes (12.248-359) and the emperor Gaius (18.306, 19.1-113). Agrippa accepted his acclamation as a god and was struck down by divine vengeance $(19.343-352)^{2}$. It is not only individual characters but the whole Jewish race who are warned that afflictions would come upon them should they transgress God's law ${ }^{3}$.

Josephus' Antiquities therefore extols the long and distinguished history of his race and the importance of its divine Law: these facts, long recognized and held in esteem by pagan overlords, should commend Judaism to Josephus' pagan readers. The Jewish nation is under God's protection and anyone who shows insolence and impiety towards its laws, whether a Jew or pagan, risks divine vengeance.

\section{b) Pilate in the Antiquities of the Jews}

\footnotetext{
${ }^{1}$ See also 2.28, 107, 6.307, 8.314, 18.127-129.

${ }^{2}$ Sce for example Dathan who perishes in an earthquake (4.51-53), Korah who is burnt (4.5458), Zanbrias and 14,000 others (4.150-155), Achar (5.33), the Shechemites (5.250), Abimelech (5.233fn), Eli's iniquitous sons (5.338-340, 358), Nabal (6.305-307), Joab (8.1316), Jadon (8.240), Rchoboam $(8.251 \mathrm{ff}, 270,289)$, Ahaziah (9.18-21), and many others.

${ }^{3}$ Eg 4.312ff, 5.179-180, 185, 200, 6.305, 8.314.
} 
The Antiquities contains four narratives involving Pilate. The first

two, concerning the standards and the aqueduct, were also found in the War.

These are followed by an incident concerning Jesus 'a wise man' and one involving Samaritans which culminated in Pilate's departure to Rome on the orders of Vitellius. These last events have no parallel in the War. The texts are as follows ${ }^{1}$ :

\section{Antiq $18.55-64$}

Now Pilate, the procurator of Judaea, when he brought his army from Caesarea and removed it to winter quarters in Jerusalem, took a bold step in subversion of the Jewish practices, by introducing into the city the busts of the emperor that were attached to the military standards, for our law forbids the making of images. It was for this reason that the previous procurators, when they entered the city, used standards that had no such ornaments. Pilate was the first to bring the images into Jerusalem and set them up, doing it without the knowledge of the people, for he entered at night. But when the people discovered it, they went in a throng to Caesarea and for many days entreated him to take away the images. He refused to yield, since to do so would be an outrage to the emperor; however, since they did not cease entreating him, on the sixth day he secretly armed and placed his troops in position, while he himself came to the speaker's stand. This had been constructed in the stadium, which provided concealment for the army that lay in wait. When the Jews again engaged in supplication, at a pre-arranged signal he surrounded them with his soldiers and threatened to punish them at once with death if they did not put an end to their tumult and return to their own places. But they, casting themselves prostrate and baring their throats, declared that they had gladly welcomed death rather than make bold to transgress the wise provisions of the laws. Pilate, astonished at the strength of their devotion to the laws, straightway removed the images from Jerusalem and brought them back to Caesarea.

He spent money from the sacred treasury in the construction of an aqueduct to bring water into Jerusalem, intercepting the source of the stream at a distance of 200 furlongs. The Jews did not acquiesce in the operations that this involved; and tens of thousands of men assembled and cried out against him, bidding him relinquish his promotion of such designs. Some too even hurled insults and abuse of the sort that a throng will commonly engage in. He thereupon ordered a large number of soldiers to be dressed in Jewish garments, under which they carried clubs, and he sent them off this way and that, thus surrounding the Jews, whom he ordered to withdraw. When the Jews were in full torrent of abuse he gave his soldiers the prearranged signal. They, however, inflicted much harder blows than Pilate had ordered, punishing alike both those who were rioting and those who were not. But the Jews showed no faint-heartedness; and so, caught unarmed, as they were, by men delivering a prepared attack, many of them actually were slain on the spot, while some withdrew disabled by blows. Thus ended the uprising.

\footnotetext{
${ }^{1}$ Taken from Feldman, Antiquities (Loeb), vol ix, pp 43-51, 61-65.
} 
About this time there lived Jesus, a wise man ... When Pilate, upon hearing him accused by men of the highest standing amongst us, had condemned him to be crucified, those who had in the first place come to love him did not give up their affection for him. ...

\section{Antiq $18.85-89$}

The Samaritan nation too was not exempt from disturbance. For a man who made light of mendacity and in all his designs catered to the mob, rallied them, bidding them go in a body with him to Mount Gerizim, which in their belief is the most sacred of mountains. He assured them that on their arrival he would show them the sacred vessels which were buried there, where Moses had deposited them. His hearers, viewing this tale as plausible, appeared in arms. They posted themselves in a certain village named Tirathana, and, as they planned to climb the mountain in a great multitude, they welcomed to their ranks the new arrivals who kept coming. But before they could ascend, Pilate blocked their projected route up the mountain with a detachment of cavalry and heavy-armed infantry, who in an encounter with the firstcomers in the village slew some in a pitched battle and put the others to flight. Many prisoners were taken, of whom Pilate put to death the principal leaders and those who were most influential among the fugitives.

When the uprising had been quelled, the council of the Samaritans went to Vitellius, a man of consular rank who was governor of Syria, and charged Pilate with the slaughter of the victims. For, they said, it was not as rebels against the Romans but as refugees from the persecution of Pilate that they had met in Tirathana. Vitellius thereupon dispatched Marcellus, one of his friends, to take charge of the administration of Judaea, and ordered Pilate to return to Rome to give the emperor his account of the matters with which he was charged by the Samaritans. And so Pilate, after having spent ten years in Judaea, hurried to Rome in obedience to the orders of Vitellius, since he could not refuse. But before he reached Rome Tiberius had already passed away.

\section{Context}

The references to Pilate in the Antiquities occur in book 18, a section which parallels book 2 of the War but with a great deal of extra material, either in the form of fuller details or additional stories. Josephus gives a fuller description of the early prefects: he mentions a disturbance caused by Samaritans under Coponius (18.29-30); Ambivulus (18.31) and Rufus (18.32) 
are mentioned though no internal events from their governorships are recorded; and the four high priests deposed by Gratus are listed (18.33-35) ${ }^{1}$. Pilate is first referred to in 18.35 as Gratus' successor but a description of Antipas' building of Tiberias (18.36-38), Parthian affairs and the death of Germanicus intervene before the events of Pilate's governorship are returned to in $18.55 \mathrm{ff}$. The narrative at this point therefore is not focused exclusively on Judaean affairs as was the case in the parallel section of the $\mathrm{War}^{2}$. The record of Pilate is followed by several events involving Vitellius who, like Petronius his successor as Syrian legate, receives a favourable report from Josephus (eg 18.90, 121ff) ${ }^{3}$.

The report of Pilate is structured as part of a series of five disturbances ( $\theta$ óp $\beta$ ßor) or events which broke out simultaneously amongst Jews in Judaea and Rome and amongst the Samaritans, followed by Pilate's removal from office by Vitellius. The first three occurred in Judaea - Pilate's introduction of standards, his building of the aqueduct, and his execution of Jesus 'a wise

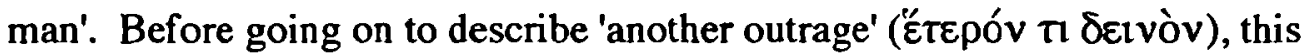
time in Rome, Josephus first pauses to relate a scandal involving Isis worship in the city, the sensational and erotic quality of which probably appealed to his keen sense of the dramatic ${ }^{4}$. Returning to the promised 'outrage', Josephus recounts an incident involving Jewish embezzlers and Tiberius' expulsion of all the Jews from Rome. The final line of this story underlines Josephus' apologetic interest: 'and so because of the wickedness of four men the Jews were banished from the city' (18.84); clearly he wants his readers to understand that the (possibly well-known) expulsion of the Jews under Tiberius was not because of any suspect practices or disturbances caused by Jews in general but, rather unjustly, all on account of four men ${ }^{5}$. The final

\footnotetext{
${ }^{1}$ Preserving a record of the line of High Priests who served during a length of 2,000 years was one of Josephus' aims (20.261); see a similar list in 10.151-153.

${ }^{2}$ The Antiq devotes a considerable amount of space to important events outside Palestine, in the empire and Parthia, for example 18.39-52 (Parthian wars), 18.53-54 (the death of Germanicus), 18.96-105 (clash between Rome and Parthia). One reason for this may be because of the size and importance of the Jewish community in Babylonia, which was now subject to the Parthians; see Feldman, Antiquities, vol iv, pp 32-33, n. b. Cohen less convincingly regards these events as 'extraneous', inserted only in order to provide enough matenal for the Dionysian twenty books; Josephus, p 59.

For a detailed analysis of the way in which Josephus structures his material in the Antiq see Schwartz 'Pilate's Appointment', pp 185-198.

${ }^{3}$ Pilate is referred to again briefly in 18.177 , a passage mentioning only that Gratus and Pilate were the only govemors appointed to Judaca under Tiberius.

${ }^{4}$ See Cohen, Josephuss, p 90 for Josephus' literary style. Such features are common in Hellenistic novel writung, see Bilde, Flavius, p 98.

${ }^{5}$ The expulsion of both Jews and adherents of Egyptian cults under Tiberius is similarly linked by Tacitus, Ann 2.85; if both did occur at the same time, this would explain why Josephus links these two stories. Suetonius, Tib 36 and Dio 57.18.5a also mention the
} 
disturbance describes how Pilate put down a Samaritan uprising, followed by Vitellius' intervention and Pilate's dismissal.

\section{Apologetic Themes behind the Pilate Narratives in Antiquities}

The verbal reminiscences between the whole of Antiq 18-20 and its earlier parallel ( War 2.117-118, 167-279) are extraordinarily small, suggesting that Josephus was not simply adding extra details to his previous account but has completely rewritten the entire section giving certain themes a different emphasis 1 . The incidents involving the standards and the aqueduct too are far from duplicates of their parallels in the $W a r(2.169-177)$; both contain certain additions and reductions which give a different slant to the portrayal of Pilate's character. Each of the incidents narrated in the later book show Pilate in a different light; either he is at the forefront of attention or he acts as a foil to highlight other characters or themes within the story. Each event displays one or more of the apologetic aims characteristic of the Antiq as a whole.

A comparison of the standards incident in the Antiquities and the War reveals several important changes.

1) The events in Pilate's administration are not introduced so abruptly as they were in the War. The precise dates of Pilate's arrival and departure are given along with the length of his governorship ${ }^{2}$; the whole of Pilate's contact with Judaea is therefore described much more fully in the Antiquities.

2) A second important difference is the amount of space devoted to Pilate's crime and the Jewish reaction. In the War, Pilate's crime is narrated briefly whilst the Jewish reaction is recorded in detail: of the 31.5 Greek lines (in the Loeb edition) of the War, 3.5 are devoted to Pilate's crime and 9 to the

expulsion of Jews from Rome under Tiberius. The historical reason for the expulsion appears to have been that the Jeus were too active in proselytism, see Feldman, Antiquities, vol ix, p $60 f, n$. a. The expulsion appears to have occurred in AD 19 (Tacitus, Ann 2.85), not some time betw een AD 26 and 36 as Josephus' narrative implies (18.65). The majority of scholars assume that Josephus is simply mistaken in his chronology at this point. Smallwood for example suggests his dating is occasioned by the recollection of Sejanus' hostility towards the Jek s at this ume, 'Some Notes', p 326; yet the whole assertion of Sejanus' anti-Semitism, which is only recorded by Philo, is suspect; see Hennig, Seianus, pp 160-179. Schwartz argues for the chronological accuracy of this reference: following Eisler he suggests that Pilate came to office in AD 19 ('Pilate's Appointment', pp 182-201). It may be, how ever, that Josephus has deliberately left his record of the Jewish expulsion from Rome until Pilate's time so that he can group all his 'disturbance stories' together, giving a much stronger effect of attacks on Jews breaking out simultaneously throughout the empire than would have been achieved by inserting the story in its correct chronological place.

${ }^{1}$ This has been demonstrated by Cohen, Josephus, pp 58-65; he writes, 'the natural assumption of contunual and detailed consultation of BJ by AJ is unjustified' ( $p$ 65).

218.35, 89. For Eisler's view that these dates were due to later Christian interpolators in the time of Maximin Daia see chapter 1. 
initial Jewish reaction. In the Antiquities, however, the situation is reversed: of 28.5 lines 11 describe Pilate's crime whilst only 3 give the initial Jewish reaction ${ }^{1}$.

The description of Jewish activities around Pilate's residence in Caesarea is also shorter in the Antiquities, nor does it give the same impression of almost inhuman passivity. Whilst the $W a r$ records that the people 'fell prostrate around his (Pilate's) house and for five whole days and nights remained motionless in that position' (2.171), Antiq states only that 'for many days (they) entreated him to take away the images' and then 'they did not cease entreating him' ( $\$ 57)$. Later Pilate urges the throng to 'put an end to their tumult' (Oopvßriv), again implying that in the Antiquities account the Jewish crowd have not been entirely passive in Caesarea. The exchange between Pilate and the Jews on the sixth day in Caesarea has also been reduced in the Antiquities; Pilate's three-fold escalation of aggression in the War (the introduction of the troops, threats and the drawing of swords) has been amalgamated into one action (18.58); consequently the note in the War that the people were struck dumb by the initial appearance of the soldiers has dropped out.

3) The structure of cause and effect which was so prominent in the War has been considerably toned down in the Antiquities.

The cumulative effect of these details is that it is no longer the Jewish reaction which primarily engages the reader's attention. Although the Jewish willingness to die rather than to transgress ancestral law is still a dominant motif, Pilate himself has become much more important, both his activities and motivation.

This ties up with the interest in the Antiquities not only in national history but in the personal histories of individuals who played a part in shaping the nation's fortunes ${ }^{2}$. In this incident therefore Josephus shows an interest in Pilate as an historical man and Roman governor. In particular his attitude to the Jewish law is important; an attitude which, in common with other characters in the Antiquities, will ultimately determine his fate.

The account of the aqueduct similarly shows different emphases compared to the same account in the War.

\footnotetext{
'By mov ing up the phrase 'for our law forbids the making of images' in Antiq, Josephus has made it into an enlargement upon Pilate's crime rather than an explanation of the people's outrage.

${ }^{2}$ For example the stories of King Izates of Adiabene and his mother Helena (20.17-48) or the death of Gaus (19.113).
} 
1) The strong sequence of cause and effect has again been minimized, suggesting that the actions and reactions of the central characters are no longer of central significance.

2) Unlike the standards episode, Pilate appears in a better, or at least more neutral, light in this incident. He is still insensitive towards Jewish customs but Josephus does not ascribe this to deliberate malice or an attack on Judaism as in the previous episode. He is said to have spent ( money from the sacred treasury, rather than using it up entirely as the War suggests. In the Antiquities it is the sight of the angry mob which induces Pilate to send in his troops whereas in the War they were already in position, implying that Pilate had expected trouble. Again in the Antiquities Pilate gives the people a chance to withdraw after he has secretly stationed his men; such an offer was lacking in the War. The ensuing slaughter in the Antiquities is blamed not so much on Pilate as the troops who 'inflicted much harder blows than Pilate had ordered, punishing alike both those who were rioting and those who were not' $(\S 62)$.

3) The angry demonstration of the people in the War has also been toned down in the Antiquities. The precise cause of the Jewish objection is again expressed in fairly vague terms and tens of thousands are said to have assembled and attempted to persuade him to discontinue his plans. Josephus

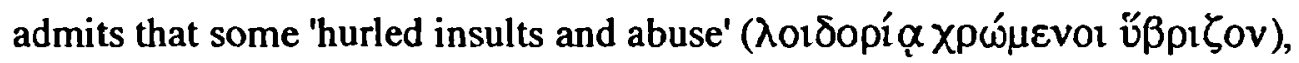
though he tempers this by adding that it was only the sort of thing that throngs commonly engage in. Faced with the ensuing massacre, Josephus states, the Jews 'showed no faintheartedness'. They were 'caught unarmed' whilst their opponents were 'delivering a prepared attack'. Some were slain on the spot (obviously unable to defend themselves); others withdrew because of their injuries. There is no reference to people trodden to death by their compatriots in the ensuing flight as in the War. All the dead and injured are victims of the aggression of the troops, an aggression which apparently overstepped Pilate's intentions.

These alterations mean that the central feature of this story in the Antiquities is not so much Pilate's crime or the Jewish uproar, as in the War, but the attitude of the Jews faced with a vicious attack from the pagan auxiliary troops. This fits in with an apologetic tendency within the Antiquities: Josephus regards the harshness and bias of the non-Jewish troops at the governors' disposal as one of the contributing factors in the revolt. This particular incident gives the first indication under direct Roman rule of future 
friction between the troops and the people ${ }^{1}$. Secondly, the courage of the Jewish people faced with such brutality is praised, thereby fulfilling the Antiq's major apologetic aim of commending the nation to Josephus' readers.

In this incident Pilate has retreated from significance. He plays an important role in initiating the conflict by appropriating temple funds but he quickly retreats to allow the fortitude of the Jews and aggression of the troops to take centre stage. Little attention is paid to Pilate's character here, his actions serve primarily to illustrate Josephus' apologetic interests concerning the Jewish people and the Roman troops in the Antiquities.

The third episode, involving 'Jesus, a wise man', or the Testimonium Flavianum, has no parallel in the War. Unfortunately the whole passage appears to have suffered at the hands of later Christian interpolators and the original wording of this section is now lost ${ }^{2}$. Given the context, the original text probably recorded another disturbance in the time of Pilate, this time centring on Jesus or his followers after his death. Whatever the original, the present text adds little to the picture of Pilate in the Antiq. The centre of attention is Jesus and his followers, Pilate is referred to only briefly.

The final narrative centres on a Samaritan disturbance, again an event which has no parallel in the War. The central elements in this event are the activities of the Samaritans and their unnamed leader, a man 'who made light of mendacity and in all his designs catered to the mob'. Throughout the Antiquities the Samaritans receive a poor press; they regarded the Jews with 'feelings of hostility and envy' (11.114-119) and the land of Samaria is constantly seen as the place of apostate Jews and law-breakers (eg 11.306, 340ff, 346) who acknowledge Jewish kinship when the Jews are prospering but deny it in times of Jewish ill-fortune, such as the persecution of Antiochus Epiphanes (12.257-264) ${ }^{3}$. In the present scene despite Josephus' slanderous

\footnotetext{
${ }^{1}$ See later $19.356-366$, especially $\$ 366$ where Josephus explicitly states that these troops were a source of great disasters to the Jews and later in Florus' time sowed the seeds of war. Also 20.176 .

2 On this passage and the problems which it raises see Baras Testimonium', pp 338-348. Bibliography in Feldman, Antiquities, vol ix, pp 573-575.

${ }^{3}$ For Josephus' description of their origins see 9.288-291. After the Jewish return from the Babylonian exile, the Samaritans attempt to hinder the reconstruction of the Jerusalem temple (11.19-30, 83ff, 97ff); and at first refused to pay tribute for sacrifices in Jerusalem (12.156). The Samaritan temple was built in the time of Alexander the Great, with a 'law-breaker', Manasses, as its High Priest (11.306). According to Josephus, the Samaritans were quick to dedicate this temple to Zeus Hellenios in the time of Antiochus Epiphanes (12.257-264). During a dispute between Jews and Samaritans over which temple had been built according to Mosaic laws, king Ptolemy Philometor decided in favour of the one in Jerusalem. The Samaritan temple was eventually destroyed by Hyrcanus (13.254-256).
} 
characterization of its leader, the project initially sounds like a relatively harmless religious expedition. Yet the people appear in arms ( $\varepsilon$ o ó $\pi \lambda 01 \zeta)$, they assemble at a village and accept many new arrivals ( $\$ 86)$. The exact intentions of the Samaritans therefore, including what they planned to do with the vessels once they had found them, become more sinister. That their gathering at Mount Gerizim did in fact have political implications is half admitted by the Samaritan council in front of Vitellius in the sequel (18.88). This event confirms the already established picture in the Antiquities of the Samaritans as a devious, untrustworthy and self-seeking nation. This denigration of the Samaritan nation in the Antiquities is probably linked with Josephus' praise of his own Jewish nation and a reflection of contemporary Jewish prejudices against their northern neighbours ${ }^{1}$.

Pilate again retreats into the background in this incident: he is depicted as a competent Roman governor putting down a messianic gathering which threatened to disrupt law and order without undue force and executing its leaders.

The Samaritan disturbance contains a sequel describing Pilate's return to Rome. Although this is linked chronologically to the Samaritan incident, it is also a sequel to Pilate's administration generally and his actions with the standards in particular. It is only in the standards incident that the Antiquities pays much attention to Pilate himself; there he is portrayed as bent on destroying the Jewish law by his innovative attempt to introduce standards into Jerusalem. Throughout the last three incidents Pilate has receded into the background whilst other issues or apologetic aims come to the fore. Yet the narrative of the Antiquities has repeatedly stressed that an unpleasant fate awaits those who attempt to tamper with the Jewish law. It is only now, ordered to Rome by Vitellius, that Pilate is called to account for his crimes, not primarily against the Samaritans but against Jewish ancestral customs ${ }^{2}$.

The council ( $\beta \circ \cup \lambda \grave{\eta})$ of the Samaritans complained to Vitellius, the legate of Syria, about Pilate's slaughter of Samaritans at Mt Gerizim. They

\footnotetext{
'On an anti-Samaritan polemic within Judaism see Haacker 'Samaritan' in DNTT, vol 3 pp 449-467; Montgomery, Samaritans, p 156. See also the NT, esp Mt 10:5f, Lk 9:51-56, 10:3037 (Good Samaritan), 17:11-19.

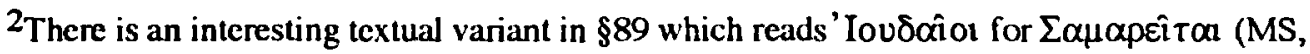
MWE Lat, see Feldman, Antiquities, vol ix, p 64, $n$ 1). This would have Pilate sent to account to the emperor regarding matters with which he was charged by the Jews. Although this does not fit the context and clearly it is the Samaritans who are meant, the textual variant gives the correct 'theological sense'. For Josephus it is because of his crimes against the Jewish nation and its law that Pilate loses his position and only incidentally because of a dispute with the Samaritans.
} 
declared that 'it was not as rebels against the Romans but as refugees from the persecution ( $\dddot{v} \beta \rho \varepsilon \omega \varsigma$ ) of Pilate that they had met in Tirathana' ( $\$ 88$ ).

Throughout Josephus' narrative, the Samaritans have been portrayed as selfseeking and duplicitous. There is therefore no reason to suggest that Josephus sees their present words as the real explanation behind the uprising, or expects his readers to do so. Yet the reference to $u ̈ \beta \rho \varepsilon \omega \varsigma$ is significant. The related word $u ̈ \beta p 1 \varsigma$ is often used in Jewish literature of one who will incur God's wrath and suffer divine retribution 1 . Its use recalls Pilate's outrage against the law and the disruption caused by the standards, an act which leaves Pilate liable to retribution.

Vitellius, who receives a great deal of praise in the Antiq, 2 is to some extent the unconscious agent of retribution in his handling of the affair. Without further investigation he dispatches Marcellus to Judaea and orders Pilate to Rome to account for himself before Tiberius. This Pilate had no option but to obey and hurried to Rome. The subsequent fate of Pilate is left untold. Josephus notes only that Pilate reached Rome to find Tiberius already dead. Gaius, his successor, 'devised countless attacks upon the equites' (to which social group Pilate belonged), 'he deprived (them) of their privileges and expelled them from Rome or put them to death and robbed them of their wealth' (19.3). Whatever happened to Pilate, he did not return to Judaea and Marullus is sent to replace him (18.237). Pilate's departure therefore fits into the Antiquities' deuteronomistic conception of guilt and fate and the punishment which impious behaviour incurs.

The description of Pilate's administration in the Antiquities therefore highlights many important apologetic themes in the work as a whole. Most prevalent is the interest in personal histories and the divine punishment to which the impious are exposed. The courage and devotion to ancestral law of the Jewish nation is also emphasized, as is the part played by pagan troops in the breakdown of Jewish-Roman relations and Josephus' negative portrayal of the Samaritans.

\section{The Characterization of Pilate in the Antiquities}

\footnotetext{
ISee the chapter on Pilate in Philo.

${ }^{2}$ See 18.90\%, 121-123.
} 
Since Pilate retreats to some extent from a central position in the Antiquities' account of the aqueduct, Jesus and the Samaritans, we should expect to find his character described most fully in the first incident, that concerning his introduction of standards into Jerusalem. In this event Pilate himself comes to the fore and his character and motivation are described.

Most importantly he is shown as acting against the Jewish law: he

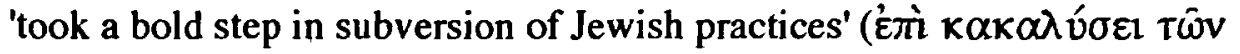

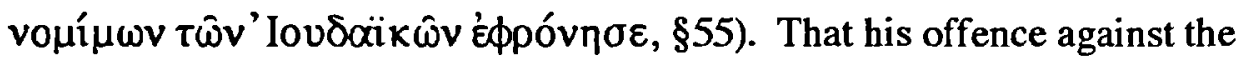
Jewish law was conscious and premeditated is shown by the use of the verb $\phi p o v e ́ \omega$, which suggests 'meaning/intending to do something', and by the fact that he set them up at night, without the knowledge of the people ( $\$ 56)$. Clearly he was aware of the important step which he was undertaking. Josephus stresses that 'our law forbids the making of images', an assertion which his narrative has stressed on many occasions ${ }^{1}$. He also emphasizes the novelty of Pilate's innovation: 'the previous governors, when they entered the city, used standards that had no such ornaments. Pilate was the first to bring the images into Jerusalem and set them up'. Pilate in the Antiquities therefore consciously and deliberately breaks the Jewish law by introducing standards with effigies of Caesar into Jerusalem, an act which no previous governor had dared to do.

By introducing the standards Pilate is compared unfavourably with preceding governors and aligns himself with other characters who attempted

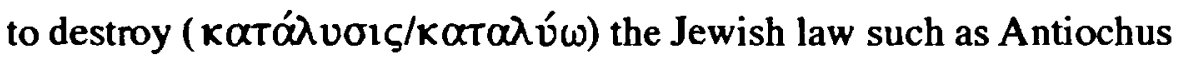

\footnotetext{
${ }^{1}$ In his descnption of the decalogue (3.91fn, Josephus notes that the 'second commands us to make no image of any living creature for adoration', similarly in 15.274, 329 and the statue of Caesar in the sy nagogue at Dora in 19.300ff. This is widened in Josephus' description of Herod's eagle: no longer is it only images for worship which are unlawful but the setting up of any images or dedications in the likeness of any living creatures (17.151). To reinforce his clarms Josephus omitted any reference to the golden calf in the wilderness or the cherubim on the curtain in Solomon's temple. Solomon is sald to have sinned by setting up images of bronze bulls to $\mathrm{x}$ hich offenngs were made and lions around his throne (8.190f). After the episode a th Pilate, the Jeu s tell Vitellius that it is contrary to their law against images for him to bring his standards through Judaea at all and the legate accordingly changes his route (18.121f). This seems a little odd since the Jews were apparently happy for Pilate's offending standards to be in Caesarea and such regiments must have been able to pass through the country; perhaps it was the particular route which Vitelluus had proposed which caused offence.
} 
Epiphanes who would destroy the temple, Herod $\mathrm{I}^{1}$ or, later the people of Dora who attempted to place Caesar's statue in the synagogue ${ }^{2}$.

In the Antiquities Pilate gives a reason for his refusal to remove the standards: 'to do so would be an outrage (i̋ $\beta \rho 1 \zeta)$ to the emperor' ( $\$ 57)$.

Although Josephus does not condemn due honour being shown to the emperor it must not impinge upon or supersede honour shown to God and his laws ${ }^{3}$.

The rest of the narrative concerning the standards in the Antiquities describes a clash between Pilate's stubborn and aggressive determination to honour

Caesar, irrespective of Jewish sensitivities, and the determination of the Jews not to allow the governor to jeopardize the peace of the nation by transgressing the law. Pagan innovations could involve the whole nation and not just the perpetrator in divine retribution and so it was worth suffering, even dying, in an attempt to prevent them ${ }^{4}$. By their calm trust in God the Jews demonstrate the supremacy of their ancestral religion.

Pilate makes no attempt to reason with the crowd or remove their religious sensitivities. His answer to the Jewish petition is aggression. Although Pilate takes the magisterial seat ( $\beta \hat{\eta} \mu \alpha, \S 57)$, Josephus records no attempt at dialogue. Instead the prefect has already concealed troops in the stadium. Nor is there a gradual escalation of intimidation in the Antiquities account such as was the case in the War. Pilate resorts to outright intimidation faster, surrounding the crowd with his troops and threatening them with death.

In exactly the same way as in the War, Pilate is astonished at the strength of Jewish devotion to their laws. Yet the effect of the change in Pilate is intensified in the Antiquities account. The man who would have

\footnotetext{
'There are close sımulantues betw een Plate's actions here and an incident in the reign of Herod I recounted in 15.267-291 in u hich the king introduced games into Judaea and decorated the theatre in Jerusalem $u$ ith $u$ ar trophies. In the belief that these trophies were images surrounded by w eapons, the people w ere extremely angry. Even when the trophies were dismantled and show $n$ to contain no images, however, a group of Jews formed a conspiracy agaunst Herod in the behef that his violation of their national customs would bring disaster upon the $a$ hole nation.

${ }^{2}$ Anuochus (12.322), Herod $(15.274,281,388,16.1)$, the opponents of the Jews in Ionia (1637), the people of Dor (19.301). The verb kata 1 úw is most of ten used in Josephus to refer to the overthrou of empires, eg 2348, 10.30,74,108,113,208,248, 11.335,337, 12.1, 19.173 (Juhus Caesar destroy ing democracy).

3 In his descripuon of Herod l's reign, Josephus shows that by flattering the emperor and influenual Romans (here by founding citues and temples) Herod was forced to depart from the cuskoms (of the Jew s) and to alter many of their regulations' (15.328). After they have pulled down Herod's cagle, Judas and Matthias tell Herod that it is less important to observe his decrees (here specifically accepting the Roman eagle above the temple) than the laws given by God to Moses. Later, Petronus felt a simılar tension, this time between following the orders of the emperor (Gaus) and respecting Jewish customs, 18.265f. The Jews reply that by unansgressing the law they would incur God's severe wrath - and He even in your eyes must be accounted a hugher power than Gaus' (\$268).

tSee $15280 \pi$.
} 
subverted Jewish practices and put down Jewish resistance by force is suddenly astounded by the strength of Jewish religious feeling. The active

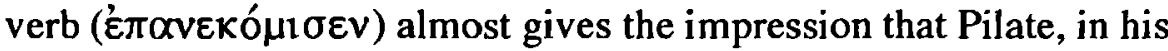
amazement and haste to rectify his actions, removed the standards himself ${ }^{1}$.

Yet Pilate's amazement at the people's devotion is short-lived; in the very next episode he again openly treats Jewish religious sensitivities with contempt by his use of temple funds for the aqueduct. To his credit, however, he did not intend the slaughter which ensued.

In the following two narratives, Pilate is faced with two uprisings not directly caused by his own actions. Acting on accusations formulated by 'men

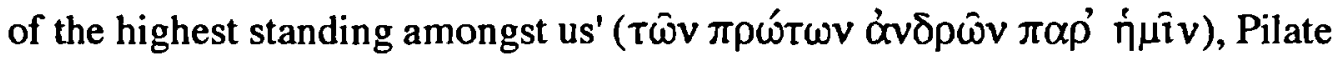
condemned Jesus to crucifixion ( $\$ 64)$. The governor appears to be competently putting down some kind of uprising by executing its leader. $\mathrm{He}$ handles the Samaritan uprising in a similar way. Given the armed nature of the gathering it is hardly surprising that Pilate takes preventative measures, blocking the projected route to the mountain summit with a detachment of

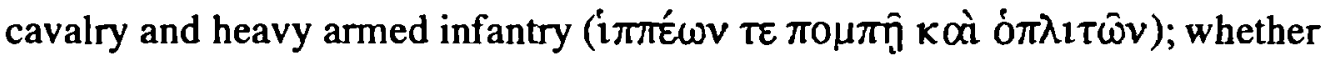
the prefect himself is actually present is not clear. This time the actions of the troops are not over-aggressive; they slay some and put others to flight. Pilate's subsequent actions too appear perfectly reasonable and restrained; only the principal leaders and the most influential are executed.

Although Pilate is portrayed as a competent governor unwilling to use an undue amount of force in maintaining peace in his province in the last two episodes, his dominant characterization in the Antiquities derives from the first episode where he is shown as deliberately acting against the Jewish law.

Finally, how does Pilate in the Antiquities compare with other Roman governors? As noted earlier, all the Roman governors from Pilate onwards are portrayed in a poorer light in the Antiquities than the War, probably owing to the absence of Josephus' imperial patrons. They play an important part in the gradual disintegration of the country into revolt. They are implicated in the rise of brigandage in the Antiq to a far greater extent than in the War, although the weightiest guilt still lies with Florus (18.95). In particular, none are said to have abstained from interfering with the country's laws, as was the case with Fadus and Tiberius Alexander in War 2.220. Cuspius Fadus attempted to compel the people to hand the high-priestly vestments over to Roman custody

\footnotetext{
${ }^{1}$ In War, Pilate gives orders for the removal of the standards.
} 
(20.6ff); Tiberius Alexander (a one-time Jew) did not stand by the religious practices of his people (20.100), possibly this has some connection in Josephus' mind with the famine which occurred during his governorship (20.101). Cumanus too receives a poorer report. He is said to have been bribed by the Samaritans not to intervene in their quarrel with their Jewish neighbours (20.118-125). Some of the bolder members of the passover crowd said that the blasphemous insult of the soldier had been prompted by the governor (20.105-112) ${ }^{1}$. Felix married a Jewess named Drusilla, by which she was breaking the law (20.141-144). Already during his governorship matters were going from bad to worse with the land infested with brigands and impostors (20.160). The governor added to the general deterioration by bribing the sicarii to have the High Priest Jonathan murdered. When this act went unpunished, the brigands slaughtered with 'perfect impunity' (20.160166). Josephus sees a link, even at this relatively early stage, between the impious acts of the brigands, left to run riot by Felix, and God's bringing the Romans to purify the city (20.166). By 20.180 Felix's administration had sunk to such a level of corruption that it was 'as if no one was in charge of the city'. Festus, on his arrival found the city still devastated by brigands (20.185-187). He ordered the Jews to pull down a wall which they had built to prevent the activity of the temple priests from being seen from Agrippa's palace but was prevented by Nero who on this occasion upheld the Jews ( $\S 193-196)$. The only procurator who is described in better terms in the Antiquities is Albinus. $\mathrm{He}$ is said to have released many prisoners 'for a personal consideration' before he left, so infesting the land with brigands; but in general his character is not described in such negative terms as in War 2.272-276. Perhaps the reason for this lies in the fact that in the War Josephus places the blame only on the last two governors, Albinus' governorship therefore has to herald a sudden deterioration in Jewish-Roman relations. Josephus does not record any specific incidents from Albinus' time to substantiate his claims in the War, instead making only generalized slanderous allegations. In the Antiquities, however, Albinus' procuratorship takes its place after other corrupt governors and when conditions have already deteriorated substantially. There is therefore not the same need to place a great deal of blame on Albinus' character in particular and Josephus is content to relate only a couple of incidents involving the procurator. Finally Florus receives the same

\footnotetext{
1 Josephus correspondingly whitewashes the picture of the Jewish crowd during his time of office. In the first incident (20.105-112) he omits their stone-throwing and in the dispute between the Samaritans and Jews he neglects to mention the massacre of Samaritans by Jews recorded in War 2.235. This gives the impression that Cumanus' attacks were less provoked.
} 
condemnation in the Antiquities as in the War (20.252-257): Josephus remarks 'it was Florus who constrained us to take up war with the Romans' (20.257).

Pilate's term of office therefore plays a much more important role in the Antiquities than in the War. He is the first of a succession of Roman governors who, by disregarding the Jewish law, plunge the country into chaos and encourage the rise of brigands, so incurring God's wrath upon the nation. Although brigands are not directly linked with Pilate's governorship, he is the first of the governors to interfere directly with Jewish customs. His governorship in the Antiquities marks a turning point in the affairs of the province.

\section{Summary of Pilate in Antiquities}

The governorship of Pilate illustrates many apologetic aims of the Antiquities. Jewish religious devotion and endurance is stressed in the first two episodes; the part played by Roman troops in the deterioration of conditions leading to the revolt is emphasized in the aqueduct affair; and the generally negative picture of the Samaritans is sustained in Josephus' description of their uprising. The characterization of Pilate itself merges with an important apologetic interest of the Antiquities, the interest in personal history and the relationship between guilt and fate, particularly in relation to the Jewish law. Pilate is portrayed as setting himself up against that law. Despite his generally competent handling of different situations throughout his governorship it is this attitude which ultimately determines his fate and leads to his removal from the province.

\section{The Historical Events}

Despite his strong personal and nationalistic interests, Josephus aimed at historical accuracy throughout his narratives. In Antiq 20.157 he claims that his target is the truth, in War 1.3 he claims to be narrating 'the facts' and in $\$ 16$ to 'hold historical truth in honour' 1 . Modern archaeology has confirmed the veracity of many of Josephus' descriptions of places and buildings whilst research into his use of sources suggests that he adhered closely to their substance and main contents ${ }^{2}$. As long as Josephus' theological and

\footnotetext{
${ }^{1}$ See also War 7.455

${ }^{2}$ For a survey of modem research into Josephus' value as a historian see especially Bilde, Flavius, pp 191-200. Which sources were at Josephus' disposal for his description of Pilate's
} 
apologetic tendencies are borne in mind, it should be possible therefore to reconstruct something of the historical events behind his narrative.

\section{1) The Standards}

Date

Due to its position at the beginning of the account of Pilate's administration in both War and Antiquities, the prefect's introduction of troops with iconic standards into Jerusalem is generally assumed to have occurred early on in his term of office ${ }^{1}$. Although there is no direct evidence linking it to Pilate's first year, ie AD 26, his behaviour does give the impression of a new governor testing public opinion and probably happened in the first winter of his term as Judaean governor.

\section{Pilate's Actions}

Josephus describes the objects of offence in differing ways in the two books. In War 2.169 Pilate introduces 'effigies of Caesar (Eikóvas) which are

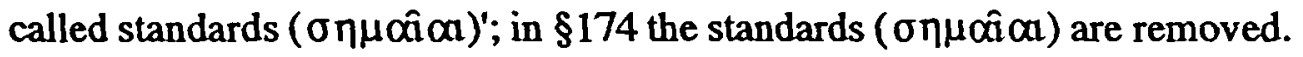

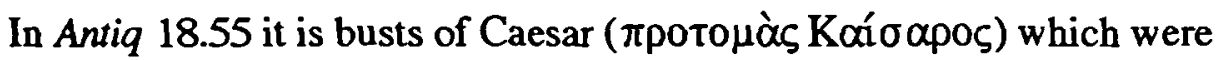
attached to the standards ( $\sigma \eta \mu \alpha \hat{\imath} \alpha 1$ ) which cause offence; in $\S 57$ the people ask Pilate to remove the images (Eikóvas) and in $\$ 59$ it is the images (Eikóvaৎ) which are removed. Despite the differences in terminology, Kraeling, in his important article on the subject, identifies these as iconic signa belonging to an infantry cohort ${ }^{2}$.

A squadron's standards were both sacred and necessary; they identified the unit and expressed its allegiance to the state and its religion. It would have been unthinkable for a governor to bring in a detachment without its standards

\footnotetext{
administration is uncertain. The War appears to be based only on personal recollection at this point (see War 1.18, the narrative of Nicolas of Damascus upon which the lengthy description of Herod I is based appears to end with the accession of Archelaus in 2.111, Thackeray, Jewish, vol ii, p 364, n a). In the Antiq Josephus (and his assistants) rely on a great many more sources, ranging from scripture to official edicts and lists of High Priests. Winter suggests that details of what occurred in Judaea under Pilate were derived from a written source, 'some sort of chronology composed by a contemporary of Pilate', Trial, p 74, n . 7.

Yet such a written source is not necessary, Josephus would presumably have been able to find out more details conceming Pilate's governorship in oral form from his family and older contemporaries in Judaea. For a survey of modem investigations displaying Josephus' careful use of his sources see Bilde, pp 98-99.

${ }^{1}$ Kraeling, 'Episode', pp 282-283, dates it to AD 26 as does Feldman, Antiquities, vol ix p 42 n. e, and Smallwood, Jews, p 161.

${ }^{2}$ Kraeling, 'Episode', pp 269-273.
} 
or to dictate what adornments these should bear ${ }^{1}$. Pilate must therefore have introduced an entirely new cohort into Jerusalem either to supplement, or to replace, the existing force in the city. This new cohort, perhaps as a sign of honour, had standards which contained images of the emperor and had not previously been deployed in Jerusalem by Pilate's predecessors (Antiq 18.56). The Jewish request that the standards be removed was synonymous with a request for the removal of the whole unit.

A more difficult question is Why did Pilate introduce these particular troops? Josephus' answer in the Antiquities, of course, is that Pilate deliberately acted to subvert Jewish customs. Yet the War gives no indication of this intention and it would be difficult to imagine a provincial governor, however harsh, deliberately initiating his administration with such a provocative move, one which, in the inevitable public discontent, could only jeopardize his own position. Brandon suggests that such a departure from the practice of previous governors could only have come from those who appointed Pilate; yet if this were the case it is surprising that he was apparently able to issue orders to withdraw the troops without prior consultation with his authorities ${ }^{2}$. An important consideration in interpreting Pilate's actions here is that Josephus, writing as a Jew, lays particular emphasis on the images whilst Pilate, as a Roman prefect, was in all probability interested only in troops. The governor's decision to alter the garrison would have been determined by practical military considerations ${ }^{3}$. The decision to send in one particular unit could quite easily have been made before the new governor realized, or it was pointed out to him, that this particular squadron could not be used in Jerusalem because its standards were offensive to the people. It might have appeared absurdly oversensitive to the Roman prefect that standards which were perfectly acceptable in Caesarea were not tolerated in Jerusalem and that certain standards would be allowed whilst others would not. Irritation that such religious scruples hindered his free deployment of troops may have led to Pilate's determination that the Jerusalemites would have to accept whatever troops he, as their prefect, decided to use. There may also have been an element of bringing Judaea into

\footnotetext{
${ }^{1}$ On standards belonging to auxiliary troops see Kraeling, 'Episode'; Spiedel, 'Roman Army", pp 224-232; Cheeseman, Aurilia , pp 39ff; Watson, Roman Soldier, pp 129ff; Webster, Roman Imperial, pp 136-148; Maxfield, Military Decorations, pp 218-234.

${ }^{2}$ Brandon, Jesus, p 69. The six days at Caesarea (during the winter according to Antiq) would not have been long enough to contact either the emperor or the Syrian legate. Brandon raises Sejanus as a possibility for the instruction but admits that it is impossible to identify the ultimate source of responsibility.

${ }^{3}$ Kraeling , Episode', p 295.
} 
line with other provinces, none of which dictated to the governor on military matters or refused to accept imperial portraits ${ }^{1}$. Pilate therefore placed his free use of troops above considering the religious sensitivities of his people. He probably thought that the expedient of bringing the troops in under cover of night would be enough to avert demonstrations: the people, faced with the garrison and its offending standards already installed, would have to accept matters ${ }^{2}$. Offending against the Jewish law was therefore not Pilate's prime intention ${ }^{3}$, though his actions do show arrogance and contempt towards the people and their customs, linked with an underestimation of the strength of their religious feeling. Anxious to take no nonsense from the people, Pilate's actions seem designed to establish from the start both his own superior position in the province and that of the empire which he served.

\section{The Jewish objection}

This demonstration of the superiority of Rome may shed some light on the Jewish objection. Ostensibly, of course, Josephus has taken pains in both accounts to explain this: the people were concerned only with the presence of images in Jerusalem contrary to their law, once these had been removed they were quite content ${ }^{4}$. Yet in all probability this represents only half the story. All Roman standards, whether iconic or not, were objects of worship and sacred to the unit which they represented ${ }^{5}$. This cultic importance could surely not have escaped the observance of the Jewish people, accustomed to

\footnotetext{
${ }^{1}$ See McGing, 'Pontius', p 434, who links Pilate's behaviour here with his minting of coins on which he changed existing policy by introducing types which were new to Judaea but wellknown in the rest of the empire. On his coins, however, Pilate showed a concern to combine both Roman and Jewish symbols, one on each side. The introduction of iconic standards shows no attempt to compromise with Jewish feelings. The coins date from after this incident (28-31) and perhaps reflect lessons learnt from the encounter. The Jewish people would not object to Roman aniconic symbols as long as they did not feel that their own religious/national identity was being compromised.

2The fact that Pilate was in Caesarea at the time of the change of troops and did not come to Jerusalem illustrates both that he did not want to draw undue public attention to the change of guard and also that he probably did not expect a great deal of public unrest.

${ }^{3}$ As Smallwood notes, there is no hint, even in Antiq, that Pilate deliberately tried to introduce emperor worship into the city, Jews, p 161.

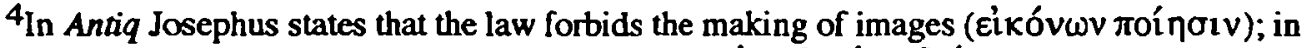

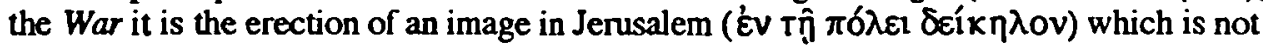
allowed.

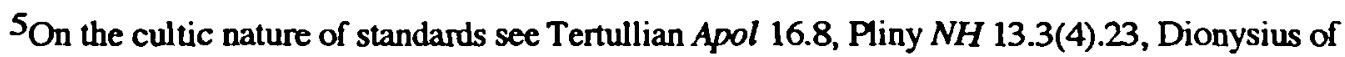
Halicarnassus 6.45.2, Tacitus Ann 1.39.7, 2.17.2. In War 6.316 Roman troops sacrifice to their standards after the capture of Jerusalem. Josephus is our only source for such a practice; its purpose was presumably to demonstrate the supremacy of the gods of the cohort over Yahweh as was the case with the setting up of standards on the walls at Jerusalem, 6.403. For a fuller discussion on standards see Kraeling, 'Episode', pp 275-276.
} 
the presence of Roman troops in their land for several decades ${ }^{1}$. The permanent garrison housed in the Antonia fortress in Jerusalem would therefore have been religiously offensive due to the worship of the standards and also politically and nationalistically offensive in that they were a permanent reminder of Israel's subjugation to a foreign power. This was probably always the case, ever since the days of Coponius. In general, however, the people were powerless to alter the situation: to demand the removal of the standards, and with them the troops, would at best have had no effect on the Romans for whom the Jerusalem garrison was vital in the effective policing of the nation, especially during festivals, and could at worst be construed as resisting Roman policy in the province. Previously then the people had no alternative but to accept the Roman garrison. But with Pilate's introduction of iconic standards the situation changed in the Jews' favour. Now they had a specific grievance to bring against the troops in the Antonia: their standards contravened the Jewish law banning images, a law which had been respected by previous Roman governors. In practice, as we have seen elsewhere, first-century Judaism tended to be selective and flexible regarding what offended against the second commandment ${ }^{2}$. The extreme anti-iconic tendency within Judaism to which Josephus' writings attest may be a reflection of resurgent nationalism in the early days of the revolt and not a dominant feature of conditions forty years previously. But iconic standards positioned in close proximity to the temple and used in pagan cultic worship would undoubtedly have been religiously offensive to many ${ }^{3}$. The people would also have been united by the threat that previously safeguarded rights were being

\footnotetext{
${ }^{1}$ Kraeling, 'Episode', p 281, and Smallwood, Jews, p 161, suggest that it was the iconic standards which made the people realise that all such signa were objects of worship. However, it seems incredible that the nature and significance of these standards were unknown to people familiar with experiences and stories of Roman military expeditions for almost a century.

${ }^{2}$ See the chapter on Philo and my article on Pilate's coins ( $\mathrm{p} 40, \mathrm{n} 5$ above). Roth, 'Ordinance', argues that there is no contemporary evidence for the pre-war period to suggest that there was a complete and effective ban on non-human effigies for decorative purposes (pP 170-171). Gutmann too argues that a rigidly and uniformly anti-iconic attitude throughout Biblical and Hellenistic-Roman times 'remains a myth', 'Second Commandment', p 174.

${ }^{3}$ As a contravention of the laws of Ex 20.4 and Dt 5.8. For a fuller discussion of Jewish attitudes towards the second commandment in the first century see the articles cited above, $n$. 83; Goodenough, Jewish Symbols, vols I - XIII; Lémonon, Pilate, p 151f. The fact that later tradition magnified the event into an attack on the Temple underlines the sense of violation which the people must have felt at the outrageous introduction of the standards. See in particular Eusebius Chron Tib 19, DE. 8.2, 122-123, Origen In Matt 17.25, Jerome In Matt 24.15. Also Megillat Taanit may refer to this incident when it records that on $3 \mathrm{Kislev}$ (Nov/Dec) 'the images were removed from the temple court'. See Smallwood, Jews, pp 161 162, n. 62; Zeitlin, Megillat Taanit, pp 239, 244, 259-261.

Sanders sees an attitude throughout Judaism from Hasmonaean times to Bar Kochba expressing willingness to die rather than transgress ancestral law, eg Test of Moses 9.6, Philo Hypothetica 6.9 (Judaism, p 284).
} 
infringed by a new Roman governor: not only were the hated pagan troops and their standards still in the Antonia fortress, but now their cultic objects contained images of the emperor. The toleration extended to their law could be used by the people as a front for demands which, though certainly with an important religious dimension, also had a nationalistic element. The appeal to the law was therefore, at least to some extent, a cover for a more political demand regarding the removal of the troops. Writing an apology for Judaism to subjects of the empire, Josephus has naturally enough covered up the political aspect of the affair ${ }^{1}$. In exactly the same way he stressed the religious side of the destruction of Herod's eagle above the temple, an action which undoubtedly showed a surge of patriotism and aggression against Roman overlords ${ }^{2}$.

\section{Events at Caesarea}

Josephus' presentation of the Jewish demonstration is obviously heavily coloured by his apologetic aims. McLaren is doubtlessly correct in assuming that the protest was not as spontaneous as Josephus relates; certain individuals would have been involved in its organization and the crowd would have aired their grievances through spokesmen ${ }^{3}$. Possibly the chief priests and aristocracy were involved. Nor was it in all probability as completely passive as Josephus would have us believe (as Pilate's use of the word Oopußaiv in fact betrays), though there is no reason to see a resort to arms. The people seem to have engaged in a relatively quiet protest in Caesarea, putting their case before the governor for six days.

Quite how far Pilate was aware of the various motives making up the Jewish demand is difficult to judge. Possibly he was aware of the political and nationalistic elements in the request. This might underlie his protest (recorded only in Antiq 18.57) that the removal of the standards would be an act of dishonour or outrage to the emperor. For a Roman military commander to allow his subjects to dictate which troops he could station in the province's ancient capital would indeed be an insult to the imperium invested in him by

\footnotetext{
'See Gutmann, 'Second Commandment', p 170 who cites Against Apion 2.6.

2 War 1.648-55, Antiq 17.151, 158-159. Josephus puts the blame on two rabbis, religious zealots who incited their pupils to remove the eagle which contravened the second commandment. However Josephus has not succeeded in eradicating all elements of what was probably an anti-Roman demonstration: he admits that the king's officer suspected 'that something more senous was involved' and came upon the crowd with a large force (Antiq \$156, War \$652).

${ }^{3}$ McLaren, Power, p 84. McLaren however regards this incident as identical with that descnbed by Philo, Leg 299-305. The spokesmen would therefore have been the four Herodians. For further discussion on the similarities between the two accounts see the chapter on Phulo.
} 
the emperor. This sense of outrage would be heightened all the more when the dispute concerned images of the emperor himself and troops which had possibly gained the honour of imperial effigies by military distinction ${ }^{1}$. Yet a provincial governor would presumably be equally anxious not to inaugurate his governorship by a breach of a national law which was generally tolerated by Rome. The Jewish delegation had a strong case: they could appeal to their scriptures for support of the law prohibiting the worship of images. Pilate was in a difficult situation: was he to insist on his own right to deploy freely any military unit in the ancient capital, or was he to uphold Rome's policy of toleration regarding ethnic religions? The first major incident in the career of any new ruler serves as the basis for relations between the ruler and the people in the ensuing administration. Pilate began with a demonstration of disregard for the ancestral customs of the Jews and precedents set by previous govemors. Yet the people seem to have been equally anxious to show the new governor that they would not tolerate such action when it clearly offended against their law.

Josephus' accounts give the impression that Pilate stubbornly sat out the Jewish demonstration, waiting for the people to tire and disperse. But the time may have been spent more profitably: Jewish deputies may have explained their religious objections to the standards to the governor whilst he reviewed the situation and what the practical implications of removing the troops would be.

Eventually he seems to have decided on a test of public opinion, intimidating the people with his troops to see how far they were prepared to go in upholding their laws. Impressed by their determination not to allow the new governor to contravene their laws and, if the demonstration was anything like the scale Josephus describes, perhaps annoyed that the people were neglecting their work, Pilate ordered the removal of the unit from Jerusalem. The depth of Jewish religious and nationalistic feeling, which he had seriously underestimated, was brought home to him by their restrained protest. In this first clash with the people, Pilate probably realized that their determination matched his own. Yet he eventually puts law and order in the province above

\footnotetext{
${ }^{1}$ Later in his administration Pilate was faced with a similar problem concerning the gilded shields narrated by Philo. In that case too he protested that the removal of the shields would be an insult to the emperor. But there the people demanded the removal of shields which had been set up specifically in honour of Caesar; by removing the shields Pilate ran a very real risk of appearing to dishonour the emperor. It was therefore necessary in that case to involve the emperor in the decision to remove the shields, particularly in the dangerous political climate of the early AD 30s. In the case of the standards, however, it would be extremely unlikely that Pilate used troops whose standards contained images of the emperor in order to honour him: practical military questions would have been to the fore when picking the troops. It was therefore safe for Pilate to remove the troops without prior consultation with Tiberius.
} 
personal pride: he shows enough flexibility to rescind his orders and replace the troops ${ }^{1}$. Self-interested motives may also have played their part: it would not have looked good in Rome if one of Pilate's first acts as governor was to massacre unarmed people.

\section{2) The Aqueduct}

\section{Pilate's Crime}

The building of an aqueduct to provide Jerusalem and its temple with a constant water supply sounds like a perfectly commendable procedure. The relevant passages in the War and the Antiquities give the impression that it was not so much the aqueduct itself which caused offence but something connected with it. The Antiquities rather vaguely notes that the people 'did not acquiesce in the operations which this involved' (oi $\delta$ 'oủK ìyó $\pi \omega v$ toîs

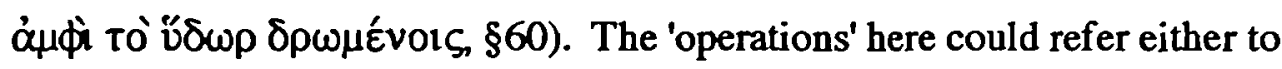
Pilate's use of the temple money or to the actual construction of the aqueduct. The War may throw some important light on this. Here Pilate not only 'spent' money from the treasury as in the Antiq but he 'used up' (' $\varepsilon \alpha v \alpha \lambda i$ í $\left.\xi^{\prime} \omega v\right)$ the money on an aqueduct of 400 furlongs $^{2}$; the people were 'indignant at this

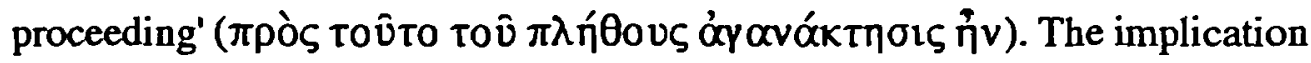
of the War is that it was not the construction of the aqueduct which caused offence but Pilate's misuse of temple funds, the fact that he had 'used up' or completely drained the available resources. These funds, known as Corbonas, were primarily used for sacrificial purposes ${ }^{3}$.

How did Pilate obtain money from the temple treasury? If he had simply taken it by aggression Josephus' account would doubtlessly have been written in a completely different way, expressing his horror that a pagan governor had violated the temple. In this case Pilate must have had the cooperation (whether voluntary or forced) of the temple authorities whose duty it was to administer the treasury 4 . According to Schuirer, although the

\footnotetext{
${ }^{1}$ McLaren, Power, p 83, also sees Pilate's actions here as a sign of flexibility rather than weakness. McGing sees it as a sign of 'weakness, a willingness to give in' p 429.

${ }^{2}$ In the Antiq the distance is given as 200 furlongs. For two possible archaeological remains of Pilate's aqueduct see Lémonon, Pilate, pp 168-170.

${ }^{3}$ For the composition of the temple treasury, which included gold, silver, materials, priests' garments and huge sums of money, see Schurer, History, vol II (rev), pp 279-284.

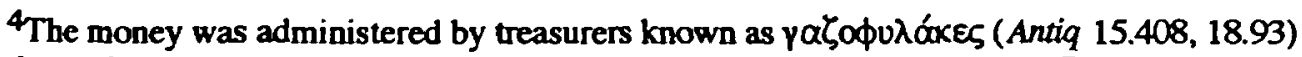
drawn from amongst the priests, see Schurer (rev) vol II p 281, Lemonon, Pilate, p 167. Lémonon also thinks Pilate worked alongside the priests, p 168, as does McGing, 'Pontius', p 429. The treasury consisted of the half-shekel annual tax payable by every male Jew over 20 (Ex 30:14-15), not only from Palestine but all over the empire (Antiq 14.215, 16.163, Leg 156), and also gifts. See Lémonon p 165 for further details.
} 
administration of the treasury lay essentially in the hands of the priests, during Roman rule there was a certain amount of political supervision by the governor ${ }^{1}$. Some explanation may be thrown on the proceedings by $\mathrm{m}$.Shek 4.2 which allows the use of surplus money from the treasury to be used for 'all the city's needs'. The dating of this ruling is uncertain but it is possible that it, or a similar earlier ruling, was in force in the first century. If this was the case then Pilate's use of the surplus for improving the city's water supply would presumably have been permitted. The temple treasurers would therefore have handed over the surplus from their funds to pay for the aqueduct. Whilst the War's use of the verb $\dot{\xi} \xi \alpha v \alpha \lambda i ́ \sigma k \omega$ may be over-exaggerated, problems seem to have arisen when Pilate began to demand more than the surplus for his venture. Building projects are notorious for requiring more money than initially expected; perhaps the aqueduct too began to require more and more funds which Pilate continued to demand from the temple treasurers, eventually using up more than the allowable surplus and draining the supplies for the daily sacrifices. Possibly too Pilate began to take his use of the money for granted, demanding and expecting that the priests would hand it over to him and treating it as his own fiscus rather than sacred money from the holy temple ${ }^{2}$.

\section{The Jewish Objection}

One noticeable feature of this incident is that the Jewish objection does not appear to have been spontaneous. The people wait for Pilate to visit Jerusalem before voicing their grievances. The aqueduct appears to have been already underway, if not already completed, when the riot breaks out. The occasion of Pilate's visit may have been a feast or even the opening of the aqueduct. The nature of the Jewish objection outlined by Josephus fits well with Pilate's conjectured 'crime' outlined above. Resentment at the prefect's use of the temple funds took some time to brew. Some may have never been happy about the arrangement from the start, unwilling to see sacred money being handed over to a pagan governor, whilst others may have accepted the

\footnotetext{
${ }^{1}$ Schürer, History, vol Il (rev), p283f. In Antiq 20.15 besides the right to name High Priests, Herod of Chalcis received authority over the temple and the holy vessels; Schurer suggests this authority previously lay with the Roman governors. 'As in the administration of the treasury, so in the completion of the temple buildings the priestly and political powers worked together' p 284.

2This is suggested by Lémonon who also thinks that the fact that the High Priestly vestments were in Roman control also added to the hostility. The Roman govemor would appear to be not content with controlling the use of the vestments but also treating the temple treasury as his own private funds. He also suggests that Pilate's initiation of the affair may have also caused offence and that his decision would have left the priests with very little chance to object, Pilate, p 168.
} 
arrangement initially but as Pilate demanded more than simply the surplus they became disillusioned and angry. Some may have been ready to jump at any chance to engage in anti-Roman riots; others may have favoured the arrangement, thinking that it was better to use surplus temple money rather than be required to pay a new tax for the undertaking 1. Gradually, however, many of the people may have become irritated at what appeared to be Pilate's continual use, even control, of their treasury. If his use of the money went so far as to requisition money reserved for the sacrifices then this too would have been a serious ground for complaint.

How complete was the Jewish resentment and hostility towards Pilate's undertaking? The War gives the impression that the whole populace joined forces to surround Pilate and make their grievances known. The Antiq, however, gives the impression that not all were involved in the riot; only some hurled insults and abuse, and in $\$ 62$ there is a reference to those who were not rioting. Yet both these accounts may have been influenced by Josephus' particular apologetic aims: the War illustrating the negative effects when the whole people turn to rioting; the Antiquities exonerating some of the people and stressing that they were unarmed in an attempt to glorify the nation. Neither statement can therefore be taken at face value. But two other factors suggest that the account in the Antiquities may be a more accurate reflection of the historical situation and that in fact not everyone was rioting. The first matter for consideration is the nature of the 'crime' itself. It would be readily understandable if the people were divided over the extent to which they saw Pilate's behaviour as an infringement of their law or native rights. The same division of the community appears to have occurred later in the differing attitudes towards the shields set up by Pilate in his residence in Jerusalem ${ }^{2}$. Secondly, Pilate's methods of dealing with the problem (2.176). If the prefect had been met with large-scale rioting the obvious course of action would be to bring in his troops and intimidate the people into submission. Sending in 'plain-clothes men' into such a situation could have been disastrous: once a soldier had exposed which side he was on by clubbing a rioter, he would be open to attack from the surrounding Jews; on a large scale Pilate would be sending his men into a potentially highly dangerous situation armed only with clubs. It makes more sense to see a large crowd in which only a more extreme

\footnotetext{
${ }^{1}$ See chapter 1 for the common procedure throughout the provinces of levying taxes for roads or particular building projects.

${ }^{2}$ See the chapter on Philo.
} 
element were rioting. Here, Pilate's policing actions would make sense ${ }^{1}$. A large display of troops to intimidate the people would be out of place in such a scene. But disguised troops who could unobtrusively move through the crowd and deal with trouble-makers without causing undue panic would be perfect. Whilst a large crowd had gathered about the governor, therefore, not everyone was rioting 2 .

The 'plain-clothes men' with their clubs raise one more question: did Pilate expect trouble, knowing that he had caused offence by his use of treasury funds? Even if his use of the money was justified and relations with the temple authorities were initially perfectly cordial, he would probably become gradually aware that resentment at his excessive use of the fund was building up. Pilate may not have expected a mass protest but the men were necessary for the relatively small degree of hostility which the governor expected. Pilate here shows a reluctance to use an excessive amount of force though his methods led to a certain amount of panic.

This incident shows a certain degree of co-operation between Pilate and the Jewish religious authorities. The aqueduct should have been beneficial not only to the inhabitants of Jerusalem but also for the temple; possibly it was initially designed as a joint venture to promote good relations between the governor and the people. The increasing debts incurred by the project and perhaps an over-bearing, demanding manner from Pilate eventually led to opposition ${ }^{3}$. The precise date of this incident is unknown; according to Josephus' chronology it must have occurred between AD 26 and the death of Jesus (generally assumed to have been in either AD 30 or 33).

\section{3) The Execution of Jesus}

The Testimonium Flavianum adds little to our picture of the historical Pilate. The governor has only the messianic leader executed, not his followers; probably Pilate thought that by executing the ringleader the disturbance would die down. Again, this shows a dislike of excessive

\footnotetext{
${ }^{1}$ Brandon similarly sees Pilate's actions as having more in common with a police rather than a military operation, Jesus, p 76, $\mathrm{n} 3$.

${ }^{2}$ McLaren also sees a split in the reaction of various Jews to the building project though he bases his arguments on Antiq 18.62, Power, p 86.

${ }^{3}$ For another building project connected with Pilate see the description of his Tiberieum in Caesarea, chapter 1 .
} 
violence. As previously in the aqueduct incident, Pilate is shown working closely with the Jewish hierarchy ${ }^{1}$.

\section{4) The Samaritan Uprising and Pilate's Return to Rome}

\section{a) The Samaritan Uprising}

Before assessing Pilate's actions it is necessary to consider exactly what the Samaritan disturbance involved 2 . Central to Samaritan thought was the idea that Mount Gerizim was Israel's one true sanctuary3; it was the only place where sacrifice was acceptable and prayers and praise efficacious. Even after Hyrcanus destroyed the Samaritan temple the beliefs associated with the mountain continued. It was equated with Bethel, the gateway to heaven; many of the patriarchs were believed to have their tombs on or near the mountain. The Samaritan Chronicles assert that God hid the ark of the covenant and sacred cultic vessels in a cave on Mt Gerizim in a time of divine disfavour inaugurated by the wicked priest Eli4. Samaritan eschatology centred upon a figure known as the Taheb. His function was to act as a restorer or revealer of the truth; he was seen as the prophet like Moses of Dt 18:18, or sometimes Moses redivivus, in contrast to the Davidic messiah of Judaea 5 . This figure was expected to reveal the ark and the vessels on Gerizim in preparation for true worship on the mountain and the inauguration of a period of peace and prosperity for the Samaritan nation ${ }^{6}$. Josephus' description of Samaritan activities in Tirathana ${ }^{7}$ have obvious parallels with such expectations. The unnamed Samaritan seems to have posed as the expected Taheb and persuaded the people that he could reveal the ark and restore true worship to the mountain.

\footnotetext{
${ }^{1}$ A fuller historical discussion of this particular event will be reserved until after the gospel accounts.

${ }^{2}$ For Samaritan theology see especially MacDonald, Theology ; Montgomery, Samaritans; Haacker, 'Samaritan'; Bowman 'Early Samaritan', pp 63-72.

${ }^{3}$ This comprised the tenth Samaritan commandment. Although the mountain is only referred to twice in the Pentateuch, the Samaritans found scores of implicit references to it and its status as Israel's true cultic centre.

${ }^{4}$ This is also attested in the fourth century Samaritan work Memar Markah 77b. The belief is probably much older and in all likelihood lies behind the passage in Josephus; see Montgomery, Samaritans, p 239. A corresponding Jewish belief is to be found in 2Macc 2 . 5see Jn 4.25.

${ }^{6}$ The biblical warrant for this was found in Dt 27.2-3; MacDonald, Theology, $\mathrm{p} 330$.

${ }^{7}$ Montgomery locates this as modern Tire, $4 \mathrm{~m}$ S.W. of Shechem, Samaritans, p 146, n 15.
} 
Though bereft of a sanctuary, sacrifice continued on Gerizim in the first century, ministered by the Samaritan High Priest and priesthood. Each year the people climbed the mountain three times to celebrate the three great pilgrimage feasts: tabernacles, passover and weeks ${ }^{1}$. It is possible that the first century 'Taheb' appeared before one of these established feasts. Or, perhaps more probably, he may have appeared shortly before the Day of Atonement (10th Tishri), the most important Samaritan feast and the day on which the Taheb was to make a proper atonement for Israel and to establish the period of divine favour ${ }^{2}$. Although this new age was to be one of peace, the Samaritans may have expected opposition in their ascent of the mountain and so were armed ${ }^{3}$. Some texts envisage an eschatological war between the Taheb and Israel's enemies before the restoration of true worship. If such a view was current in the first century this would provide an additional, and more ominous, necessity for the arms.

But such a 'religious' movement would inevitably lead to repercussions on a political level. A Roman governor could not allow such a potentially dangerous movement to escalate. Pilate was therefore acting well within his rights as the protector of Roman law and order in the province by intervening in the situation. As McGing notes: 'a Roman governor who did not deal with the situation firmly would be failing seriously in his duty'4. Pilate's actions do not seem unnecessarily severe. According to Josephus he sent in 'a detachment of cavalry and heavy armed infantry'; they are not sent to the village but to block the path up the mountain ( $\$ 87)$. The aim was not to massacre the people but simply to stop their intended course of action. Nor does the military intervention appear particularly severe 5 . Certainly Josephus does not mention huge losses; his note that some were killed in a pitched battle whilst the others fled gives the impression that the majority were put to flight. Of the remaining prisoners Pilate put to death only the leaders and most influential people; here again he was well within his rights as provincial governor exercising the power to judge and to execute which fell to the prefect

\footnotetext{
${ }^{1}$ See Bowman ,'Pilgrimage', pp 17-28. Only every seven years were all the people expected to appear before God, generally only selected groups attended.

2See MacDonald, Theology, p 267; Bowman ,'Early Samaritan', p 63.

${ }^{3}$ MacDonald, Theology, p 363. Later, during the revolt (AD 67), large numbers of Samaritans again assembled on Mt Gerizim ready for a conflict with Rome, giving way only when the water supply ran out. This assembly may also have been messianically and nationalistically inspired.

${ }^{4}$ McGing, 'Pilate', p 433.

${ }^{5}$ There does not seem to be any justification for Lémonon's comment that the soldiers behaved as brutally here as in the aqueduct affair. Besides, the alleged brutality of the soldiers in the latter may owe more to Josephus' apologetic than to historical reality, Pilate, p 237.
} 
of the province. This incident must have occurred in AD 36, possibly just prior to the Day of Atonement celebrated in September, which would allow time for the delegation to Vitellius and Pilate's return to Rome shortly after March 37.

\section{b) Pilate's Departure}

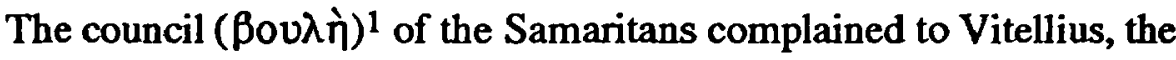
legate of Syria, about Pilate's handling of the Mt Gerizim affair. The legate would be the first, and most obvious, arbitrator when dissension arose between the governor of Judaea and the people ${ }^{2}$. The Samaritans allege that they assembled not as rebels against Rome but as refugees from Pilate's persecution. This supports the suggestion that they were about to embark on a messianic trek with the unnamed Samaritan as Moses at their head; the messianic aspect (and so the potential threat to Rome) has been carefully omitted.

Josephus gives the impression that Vitellius dispatched Marcellus and sent Pilate to Rome immediately. It is perhaps more likely that some exchange between Pilate and the legate occurred. Pilate would obviously have given his side of the story, how the uprising had appeared to threaten Roman stability in that part of the province and how he felt it was necessary to quell it, while the Samaritans were stressing the religious nature of their protest and charging Pilate with ruling unbearably harshly. Vitellius wisely decided to refer the case to the emperor: later Quadratus, faced with contradictory stories from Jews, Samaritans and Cumanus similarly decided to send the governor and representatives from the two nations to Claudius 3 . There is no indication that Vitellius thought that Pilate was to blame; he may have simply wanted both sides to have a hearing at the highest level so that no repercussions could ensue, especially when one of the issues at stake was the quality of rule by a Roman official. Vitellius was competent neither to dismiss Pilate nor to appoint his successor; Marcellus was acting as temporary governor until the case was over 4 .

What would have happened to Pilate if Tiberius' death had not intervened before his return to Rome is unknown: the Samaritans had

\footnotetext{
1 On the Samaritan council see Montgomery, Samaritans, pp 87-88.

2 On the relationship between the provinces of Syria and Judaea and the role of the Syrian legate in Judaean affairs see chapter 1.

3 Antiq 20.132, War 2.244.

${ }^{4}$ For the date of Pilate's retum to Rome see chapter 1.
} 
maintained good relations with the Romans ${ }^{1}$ and the emperor respected the religious traditions of ethnic groups. As Lémonon has argued, however, the fact that Gaius did not reappoint Pilate does not necessarily indicate an unfavourable outcome to his trial. After a governorship of ten years and with the accession of a new emperor it was the obvious time for Pilate to accept a new commission ${ }^{2}$.

\section{Conclusion}

In the Jewish War, Josephus presents us with a relatively able yet insensitive governor of the Roman Empire. Two incidents during his rule underscore the major apologetic argument of the whole work: a nation's peace and harmony depends upon quiet acceptance of Roman rule, not violent uprisings. Pilate is described in more detail in the Antiquities and in much harsher terms. Although he governs with a certain degree of competency, he sets himself against the Jewish law and is eventually sent back to Rome by Vitellius to answer for his crimes. Pilate, along with other Roman governors in this work, plays his part in the gradual decline of Jewish society into revolt.

The historical reconstructions of the events behind Josephus' stories, however, show a governor intent on inaugurating his government with a firm hand, reluctant to take any nonsense from the people he is to govern. Yet at the same time he can show flexibility and an ability to stand down in the interests of preserving peace. He seems to have been able to work alongside the priestly authorities with Caiaphas at the head and the aqueduct was to have been a joint venture, Jewish and Roman authorities working together to the benefit of the people of Jerusalem. Faced with potentially difficult political events, the earlier ones at a time when the protection afforded by the Syrian legate was missing, Pilate appears to fulfil his duty of effectively maintaining law and order in the province without recourse to undue aggression.

\footnotetext{
${ }^{1}$ They had not revolted after Herod I's death and were subsequently remitted a quarter of their tnbute (War 2.96, Antiq 17.319). The political value of Samaria was appreciated not only by Herod I but also by Rome: the district acted as a firm foothold in the province against the turbulence of the Jewish inhabitants; the pagans in the city of Sebaste despised the Jews whilst the Samaritans hated them. See Montgomery, Samaritans, p 82.

${ }^{2}$ Lémonon, Pilate, p 238; McGing also makes the same point, 'Pontius', p 434.
} 


\section{CHAPTER 4}

\section{Pilate in Mark's Gospel}

With Mark's gospel we move from Jewish literature to our earliest surviving reference to Pilate in a Christian gospel ${ }^{1}$. The work itself gives no specific date and there have been various attempts to fit the contents of the gospel to known historical events. At the earliest end of the spectrum a date shortly before Gaius' assassination has been suggested (AD 41) ${ }^{2}$ or, on the basis of possible Qumran fragments, just prior to $\mathrm{AD} 50^{3}$. The majority of scholars, however, date the gospel some time between AD 60 and 70; more specifically, opinion is divided between whether it was written shortly before or shortly after the fall of Jerusalem ${ }^{4}$. The place of composition is no less disputed with hypotheses ranging from Jerusalem ${ }^{5}$, Alexandria ${ }^{6}$, Antioch $^{7}$, Galilee $^{8}$ and Rome ${ }^{9}$, the last representing the majority view. Early church

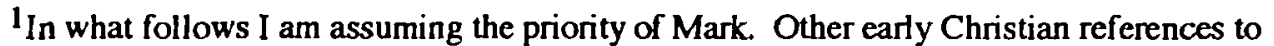
Pilate occur in Acts 3:13, 4:27, 13:28 (by allusion) and 1Tim 6:13. Curiously, Paul never mentions Pilate in any of his genuine letters, even in 1Cor 15:3 where a reference might have been expected.

2Torrey, taking 13:14 to be Gaius' statue; cited by Taylor, Gospel, p 31 .

${ }^{3} \mathrm{OC}^{\prime}$ allaghan, 'Papiros', pp 91-100; against this view see Benoit, 'Note', pp 321-324.

${ }^{4}$ Those who date it before AD 70 include Cranfield, Mark, p 3ff; Lane, Gospel, p 7ff; Taylor, Gospel, pp 26ff; Swete, Gospel, pp xxxixff; Schweizer, Good News, p 25; Nineham, Gospel, pp 38ff; Hengel, Studies, pp 1-30; Kee, Community, p 100f; Martin, Mark, pp 51-83; Bruce, 'Date'; Best, Mark, p 35; Gundry, Mark, pp 1041-1045.

Those dating it after AD 70 include Hooker, Gospel, pp 5ff; Brandon, Jesus, pp 221282; Kelber, Kingdom , p 1.

${ }^{5}$ Suggested by Wellhausen, cited by Rawlinson, Gospel, p xxx. This particular view has not won any wide acceptance.

${ }^{6}$ Chrysostom linked the gospel with Egypt, Hom in Matt 1, though this may be a mistaken inference from Eusebius $H E$ 2.16.

${ }^{7}$ This may be more probable than Alexandria but no ancient writers connect the gospel with Syria. The fact that Mark translates Aramaic words for his audience does not necessarily go against an Antiochean origin (so Best, Mark, p 35) since the majority of city dwellers would presumably have spoken Greek rather than Aramaic. The explanation that two $\lambda \varepsilon \pi t \grave{\alpha}$ make up a quadrans (12:42), however, would be meaningless in the Eastern provinces since the latter coin was only used in the West.

${ }^{8}$ This view is especially associated with Marxsen (Evangelist, pp 66ff) who suggested that the gospel was an exhortation to Jerusalem Christians to flee to Pella in the early stages of the siege of Jerusalem with the promise that the expected parousia would take place there. But apart from the fact that a gospel appears to be entirely the wrong literary form for such a straightforward and urgent message (and the facts that Pella is in Peraea and the author of the gospel of ten appears to be ignorant of Palestinian geography), the endurance of the gospel and references within the text to the continuance and growth of the Gentile Christian community suggest that it was not originally composed as a 'llysheet' for Jerusalem Christians promising an immanent parousia. A rejection of Marxsen's theory, howcver, does not necessarily mean a rejection of Galilee, see for example Kelber, Kingdom, pp 129ff; Myers, Binding, p 41; Kee
} 
tradition is virtually unanimous in its assertion that the gospel was written in Rome shortly after Peter and Paul perished in the Neronian persecution of AD 641. Since the contents of the gospel seem to support the traditional view of its provenance ${ }^{2}$, the following discussion assumes that Mark was writing for a predominantly Gentile Christian audience in Rome after the persecution of 64 but before the fall of Jerusalem. The picture of Pilate which emerges from this gospel appears to be particularly appropriate for a community which had recently suffered such misery and humiliation at imperial command.

Pontius Pilate appears twice in Mark's gospel. In 15:1-15 he directs the Roman proceedings against Jesus; later, in 15:43-45, he grants Jesus' corpse to Joseph of Arimathea. The text for the trial is as follows:

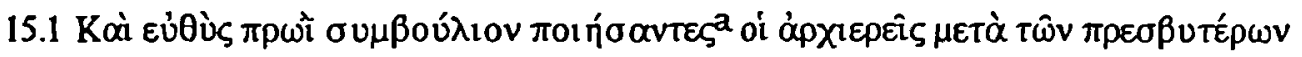

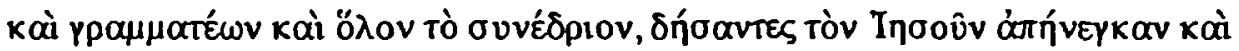

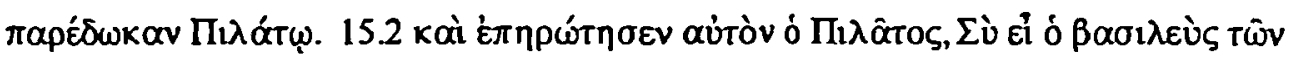

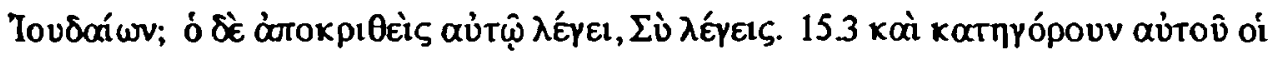

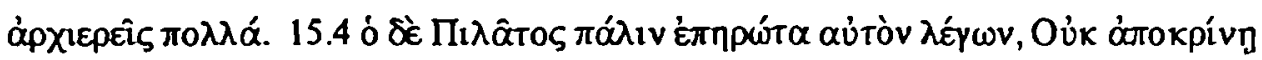

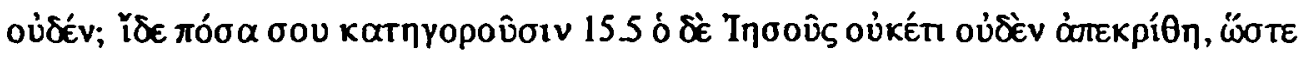

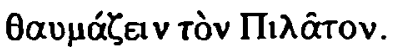

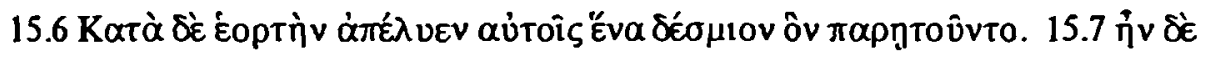

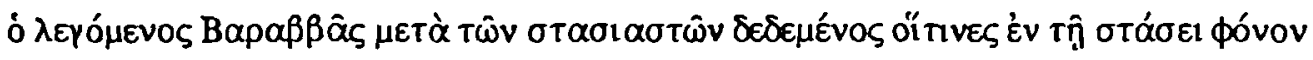

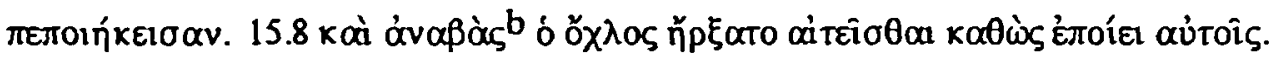

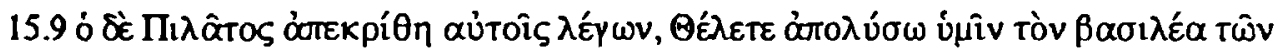

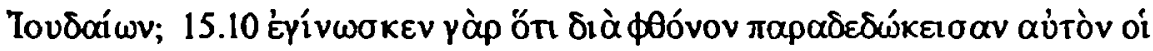

suggests Southern Syria, Community, p 101-103. However, these theories meet with the same three difficulties as Antioch (see n. 7). Other scholars think that Mark originated in a large city of the Roman Empire but do not specifically link it with Rome, for example Hooker, Gospel, pp 5ff; Anderson, Gospel, pp $25 \mathrm{ff}$.

9Those in favour of Rome include Cranfield, Lane, Taylor, Swete, Schweizer, Nineham, Rawlinson, Hengel, Brandon, Matera, Bruce, Best and Gundry.

${ }^{1}$ Irenaeus, Adv. Haer. 3.1.1, Anti-Marcionite Prologue and Papias, quoted in Eusebius H.E. 6.14.6 and 3.39.15, Clement of Alexandria, Hypotyposes 6. See Hengel, Studies, pp 2-6. Tradition also associates Mark's gospel with Peter and its author as the John Mark known to us from Acts 12:12. For varying analyses of these traditions compare Hengel with Niederwimmer, 'Johannes Markus', pp 172-188.

${ }^{2}$ See for example Hengel's analysis, Studies, pp 7-30.

a This reading, classed by a $\{B\}$ in UBS Greek NT ${ }^{3}$, can mean either 'to convene a council' or 'to take counsel, make a plan'; to resolve the confusion some authorities have $\sigma v \mu \beta 0 u ́ \lambda$ iov Étoı $\mu \alpha ́ \sigma \alpha v T \varepsilon \zeta$ (*, B, D, 892). See Metzger, Textual, p 117.

${ }^{b}$ This reading is also classed by $\mathrm{a}\{\mathrm{B}\}$ in UBS Greek NT ${ }^{4}$; the variant reads $\alpha$ ' $\alpha \beta$ ón $\sigma \alpha \alpha$, to cry out, but is not so well supported. Sce Metzger, Textual, p 117. 


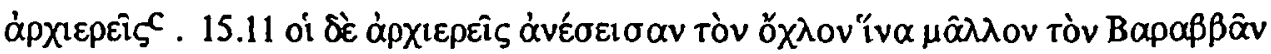

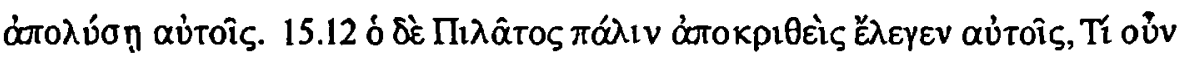

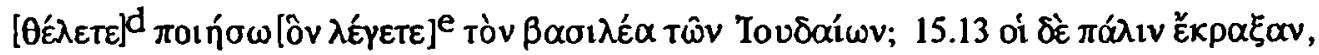

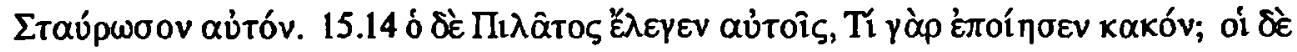

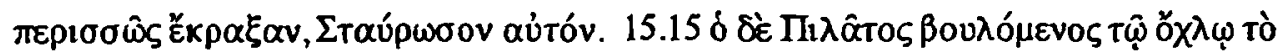

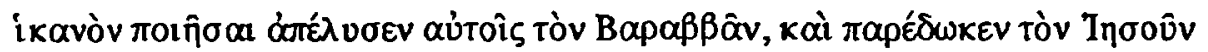

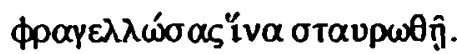

\section{Context}

Both references to Pilate in this gospel are to be found in what is generally referred to as Mark's passion narrative; that is, 14:1-16:8. Chapters 1-12 of Mark describe Jesus' teaching and ministry over a period of about one year; the narrative unfolds quickly as Jesus and his disciples move from one geographical location to another before finally embarking on the long trek to Jerusalem in 8:27-10:52; many short pericopae are joined to one another by

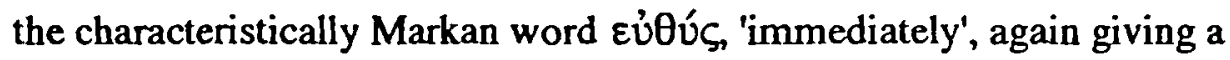
feeling of speed and intensity. Jesus' preaching and teaching culminate in Jerusalem where he delivers a long eschatological discourse to his disciples, warning them of tribulation to come and portents of the end (chapter 13). These chapters give the impression that events are speeding towards some goal; with chapters 14-16, however, that goal has been reached: the pace of the narrative is slowed down considerably; the rather vague $\varepsilon \dot{\theta} \theta \dot{v} \varsigma$ has given way to specific indications of time, every hour now becomes important ${ }^{1}$. This goal is the description of Jesus' death on the cross and subsequent resurrection. The threat of his impending death has loomed like a black shadow over Jesus' ministry since its earliest days but becomes prominent after events at Caesarea Philippi (9:2-13). Jesus himself has pointed to it, both by means of three explicit statements $(8: 31,9: 31,10: 33-34)$ and by references such as the absence of the bridegroom (2.20), the suffering of the Son of Man (9:12), giving up his life as a ransom for many (10:45) and the parable of the tenants in the vineyard (12:1-12). The narrator has also pointed to it through the

\footnotetext{
${ }^{C}$ Again classed by a $\{B\}$ in UBS Greek NT ${ }^{3}$; the omission of oi ápxlepeis in several witnesses is probably a stylistic improvement.

$\mathrm{d}_{\text {This reading was classed by a }\{C\} \text { in UBS Greek NT }}{ }^{4}$; the textual evidence is fairly evenly matched, see Metzger, Textual, pp 117-118.

e Classed by a $\{C\}$ in UBS Greek NT ${ }^{4}$; the weightier textual evidence points to the omission of ôv $\lambda$ Éyete but ML 27:22 seems to presuppose the phrase; Metzger, Textual, p 118.

${ }^{1}$ For example 14.1, 12, 17, 15:1, 25, 33-34, 42, 16.1-2.
} 
reference to 'Judas Iscariot, who betrayed him' (3:19) and the death of John the Baptist (6:17-29) ${ }^{1}$. The passion account has therefore not only been carefully prepared for in the preceding narrative but forms its climax. In the final three chapters the author of the gospel takes his time to describe in careful detail the events of the last two days of Jesus' earthly life and the events of the following Sunday morning.

\section{Mark's Passion Account}

The self-sufficiency and narrative continuity which distinguishes the passion story from the previous groups of generally rather isolated pericopae was noticed by the form critics of the early twentieth century 2 . They suggested that the passion story was the first of the traditions associated with Jesus to become a continuous narrative. This had several points to recommend it: the similarity of the passion accounts in both the Markan and the Johannine traditions suggested that the precise sequence of events had become established relatively early ${ }^{3}$; the fact that the speeches in Acts, which may reflect early preaching, are dominated by Jesus' death and resurrection similarly suggested that this would quickly be cast in narrative form ${ }^{4}$; most of Paul's references to the cross are found in formulaic passages, eg 1Cor 15:3ff; finally, meditation upon and questions raised by the paradox of a crucified Christ would have necessitated an early coherent passion account ${ }^{5}$. Although

\footnotetext{
${ }^{1}$ Lightfoot also sees chapter 13 as a parallel to the passion; for example vv.32-33 speak of the hour', in Gethsemane 'the hour' has come (14:41). 'The arrival of the hour, the Lord's Passion and the sufferings and endurance of His Church are linked indissolubly together', Gospel, p 55.

2In partucular M. Dibelius, Die Formgeschichte des Evangeliums (1919), (ET From Tradition to Gospel, 1935); K.L. Schmidt, Der Rahmen der Geschichte Jesus (1919); V. Taylor The Formation of the Gospel Tradition (1935), esp pp 4462.

${ }^{3}$ See Luhrmann, Markusevangelium, pp 227ff for a table of similarities. But, as Luihrmann points out, although the passion accounts in both Mark and John appear surprisingly similar when a brief list of topics is compiled, eg arrest (Mk 14:43-52, Jn 18:1-11), trial and betrayal of Peter (Mk 14:53-72, Jn 18:12-27), Pilate (Mk 15:1-20, Jn 18:28-19:16), crucifixion and death (Mk 15:21-41, Jn 19:17-37), burial (Mk 15:42-47, Jn 19:38-42), women at empty tomb (Mk 16:1-8, Jn 20:1-18), this disguises the fact that the traditions associated with each heading in the gospels are frequently completely different (as a comparison of the Markan Sanhedrin trial with that in John will show), p 228. Furthermore, several of the events could hardly have happened in any other order - the arrest had to come before the trial which had to come before the crucifixion, etc. It is also possible that John was aware of Mark's account, see for example Donahue 'Pre-Markan', p 9 .
}

${ }^{4} \mathrm{Eg}$ 2:22-36, 3:17-26, 4:8-12.

In 1Cor 1:23 Paul asserts that the cross was a stumbling block to the Jews and folly to the Gentiles. The events surrounding such a humiliating death would have quickly demanded interpretation which in itself would have required a knowledge of the events. 
they were willing to allow certain Markan additions ${ }^{1}$, the earlier form critics regarded Mk 14:1-16:8 as a continuous narrative held together by specific references to times and places and with largely independent existence before its incorporation into Mark ${ }^{2}$. Modifications of this view held by more recent upholders of a form-critical approach are mainly a question of degree: all are agreed that some primitive narrative lies behind the Markan passion story, the dispute centres around how similar this was to what we now have in Mark ${ }^{3}$. Modern approaches to the passion narrative, however, have tended to move away from the constraints of such an approach. Rather than attempting to reconstruct Mark's purpose and theology by trying to uncover a tradition which he has altered and into which he has made insertions, structuralist and literary analyses of the gospel have concentrated on the way the author of Mark orders and presents his material to the reader, and the recurrence of theological or apologetic themes in the work as a whole 4 . In terms of language and theology, the passion narrative is an integral part of the finished gospel ${ }^{5}$. This has led to a greater emphasis on Mark as a creative author, not

\footnotetext{
${ }^{1}$ For instance both Dibelius and Schmidt saw the anointing episode as an insertion into the account (Mk 14:3-9), also the priest's plot (14:1b-2), the treachery of Judas (14:10-11) and the reference to the betrayer (14:17-21).

${ }^{2}$ Bussmann went so far as to suggest that Paul's use of katò tàs ypałas (1Cor 15:3) refers to a well-known wntten account of Jesus' passion and death, Synoptische Studien iii, pp 180191. As Taylor points out, however, this could equally well be a vague OT allusion or a collection of testumonies from scripture, Fonnation, pp 48-50.
}

${ }^{3}$ Pesch, Markusevangelium, vol II pp 1-27 sees a virtually unchanged text going back to the very first years after the events. Nineham thınks that a continuous narrative, itself made out of isolated stories, came into being fairly early on and that Mark relied on this though he felt no hesitation in adding to it, St Mark, p 365. Knox divided the passion narrativc into two sources, a 'disciples source' and a 'twelve source'. His hypothesis was that Mark had both sources in front of him and simply conflated the two accounts into one, Sources, pp 115-147. Taylor sımilarly saw two sources, suggesting that it is possible to discern a non-Semitic summary narrative underlying the passion account (consisting of 14:1-2, 10-21, 26-31, 43-46, $53,55-64,15: 1,3-5,15,21-24,26,29-30,34-37,39,42-46,16: 1-8)$ whose 'unity, continuity and stark realism mark it as a primitive complex'. This Roman passion account, which in itself may be composite, was then expanded by Mark with the aid of various additions of a strongly Semutic character, Gospel, p 658. Bultmann argued that the passion account developed from simple kerygmatic statements such as are found in the speeches in Acts or cast in prophetic form in Mk 8:31, 9:31, 10:33r. This simple account was developed at vanous stages, partly by the addition of earlier stories and partly by the reforming of the exusting narrative. In particular, the whole narrative was worked over at some point by the addicion of OT moufs supplying prophetic proofs of God's will in the crucifixion. Exactly which features are pre-Markan cannot always be certain, but Mark was certainly not following an old source which he felt bound to copy exactly (History. pp 275-284). An exception to thus general view is $\mathrm{E}$ Linnemann who rejected a pre-Markan passion account, seeing Mark as a collector of independent reports, Studien. For a much fuller survey of form-critical approaches to Mark's passion narrative see Donahue, 'Pre-Markan', pp 1-16, in Kelber, Pacrion.

${ }^{4}$ See Donahue, 'Pre-Markan', pp 16-20; Kee, Community; Malbon, Narrative; Myers, Binding; van lersel, Reading; Belo, Materialist; Best, Mark.

SOn the bomogeneity of the Greek style of Mark sce Neirynck, Duality, p 37. 
slavishly reproducing earlier tradition but selecting events and presenting them in a particular way to his readers. Although it is certain that Mark was using earlier traditions, the following analysis will not attempt to find these in the case of the Roman trial. Instead, Pilate's role will be assessed in the context of the gospel as a whole; that is, the characterization and meaning taken on by the Roman prefect due to Mark's skilful arrangement and presentation of his material in order to highlight his own particular theological or apologetic themes.

\section{Apologetic Themes Culminating in Mark's Passion Narrative}

Before tuming to Mark's portrayal of Pilate it may be useful first to note some of the apologetic themes in the narrative which may have had some influence on the way in which the governor has been portrayed.

1) An important theme throughout the whole gospel is that of the antagonism of the Jewish leadership. As early as 3:2 the Pharisees were alert to any accusations which they might bring against Jesus; by 3:6 they have taken council with the Herodians to destroy him. After the cleansing of the temple the chief priests have become involved and, with the scribes, seek a way to eliminate Jesus on the grounds that he was too popular with the crowds (11:18). With Judas' offer to betray his master in chapter 14 , the plots of the chief priests become reality $(14: 1-2,10-11)$. Mark spares no effort in his denigration of these leaders: not only are they plotters and schemers but sinners (14:41), and their trial of Jesus nothing but a sham, a travesty of justice $(14: 53,55-65)$. The author emphasizes the irregularity of the proceedings: the 'chief priests and the whole council' meet with the specific intention of putting Jesus to death, there is clearly no chance of a 'fair trial'

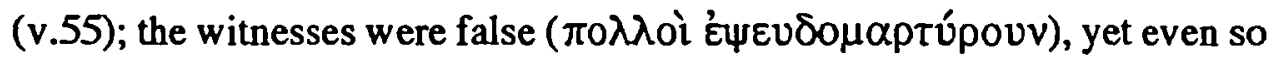
they were unable to agree (v.56-59); after Jesus has been condemned it is apparently members of the council who spit on him, cover his face, strike him and demand that he prophesy to them (v.65), hardly suitable behaviour for responsible members of a court. Throughout the trial Mark deliberately emphasizes the complicity of the whole council; in 14:53 Jesus is led to the High Priest, all the chief priests, elders and scribes are assembled; two verses later Mark stresses that it is the chief priests and the whole council who seek

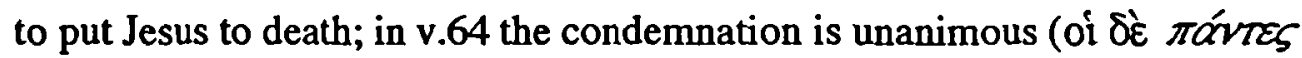

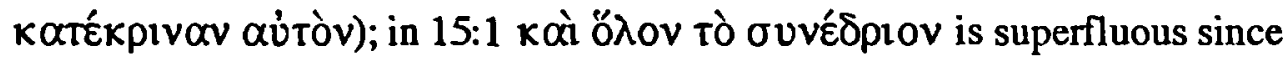
Mark has already listed the various groups which constituted such a 
Sanhedrin. This stress on the whole Sanhedrin underlines the guilt of every member of that council - the High Priest, chief priests, elders, and scribes 1 . All share the guilt of Jesus' death. In terms of literary genre, Nickelsburg has noted the similarities between the Markan passion account and Jewish court tales about the persecuted wise man who is rescued, vindicated and exalted to a high position, such as the Joseph narratives in Gen 37ff, and the accounts in Daniel or Esther, although of course none of these descend to the depths of degradation or achieve the exaltation accorded to Jesus by the Christian writers ${ }^{2}$.

2) An element which comes into particular prominence in the passion account is the frequent use of scriptural references or allusions. In particular the LXX of Is 53:12 appears to lie behind the Markan use of $\pi \alpha \rho \alpha \delta i \delta \omega \mu \mathrm{in}$ the passion predictions of 9:31, 10:33 and 14:21. Allusions to the suffering servant of Deutero-Isaiah are common, as are references to the psalms, eg Pss $34,41: 9,42: 6,11,43: 5,69: 21,109: 25$ and, especially in connection with the crucifixion, Ps $22: 1,7,18^{3}$.

The need for reflection upon Jesus' suffering and death was obvious: crucifixion was a shameful and humiliating death (Dt 21:22-23) ${ }^{4}$ and belief in a Messiah who was not only rejected by his own people but who was also crucified by the representative of a foreign power was 'a stumbling block to Jews and folly to Gentiles' (1Cor 1:23). The superficially disturbing events of Jesus' last days therefore needed to be interpreted in the light of scriptural references and shown to be in fact in accordance with God's will. Such Christian reflection would have begun at an early stage and it is unlikely that Mark was responsible for all the allusions. Probably he made use of existing scriptural 'proof texts', possibly he added others himself. What is important is that Mark retained them and incorporated them into his finished gospel. Together with Jesus' repeated predictions of his death, they show that all the events of Jesus' ministry, in particular his shameful death and resurrection, were in accordance with God's plan (9:12, 14:21, 49).

Scriptural motifs may be present in 15:1-5; in particular, these verses show several parallels with the suffering servant motif of Is 52:53. For

\footnotetext{
${ }^{1}$ Nineham, Gospel; all three are similarly named in 14:53.

${ }^{2}$ See Nickelsburg, 'Genre', pp 153-184. Nickelsburg suggests that Mark made use of an earlier account which similarly recounted the death and exaltation of Jesus using the genre of the story of the righteous one.

${ }^{3}$ See Lindars, Apologetic, pp $88 \mathrm{ff}$.

${ }^{4}$ See Hengel, Crucifixion.
} 


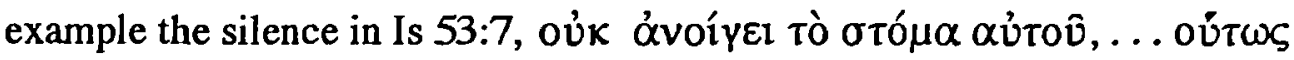
oủk óvoírel tò oró $\mu \alpha$ (also Ps 38:13, 14, 39:9, Od Sol 31:8, T. Ben 5:4);

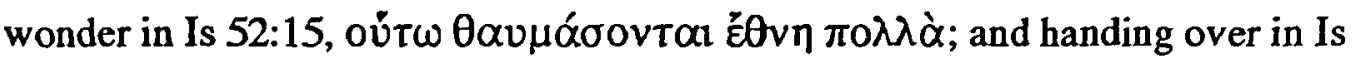

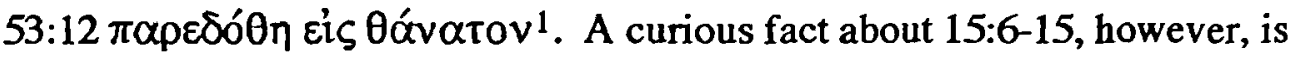
that, unlike the rest of the passion narrative, these verses show no discernible trace of scriptural references whatsoever ${ }^{2}$. This suggests that other themes were uppermost in Mark's presentation at this point.

3) An important theme of Mark's passion narrative and in particular his account of the Roman trial is kingship. Throughout 15:2-32 Jesus is referred to as the national king six times yet the title is never elsewhere used of him $^{3}$. The preceding chapters of the gospel have referred to Jesus as Christ (1:1, $8: 29,12: 35,14: 61)$, Holy One of God (1:24), Beloved Son $(1: 11,9: 7)$, Son of David (10:46ff, 12:35) or Son of God (3:11). Never before has anyone referred to Jesus as King, yet it is the charge against Jesus inscribed above the cross (15:26) and in chapter 15 Mark concentrates on this theme, defining in what sense Jesus really was the King of Israel. 15:1-15 highlight the Roman state's perception of messiahship in terms of a political King in opposition to Caesar, a perception which Mark has already shown to be false ${ }^{4}$.

4) Linked to kingship and forming its counterpart within the passion narrative is the theme of mockery. Jesus is subjected to a brutal, or at best undignified, mockery three times throughout the narrative: after his Jewish trial at the hands of the council members he is told to 'prophesy', spat upon and struck (14:65); after the Roman trial he receives an even more humiliating treatment at the hands of the Roman soldiers who mock him as 'King of the Jews' (15:16-20); even on the cross the passers-by, chief priests and his fellow

\footnotetext{
1 Van Iersel, Reading, p 191.

2Lohse, Mark's Witness, lists scriptural allusions in the passion narrative but has none at all for this section, p 78. Lindars similarly lists no references, cited by Donahue, 'Pre-Markan', p 4.

$315: 2,9,12,17,26$, and 32 . If Jesus' entry into Jerusalem is a re-enactment of Zech 9.9, then the theme of kingship, though not openly declared by the bystanders, is implicit here. See France, Divine, p 87. In 10:35ff the sons of Zebedee, two of Jesus' closest followers, still understand Jesus' kingdom as one in which the great will sit in places of honour.

4 Jesus' answer to the tribute question in 12:13-17 shows that his policy was one of quiet acquiescence towards his Roman overlords, political and divine authority need not necessarily conflict as long as God received his due; his answer would no doubt have seemed a deplorable compromise to those of Mark's readers with a more nationalistic outlook (see Paul's letter to Rome 13:1-7: had there been some dispute over the authority of pagan rulers a decade before Mark was written?). On these verses in Mark see Bruce, 'Render', pp 249-263, Dunn ,Caesar', pp 269-270. On the existence of a nationalistic or Zealot party in the time of Jesus compare Hengel, Zealots, with Horsley and Hanson, Bandits.
} 
prisoners mock him, taunting him to come down from the cross if he is the Christ, the King of Israel (15:29-32) ${ }^{1}$. This mockery in Mark is linked to a fundamental misunderstanding, both by Jews and Romans, regarding Jesus' messiahship ${ }^{2}$. Behind this mockery in Mark lies a bitter irony: the actors in the drama unconsciously speak the truth, a truth which exposes their lack of perception. Jesus' Jewish adversaries mockingly tell him to prophesy and, if he is the Christ, to come down from the cross. Yet the reader knows that Jesus is endowed with prophetic insight ${ }^{3}$; but he is more than a prophet, he really is the Christ, the King of Israel, even viós $\Theta \varepsilon o \hat{v}^{4}$; and far from coming down from the cross to save himself he remains there as a ransom for all people 5 . Jesus does not fit Jewish messianic specifications and so is rejected. Similarly the mockery at the hands of the soldiers centres upon the absurdity of the kingly claims of the scourged figure before them. To pagan troops the 'King of the Jews' would be none other than the emperor himself and it is as someone setting himself up against the kingship of Caesar that Jesus is ridiculed and abused ${ }^{6}$. Clearly such a worldly, political interpretation is at variance with Jesus' true identity, yet the soldiers unconsciously point to the truth. The mockery of Jesus' opponents, his own humiliation and Mark's irony, however, culminate in the title on the cross. Above the tortured body of a man dying of crucifixion Pilate affixes a titulus reading $O \beta \alpha \sigma \imath \lambda \varepsilon \dot{\zeta} \zeta \tau \hat{\omega} v$

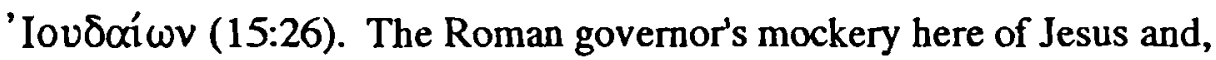
indirectly, the Jewish nation is self-evident ${ }^{7}$. It would not be surprising therefore to find an element of mockery within the proceedings before Pilate.

\footnotetext{
${ }^{1}$ Like the rest of the passion, this mockery was predicted by Jesus, 9:12, 10:34.

2 On the central role of irony and misunderstanding in the Markan passion narrative see Juel, Messiah, pp 47-52; Nickelsburg, 'Genre', p 172.

${ }^{3}$ For example the passion predictions 8:31, 9:31, 10:33-34; the eschatological predictions of chapter 13; and Jesus' knowledge of the colt (11:1-6) and the upper room (14:12-16).

${ }^{4}$ This is stated right from the very beginning, $1: 1$, and proclaimed by the divine voice in $1: 11$ and 9:7 and by the centurion in 15:39. On Christ see 8:27-30, 14:62. With the centurion's declaration in 15:39 and the titulus on the cross the two titles Son of God and Christ are once again brought together, the passion and crucifixion of Jesus having illustrated Jesus' identity first attested in $1: 1$.

$5_{10: 45,14: 24 .}$

${ }^{6}$ Purple was the colour of emperors, Rev 17:4, 18:16, Virgil, Georg II.495, Josephus, War 7. The crown of thoms does not seem to have been used as an instrument of torture but to mimic the radiate crowns worn by 'divine' Oriental and Hellenistic nulers as portrayed on their coins (Barrett, Gospel According to John, p 540; Brown, Gospel According to John, p 875), or the imperial wreath. Xoipe mimics the Ave Caesar used to address the emperor. In the Greekspeaking world the emperor was often referred to as $\beta \alpha \sigma \nu \lambda \varepsilon u ́ c$, see Barrett, p 543, Brown, p 880. In Acts 17:7 Jason and some others are accused of 'acting against the decrees of Caesar, saying that there is another King, Jesus'; in Jn 19:15 the chief priests acknowledge that their only king is Caesar.

${ }^{7}$ Mark does not specifically state here that Pilate was responsible for the title (cf Jn 19:19), but his readers would surely assume that it was he who communicated the official charge to
} 
5) A fifth Markan theme which has relevance for the trial before Pilate is that of rejection. One of the deepest tragedies of Mark's gospel is that Jesus is abandoned not only by the Jewish leadership but even by his closest followers in his hour of need and goes to his death almost completely alone. In 14:27 this isolation was predicted by Jesus: 'You will all fall away; for it is written, "I will strike the shepherd, and the sheep will be scattered"'. In v.50 of the same chapter the disciples have all fled after Jesus' arrest; in v.51-52 the young man runs away naked rather than stand by Jesus. Peter denies his master in 14:66-72, ironically at the same time as Jesus admits his true identity before the council ${ }^{1}$, and even those who were crucified with him in 15:32 revile him. In 15:34 even God forsakes Jesus. The only people who do not desert him are women, both from Galilee and Jerusalem, who watch the crucifixion from a distance (15:40-41) and, later, Joseph of Arimathea who courageously asks Pilate for permission to bury the body (15:42-46). In Mark's description of the Roman trial it is the once openly friendly crowd who forsake Jesus, abandoning him completely and demanding his execution.

This rejection ties in with another important Markan theme. Israel has not received its saviour and so Jesus' death entails the rejection of Israel and the extension of the gospel to encompass all nations ${ }^{2}$.

It is with these themes of Jewish antagonism, the importance of redefining kingship, mockery and rejection in mind that we need to turn now to considering Mark's portrait of Pilate within his passion account.

\section{The Characterization of Pilate in Mark}

The majority of scholars regard Pilate as a weakling in Mark's gospel, convinced of Jesus' innocence, vainly engaging in successive attempts to

the executioners. Unlike John's gospel, where the chief priests sense the mockery directed towards their own nation and ask Pilate to alter the title (Jn 19:21), the inscription in Mark seems to incite the chief priests and bystanders to further mockery in an attempt to disown Jesus completely. The evangelist, in common with the other three, makes little of Jesus' physical sufferings, the scourging and crucifixion are referred to only briefly with no details attached $(15: 15,24)$. This was perhaps out of a desire not to dwell on such painful and

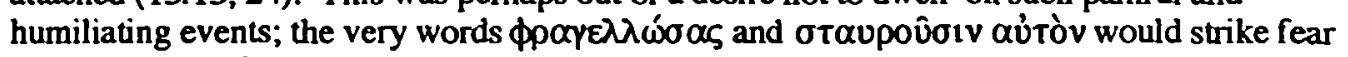
into the hearts of Mark's readers.

${ }^{1}$ The dove-tailing of the two stories in chapter 14:53-72 indicates that they occur simultaneously.

2Illustrated by the story of the withered fig tree after the cleansing of the temple; the tenants in the vineyard; and the rending of the veil of the temple directly before the centurion's confession in 15:39; Best, Mark, p 70f. 
release him but forced to go along with the wishes of the chief priests and the crowd ${ }^{1}$. Brandon remarks that Pilate 'acted as a veritable weakling, devoid alike of dignity, efficiency and spirit ${ }^{2}$. Nineham sums up the views of many when he asserts: 'most commentators think we should allow for some idealization in St Mark's account, arising out of the Christian desire to exculpate the Romans and put responsibility on the Jews ${ }^{3}$. Alternatively he is seen as not taking the case seriously, wishing to release Jesus if only to spite his Jewish antagonists ${ }^{4}$. Yet there are several indications within Mark's portrayal of the Roman trial which indicate that, read in a first-century context, Pilate is not to be understood as a weak impotent figure but rather as an astute governor who handles a potentially difficult case with a certain amount of mockery but at the same time a great deal of political shrewdness. The representative of Rome in Mark's gospel is not exculpated but plays his part in the events leading to Jesus' execution.

\section{The Handing Over to Pilate}

In Mark's portrayal, the hearing before Pilate takes place after a formal trial before a Jewish Sanhedrin (14:53, 55-65). Although the bias and injustice of the proceedings are stressed, Jesus clearly stands before a Jewish court facing a capital offence, a court which, however corrupt, did have the power to come to a legal decision. Witnesses are called, a unanimous verdict is reached and Jesus is condemned on a charge of blasphemy (v.64). It was presumably this decision which was reiterated the following moming at the consultation ( $\sigma \cup \mu \beta 0 v \lambda_{1}(\sigma)$ ) of the Sanhedrin $(15: 1)^{5}$. The three-fold naming of the parties not only stresses the guilt of all involved but also emphasizes the

\footnotetext{
${ }^{1}$ Eg Gnilka: 'Pilatus wird als Schwachling gezeichnet', Evangelium, p 305; Taylor. 'Mark gives a ... objective account, not hiding the weakness of Pilate, but showing plainly that he did not believe the accusation of the priests to be valid', Gospel, p 579; Brandon, Trial, regards him as a 'weak, abject figure' p 190, n .100; Best asserts that the trial before Pilate underlines the hostility of the Jews in that it shows Pilate making some attempt to save him, Temptation, p 96; Cole writes, 'for he stands self-revealed as he attempts in vain, first to avoid the issue, and then to escape responsibility for the decision', Mark, p 232; Van Iersel asserts that Pilate 'is persuaded against his will to approve and confirm the punishment'. See also Benoit, Passion, p 137; Nicklesburg, 'Genre', p 165; Gould, St Mark, pp 285ff; Pesch, Markusevangelium, p 459; Burkill, Mysterious, p 294.

2Brandon, Jesus, p 261.

${ }^{3}$ Nineham, Gospel, p 413.

${ }^{4} E_{g}$ Piper, 'God's', p 179; Lane suggests that Pilate's efforts to rescue Jesus were due to his 'anti-Semitic bias', though he gives no evidence to support this claim, Gospel, p 555;

5Bammel, Trial', p 415; Pesch, Markusevangelium, p 456.
} 


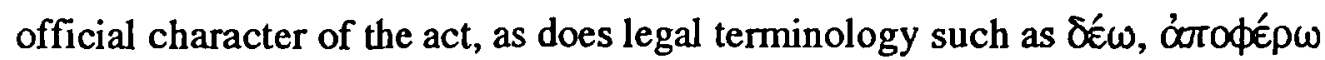
and $\pi \alpha \rho \alpha \delta i \delta \omega \mu \mathrm{l}^{1}$.

An important result of the morning meeting of the Sanhedrin is that Jesus is now 'bound' ( $\delta$ ŕ $\propto \alpha v \tau \varepsilon \zeta$ ). No such binding took place at Jesus' arrest, a fact perfectly in keeping with general procedure since the binding of a person only under accusation would have been unusual ${ }^{2}$. The fact that Mark describes Jesus being bound at 15:1, however, suggests that his legal status has now changed. The consultation of v.1a, which would have summed up the finding of the previous evening's inquiries, therefore, 'constituted an act that had its procedural consequences ${ }^{3}$. Jesus has been condemned to death, bound and is now handed over to Pilate as a culprit. The binding demonstrates to Pilate both Jesus' condemned state and his dangerousness. Mark's readers would know that native courts did not have the right of capital jurisdiction; any sentence of a Jewish court had to be retried, or at least ratified, by the Roman governor ${ }^{4}$. The construction $k \alpha \grave{~} \varepsilon \dot{v} \theta \dot{\zeta} \zeta \pi \rho \omega^{2}$ gives a feeling of speed to the proceedings; the Jewish authorities are anxious to have their death sentence ratified as soon as possible ${ }^{5}$.

Pilate is introduced abruptly in v.1 with no description of his official title; presumably his role in Jesus' death, and perhaps also something of his character, were sufficiently well known to Mark's audience to necessitate no further means of identification other than his name ${ }^{6}$.

\footnotetext{
${ }^{1}$ Noted by Pesch, Markusevangelium, $\mathrm{p} 456$.

${ }^{2}$ Mommsen, Römisches, p $391 \mathrm{ff}$. In John's gospel Jesus is bound immediately at his arrest and remains so throughout the night ( $\mathrm{Jn}$ 18:12,24).

${ }^{3}$ Bammel, Trial', p 415. Though commenting on the historicity of the Markan narrative at this point, Bammel's observations are still relevant for a literary understanding of the Markan text

${ }^{4}$ See chapter 1 .

${ }^{5}$ Though common throughout the rest of the gospel, the word $\varepsilon \dot{\theta} \theta u$ s is used only four times throughout the passion narrative. In all cases the word is associated with the immediate fulfilment of prophecy. In 14:41f Jesus tells the three disciples in Gethsemane that the hour

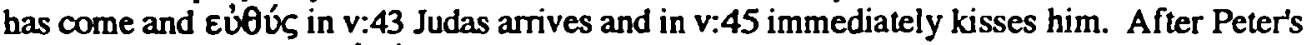
denial, the cock crows $\varepsilon \dot{\theta} \theta \dot{v} \varsigma$ (14:72), reminding the reader of Jesus' prediction in 14:30. In 15: 1 Jesus' general predictions regarding the passion are hurrying on towards their fulfilment. ${ }^{6}$ See Hengel, Studies, p 9. The omission of Pilate's title coupled with the fact that Caiaphas is never mentioned by name led Pesch to suggest the existence of a very old main source for the gospel which originated in or before the year AD 37 when both Pilate and Caiaphas were deposed, Markusevangelium, vol 1I, p 21. But this would be unnecessary since Pilate's name was very quickly associated with the crucifixion and would doubtlessly be known to Mark's readers.
} 
The charge before the Jewish court centred around Jesus' claim to be 'the Christ, the Son of the Blessed' (14:61); this was interpreted by the High Priest as blasphemy. Quite possibly this identification is anachronistic; Mark has retrojected contemporary disputes over the person of Jesus and associated Jewish charges of blasphemy, issues in church-synagogue disputes of his own day, back into Jesus' trial ${ }^{1}$. Pilate's question in 15:2 is not a new, political charge but goes back to the findings of the Jewish court, in particular to the

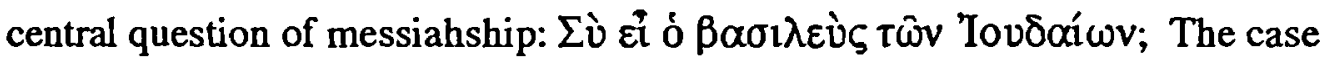
itself is not re-examined, only its political consequences ${ }^{2}$. The Roman governor is not interested in the religious meaning of messiahship but only in any political repercussions such a claim might have. His question therefore focuses on the political implications of the Jewish charge, in an attempt to gauge how far he might present a threat to Roman stability in the province ${ }^{3}$.

The actual title 'King of the Jews' is only used in Mark's gospel by Pilate and his soldiers $(15: 2,9,12,18,26)$; the phrase 'of the Jews' indicates that the speaker is not a Jew himself; when the Jewish chief priests mock Jesus on the cross they refer to him as 'King of Israel' (15:32) ${ }^{4}$. In a firstcentury Roman province the title would take on particularly dangerous connotations: anyone claiming any kind of kingship would run the risk of appearing to challenge the divine rule of Caesar 5 . Mark's readers would

\footnotetext{
${ }^{1}$ Burkill, Mysterious, p 289. The É $ү \omega \dot{\omega}$ Ei $\mu \mathrm{t}$ before the Jewish court (14:62) may be reminiscent of God's revelation before Moses (Ex 3:14) and the charge of blasphemy a reflectuon on contemporary Jewish-Christian debate concerning the divinity of Jesus. For fuller discussions of the Jewish charge see the relevant sections in Gundry, Mark, pp 891-922 or Brown, Death, pp 429-460, 627-635.

${ }^{2} \mathrm{Bammel}$, Trial', pp $417 \mathrm{fr}$. Mark's presentation is not so much a 'trial' as a hearing leading to the ratification of an existing condemnation.

3 Many commentators understand the $\sigma$ v in Pilate's question as contemptuous, indicating the governor's incredulity that messianic accusations have been levelled at such a prisoner, eg Pesch, Markusevangelium, p 457. But the ov may not necessarily be emphatic and so cannot be pushed as any indication of Pilate's surprise (Moulton, Grammar, III, p 37 doubts the emphatic nature of $\sigma v$ here). It parallels the $\sigma u ́$ in the question of the High Priest, 14:61.

4It is clear from 15:31-32 that King of the Jews = King of Israel = Messiah.

${ }^{5}$ As Jason and others found out by proclaiming Jesus' messiahship in Thessalonica, Acts 17:7. Their Jewish opponents charged them with 'acting against the decrees of Caesar, saying that there is another king, Jesus'. There is evidence that the later Hasmonaean rulers assumed the

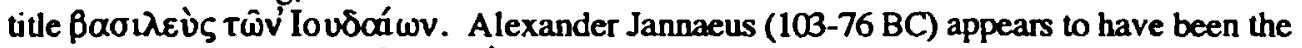
first to refer to himself as $\beta \alpha \sigma i \lambda \varepsilon$ ì on his coins (Schürer, History, Vol I (rev), p 227). According to Josephus (Antiq 14.36 citing Strabo of Cappadocia in an otherwise unpreserved passage), this same monarch sent a gift to Pompey which bore an inscription reading

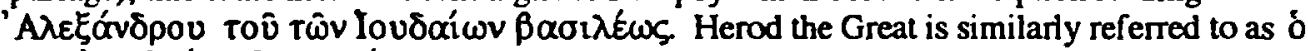

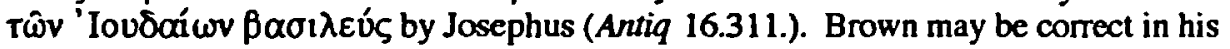
suggestion that the tite may have been kept alive during the Roman governorship as a designation for the expected liberator' (Gospel According to John, p 851).
} 
doubtlessly know of other kingly claimants who had been executed for their aspirations ${ }^{1}$; the precariousness of Jesus' position would be only too apparent.

Faced with such a loaded question, Jesus' reply takes on extreme importance yet the precise meaning of $\Sigma \grave{v} \lambda \varepsilon$ ḱ Some scholars have taken it as a denial ${ }^{2}$; others as a full admission ${ }^{3}$, though if that is the case, it is difficult to see why the chief priests supply further charges and why Jesus is not sentenced immediately. The majority of commentators have understood the reply somewhere between these two extremes: it is 'evasive'4, 'non-committal'5 or, with Taylor, 'it is an affirmative which implies that the speaker would put things differently'6. Pilate has completely misunderstood Jesus' messiahship in terms of political or materialistic kingship. Jesus will not deny his messiahship, yet neither will he accept the Roman's distortion of it. Before the Jewish council, although Jesus admitted that he was 'the Christ, the Son of the Blessed', he immediately went on to redefine his identity in terms of the 'son of man' (14:62), a title which was less easily misinterpreted in a military or political sense? Jesus makes no such redefinition before Pilate; the Roman's misunderstanding of Jesus' kingship will continue to dominate the passion narrative until Jesus is crucified as a result of it.

Without waiting for Pilate's response, Jesus' opponents accuse him of many things ( $\pi \circ \lambda \lambda \alpha$ ), again emphasising their desire to see him convicted. To these, Jesus is silent (v.4). The possible LXX background to this feature has already been discussed but in the Markan narrative the silence of Jesus also serves to emphasize dramatically his one reply; it gives Jesus an added sense

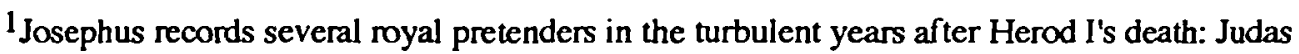
the son of Ezekias (17.271); a slave named Simon (Antiq 17.273-277); the shepherd Athrongaeus ( War 2.60-65). In Antiq 17.285 he writes: 'Anyone might make himself king as the head of a band of rebels whom he fell in with, and then would press on to the destruction of the community, causing trouble to few Romans and then only to a small degree but bringing the greatest slaughter upon their own people'. Such kingly impersonators when caught were dealt with severely by the Romans (17.276). See Hengel, Zealots, pp 290-302, also Horsley/Hanson, Bandits, pp 88-127.

2 Pesch argues that it is a question which amounts to a denial, and that Pilate's use of ôv $\lambda \varepsilon ́ \gamma \varepsilon \tau \varepsilon$ in v.12 also suggests that Jesus has denied kingship, Markusevangelium, p 457.

${ }^{3}$ Eg Piper, 'God's, p 179; Cole, Mark, p 233; Gould, St Mark, p 283.

${ }^{4}$ Van lersel, Reading, p 179.

5 Branscomb, Gospel, p 287.

GTaylor, Gospel, p 579.

7 It was probably an understandable unease with the political insurrectionary connotations associated with the title 'King of the Jews' which deterred the early Christians from using it to describe Jesus. Apart from the Johannine writings and the synoptic passion accounts, where its meaning is refined and qualified, it is scarcely used elsewhere in the NT. See Burkill, 'St Mark's', p 166; Cullmann, Christology, pp $220 \pi$.
} 
of dignity, and, in the light of Jesus' silence in the face of false witnesses in 14:60, it implies that the many accusations of the priests are also false.

To his credit, Pilate seems unwilling to condemn Jesus only on the accusations of his Jewish opponents. His question reflects a Roman governor's typical reluctance to condemn a man who will only utter one ambiguous phrase in his own defence ${ }^{1}$; it does not, however, necessarily

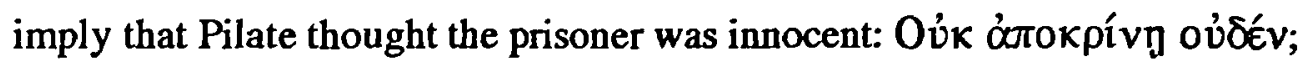

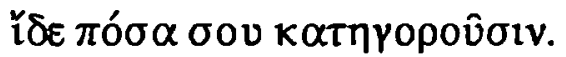

The silence of Jesus is said to amaze Pilate (v.5). Throughout the gospel Mark has repeatedly emphasized the amazement of those witnessing the miracles or hearing his authoritative teaching but 'stresses equally, if not more, the failure of the crowd and of the disciples to understand them ${ }^{2}$. Of the various verbs used to express this amazement $\left(\theta \alpha v \mu \alpha \zeta_{\zeta} \omega, \theta \alpha \mu \beta \varepsilon \varepsilon^{\prime} \mu \alpha\right.$, $\dot{\varepsilon} \kappa \pi \lambda \eta ́ \sigma \sigma o \mu \alpha$, $\dot{\varepsilon} \xi \hat{i} \sigma \tau \eta \mu \mathrm{l})$, the verb which appears here in verse 15 , $\theta \alpha v \mu \alpha{ }^{\prime} \zeta \omega$, appears to be used of those least perceptive of Jesus' identity ${ }^{3}$. We should probably not read a deep religious significance into Pilate's attitude at this point ${ }^{4}$; the verb denotes no more than ordinary wonder or bewilderment at a man facing a death sentence who will not defend himself. Mark shows that even the Roman governor is amazed at Jesus' words yet, like others in the story, has no perception of Jesus' significance.

With verses 6-7 the narrator momentarily moves away from the main action to supply his readers with two pieces of background information. Jesus

\footnotetext{
${ }^{1} \mathrm{Cf}$ the remark of Festus in Acts 25:16, I answered them that it was not the custom of the Romans to give up anyone before the accused met the accusers face to face, and had opportunity to make his defence concerning the charge laid against him'. In the earliest martyr trials the defendant was given three opportunities of changing his or her mind before sentence was passed; Pliny's letters of c AD 110 are the earliest records of such a procedure (x.96.3), though it probably goes back to an earlier period. See Sherwin-White, Roman, p 26.

${ }^{2}$ Best,Mark, $p 60$. For other references to amazement see 1:22, 27 (the verb here may even imply alarm, see Lane, Gospel, p 76), 2:12 (where the Pharisees are also amazed along with the crowd), 6:2 (where Jesus' countrymen are said to be astonished but then take offence at him), 7:37, 10:24 and 26 (where the disciples are amazed but quickly show by their questions that they do not understand), 10:32, 11:18.

${ }^{3}$ It is used in 5:20 of those in the Decapolis hearing Legion's teaching; in 6:6 it is used to describe Jesus' amazement at the disbelief of his countrymen. The final two uses of the verb are of Pilate: in the present context and again at 15:44 where the governor wonders if Jesus is

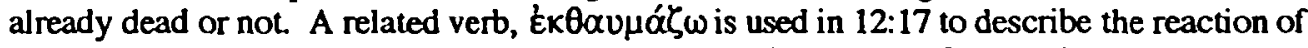
the Pharisees and Herodians to Jesus' answer over paying taxes to Caesar; these two groups continue to be antagonistic towards Jesus.

${ }^{4}$ Many scholars have read a religious connotation into $15: 5$, virtually making Pilate a witness to the divinity of the man before him, eg 'Es zeigt das Aussergewöhnliche, Gottliche an' (Gnilka, Evangelium, p 300); 'It may suggest a superstitious dread' (Johnson, Commentary, p 247). See also Pesch, Markusevangelium, p 458. Nineham asserts that the verb $\theta \alpha v \mu \alpha ́ \zeta \omega$ has 'profound religious connotations in the gospel', Gospel, p 412. In contrast see Gundry, Mark, p 933, who asserts that the word does not imply that Pilate has a sense of Jesus' divine power.
} 
is left with an unresolved capital charge over his head and Pilate continues to wonder whilst Mark describes a passover amnesty and introduces an important character in the trial, Barabbas.

In v. 8 the story continues. The crowd come up ( $\left.\alpha^{\prime} v \alpha \beta \alpha^{\prime}\right)^{1}$ to Pilate's praetorium and ask him to honour his usual custom of releasing one prisoner to them at the feast. Mark's account implies that the amnesty was a custom which either Pilate had introduced himself or had inherited from his predecessors and seen no reason to discontinue 2 . Either way, it shows Pilate willing to please the people and anxious to avert trouble at a festival where spirits might be high and the city crowded to bursting. Any of Mark's readers familiar with Jewish practices would recognize the significance of releasing a prisoner at passover, a feast which itself celebrated release from slavery in Egypt; others would see it as a conciliatory gesture. It is noteworthy, however, that it is not Pilate who makes an offer to release Jesus on the basis of what he has heard in 15:1-5, but the crowd who initiate the discussion.

Mark states simply that the crowd 'began to ask Pilate as he was wont

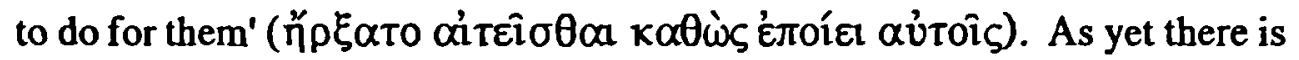
no indication which prisoner the people will choose; the reader is aware of the existence of Barabbas but there is no indication that the crowd is particularly sympathetic towards him. If anything, the appearance of the crowd and the practice of releasing a prisoner would appear to bode well for Jesus. With relatively few exceptions, the Jewish crowds have been spontaneous and enthusiastic supporters of Jesus from the very first ${ }^{3}$; there is no indication that they have turned against him now.

Pilate does decide to link Jesus' fate with the release of a prisoner, but in a particularly calculating way. His offer in v.9 needs to be understood in

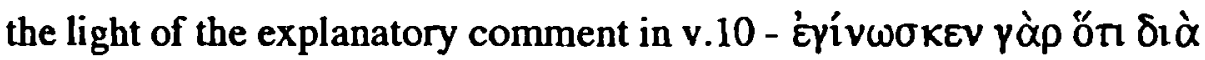

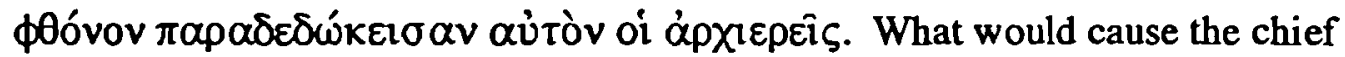
priests to be envious of Jesus? Disputes over religious matters alone might arouse a certain amount of resentment, even hostility, between a popular leader and the priestly aristocracy but the only thing which would arouse envy

\footnotetext{
${ }^{1}$ Since the governor's tribunal was on a raised dais (War 2.301) the use of orvop dus here may symbolically imply that the crowd are coming up to judge.

${ }^{2}$ Although the article is absent, it is clearly the feast ie passover which is meant by $k \alpha \tau \alpha \grave{\alpha} \delta \dot{E}$

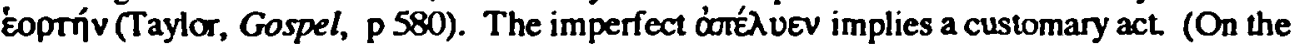
historicity of this custom see chapter 1 ).

${ }^{3}$ In 1:28 Jesus achieves instant popularity, his fame spreading around the whole region of Galilee; this popularity continues in 1:32, 37, 45, 2:2, 13, 3:7-8, 20,4:1, 5:21, 24, 6:33, 34-44, 54ff, 8:1-10,34, 9:14, and in Judaea 10:1, and around Jerusalem 11:18, 12:12, 37. The only places where Jesus was not enthusiastically accepted was in the country of the Gerasenes (5:17) and his own country (6:1-6).
} 
amongst the chief priests would surely be if Jesus' teaching threatened their own privileged position and if he was winning support amongst the people, a support which in Mark's gospel the priests do not possess. This is consistent with the portrait of Jesus painted by the rest of the gospel which repeatedly emphasizes Jesus' popularity with the crowds and the chief priest's fear of an uprising1. Pilate realized that the chief priests had their own motives for handing Jesus over: they were not guided by loyalty to Rome, but primarily out of fear for their own position. Far from proving Jesus' innocence ${ }^{2}$, however, this recognition would convince Pilate that Jesus ought to be dealt with the utmost thoroughness. The case of a possible messianic leader whose influence over the people worried the priests to the extent that they were willing to hand him over to the representative of Rome, a man who had already claimed to be the messiah (14:62), spoke of a 'kingdom'3, and refused to say anything further in his own defence ${ }^{4}$ was not to be dismissed lightly5.

The question of Pilate in Mark's narrative, then, is a test of public support. The crowd has asked for the release of a prisoner and Pilate offers

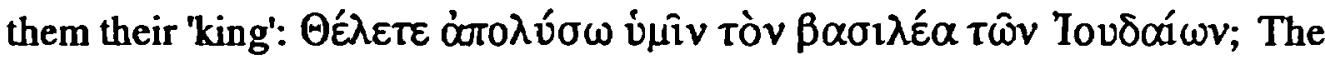
tone of the question is mocking; the Jews are an occupied people, they can have no king. But it is primarily a challenge: who will support this messianic leader? The supporters of messianic uprisings suffered along with their leaders; anyone openly supporting Jesus would suffer the same fate ${ }^{6}$. This explains why the crowd in Mark's gospel so quickly deserts its one-time hero and allows the chief priests to influence it into shouting for Barabbas (v.12). The verb $\dot{\alpha} v \alpha \sigma \varepsilon i \omega$, to stir up, again underlines the guilt of the chief priests

\footnotetext{
'Eg 14:2, 11:18, 12:12. In 1:22 the people declare that the scribes teach without authority, in contrast to Jesus. Gundry suggests that the chief priests were envious of Jesus because the crowds regarded him as their king (Mark, p 927). On the religious authorities see Kingsbury, Conflict, pp 14-21; Cook, Mark's Treatment.

${ }^{2}$ There does not seem to be any justification for Hendrickx's comment on v:10, the is therefore depicted as aware of the innocence of Jesus' (Passion, p 65); see also Hooker, Gospel, p 369.

${ }^{3} \mathrm{Eg}$ 4:11, 26, 30, 10:14, 15, 23, 24, 25.

${ }^{4}$ Sherwin-White writes 'Since there was no defence, Pilate had no option but to convict. That was the essence of the system', Roman, p 25.

5 On a different level, the use of $\$ 06$ vos negates the whole findings of the Sanhedrin in 14:5365 . The sentence of a judge who is motivated by envy is worthless (Liihrmann, Markusevangelium, p 256).

6The suggestion that the use of the term 'King of the Jews' was an attempt to enlist the patriouc feelings of the multitude on the side of the prisoner does not seem to take enough account of the dangerous connotations which the title would arouse in the first century; see for example Plumtre, St Mark, p 245; Pesch, Markusevangelium, p 464. Cole (Mark, p 235) accepts that the tille strs up the bittemess of the crowd but attributes this to a lack of political shrewdness in Pilate.
} 
who prey on the people in their weakness ${ }^{1}$. There is no contradiction between the previous support of the crowd and its present rejection of Jesus: in the same way that Peter abandoned Jesus when the pressure was too much (14:66-72), the crowd too abandons Jesus under political pressure. It is perhaps significant that Peter's denial of Jesus has been inserted directly before the trial before Pilate (14:66-72); all of Jesus' supporters are deserting him.

Far from being a tool in the hands of the chief priests and crowd in these verses, Pilate is very much in control. He recognizes the self-interest in the actions of the chief priests but also realizes that Jesus is a potential threat to law and order. When the people ask for his usual favour, he skilfully and ominously highlights the political charge resting on Jesus, and the people are scared into backing the candidate of the chief priests (v.11). But who exactly is Barabbas? Mark's description of this character is extremely oddly constructed:

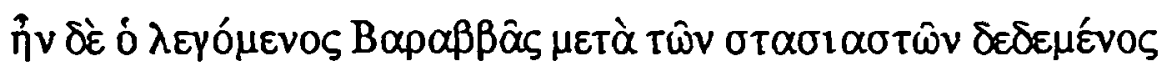

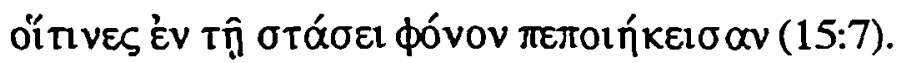

'And among/in the midst of the rebels in prison, who had committed murder in the insurrection, there was a man called Barabbas'. That is, unless Mark is being extremely careless, he seems to be carefully distinguishing between Barabbas and those who have committed murder during an obviously wellknown insurrection ${ }^{2}$. Had the evangelist wanted to link Barabbas himself with murder and insurrectionary activity a more obvious expression would have been something like $\dot{\varepsilon} \varsigma \tau \hat{\omega} v \sigma \tau \alpha \sigma 1 \alpha \sigma \tau \hat{\omega} v^{3}$. Thus Mark's report fixes the time of Barabbas' imprisonment but does not specify his crime, nor how far legal proceedings had progressed against him. Pilate's attempt to gauge support for Jesus therefore has not necessarily lost him a dangerous political prisoner. The references to 'the rebels' and 'the insurrection' in connection with Barabbas, however, tar him with an insurrectionary brush, further discrediting the choice of the chief priests ${ }^{4}$.

\footnotetext{
${ }^{1}$ All the more so if the verb has the nuance 'o lead astray' as in Is 36:18; Pesch, Markusevangelium, $\mathrm{p} 465$. See Bornkamm, TDNT vol vii, $\mathrm{p} 98$.

${ }^{2}$ Possibly Mark's readers would know of an insurrection under Pilate; exactly what this involved and whether it was identical with any of the tumults known from Josephus is unknown.

${ }^{3}$ Winter, Trial, p 97 . Menzies, cited by Rawlinson (Gospel, p 228) suggested that Barabbas had become accidentally connected with the rioters. Pesch suggests that the strange formulation may suggest that Barabbas was innocent (Markusevangelium, p 462-463).

4 The scene with Barabbas may illustrate a much deeper theological point. The actual phrase

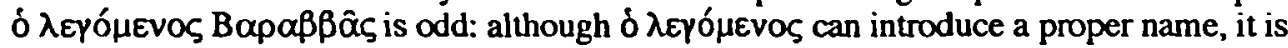
normally preceded by a personal name and followed by a descriptive title (eg Mt 1:16, 4:18, $10: 2,27: 17,22)$. The name Barabbas would appear to mean 'son of a/the father'; Bar Abba is
} 
Had the Markan Pilate regarded Jesus as innocent and wished to release him, now would have been the obvious time. Having discovered that the crowd are not willing to stand up for Jesus, Pilate could have dismissed them and released both Barabbas and Jesus as a double gesture of Roman good will at the festival. Yet he does not do this. In fact nothing in Pilate's previous behaviour has given any hint that the governor does regard Jesus as innocent. He has shown amazement that the prisoner will not speak on his own behalf against his Jewish accusers; yet Jesus has come before the govemor condemned by a Jewish court after admitting his messiahship. Mark's readers would know that unless strong evidence to dispute the charge was forthcoming any Roman governor, in the interests of law and order, would have little choice but to convict a man making such claims.

But the Markan Pilate is in a delicate position. The evangelist has pointed out several times that the events of Jesus' last hours occur at the feast of passover: 14:1, 12, 15:6. The feast celebrated liberation from slavery in Egypt and, at a time of foreign occupation, messianic expectations might be expected to be at their height. The chief priests have already expressed their fears that to arrest Jesus and kill him during the feast might provoke a tumult of the people (14:2). So too now, although the people have publicly sided with Barabbas against Jesus in front of Pilate, a heavy handed approach could provoke rioting later, especially in view of Jesus' previous popularity. The dilemma confronting the Markan Pilate therefore was how to deal with Jesus without disturbing the peace. The governor hits upon an ingenious solution: he swaps roles, putting the people in the position of the judge, and asks them what should be done with Jesus. The voice of the people, though not sufficient to decide the outcome of a trial, was valued by Rome in determining the political feasibility of a verdict ${ }^{1}$. If the crowd itself could be made to acquiesce in Jesus' execution then there could be no danger of later displays of discontent against Roman harshness. Pilate puts the people on the spot,

occasionally found in the Talmud as a designation for some of the Rabbis (Taylor, Gospel, $\mathrm{p}$ 581; Gnilka, Evangelium, p 301, n. 30). Certain codices and minuscules give the name as Barrabas, which would mean 'son of a/the teacher', but this reading is 'not probable' (Taylor, $p$ 581). Ironically the Jewish people, stirred up by the chief priests, reject the true Son of the Father in favour of another 'son of the father' who has somehow become mixed up in insurrectionary activity; the people are looking for a 'Son of the Father' as their leader but misunderstand the nature of his role and mistakenly chose the wrong one. But there is also the beginning of a second theological theme here, one which will be developed further in Mt 27:17: out of Jesus' death comes the release of another. The vague name Barabbas is true of all people; Jesus' death liberates all people as was expressed in 10:45 and 14:24 (see van Iersel, Reading , pp 180-181, who however presses the point too far. Jesus is not put to death in place of Barabbas in Mark; it is only in Matthew that an explicit choice between the two men is offered).

1Bammel, Trial', p 431. 
issuing a direct challenge to their political allegiance: What then shall I do with the man whom you call the King of the Jews?

Whatever their historicity, such tactics would not be unknown or uncommon to Mark's readers. Two examples from Josephus may help to illustrate the way in which Mark's first century readers might have understood Pilate's actions here. The first occurs in Antiq 13.288ff. The envy of the Jews, particularly the Pharisees, had been aroused against the Jewish King Hyrcanus because of his successes and those of his sons (\$288). At a feast a Pharisee named Eleazar said that if the King wished to be righteous he should give up the High Priesthood and be content with governing the people ( $\$ 291)$, a remark which provoked the other Pharisees to indignation and Hyrcanus to fury. A Sadducee named Jonathan persuaded Hyrcanus that all the Pharisees were of that opinion, urging the king that this would become clear if he were to ask them what punishment Eleazar deserved. Hyrcanus followed this advice, saying that 'he would be convinced that the slanderous statement had not been made with their approval if they fixed a penalty commensurate with the crime' (\$292). Unfortunately for those Pharisees concerned, they thought that death was too harsh a penalty and suggested stripes and chains. Their leniency angered Hyrcanus who assumed that the man had slandered him with their approval and from that time onwards sided with the Sadducees. The second narrative comes in the reign of Herod I, Antiq 17.155-164. After his eagle had been pulled down from above the temple and hacked to pieces, Herod summoned the Jewish officials to the amphitheatre, telling them how much he had done for the nation and that pulling down the eagle was sacrilege. 'Because of his savage state and out of fear that in his fury he might avenge himself upon them, those present said that the things had been done without their consent, and it seemed to them that the perpetrators should not be exempted from punishment' (\$164). Because the Jewish officials had been quick to condemn those responsible, Herod dealt mildly with the officials themselves. In the parallel description in War $1.654 \mathrm{ff}$ it is the people who are summoned and ask Herod to deal only with the perpetrators. In both the above stories a group of people is forced to pass a judgement on a crime; this is then used by the Jewish ruler to assess their complicity in the affair. Furthermore, in the second example, the Jewish officials under Herod could hardly have later complained at the King's harshness towards those who pulled down the eagle since they themselves had sanctioned such treatment and were only too pleased to be able to escape the slur of complicity and resulting punishment themselves. In neither of the above examples is the behaviour of the ruler a sign of weakness. It is rather a deliberate challenge to the 
allegiance of their subjects; an attempt to make them part of the decision which they then have no alternative but to accept.

Pilate's question has exactly the same motivation: it is an attempt to test the allegiance of the people and to force them to become part of the decision, thereby implicating themselves ${ }^{1}$. But it is also cleverly constructed

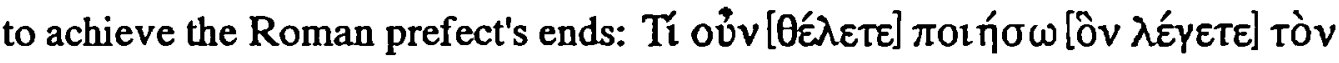

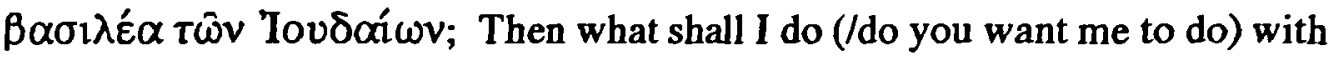
[the man whom you call] the King of the Jews? (v.12) ${ }^{2}$. Again Pilate is using the potentially dangerous political title: it also shows Pilate's scorn for the futile messianic expectations of a subject people. But this time, by the use of ôv $\lambda \varepsilon ́ y \varepsilon \tau \varepsilon$, he has personalized it: by their reply the Jewish crowd will reveal whether they really do accept Jesus as their King or not. The word Gé $\lambda \varepsilon \tau \varepsilon$ stresses that the decision rests with the crowd, they must take responsibility for the consequences of their judgement ${ }^{3}$. If Pilate had asked 'What shall I do with the one you call the religious teacher? the possible answers would have been much wider. In response to Pilate's actual question, however, the people had no choice unless they too wanted to be implicated in insurrectionary activity, or at best be seen as supporting a kingly aspirant. Like the Pharisees at Hyrcanus' banquet, the severity of the punishment demanded by the people will illustrate how far they are from siding with the prisoner. The people are cornered; they know what penalty Rome inflicts on political agitators and they accordingly cry for crucifixion (v.13). Like the disciples earlier, fear and weakness lead the crowd to abandon Jesus ${ }^{4}$.

\footnotetext{
${ }^{1}$ Hendrickx argues that a Roman governor would not be likely to ask the people what to do with an accused prisoner, Passion, p 65. This seems to be too literal a reading of the text; we would not expect either John Hyrcanus or Herod I to ask their subjects' opinions regarding legal issues, but the examples from Josephus show them asking those opinions for political effect. In all these cases, the actual historicity of the events is of secondary importance to the effect which the narrator wishes to produce.

${ }^{2}$ This seems to be the natural reading of ôv $\lambda E ́$ YeTE.

${ }^{3}$ The readings $\theta \dot{e} \lambda \varepsilon T \varepsilon$ and ôv $\lambda \lambda^{\prime} \gamma \varepsilon T \varepsilon$ are uncertain (both C ratings in the UBS 4th Edition). The quality of the witnesses for their omission is fairly good $(\aleph \mathrm{B}, \mathrm{C}, \mathrm{W}$ for omission of

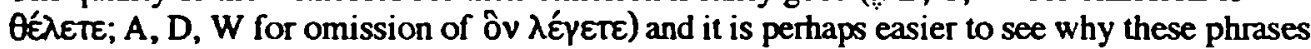
should have been added to the text, possibly from $\mathrm{Mt}$ 27:22, rather than removed. If not original they certainly fit the sense of the question which would then read simply 'What then shall I do with the King of the Jews?' However, it is probably better to accept the UBS reading and regard them (tentatively) as an original part of the text.

${ }^{4}$ Like the seed sown on rocky ground or amongst thoms, the crowd fall away as soon as difficulties arise (4:15-19). There are also parallels here with 8:34-38 where Jesus tells the multitude and his disciples that discipleship involves taking up the cross, 'for whoever is ashamed of me in this adulterous and sinful generation, of him will the Son of Man also be ashamed, when he comes in the glory of his Father with the holy angels'.

It is common amongst commentators to distinguish between various crowds in Mark's gospel; thus the crowd at Jesus' entry into Jerusalem are seen as Galilean supporters whilst those in the present scene are Jerusalemites or supporters of Barabbas (see for example France, Divine, p 87; Meyer, Ursprung und Anfänge des Christentums i, p 195; Rawlinson,
} 
The Markan Pilate seems to step back momentarily from his former

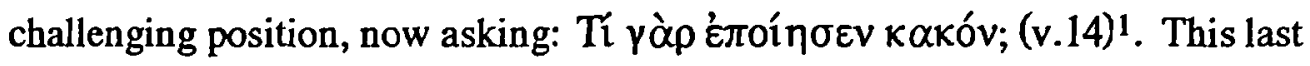
question is heavily ironic in that Mark's Roman governor seems to be more open to Jesus' innocence, even at this late stage, than the Jewish crowd. Although portrayed as a strong political manipulator throughout this scene, Mark's Roman is clearly not as aggressively hostile towards Jesus as his compatriots and their leaders. It is almost as if Mark has used Pilate to hold up the proceedings for a moment, asking the people to think about what they are doing. They, however, refuse to answer, shouting all the more for crucifixion. Mark's readers are perhaps intended to realize that Jesus has not done any evil and so the crowd cannot reply to Pilate's question.

The Roman governor is now in a strong position: as a messianic claimant, Jesus had to be removed but the major obstacle, public outrage, has now been eliminated; the people could hardly riot over someone whose death they had demanded. Verse 15 is therefore again full of Markan irony: Pilate is satisfying the demands of the crowd, but these are demands which he has engineered and which suit his own purposes 2 .

Pilate sends Jesus to be flogged ( $\left.\phi p \propto \gamma \varepsilon \lambda \lambda{ }^{\circ} \omega\right)^{3}$; this could be given as a punishment in its own right ${ }^{4}$ or, as here, formed the usual preliminary to crucifixion5. Mark's readers would be well aware of the horrors of this degrading torture. No further details are necessary; the evangelist is not interested in rousing support for Jesus by emphasising the extent to which he

Gospel, p 195). Historically there may have been different groups who heard Jesus, some more enthusiastic than others, but in the context of Mark's narrative it is the same general 'crowd' who followed Jesus throughout his ministry who now reject him.

${ }^{1}$ Mark shows a distinct liking for groups of threes: three questions here, Jesus is mocked three times, throe passion predictions, three sleeping disciples in Gethsemane and Jesus returns three times, three women at the tomb etc; see Burkill, Mark's, p 256; Petersen, 'Composition ', pp 185-217. (Though see also Neirynck, Duality).

${ }^{2}$ No death sentence is necessary in Mark's account since this has already been pronounced by the Jewish council in 14:64; see Gnilka, Evangelium, p 303.

${ }^{3}$ This appears to be the Latinized version of the verb $\mu \alpha \sigma \pi \gamma$ of $\omega$, the usual Greek word for 'flogging' or 'scourging' found throughout Josephus' writings and used in Jn 19:1, Barrett, Gospel According to John, p 539.

${ }^{4}$ For example the case of Jesus ben Ananias who was scourged by Albinus before being released (War 6.5.3). On several occasions during the Jewish revolt, according to Josephus, it was used to produce terror in the compatriots of the one scourged: eg War 2.612, 7.200, Life 147; Jewish fear of the lash is expressed in War 6.143. Jewish usage limited flogging to forty strokes, in practice thirty-nine (2Cor 11:24, Dt 25:3); the Romans however had no limit and people could often die under the torture (War 7.373, Eusebius $H E$ 4.5.4). It was a punishment from which Roman citizens, as with crucifixion, were exempt (Acts 22.25).

${ }^{5}$ See Josephus, War 2.306, 308, 449, 5.449, 7.200-202; Livy 1.26, 33.36; Philo, In Flaccum 9.72; Seneca, Ad Marciam 26.3; A puleius, Metamorphoses 8; Dionysius of Halicamassus 7.69. Whether the scourging took place before the crucifixion, on the way to the place of execution or actually on the cross varied. 
was physically abused. After having Jesus scourged, Pilate hands him over to crucifixion. The word $\pi \alpha \rho \varepsilon \delta \delta \omega \kappa \varepsilon v$ in 15:15 echoes that in 15:1 and is reminiscent of the passion predictions in 9:31 and 10:33-34. Pilate has performed his role in Jesus' passion and now passes him on to the next stage in his execution.

\section{Conclusion}

Pilate in Mark's gospel is not a weak governor, bowing to public pressure and the demands of the chief priesthood. Instead he is a skilful politician, manipulating the crowd to avoid a potentially difficult situation, a strong representative of imperial interests. Although Mark clearly lays primary guilt for Jesus' death upon the Jewish leadership, Pilate is not exonerated. He plays a vital part in the chain of events leading to the crucifixion and shares the guilt which that involves. This is perfectly in keeping with the third passion prediction in which there is no hint that Jesus' Gentile judge will be favourably disposed towards him: 'the Son of Man will be delivered to the chief priests and the scribes, and they will condemn him to death, and deliver him to the Gentiles; and they will mock him and spit upon him and scourge him, and kill him; and after three days he will rise' (10:33f). In his death not only is Jesus deserted by his closest supporters and the crowd but the whole political world of first century Palestine, both Jewish and Roman, have sided against him. The Jewish leadership have arrested and condemned him but Pilate allows Jesus to be sent to his execution.

This portrayal of Pilate serves two important functions within the Markan narrative. The first ties in with persecution, an important background to the gospel. 4:17 speaks of followers of Jesus who fall away 'when tribulation or persecution arises'; 8:34-38 counsels disciples to take up their cross and promises that those losing their lives for Jesus and the gospel will be rewarded; 10:30 speaks of persecutions now, 'in this time'1. The clearest reference is in 13:9-13:

'But take heed for yourselves; for they will deliver you up to councils; and you will be beaten in synagogues; and you will stand before governors and kings for my sake, to bear testimony before them. And the gospel must first be preached to all nations. And when they bring

\footnotetext{
${ }^{1}$ The two storms at sea may also be to illustrate the way in which Jesus rescues his community in persecution, 4:35-41, 6:45-52. See generally van Iersel, 'Persecuted Community?'.
} 
you to trial and deliver you up, do not be anxious beforehand what you are to say; but say whatever is given you in that hour, for it is not you who speak, but the Holy Spirit. And brother will deliver up brother to death, and the father his child, and children will rise against parents and have them put to death; and you will be hated by all for my names' sake. But he who endures to the end will be saved'. (RSV) Rather than an apocalyptic warning of future persecutions, this passage appears to be referring to a present reality. Mark is writing for people who have been made to stand before governors and kings, who have been brought to trial and hated because of the Christian gospel. As M. Hengel writes: Is it not obvious that here Mark has in mind those cruel events of 64 , when there was the first mass killing of Christians? ... The emphatic theology of suffering and the cross in the gospel has its very specific Sitz im Leben here' ${ }^{1}$. One of the aims of Mark's work was to strengthen such people, to show them that Jesus predicted their persecution; the story of Peter's denial and subsequent restoration (16:7) shows that there can be forgiveness even for those who have denied Jesus; and parables of growth and Christian community show the continuance of Christianity beyond present troubles. Into this framework Mark's picture of Jesus' hearing before Pilate fits perfectly. To have shown Jesus standing before a weak impotent governor determined to release him would have been far removed from the experiences of Mark's readers, some of whom may have experienced the harsh reality of a Roman hearing themselves. But to portray the Roman governor in a strong position, preying on the fears and weaknesses of the people, would have far more contemporary relevance. Mark shows that all that the Christian community in Rome have recently suffered, and possibly feared might break out again ${ }^{2}$, had previously been endured by their master. Jesus' strength and courage at the hands of a harsh Roman governor would fortify his followers and help them to come to terms with their own hardship. He too had been humiliated (14:65, 15:16-20, 24ff) and betrayed by an intimate friend (3:19) as

\footnotetext{
${ }^{1}$ Hengel, Studies, p 24. The primary texts describing Nero's persecution are: Tacitus, Ann 15.44; Suetonius, Nero 16; Eusebius, HE. 2.25; and Sulpicius Severus, Chronicle 2.29 (the latter, writing in the fifth century, was heavily dependent upon Tacitus for his account).

2Tertullian's reference to an institutionem Neronianum (Ad Nationes 1.7, Apol 5) and Severus' rather vague reference to edicts (Chron 2.29.3) have led some scholars to suggest the existence of an edict of Nero (or at latest Domitian) forbidding the practice of Christianity anywhere in the empire. However, no inscription referring to it has ever been found, nor does Pliny appear to be aware of such an edict (Letters x.96/7) and Tertullian's phrase may simply mean 'the practice adopted by Nero' (de Ste Croix, 'Why Were', $p$ 14). Yet even if no formal edict outlawing Christianity was passed by Nero, the Christian community in Rome would still feel in a vulnerable position and might fear further persecutions. See Hengel, Studies, p 24; Best, Mark, p 52.
} 
community had been $(13: 12 f)^{1}$. Mark shows that discipleship may involve persecution and harsh treatment by Rome but this was not only foretold but also endured by Jesus in his earthly life.

Mark's hearing before Pilate, along with the Jewish trial, illustrates a second important point for earliest Christianity: although crucified as an insurrectionary, Jesus was innocent of all charges and goes voluntarily to his death as the righteous one of God. Mark shows that neither the Jewish nor the Roman hearing held any weight. The Jewish proceedings were a sham, the judges motivated by envy and a desire to be rid of Jesus at all costs, men who would stoop to childish mockery of their victim. The Roman hearing before Pilate, though before a harshly manipulative and shrewd governor, was based on a misunderstanding of kingship. Mark's corrupt Jewish court presented Jesus to the governor as one condemned for his messianic claims, claims which Pilate interpreted as threatening Roman stability and interests. It is also significant that Pilate only ratified the existing sentence; he did not initiate it; Rome had not previously had any reason to arrest Jesus as a political activist but simply acted on the Jewish findings. The reader, however, knows that Pilate is mistaken in his acceptance of the Jewish condemnation and that Jesus was not claiming an earthly political kingship, involving territorial conquest and a threat to Roman order in the province, as the Roman governor supposed. This would be an important apologetic point for first century Christians accused by their opponents of following a failed Jewish revolutionary who met a shameful end on a Roman cross. Scholars such as Brandon and Nineham $^{2}$ are right to see Mark's account of the hearing before Pilate as an apology for the crucifixion, but Mark does not achieve his purpose by emphasising the weakness of Pilate as they suppose. Brandon in particular admits that the traditional reading of Pilate in this scene portrays him as impossibly weak and stupid and is forced to conclude that Mark wrote for 'simple-minded' people. Mark's handling of his material is much more sophisticated than this: he presents the reader with a credible representative of Roman rule, yet skilfully arranges the narrative on two levels. Jesus stands before Pilate in silence, the governor's misunderstanding of his kingly identity sends him to his death; yet the reader recognizes what Pilate is hardly interested in, that Jesus is innocent. Although Jesus was crucified as an insurrectionary, Mark's gospel shows that the execution was based on

\footnotetext{
${ }^{1}$ See Tacitus' description, Ann 15.44.2-5: some of the Christians informed on others and all were subjected to humiliating deaths, some were crucified.

${ }^{2}$ Brandon, Jesus; Nineham, Gospel, p $411 \mathrm{f}$.
} 
corruption and misunderstanding: Christians followed the innocent son of man who gave his life as a ransom for many (10:45); not a failed political leader, but the risen Lord of Easter Sunday 1.

${ }^{1}$ An historical appraisal of the Roman trial of Jesus will be left until after the characterization of Pilate has been examined in all four gospels. 


\section{CHAPTER 5}

\section{Pilate in Matthew's Gospel}

Turning to Matthew's gospel, we are dealing with a book written for another early Christian community but in a different location and facing its own particular set of problems. Virtually all scholars are agreed that Matthew, like Mark, was composed in an urban environment, possibly for a community which included several wealthy members ${ }^{1}$. This has traditionally been located at Antioch, the capital of the province of Syria and the fourth largest city in the Roman Empire2. In favour of Antioch is its Greek-speaking Gentile character along with its large Jewish population; the long existence of Christianity in the city (since the 30s according to Acts 11:19-26) and the fact that Matthew's gospel seems to have been known and possibly quoted in the early second century by Ignatius, the bishop of Antioch ${ }^{3}$. Although this is still a widely held view 4 , a growing number of scholars suggest that the gospel may have originated much closer to Palestine, possibly in a city of Upper Galilee or Syro-Phoenicia 5 . In support of such a location is the close contact

\footnotetext{
${ }^{1}$ In favour of an urban environment is the fact that the word $\pi$ ó $\lambda_{15}$ occurs 26 times in Matthew, compared to 8 times in Mark, suggesting that Matthew had a particular interest in city life. See Kingsbury, 'Conclusion', p 264.
}

In support of the weal thy status of some of the members of Matthew's community is the fact that Matthew seems less concerned for the poor than either Mark or Luke; for example where Luke has 'Blessed are the poor', Matthew has 'Blessed are the poor in spirit ' (both are probably dependent upon the same source, Q. Mt 5:3, Lk 6:20). Matthew also contains several references to money and it is striking that he always uses higher denominations than those found in Mark or Luke; for example compare Mt 25:14 with Lk 19:11-17. The reference in 10:9 to 'gold' is absent from both Mark and Luke. See Kilpatrick, Origins, p 124.

${ }^{2}$ For a vivid description of city life in Antioch at the time see Stark, 'Antioch', pp 189-210.

${ }^{3}$ Schoedel suggests that Ignatius knew and quoted the same tradition as Matthew but that he did not have access to the gospel of Matthew in written form, 'Ignatius', pp 175-176.

Conversely Meier, 'Matthew', pp 178-186, argues that four texts from Ignatius' letters are clearly dependent on Matthew's gospel - Sm 1:1, Ph 3:1, Pol 2:2 and Eph 19:2-3 (the latter being a midrash on Matthew's 'star of the magi). See Massaux, Influence, pp 94107, who discusses Matthean texts showing probable or doubtful influence on Ignatius.

${ }^{4}$ The classic exponent of this view is Streeter, Four Gospels, pp 500-528; more recently see Meier, 'Matthew'; Luz, Matthew, pp $90 \mathrm{ff}$.

5 Upholders of this view include Kilpatrick, Origins, pp 133-134, who argues for the Tyrian coastal cities; Hengel, Judaism, vol 1, p 105, who argues for Palestine; Segal 'Matthew's', pp 25-29, who, on the basis of Mt 10:28, argues for a loosely confederated group of congregations in Galilee and Syria between which missionaries were constantly on the move; White 'Crisis', pp 211-247, who argues for a setting somewhere along a Syro-Phoenician arc stretching from Upper Galilee to Coele Syria; Dunn, Partings, pp 151 ff.

Other suggestions include Alexandria (Brandon, Fall, p 221, and van Tilborg, Jewish Leaders, p 172); Caesarea (Viviano, 'Where Was', pp 182-184); and Transjordan, particularly Pella (Slingerland, 'Transjordanian Origin', pp 18-28). 
it would afford with emerging rabbinic Judaism (a contact for which there is very little evidence at Antioch ${ }^{1}$ ) and the fact that the gospel must have originated somewhere where Jewish influence was strong enough to bring serious trouble to Christian believers $(10: 17,23)^{2}$. Although certainty is impossible, this geographical area does make good sense of the pictures both of Judaism and of Pilate which emerge from Matthew and will be taken as the general area of origin in the following discussion.

An important consideration regarding the dating of Matthew's gospel is the precise relationship between the group of Christians to which the author belonged and Judaism. Both the author himself and those for whom he writes appear to be Jewish Christians ${ }^{3}$. Yet throughout the pages of his gospel, the author displays an extremely vehement hostility towards non-Christian Jews, especially Pharisees and the Jewish leadership ${ }^{4}$. Although some scholars suggest that this conflict arises because Matthew's community still regards itself as part of Judaism ${ }^{5}$, the majority argue that by this time it had begun to think of itself as distinct and had recently withdrawn from or been expelled by the local synagogue ${ }^{6}$. The continual references to 'their' synagogue and the

\footnotetext{
'Segal, 'Matthew's', p 26; the authority of Yavneh took some time before it was recognized in the diaspora, see Dunn, Partings, pp 232, 322 n.6.

${ }^{2}$ Further arguments which are often brought against Antioch are the fact that the author of the gospel seems completely unaware of Paul's letters and his doctrine of righteousness apart from the law (although the implication of Gal 2:11-14 is that Paul lost support at Antioch and so abandoned it as a base) and, more importantly, the differences between the Christianity reflected in the gospel and that of Ignatius in his letters (see White, 'Crisis', p 228). Hengel has shown that the fact that the gospel was written in Greek does not necessarily exclude a Palestinian origin, Judaism, vol 1. Furthermore Matthew has added a reference to SyroPhoenicia in 4:24 which has no parallel with Mark and has omitted the reference to the SyroPhoenician woman (Mk 7:26), describing her instead as a 'Canaanite woman' (15:22), possibly because the story might have been offensive to his readers; see Kilpatrick, Origins, pp 132133.

${ }^{3}$ In contrast to Mark, the author of Matthew's gospel does not need to explain Jewish customs to his readers, as a comparison of Mt 15:1 with Mk 7:1-4 shows.
}

It is assumed in this discussion that Matthew the tax-collector with whom the gospel is traditionally associated was not the author (against Goodspeed, Matthew, and Gundry, Matthew, pp 609-622). Papias, cited by Eusebius (HE3.39.16), claimed that Matthew copied oracles in the Hebrew language, but that everyone interpreted them as he was able (see also $H E$ 5.8.2 and 3.34.5-6). Since the gospel was written in Greek and it is inconceivable that an eyewitness would be so dependent on Mark, it is extremely unlikely that this collection of oracles was our Gospel of Matthew; see Luz, Matthew, pp 94ff for a fuller discussion of the author's identity. Meier goes against the prevailing view in his suggestion that the author of Matthew's gospel was a gentile, 'Matthew', pp 625-627.

${ }^{4}$ See for example $21: 28-32,33-46,22: 1-10$, chapter $23,27: 25$. It is also clear from the gospel that the Matthean community are suffering persecution at Jewish hands, see 5:10f, 44, 10:17f, $23,28,32 f, 39,13: 21,24: 9 f$. See Hare, Theme.

${ }^{5}$ Eg Segal, 'Matthew's', who claims that 'in spite of their Christian confession, Matthean Christians are within the spectrum of Jewish law observance. What they oppose is Pharisaic interpretation of the law and their claim of authority to interpret the laws' (p 31). See also Dunn, Partings, pp 151-156, 213-215.

${ }^{6}$ Eg. Gundry, 'Responsive Evaluation', pp 62-67; see especially Stanton, Gospel, pp 113-281. 
anti-Jewish tone of the gospel seem to support this suggestion 1 . Yet it would perhaps be anachronistic to see too rigid a distinction between what was inside and outside Judaism at this point. Matthew's gospel seems to reflect the turbulent times towards the end of the first century when the early church came into conflict with emerging Rabbinic Judaism. The two groups still held much in common - culture, tradition, importance of the Law - but were bitterly divided over their interpretation of that Law and the place and significance of Jesus of Nazareth within it. The gospel is generally dated somewhere between AD 80-902.

The Gospel of Matthew, therefore, was probably written in Galilee or lower Syria in the penultimate decade of the first century and reflects the growing crisis between the Jewish synagogue and the early Christian communities in the restructuring of Jewish society following the fall of Jerusalem.

Pontius Pilate is referred to three times in Matthew's gospel. His first and most extensive appearance is during the Roman trial narrative (27:1-26). He is mentioned again in 27:58 when he allows Joseph of Arimathaea to take Jesus' body and a third time in 27:62-66 when he grants the chief priests and Pharisees a guard to watch over the tomb. The text for the trial scene is as follows:

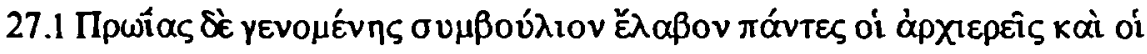

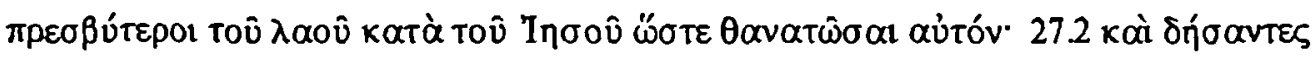

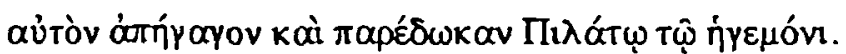

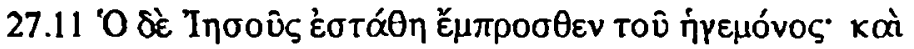

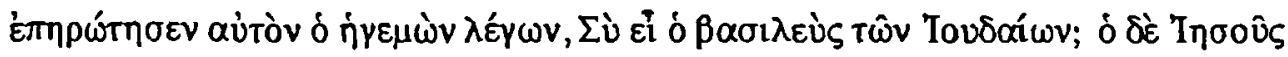

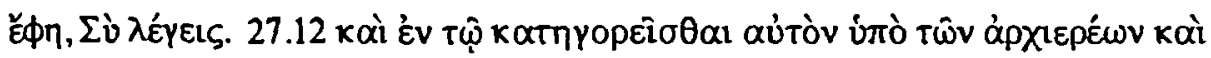

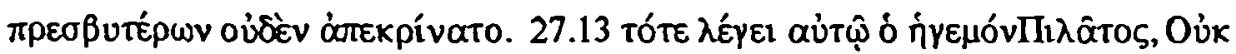

\footnotetext{
${ }^{1}$ See for example the contrast between 'their synagogue' and 'my church' in 16:18, or 21:43.

2 'Local disputes such as that reflected in Matthew's gospel probably necessitated the formulation of the birkath ha minim, the formal exclusion of Christians and heretics from the synagogue, probably in the late first century. For some of the problems associated with this decree see the chapter on 'Pilate in John's Gospel'. See also Alexander, 'Parting', pp 1-25; and for important bibliography on this subject see Dunn, Partings, p 320, n. 46. There are other reasons for this dating. Jerusalem already seems to have fallen, 21:43, 27:25. If 27:24-27 refers to the Jewish poll-tax, then the gospel (or at least the traditions behind it) must date from before AD 97 when the tax was repealed by Nerva. Davies suggests that the Sermon on the Mount is a Christian answer to Jamnia, which would put the gospel shortly before or after the turn of the century, Setting. pp 256-315.
} 


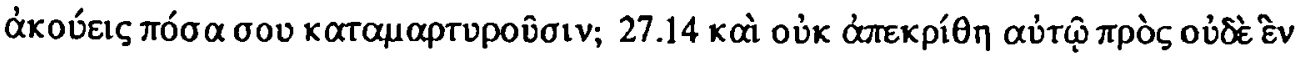

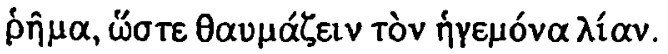

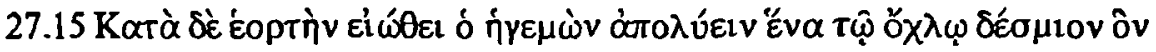

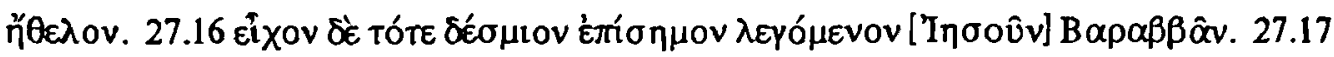

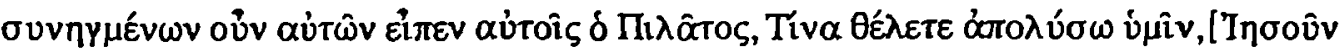

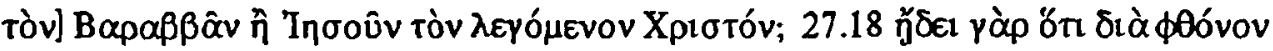

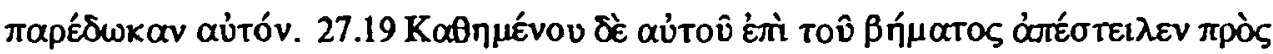

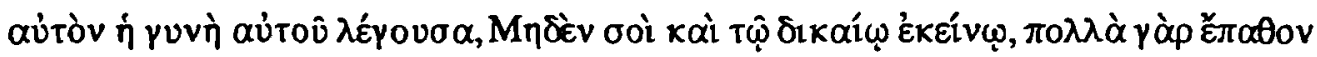

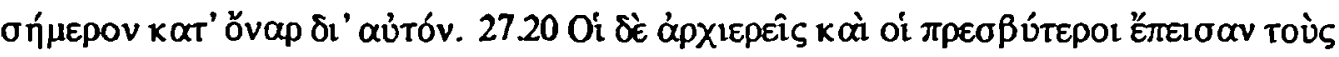

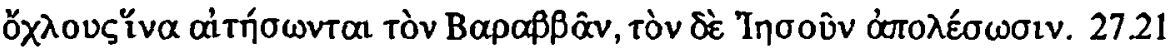

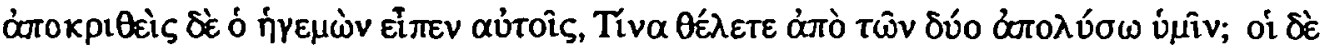

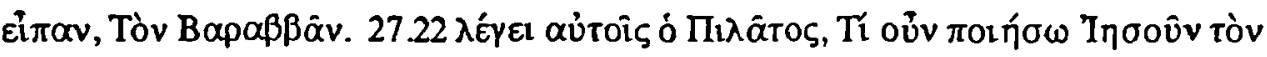

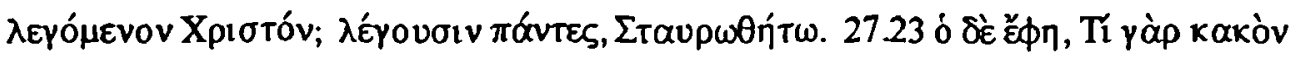

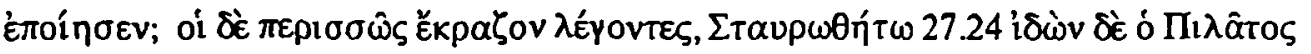

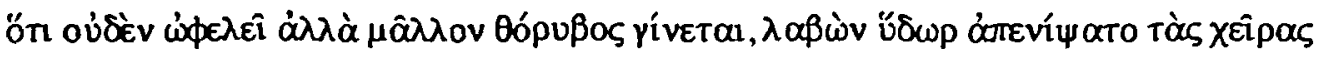

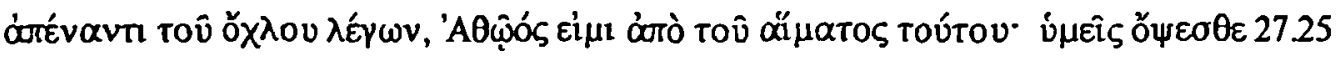

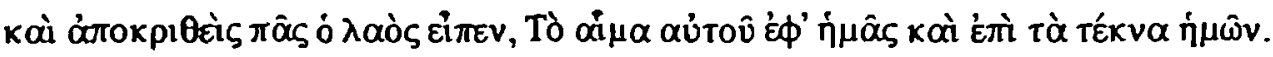

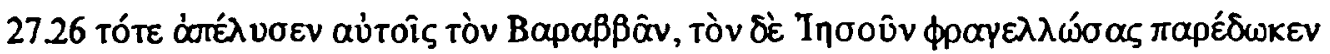

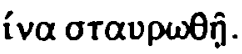

\section{The Context of Matthew's References to Pilate}

It has often been recognized that Matthew's gospel consists of five sections, or 'books'. Each contains a narrative followed by a discourse, eg the Sermon on the Mount (chapters 5-7), the discourse on mission (chapter 10), parables (chapter 13), the discourse on church life and order (chapter 18) and the eschatological discourse (chapters 24-25). This five-fold structure has frequently been compared to the five books of Moses making up the Torah, suggesting that Matthew regarded the Christian gospel as a new Torah 1 . The infancy narratives constitute an overture to the gospel, in which the main themes are introduced, whilst the passion narrative forms its climax. Many of the nativity themes are taken up again and reach their culmination in the final three chapters of the gospel ${ }^{2}$. For Matthew the death and resurrection of

\footnotetext{
${ }^{1}$ Such five-fold divisions were not necessarily limited to the Jewish Torah, for example the Psalms and Irenaeus' Adversus Haereses were similarly arranged in five sections. See Meier, 'Matthew', p 629.

${ }^{2}$ For example Herod's killing of the infants forms the earliest omen of the crucifixion; the same verb óró $\lambda \lambda \cup \mu \mathrm{u}$ (to destroy) is used at both 2:13 and 27:1 (and 12:14). The title Christ is also prominent in both sections - 1:1,16,18,2:4 and 27:17, 22 - as are dreams. See Vögtle, Matthäische Kindheitsgeschichte, pp 172fr.
} 
Jesus together constitute an apocalyptic event in which all prophecy is fulfilled. Israel has rejected its messiah and so the kingdom is given to another nation $(8: 11,21: 43)$ and the age of the church is established (28:1620). It is in this final dramatic fulfilment of prophecy that Pilate plays his role.

\section{Matthew's Sources}

The majority of scholars assume that Matthew's primary source was the gospel of Mark. Into this account Matthew has added sayings material (either written or oral) from at least one other source, Q, which he has in common with Luke, and an amount of material peculiar to his own gospel, including proof texts and legendary sounding stories, known as $M$ (though it is doubtful that this was a coherent single source) ${ }^{1}$.

Although he reorders and abbreviates Mark's material, Matthew generally follows his main source fairly closely ${ }^{2}$. In his account of the Roman trial, however, Matthew has been much freer with Mark's account than usual ${ }^{3}$. He has inserted the story of Judas' suicide between the account of the Sanhedrin's leading Jesus away and his standing before Pilate (27:3-10); he has also added the story of Pilate's wife's dream (27:19), Pilate's washing his hands (27:24) and the cry of the Jewish crowd (27:25) 4 . The rest of the Markan narrative has also undergone a considerable amount of redaction. This chapter will first look at special Matthean concerns within the passion narrative, as indicated by his redaction of Mark, before going on to look at the characterization of Pilate within the trial scenes.

\section{Matthew's Special Interests Reflected in his Redaction of Mk 15:1- 15.}

The themes prominent in Mark's presentation of the passion narrative the antagonism of the Jewish leaders, fulfilment of prophecy, kingship, mockery and rejection - have all been taken over and reused by Matthew in

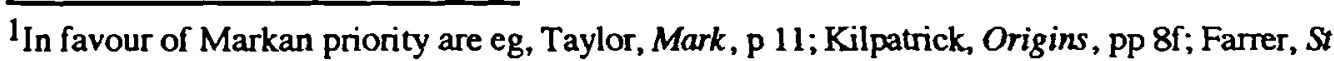
Matthew; Luz, Matthew, pp 73ff. For those who favour Matthean priority see Luz, Matthew, $\mathrm{p} 47$. There is however excessive disagreement amongst scholars regarding the $Q$ hypothesis. ${ }^{2}$ For discussion see Luz, Matthew, pp 46ff.

${ }^{3}$ Schweizer, Good News, p 506.

${ }^{4}$ For similar legendary sounding Matthean additions to the passion account see 26:52-54, 27:51-54, 62-66, 28:2-4; Kilpatrick, Origins, p 49.

$5_{\text {For a fuller account of Matthew's redaction of Mark see Senior, Passion, }}$
} 
his own account ${ }^{1}$. But he has skilfully blended the Markan text with other material to highlight his own particular concerns within the narrative.

a) A striking theme in Matthew's presentation of the Roman trial is that of the responsibility for the death of Jesus. Running throughout the whole scene is the haunting question: On whom did the guilt ultimately lie? Each actor, as he realizes what he has done, attempts to shift the responsibility away from himself. Judas, in 27:3-5, repented when he saw that Jesus had been condemned and vainly attempted to disassociate himself from what was to happen by returning the money to the chief priests and elders. Yet the betrayer could not so easily avoid God's judgement for his share of the guilt surrounding Jesus' death, as his own suicide shows (27:5). Similarly Pilate is warned by his wife not to have anything to do with Jesus ('that righteous man') and, later in the trial, will wash his hands to show symbolically that he will not accept responsibility for Jesus' death (v:24). Although Pilate refuses to acknowledge his guilt he, like Judas, cannot wash his actions entirely away. Primary responsibility for the execution of God's son, however, rests in the Matthean narrative with those who accept it - all the Jewish people (including the chief priests and elders): 'his blood be on us and on our children' (v:25). Using a traditional Israelite formula for indicating responsibility for a death in the eyes of God ${ }^{2}$, Matthew's whole Jewish nation willingly accepts the guilt for Jesus' death and, therefore, leave themselves open to the wrath which will inevitably fall upon them ${ }^{3}$.

\footnotetext{
${ }^{1}$ The events in Jesus' passion are seen as a fulfilment of all the prophets, 26:54, 56, this is perhaps why no specific OT quotations are used in the narrative. Only the death of Judas needs a special quotation to show that that too was in accordance with God's will, 27:9-10. This particular quotation seems to be a combination of Zech 11:12 (LXX) with Jer 18-19:13 (LXX). See Goulder, Midrash, pp 445-447, Moo, Tradition', pp 157-175. For a variant account of Judas' demise see Acts 1:18f; a fragment from Papias transmitted by Apollinarius of Laodocea (c AD 310-390) contains a gruesome and detailed account of Judas' demise, largely dependent on Luke's version.

${ }^{2}$ This expression is steeped with OT overtones in which blood coming upon the head of someone is a common formula as an expression of guilt, eg Jos 2:19, 2Sam 1:16, Lev 20:9, Dt 19:10, Ez 18:13. It is found as an expression of collective guilt in Jer 26:15: 'you will bring innocent blood upon yourselves and upon this city and its inhabitants'; and also in Mt 23:35 where the scribes and Pharisees are accused of killing and crucifying prophets, wise men and scribes 'that upon you (pl) may come all the righteous blood shed on earth'. Particularly close is 2Sam 3:28-29 where David, after saying he and his kingdom are guiltess before God for the blood of Abner, says 'may it fall upon the head of Joab, and upon all his fathers' house; and may the house of Joab never be without one who has a discharge ...' The expression is not a curse but a standard expression to designate responsibility for a crime and its consequences. Although the words of the Jewish people are addressed to Pilate within the narrative, the OT use suggests that it is really God who is being addressed. Thus the Jewish nation expresses its culpability before God for the crucifixion of its Messiah. See Reventlow, 'Sein Blut', pp 316-321.

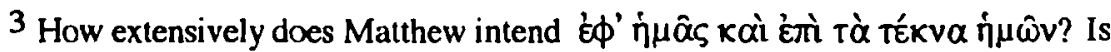
responsibility for the rejection and execution of the Messiah to rest on all subsequent
} 
b) Linked with this theme of responsibility and stemming from Matthew's own situation with regard to Judaism, is the much more anti-Jewish tone throughout his Roman trial scene compared to that of his source. Neither the Jewish leaders not their people are spared from Matthew's intense condemnation. In 27:1 the chief priests and elders of the nation meet together in order to kill Jesus ${ }^{1}$. The same group of people display a particularly callous lack of interest in justice in 27:4, and incite the crowd to ask not only for the release of Barabbas, as in Mark, but also for the condemnation of Jesus in $v: 20$. In the second section referring to Pilate, Joseph of Arimathaea is not a member of the Sanhedrin (as in Mk 15:43) but is described simply as 'a disciple of Jesus' (27:57); clearly Matthew will not allow the man who buried Jesus to be an influential Jewish leader.

The Jewish people themselves are no less implicated in Jesus' death. The very fact that the elders are clearly described as the elders of the people emphasizes that they act as the representatives of the crowds throughout the narrative (Mark has simply 'elders'). Although Pilate fears a riot in v:24, the majority of the Roman trial in Matthew gives the appearance of being a much more restrained, formal gathering than that found in Mark. The gathering of the crowds is described in v:17 using the verb ouvó $\gamma \omega$; Matthew has used the same verb to describe assemblies of the Sanhedrin $(26: 3,57)$. The Jewish

generations, or literally only one? OT parallels do not shed much further light on this. Ex 34:7, for example, extends the standard formula to the fourth generation of descendants whilst David's speech in 2Sam 3:29 implies that the guilt for Abner's death will remain with the house of Joab for ever. Mt 27:25 is certainly much more restrained than these OT examples. Many scholars take these words literally, suggesting that Matthew puts the blame for the rejection of the Messiah on both the historical generation of Jesus' time and their sons and daughters. This, they argue, would take the date to approximately AD 70. The destruction of Jerusalem could then be seen as the fitting punishment for this rejection (So for example Albright and Mann, Matthew, p 345; Kilpatrick, Origins, p 47; France, Matthew, p 226; Brown, Death, $\mathrm{p} 837 \mathrm{ff}$ ). This view has certain attractions, particularly for post-World War II scholars, in that it limits Matthew's anti-Judaism by seeing the fall of Jerusalem as a decisive divine retribution for the rejection of Jesus. If this were the case then modern anti-Semitism based on this verse could be shown to be inappropriate: the Jewish nation have paid their price in $\mathrm{AD} 70$. Theological reflections upon the responsibility for the fall of Jerusalem were certainly an extremely important issue in late first century Jewish writings (as those of Josephus clearly show) but does Matthew here really want to say that the Jewish people got their just deserts in the fall of Jerusalem, an assertion which would mean that the Jews of his own day are no longer responsible for the death of the Messiah? The anti-Jewishness of not only the trial narratives but the rest of Matthew's gospel suggests that it was written at a time of bitter dispute, even hostility, between Jewish Christians and Jews who refused to accept

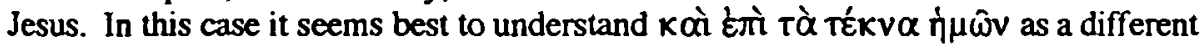
historical period of responsibility: that is, Matthew shows that the Jews of Jesus' time have rejected Jesus as the Messiah but so too do their 'children', the Jews contemporary with Matthew. In this way, the importance of this statement rests on the continuation of responsibility for Jesus' death with those Jews who still reject him in Matthew's day (see Przybylski, 'Setting', p 200). For further discussion see Dunn, Partings, pp 154-156.

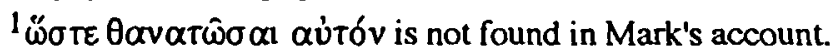


people have calmly come together to judge between Jesus and Barabbas. In $v: 20$, the chief priests and elders of the people persuade the crowds to ask for the release of Barabbas and the death of Jesus. Gundry asserts that Matthew's

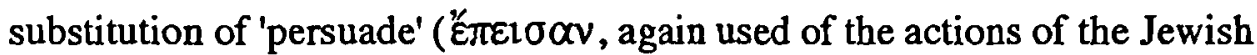
leaders in 28:14) 'lightens the crowd's burden of guilt by making them victims of evil persuasion'1. If anything, however, the reverse is the case. Mark's use of the verb 'to stir up' implies that the people are agitated almost to a state of diminished responsibility; Matthew's lighter verb gives the impression of a more reasoned decision, the crowd will make their request in the full knowledge of what they are doing. In response to Pilate's alternatives, the crowd ask for Barabbas. In Mark, the demand of the crowd is lost; we are to assume from the stirring of the crowds in v:11 and Pilate's question in v:12 that the crowd actually has demanded the release of Barabbas. Matthew, however, leaves us in no doubt. The governor puts the decision before the people and they calmly give their choice. The reaction of the crowd in Mark seems quite tumultuous, their cry otaúpwoov aủróv sounds like the clamour of a mob. Matthew, however, alters this. In his account the crowds say ( $\lambda$ Éyouoıv) what they want Pilate to do with Jesus: the verdict is clear and

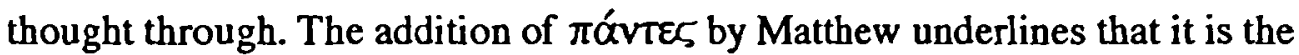
calculated choice of all the Jews, both the leaders and the crowds. Finally in

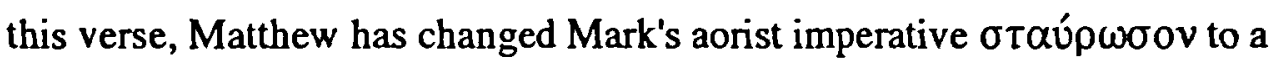
passive imperative $\sigma \tau \alpha u \rho \omega \theta$ ń $\tau \omega$, giving the impression that the Jews themselves are passing judgement.

c) Another striking element in Matthew's account when compared to that of his source is the emphasis on the choice between Jesus and Barabbas and the contrast between the two men. In place of Mark's one-sided 'Do you want me to release to you the King of the Jews?' Matthew has made the choice explicit: 'Whom do you want me to release for you, Jesus Barabbas or Jesus who is called Christ?' and again in v:21 Pilate asks 'Which of the two...' The parallelism is heightened by the fact that the two men have the same first name, Jesus ${ }^{2}$, and Barabbas' patronym would also be quite appropriate as a description of Jesus of Nazareth.

\footnotetext{
${ }^{1}$ Gundry, Matthew, p 562.
}

${ }^{2}$ Textual support for the reading Inooûv in verses 16 and 22 is not good; it is omitted by $*$ $A, B, D, L, W, \Delta$ and most others. Origen, however, in the third century remarked that many copies did not state that Barabbas was also called Jesus; Origen felt that the omission was probably right since no sinner in the whole of scripture bore the same name as Jesus (In Matthaeum CXXII). In the light of this reverential attitude, it is more likely that the name Jesus was erased from copies of Matthew than that it was added at a later date and so the 
Mark's description of Barabbas has been drastically reworked by Matthew. In particular his political activity - his possible involvement in an uprising and murder ${ }^{1}$ - has been suppressed by Matthew in favour of a much

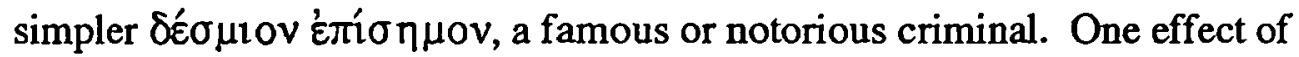
this contraction is that it does not detract the reader's attention from the theme of choice in the narrative. Another effect is that Barabbas' activity has been completely depoliticized, all hint of insurrectionary activity has been removed. Similarly Pilate refers to Jesus not as the politically loaded 'King of the Jews' but as 'Messiah'. The choice in Matthew therefore is no longer between two politically dubious men but one between a notorious criminal and the Christ; that is, it is the religious significance of Jesus which is at stake. If the crowd in Mark had some justification for their choice of a man tarred with possible political activity, the Matthean crowd have no such excuse. The emphasis is not so much on the man they choose (simply a notorious criminal) but the one they reject: their Messiah.

d) Throughout the entirety of this terrible scene, Matthew has underlined the innocence of Jesus ${ }^{2}$. The description of the fate of Judas shows that even Jesus' betrayer recognized this innocence. Verses 19 and 20 provide a dramatic break in the dialogue, almost as if each prisoner has been mustering his forces, adding suspense to the narrative. What is important here is that whilst the chief priests and elders side with Barabbas, God himself intervenes on behalf of Jesus, declaring that he is a righteous man ${ }^{3}$. Dreams are used frequently in Matthew and are an unquestionable source of divine guidance 4 . The choice of the people is therefore even more incomprehensible in Matthew's presentation: they calmly pass the death penalty on one whom God has declared innocent and who was in reality their Messiah. In so doing they have convicted themselves. The Roman trial in Matthew is not so much the

reading 'Jesus Barabbas' has been retained in brackets by the UBS Greek NT ${ }^{4}$ with a 'C' rating.

${ }^{1}$ See the chapter on Pilate in Mark for a fuller discussion of Barabbas' activity.

2The cvangclist has also cmphasized Jesus' foreknowledge and control of events: he adds a fourth passion prediction to Mark's three (26:1-2) and it is Jesus' prophetic words which set events in motion - it is only after he has spoken that his enemies meet to plot his death (Meier, 'Matthew', p 635).

${ }^{3}$ The idea of two sides, one of God, the other belonging to humankind, has previously appeared at another critical point in the narrative (16:23) where by not accepting the suffering of the Christ, Peter shows himself to be on the side of humanity opposed to God.

${ }^{4}$ God's word is communicated through dreams at 1:20f, 2:12,13 and 19f; dreams are also one of Yahweh's means of communicating with humans in the OT. See Everts, Dreams', p 231. Dreams are also found in other Graeco-Roman literature, eg Valerius Maximus 1.7.2 and Dio Cassius 44.17.1 (the dream of Julius Caesar's wife). 
trial of Jesus, or even Pilate, but the case against Judaism. Both the Jewish people and their leadership have rejected their messiah and declare themselves fully prepared to accept the consequences.

\section{The Characterization of Pilate in Matthew}

Matthew's presentation of Pilate is largely based on that of Mark's, though his own particular concerns at times give a slightly different slant to the way in which the Roman governor is portrayed. Although this is Matthew's description of the Roman trial, it is quite clear that it is not the Roman governor who actually takes centre stage: the evangelist is much more concerned to underline the Jewish nation's rejection of its Messiah and its ready acceptance of the ensuing guilt. To a large extent, the Matthean Pilate has become only a minor character when compared to Mark's presentation (despite the fact that the Roman trial is twice as long in this gospel), suggesting once again that for Matthew's community relations with Judaism were much more important and urgent than relations with Rome.

In 27:2 Pilate is identified not only by his name (as in Mark) but also by a rather vague description of his title: the governor ( $\tau \hat{\varphi} \dot{\eta} \gamma \varepsilon \mu o ́ v r) 1$. After a dramatic pause in which the suicide of Judas is narrated (27:3-10), we again return to the Roman trial as Jesus stands bound $(v: 2)$ before the governor (v:11) ${ }^{2}$. As in Mark's narrative, the Roman prefect begins by tackling the central political charge: 'Are you the King of the Jews?'. The Matthean Jesus

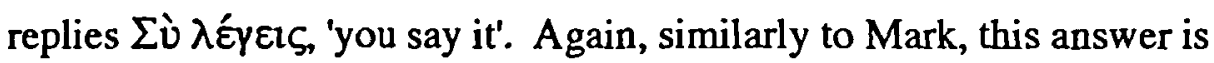
probably to be understood ambiguously - Jesus does not deny his kingship but nor does he accept the political title as an adequate description of his identity ${ }^{3}$.

\footnotetext{
${ }^{1}$ Pilate's precise title appears to have been praefectus; for the evidence see chapter 1.

${ }^{2}$ Although this is stereotyped legal terminology for a prisoner facing judgement (so Senior, Passion, p 225), possibly more than physical posture is implied here - Jesus is much greater than his Roman judge (Buck, Anti-Judaic, p 175). For binding following the condemnation of a prisoner see the chapter on Pilate in Mark.

${ }^{3}$ Several scholars who understand these words in an ambiguous sense in Mark have suggested that this reply should be taken as an affirmative in Matthew (eg Trilling, Gospel, p 487; Moffat, who translates 'Certainly'; Hill, Gospel, p 350; Fenton, Saint Matthew, p 433).

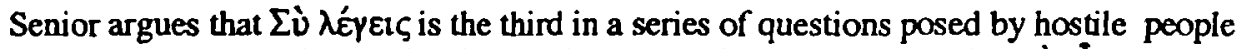
(Judas 26:25 and the High Priest in 26:64; to both of which Jesus replies $\sigma \dot{v}$ ei $\pi \alpha$ ) in which Jesus' reply is ironic, meaning 'You have answered your own question' ( $p$ 228). Yet if Matthew did want to understand Jesus' reply as an unqualified affirmative, it is odd that he has retained Mark's subsequent reference to the accusations of the chief priests (and elders) in $v: 12$ when an admission by Jesus to the charge of claiming to be the King of the Jews would have rendered other Jewish charges superfluous. Nor is it entirely certain that Jesus' answer to Judas in 26:25 would be understood as an affirmative since none of the other disciples attempt to stop him. Perhaps it is best to draw a distinction between the way in which the readers of the text would understand these replies and the way in which the characters within the text understand them. Thus in 26:25, the reader knows from 26:14-16 that Judas is the betrayer
} 
Matthew stresses both Jesus' silence and Pilate's amazement ${ }^{1}$. Unlike Mark, whose use of $\theta \alpha v \mu \alpha \zeta \zeta \omega$ did not seem to imply any kind of religious wonder, Matthew's use of it may do so to some extent. Astonishment is the standard reaction of the Matthean crowds to Jesus' words and actions ${ }^{2}$. This particular verb is used four times to express a sense of religious awe or amazement by Jesus' audience at a miraculous work. So, for example, after the storm in 8:27 the disciples marvel saying, 'What sort of man is this that even winds and sea obey him?'; and in 21:20 Matthew has added the amazement of the disciples to Mark's description of the withering of the fig tree (Mk 11:20f) ${ }^{3}$. Matthew's use of $\theta \alpha v \mu \alpha \zeta \omega$, then, may suggest a sense of religious wonder but, like the Pharisees and Herodians of 22:22 it may not be enough to persuade Pilate to abandon the interrogation of Jesus 4 .

and so understands the full force of Jesus' reply to Judas which has been dramatically added to the Markan account (cf Mk 14:17-21); the actors within the story, however, do not. Similariy in $26: 64$, the reader has had ample confirmation throughout the Matthean narrative that Jesus is the Christ, the Son of God, and understands Jesus' reply as an affirmative; the High Priest and other members of the council, however, do not realize that Jesus is the messiah of Jewish expectation. So too in the narrative under discussion, the reader knows that Jesus is in a sense 'the King of the Jews', a title which Matthew uses as a gentile synonym for 'Christ' (cf the quest of the magi in 2:2), and understands Jesus' answer as a guarded acceptance of the title; the gentile Pilate and the Jewish leaders again do not understand and so the trial continues. The irony involved in Matthew's use of these two levels of interpretation is obvious: like the High Priest earlier, Pilate has unwittingly stumbled on the truth of who Jesus is, though he cannot understand it himself (Howell, Matthew's, p 241).

Jesus is only referred to as 'King of the Jews' in Matthew by Gentiles - by the magi in 2:2, by Plate in this scene, the title on the cross in 27:37 and by the soldiers in 27:29; the title is redefined as 'King of Israel' by the mocking chief priests, elders and scribes at the cross (27:42). The title King is used by Jesus apparently of himself (as the Son of Man) in the parable of the sheep and the goats, 25:31-46. Matthew traces Jesus' descent through Judah's kings back to David in 1:6 and this Davidic line is repeatedly stressed throughout the gospel $1: 1,9: 27,12: 23,15: 22,20: 30 f, 21: 9,25: 31-46$. Kingsbury has shown that those who have correctly perceived Jesus as the Son of David in this gospel are those of no social or theological importance, eg blind men or the Canaanite woman ('Son of David', pp 598-601). Furthermore, any political understanding of this role is reinterpreted by the entry into Jerusalem where Jesus is addressed as 'the humble king', 21:5.

IThe Markan text implies that Jesus made no answer to the chief priests but Matthew makes

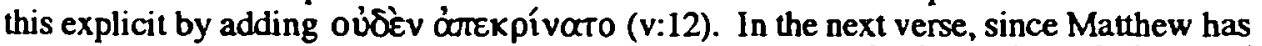
already stated that Jesus made no answer, he alters Mark's oủk ógokpívฤ oủdév to Oủk

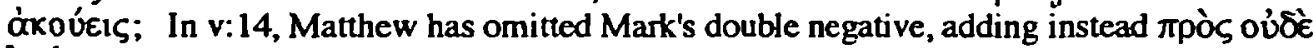
غे $\nu$ pं $\mu \alpha$ which stresses both Jesus' silence and the many accusations of the Jewish leaders. pंn̂ $\mu \alpha$ is probably to be translated as 'accusation' rather than its literal meaning 'word' (cf 18:16). This verse omits Jesus' name, focusing attention on Pilate's reaction. The evangelist has heightened Pilate's amazement by the addition of $\lambda i ́ \alpha v$.

${ }^{2}$ Eg. 7:28, 8:8, 9:33, 12:23 etc.

3 The verb is used seven times throughout the gospel in total, 8:10,27, 9:33, 15:31, 21:20, $22: 22$ and $27: 14$. Only two uses do not have religious overtones $-8: 10$ records Jesus' marvelling at the centurion's faith and 22:22 describes the Jewish leaders' amazement at Jesus' answer on tribute (a non-religious use and, incidentally, the only use of $\theta \alpha u \mu \alpha ́ \zeta \omega$ besides 27:14 taken from Mark). Other uses of the term with religious connotations are 9:33 where the crowds marvel Never was anything like this seen in Israel'; and 15:31 where Matthew

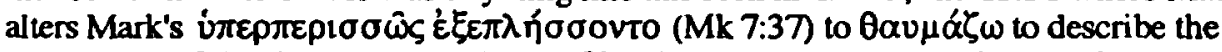
amazement of the throng at Jesus' acts of healing, acts reminiscent of Is 35:5f.

${ }^{4}$ The Pharisees continue their attack in 22:34-46. 
With v:15 the reader is informed of a custom of the governor, presumably established by himself or his predecessors, in which the crowd were allowed to obtain the release of any one prisoner whom they chose. V:16 similarly supplies background detail, explaining that Barabbas was also in custody at that time ${ }^{1}$, and in v:17 the crowds gather to await their annual privilege.

Throughout Matthew's gospel the Jewish crowds have generally been portrayed as friendly or neutrally disposed towards Jesus. They generally hold him to be a prophet $(21: 11,21: 46)$, even the Son of David (12:23, 21:9, $15)^{2}$, but are far from fully understanding Jesus' identity as the Christ, still less in terms of Matthew's central Christological title, Son of God ${ }^{3}$. Often they are shown as needing leadership or instruction or as being misled; they are generally only rejected in Matthew's presentation when they follow their traditional Jewish leaders ${ }^{4}$. The fate of the Jewish crowds then is not yet determined. They have formally gathered to choose between Jesus and the choice of their leaders, Barabbas. Theoretically it is still not too late to reject the candidate of their leaders and side with Jesus, though the reader has had some presentiment of what will happen by Jesus' four-fold prediction of his passion.

Slightly curiously after the apparently unlimited choice as to which prisoner should be freed in v:15, Pilate restricts the choice of the crowd in v: 17 to two men: Jesus Barabbas or Jesus who is called Christ. The depoliticizing of this choice has already been noted: Barabbas is no longer described as one with insurrectionary associations whilst Jesus is offered to the Jewish crowd not as the King of the Jews but by a title with profound religious connotations - Messiah. The charge has reverted to that which was uppermost in the Jewish trial $(26: 63,68)$.

Despite the gentile governor's perceptive equation of 'King of the Jews' with 'Christ', there is no sense in which the Matthean Pilate is trying to release

\footnotetext{
${ }^{1}$ The subject of Eixov, though not stated, is surely the Romans rather than the Jewish authorities.

2Individual members of the crowds accept him as Son of David at 9.27 (two blind men), 15:22 (the Canaanite woman) and 20:30,31 (another two blind men).

${ }^{3}$ Matthew links the titles Son of David and Christ at 1:6, 20f, and 21:5-9. Whilst Davidic descent is clearly important for this evangelist, it is transcended by Jesus' identity as the Chnst, as Jesus' debate with the Pharisees underlines (22:41ff). The reader knows that the Christ is not only the Son of David but more importantly the Son of God (16:16), a fact which has been revealed only to the disciples and to the genule centunon after Jesus' crucifixion (27:54).

${ }^{4}$ Eg 11:20-24, 23:27-39, 26:47, 55, and 27:20-25.
} 
Jesus here by appealing to the religious sympathies of the crowd. In a province where religion and politics were so inextricably intertwined, a 'purely' religious leader could be just as much a threat to Roman stability as a political insurrectionary ${ }^{1}$. The role of Pilate and the Jewish authorities in the passion account parallels that of Herod $I$ in the infancy narrative. There the Jewish King received news of the birth of the King of the Jews from the gentile magi (2:2) and automatically substituted this with 'Christ' when he discussed the matter with the chief priests and scribes of the people (2:4). Yet whether the child is referred to as 'King of the Jews' or as 'Christ' does not alter Herod's alarm at his birth, nor his intention of having him killed (2:13, 16ff) ${ }^{2}$. The prophecy of 2:6 clearly shows that the Christ was expected to be a ruler of Israel and so even someone claiming the religious title could potentially pose a threat to the ruling authorities ${ }^{3}$.

Pilate's question therefore, as in Mark, is a challenge to the people and an attempt to gauge Jesus' popularity ${ }^{4}$. Yet unlike Mark, Matthew has little interest in the characterization or motivation of Pilate, either the historical governor or the portrayal of him within his own narrative. The psychology of Pilate pales into insignificance next to Matthew's overriding concern to present the Jewish people with a choice which will ultimately determine their own salvation: a criminal or the Christ? 5

\footnotetext{
${ }^{1}$ Eg the Samaritan messiah of Antiq 18.85-87 and Bar Kochba; it is debatable whether these or any other Jewish uprisings of the first or early second century could ever be 'purely' religious.

${ }^{2}$ The same verb óró $\lambda \lambda \cup \mu \imath$ is used of both Herod's intention to destroy the infant Jesus (2:13) and the advice of the Jewish leadership in 27:20.

${ }^{3}$ Whether the historical Roman governor would have been aware of such expectations, or even would have equated 'King of the Jews' with 'Christ', does not matter here. Historically, it is quite probable that a Roman governor would have acquainted himself with the religious expectations of the people he governed; the Matthean Pilate obviously does make these connections and the first readers of the gospel would presumably have found Matthew's portrayal credible.

${ }^{4}$ The explanatory note v: 18 echoes Mark - Pilate knew that the Jewish leaders had delivered Jesus up out of envy. As in the Markan source, far from convincing the Roman governor of Jesus' innocence, this knowledge would only strengthen Pilate's desire to find out exactly what kind of a following Jesus really did command. His question in v:17 is therefore, like Mk 15:9, an attempt to gauge Jesus' popularity.

${ }^{5}$ The tille 'Christ' is extremely important for Matthew; he is concerned not only with showing that Jesus is the Christ but also with illustrating in what way Jesus is the Christ. The title is initially equated with the Son of David (1:1) and the King of the Jews (2:1ff) where it is understood politically but is then not used again until chapter 11 where it is redefined in terms of one who heals and saves (11:2ff where Jesus cites Is 35:5-6 and 61:1). An important stage is reached at 16:16 when Peter acknowledges not only that Jesus is the Christ but that he is 'the son of the living God' (a phrase not found in Mark). It is only 'from this time' (16:21f) that Jesus begins to tell his disciples about his impending sufferings and death and that discipleship involves taking up crosses (16:24). Matthew's conception of Messiahship is to a large extent summed up at Jesus' entry into Jerusalem where he is referred to as a 'king' and yet as 'humble' (21:5). The Roman governor, however, understands nothing of this and, like Herod, is threatened by Jesus' messiahship. On Christ in Matthew see Nolan, Royal, especially pp 145-149 and Kingsbury, Matthew, pp 96-98.
} 
Verses 19 and 20 provide a dramatic break in the action at this point, adding suspense to the narrative ${ }^{1}$. The chief priests and elders in v:20 are clearly backing Barabbas: not only do they persuade the people to ask for their candidate but they also ask them to demand the destruction of Jesus ${ }^{2}$. In the previous verse, however, a lone voice has spoken out for Jesus, taking the surprising form of a gentile woman - Pilate's wife. She urges Pilate to thave

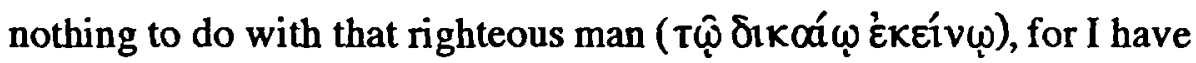
suffered much over him today in a dream ${ }^{3}$.

As noted above, dreams are an accepted method of divine communication in Matthew and other Graeco-Roman literature. One surprising aspect of this dream however is that in all other dreams in this gospel it is always the ones who are to make the important decisions who receive divine guidance through a dream. But in this particular case it is not the one in control, Pilate, who has the dream but his wife. Why should this be the case? Brown suggests that Matthew has used the prefect's wife in imitation of the frequent image of noble Roman pagan women favourable to Judaism found, for example, in the pages of Josephus ${ }^{4}$. This is probably correct but it does not fully explain why Pilate does not receive the dream directly. There may be three reasons for this. First, Matthew could not avoid the fact that Pilate did actually send Jesus to his execution: had Pilate received divine confirmation of Jesus' righteousness/innocence and still proceeded with the crucifixion, his guilt would have been just as great, or greater still, than that of the Jewish nation who had had no such divine proof. This would not have appealed to Matthew in his single minded attempt to pin as much responsibility as possible on 'all the people'. Second, the portrayal of Pilate

\footnotetext{
${ }^{1}$ The majority of translations give the word 'besides' for the Greek $\delta \dot{c}$ in this verse which Robinson, commenting on the Moffat texh, admits is 'perhaps, too strong an expression for the Greek connecting particle used here' (Gospel, p 227). It may be better to see this verse going not with vv:17-18 as an addition or expansion to Pilate's offer, or even a preparation for the hand-washing in v:24, but as forming a contrast with v:20 where the Jewish leaders persuade the crowd to ask for Barabbas (the NEB captures something of this sense when it translates the $\varnothing^{\prime}$ in v: 19 as 'while' and that in v:20 as 'meanwhile). In this case, Matthew is again highlighting the dramatic parallelism between the two men: the intercessor on behalf of Jesus, Pilate's wife, is guided by God whilst those who will shout against Jesus, the Jewish people, are led by men.

2In Mark the chief priests stir up the people to ask only for Barabbas' release; it is the people themselves who come to the conclusion that Jesus 'the King of the Jews' must be crucified $(15: 11,13)$.

${ }^{3}$ See 3:15 and the centurion's confession in $L k$ 23:47. Apocal yptic literature named Pilate's wife as Claudia Procla or Procula; she has also, with not much likelihood, been identified as a granddaughter of Augustus. She was canonized in the orthodox church. For further information see Fascher, Weib: Rosadi, Trial, pp 215-217.
}

${ }^{4}$ Brown, Death, p 806. 
familiar to the evangelist from Mark's gospel (and possibly Philo's Legatio ad Gaium and other negative oral Jewish appraisals) would not have suggested the governor as a likely recipient of a divine communication. Third, Matthew clearly and dramatically states that Pilate was on the judgement seat

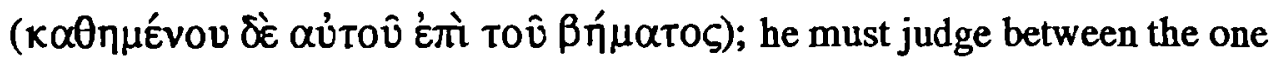
whom God has declared righteous and the criminal favoured first by the Jewish authorities and then by the people. Pilate is still neutral and the decision still hangs in the balance as he reiterates the question: Which of the two do you want me to release for you?'.

The people calmly give their choice: Barabbas. In answer to Pilate's next question: 'What shall I do with Jesus who is called Christ?' it comes as no surprise to the reader after v:20 that the people pass their solemn judgement: 'Let him be crucified'. The dramatic tension which characterized the Markan account has disappeared: as soon as the Jewish people accept the candidate of their leaders, their desire for Jesus' death follows inevitably. Jesus' only hope of acquittal lies with Pilate who, as he sits in judgement, has already heard a divinely inspired witness to Jesus' righteousness. But the Matthean Pilate is not willing to jeopardize his own position for Jesus. As a messianic claimant Jesus is a threat to his own rule and stability in the province and might be better disposed of. Having established that the Jewish people are more interested in having Barabbas released than Jesus, Pilate continues to probe them about Jesus. The Matthean Pilate seems undecided at this point: a messiah with no popular support could hardly undermine the authority of Rome or the Jewish aristocracy which worked so closely with the governor. He continues his line of questioning, 'Why what evil has he done?' only to be met with the same solemn judgement: 'Let him be crucified'.

At this point a riot appears to be about to break out and Pilate quickly determines on his course of action: whatever Jesus' guilt he will allow the people to have their own way and have him executed. But before they do so the Matthean Pilate makes sure that no reprisals can fall upon his head and stresses that it is the crowd themselves who have condemned their messiah.

In v:24 he uses a Jewish ritual of hand-washing to symbolize that it is the Jewish crowd who have demanded the death of Jesus: they are responsible and not he ${ }^{1}$. Pilate's words also reflect OT imagery, in particular 2Sam 3:28 and Ps 26:6 'I wash my hands in innocence ... '. This passage and

\footnotetext{
1 For evidence of handwashing as a means of protective purification in the Graeco-Roman world, see Brown, Death, p 834. The necessity and ritual of handwashing is described in Dt 21:1-9. This, however, applies to a situation in which an unsolved murder leaves the question of guilt; it has nothing to do with a judge passing sentence on a living man and wishing to shift responsibility onto others.
} 
27:4, which also focuses on the question of guilt for Jesus' death, are the only occurrences of the adjective 'innocent' in the NT. But whilst Judas in 27:4 uses 'innocent' to describe Jesus, Pilate uses the adjective to describe himself. This is significant: Pilate is not proclaiming Jesus' innocence (though the textual variant adds this), but affirming that he is not responsible for the guilt attached to Jesus' execution. Matthew's Pilate, then, is disassociating himself from this guilt by behaving in the manner of a pious Jew; the ritual in Dt 21:1-9 which absolves the people of Israel from the murder of the victim has been turned about to reflect the innocence of a gentile governor. Far from exonerating Pilate, the Matthean additions of the handwashing and his wife's dream involve him in a greater measure of guilt ${ }^{1}$. The Roman has failed to recognize a divine communication; in his attempt to avoid a riot he sends the man God has declared righteous to his execution and by means of a symbolic gesture refuses to acknowledge what he has done.

Pilate continues his address to the crowd, 'See to it yourself', (ívei $\zeta$ o้ $\varepsilon \sigma \theta \varepsilon$ ). This has striking parallels with $27: 4$ where the chief priests and elders tell Judas to 'See to it yourself', and is part of the Matthean theme of one actor vainly attempting to shift responsibility onto another. In v:25 the Jewish people rise to this challenge: if Pilate will not accept responsibility, they will, and they reply 'his blood be on us and on our children'. Once the Jewish people have fully accepted this responsibility and its implications, Pilate sends Jesus to be crucified.

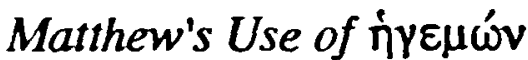

Before moving on from Pilate's characterization, one further point needs some consideration: Matthew's use throughout this scene of the title

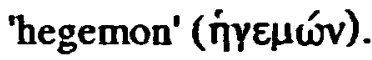

Whilst Mark refers to Pilate throughout this scene only by his

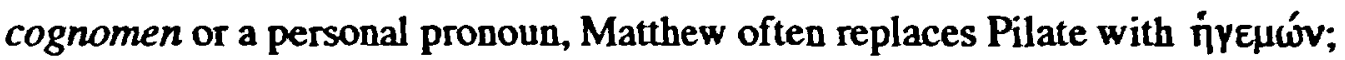
a term meaning 'governor' and loosely used of any Roman in control (eg 1Pet 2:14, Lk 2:2). The name $\Pi \lambda \lambda$ ôto h has been retained five times by Matthew (corresponding to Mark's first, third, fifth and eighth usage of the name, ie Mk 15:1 3,9,15, and the washing of hands, Mt 27:24) whilst the designation íreuóv is used of him six times (replacing Mark's second and fourth usage, ie Mk 15:2,4, supplementing Mk 15:1 and Mark's indefinite statement in 15:6 and two other statements without Markan parallels, Mt 27:11a and 21). The

\footnotetext{
'Bammel makes the same pornt, Traal', pp 447.
} 
two terms appear to have been used entirely randomly throughout the narrative.

How are we to account for Matthew's usage of these two designations for the Roman prefect? Most obvious is the suggestion that he is using the two terms for literary effect, to provide variation within the narrative.

Matthew has heightened the sense of conversation within the Roman trial and for reasons of clarity needs to keep reiterating who the speaker is. Rather than writing $\Pi \imath \lambda \hat{\alpha}$ To $\zeta$ every time the prefect needs to be referred to, as Mark

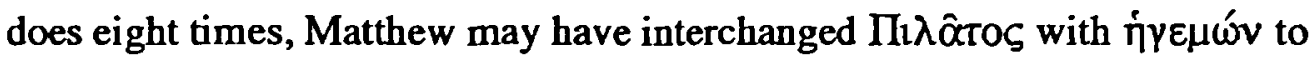
relieve the monotony. A second effect of using this title is that it emphasizes the official side of the hearing 1 .

These are plausible solutions for Matthew's use of $i \gamma \varepsilon \mu \omega ́ v$ and may well represent part of his motives at this point. However, there are several

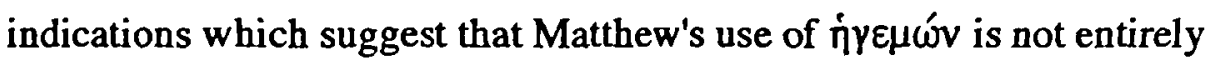
literary at this point. First, neither Jesus nor the 'chief priests and elders of the people' are ever referred to in any other way, although admittedly they are referred to far less frequently within this particular narrative than Pilate. But the fourth group within the dialogue, of ó $\chi \lambda$ or, do change their name and the alteration appears to be significant. The crowds' appear first in v:15, then v:20 and 24; in v:25, however, they have become $\pi \hat{\alpha} \varsigma \dot{o} \lambda \alpha{ }_{\alpha} \varsigma$. The majority of commentators understand this to mean that in v:25 Matthew wants to show the whole nation of Israel, the chosen people of God, joining together to accept guilt for Jesus' death ${ }^{2}$. Senior takes this even further, suggesting that Matthew's use of $\lambda \alpha o$ ć at this point shows that he understands the Jewish rejection of the Messiah as a 'pivotal event in salvation history'3. But there is also a sense in which the $\lambda \alpha$ ós of 27:25 who rejected the messiahship of Jesus before Pilate are also the Jewish nation of Matthew's own day who continue to deny that Jesus is the Christ ${ }^{4}$. Thus the use of $\lambda \alpha o^{\prime} \zeta$ in connection with the rejection of Jesus would also have a contemporary significance for Matthew's audience.

Secondly, v: 11 a is Matthean, repeating v: 2 and setting the scene for the Roman trial after the description of Judas' suicide in vv:3-10: 'Jesus stood

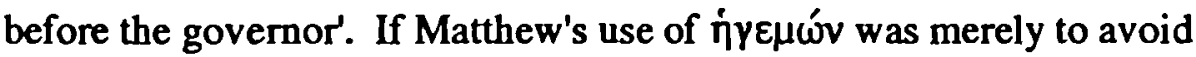
repetitious use of $\Pi_{\imath} \lambda \hat{\alpha}$ Tos, it would be reasonable to expect the designation

\footnotetext{
'Senior, Passion, p 225; though of course Pilate's historical title was 'prefect'.

${ }^{2}$ See for example Fenton, Saint Matthew, p 436; Gundry, Matthew, p 565; Beare, Gospel, p 531.

${ }^{3}$ Senior, Passion, p 258.

4Przybylski, 'Setting', p 200.
} 
'Pilate' here since he has not been mentioned for the last eight verses. Yet Matthew's Roman trial opens with Jesus standing before a ì $\gamma \mu \omega v^{\prime}$ and it is only in v:13 that the governor is named. This suggests that Matthew's interest is not so much in the historical prefect of Judaea who sent Jesus to crucifixion but in his identity as a Roman governor, such as many in his own community may be forced to stand before.

This suggestion is supported by an earlier passage in the gospel, 10:1623, a section which clearly intends to strengthen Christian disciples of Matthew's own day who are suffering persecution from both Jews and Gentiles ${ }^{1}$ :

Beware of men; for they will deliver you up to councils, and flog you in their synagogues, and you will be dragged before governors and kings for my sake, to bear testimony before them and the Gentiles (vv: 17-18).

Clearly there can be a positive consequence to Jewish rejection in that trials before governors and kings afford an opportunity for the Christian community to preach their message to the gentiles. Although Matthew does not use the trial before Pilate in this way ${ }^{2}$ - the evangelist is too taken up with the momentous events in salvation history and the apportionment of guilt - he may well intend Jesus to act as an example to later Christians ${ }^{3}$. Jesus does not need to protest his innocence (God does that for him in v:19 through Pilate's wife); instead he is calm and silent in the face of hostile forces so that even the $\dot{\eta} \gamma \varepsilon \mu \omega ́ v$ was amazed at his demeanour. Matthew shows his readers that if they maintain the same quiet trust in the face of persecution they will be told what to say and their testimony will be heard by the gentiles ${ }^{4}$.

Pilate therefore, though playing his role in an important historical event, also functions to some extent as the type of Roman governor before whom Matthew's community may be forced to bear their testimony.

\footnotetext{
${ }^{1}$ See Hare, Theme, who concludes that Jewish opposition to Christianity was not systematic, violent or sustained but took the form rather of spontaneous mob actions. Segal, Matthew's', suggests that some Jews regarded Christians as dangerous heretics and reported them to the authorities, p 4.

${ }^{2}$ Against Gundry, Commentary, pp $559 f$.

${ }^{3}$ Brown notes that what happens to Jesus foreshadows the future fate of his disciples, Death, $p$ 735 .

${ }^{4}$ Whether this envisages missionary work outside Palestine see McNeile, Gospel, p 140.
} 
The Matthean Pilate plays a much less significant role within the Roman trial scene than the Markan Pilate. His characterization is secondary to Matthew's major concern to show the entire Jewish nation rejecting their messiah and their acceptance of responsibility.

To a large extent this can be seen as a development from Mark's account. There Pilate skilfully manipulated the crowd by his challenging use of 'King of the Jews' into shouting for Jesus' crucifixion. The Roman prefect could then send Jesus to his execution knowing that the people had acquiesced to it (even demanded it) and that reprisals could not fall upon his own head. Similar themes are at work in Matthew's presentation but with one important alteration: the Jewish crowd no longer require a manipulative Roman governor to influence them. All hints of political pressure have been removed, both from Pilate's questions regarding Jesus and Matthew's description of Barabbas. The Jewish people are simply asked to choose between their messiah and another prisoner; this they do, calmly asking for Barabbas and passing the death sentence on their messiah. As in the Markan source, the people demand crucifixion and take responsibility for it, but this motif has been significantly highlighted by Matthew and all hints of external pressure from Pilate have been removed, giving at times a rather colourless picture of the governor.

Yet the Matthean prefect cannot escape his share of the guilt. He attempts to show his innocence by publicly washing his hands and telling the Jewish nation to see to Jesus' execution themselves. Yet, like the chief priests in 27:4 who say the same words to Judas, Pilate is already too deeply implicated and cannot abdicate his responsibilities. Again this can be seen as a development of the Markan Pilate who engineered the situation so that he was not directly to blame for the death sentence and so could avoid reprisals. The Matthean Pilate publicly proclaims his own innocence and when the Jewish nation accepts responsibility, sends Jesus to his death. Pilate and the Jewish authorities, together constituting the rulers of Judaea, mirror Herod I in the infancy narrative; all these leaders feel threatened by the messiahship of Jesus and wish to have him eliminated.

On a secondary level, Pilate as iं $\gamma \varepsilon \mu \omega ́ v$ together with the whole Roman trial symbolize what Matthew's readers are being forced to go through themselves as a result of Jewish hostilities against them. 
Finally, it is clear that Matthew's chief concern is with the breakdown of relations between his own community and the synagogue. Primary guilt for the death of Jesus, according to Matthew, lies with the Jewish authorities and the nation, but Pilate, symbolizing Rome, is not entirely exonerated. This would fit in well with a community which found itself facing the growing intrusion of Pharisaic authority in its region, particularly in Galilee and CoeleSyria where the emerging Rabbinic movement was centred ${ }^{1}$. This location might also fit in well with Matthew's portrayal of Pilate; whilst not so harsh and calculating as in Mark, the Matthean Pilate is nonetheless indifferent towards Jesus and willing to let the Jewish authorities have their way as long as he does not have to take responsibility. This would tie in with Rome's gradually emerging acceptance of the court decisions in religious law of the sages at Yavneh, an acceptance which could be threatening to the Christian communities there ${ }^{2}$. It would not be surprising if their attitude towards Rome was uncertain, one in which governors could be menacing or indifferent, and Roman leaders were led in their decisions by Jewish authorities.

\footnotetext{
${ }^{1}$ Schulrer, History, vol I (rev), pp 525ff; Safrai, CRINT, pp 406ff; White, 'Crisis', pp 238-242; Segal, 'Jewish', p 36.

${ }^{2}$ Evidence for an official act on the part of the Roman administration authorizing the revival of jurisdiction by the Jewish courts is not strong. However, the sages at Yavneh did in effect begin to take on the role of the Jerusalem Sanhedrin as the supreme law-court of Israel; a role which was at least tolerated by Rome. A tradition recorded in pSanh 1:2.19b (also pSanh $1: 4.19 \mathrm{C}$ and d) refers to certain questions put to R. Johanan b. Zakkai (the first leader of Yavneh, c 70s - 80s) by an unnamed hegemon'; whoever this governor might have been, the 'tradition may be best viewed in the context of others concerning R. Johanan's contacts with the Roman authorities with a view to their sanctioning the foundation of the school at Yavneh, as indicating that $R$. Johanan's concerns included matters of civil law' (Jackson, 'Roman Influence', p 162). Several rabbinic texts relating to the mid to late 90 s when Gamaliel II took over the leadership suggest a certain amount of interaction between the sages and Rome - see Safrai, CRINT, pp 406 ff for references. See also Saldarini, Pharisees, who regards the Pharisees as a client group of Rome; Clark-Wire, 'Gender', p 111.
} 


\section{CHAPTER 6}

\section{Pilate in Luke-Acts}

From the Jewish Christian world of Matthew we move to the much more Gentile outlook of the two-volume work known as Luke-Acts.

Although written for predominantly Gentile Christians, the Jewish atmosphere which pervades the gospel suggests that the recipients of Luke's work did not convert from paganism but were already sympathetic towards the synagogue, possibly God-fearers, before their conversion to Christianity ${ }^{1}$. Luke's interest in table-fellowship and the Law indicates that his audience also included Jewish Christians ${ }^{2}$. Like the other gospel writers, Luke probably had a specific community in mind ${ }^{3}$. Exactly where this community was located is unknown; perhaps the most that can be said with certainty is that it was in a large city of the Roman Empire ${ }^{4}$. Although various cities have been suggested - for example Caesarea ${ }^{5}$, Rome $^{6}$ or Philippi - tradition associates Luke-Acts with Antioch ${ }^{7}$. This would make good sense of the emphasis in Acts on that city (chapters 11-13); and, if the numerous references to Roman officials and soldiers throughout Luke-Acts reflects Luke's own community ${ }^{8}$, the headquarters of the Syrian legate would be a likely place to find such people?.

\footnotetext{
${ }^{1}$ See Esler, Community, p 25.

${ }^{2}$ Esler, Community, pp 31-45; Maddox, Purpose, pp 31-56.

${ }^{3}$ Esler, Community, p 26, commenting on Luke's use of 'ittle flock' in Lk 12:32 suggests 'that they were members of a small Christian community beset by difficulties from within and without'; also Acts 20:17-35. Other scholars, however, eg Johnson, 'Luke-Acts', assume Luke has a much larger readership in mind, $\mathrm{p} 405$.

${ }^{4}$ Luke often adds the word mó $\lambda 1 s$ to his Markan source; the focus of his teaching is nearly always in cities and his immersion in Hellenistic culture also probably indicates an urban setung; see Cadbury, Making, pp 245-249; Esler, Community, p 29.

5 Suggested by Klein, Zur Frage', pp 467-477.

${ }^{6}$ Conzelmann, 'Luke's Place', suggested that the author grew up in the Aegean region but actually wrote his two works in Rome, p 302; Rome is also favoured by Creed, Gospel, p lvi.

${ }^{7}$ Eusebius $H E$ 3.4.6, 24; Jerome De viris illustribus vii; and the Anti-Marcionite prologue which states that the gospel was written for Gentiles in the districts around Achaea. The second century Gnostic Basilides and Marcion's teacher, Cerdo, both were Antiochenes and both used only Luke's gospel (Leaney, Commentary, p 4, citing Bacon). The Western text of Acts 11:28, if not original, is an early second century testimony to Luke's relationship with Antioch (Ellis, Gospel, p 54).

${ }^{8}$ Esler, Community, p 210.

${ }^{9}$ Scholars favouring Antioch include Ellis, Gospel, p 54; Strobel, 'Lukas', pp 131-134; Fitzmyer, Gospel, p 53; Esler, Community, p 231 n.36; Evans, Luke, p 15.
} 
The dating of Luke-Acts is similarly uncertain. Arguing that Luke does not know the outcome of Paul's trial in Rome, several scholars suggest that the whole two-volume work is to be dated to the early 60s ${ }^{1}$. Probably the majority of commentators today, however, assume that Luke used Mark in the composition of his gospel and that Lk 21:20-24 refers to the fall of Jerusalem, both of which would indicate a later date. Since Luke does not seem to know of any of Paul's letters (some of which were collected and circulated $c$ AD 952), and since he says in Lk 1:1 that many had written before him, Luke-Acts is probably to be dated sometime in the $\mathrm{AD} 80 \mathrm{~s}^{3}$.

\section{The Contexts of Luke's References to Pilate}

Pontius Pilate is referred to five times in Luke's gospel. Three of these occur before the trial, 3:1-2a, 13:1 and 20:20c. The Roman trial occupies 23:1-25, and Pilate is briefly referred to again in 23:52 when Joseph of Arimathaea asks for Jesus' dead body. The governor is mentioned in Acts at 3:13, 4:27 and 13:28 (all in connection with Jesus' execution). The text for the trial narrative is as follows:

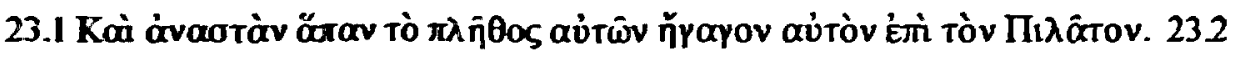

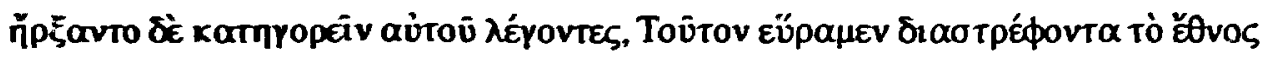

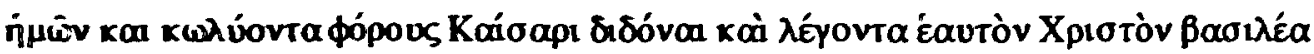

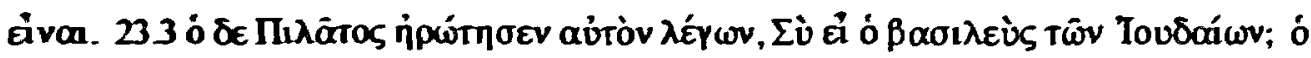

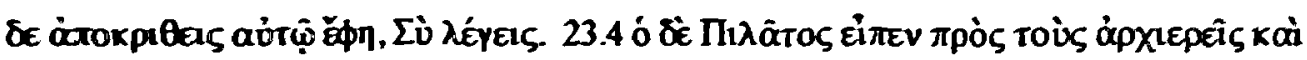

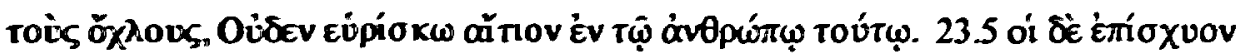

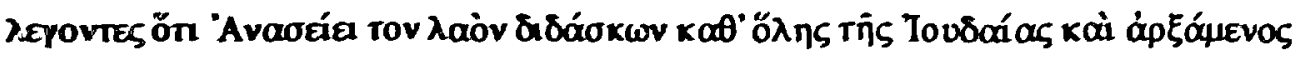

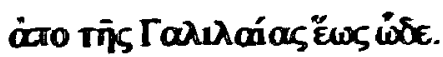

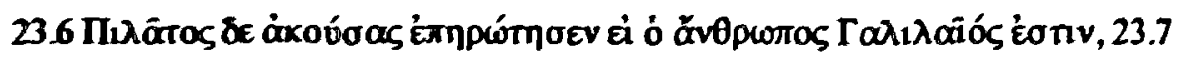

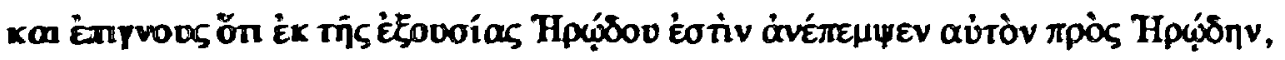

\footnotetext{
IEg Rotumson, Redaring, Moms, Luke, p 26.

2Finegan, Ongunal Form", pp 85-103.

3M Larsthall sugeasts nou long afier AD 70, Luke, p 35, as does Ellis, Luke, pp 55-58. Fitzmyer purts at stogthity laver at 80-85, Gospel, pp 53-57; Creed, Gospel, at 80-90, p Ivi; Esler Commoury, p 29) suggests mid tate 80s to carly $90 \mathrm{~s}$. An exceptuonally late date was argued by OWeall, Theology chapter 1, who dated Luke-Acts to 115-130.

Tradituon aconbes the wning of Luke-Acts to Luke the physictan, a companion of Paml referred to um Col 4:14, 2Tim 4:11 and Pulem 24-Irenacus Adv. Haer 11. 1 and the AnthAlamoune prologe. Cadbury, Sryke, however, has shown that Luke may have had no more

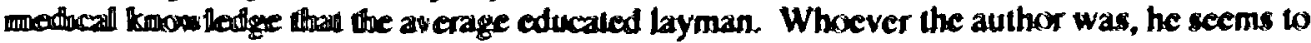

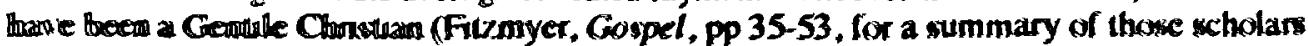

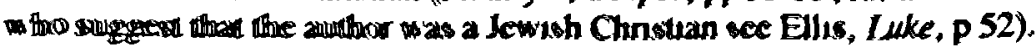




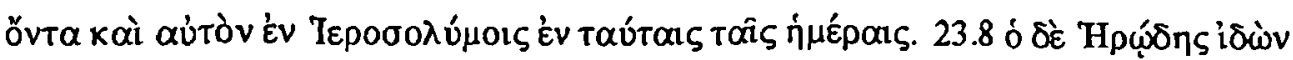

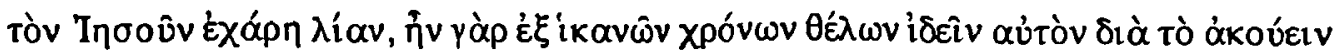

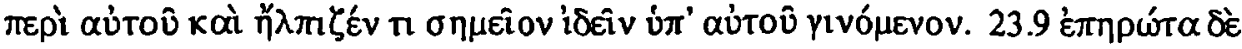

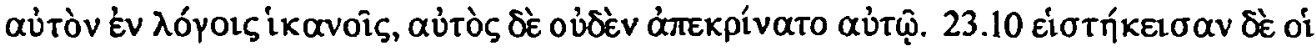

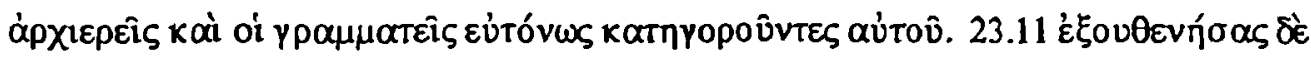

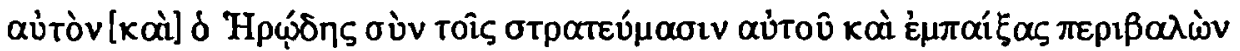

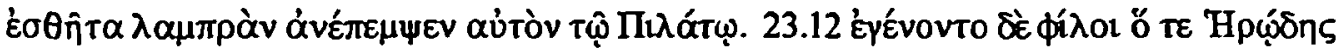

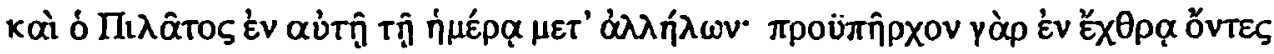
$\pi p o ̀ s \alpha u ̛ \operatorname{tov́s.~}$

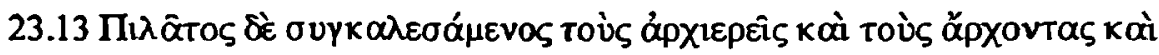

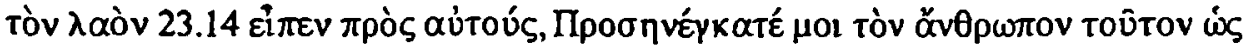

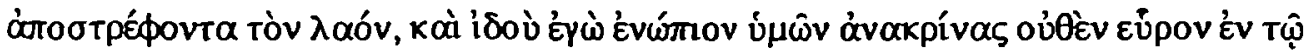

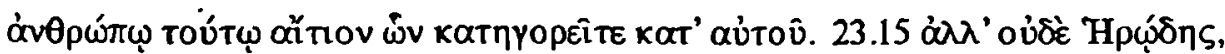

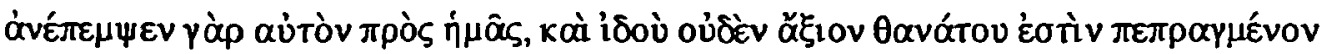

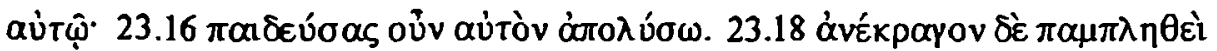

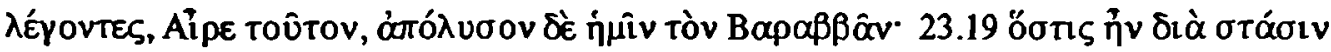

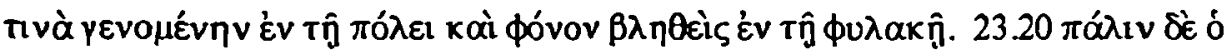

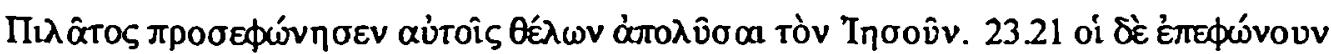

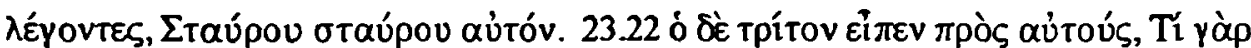

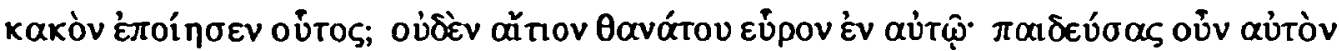

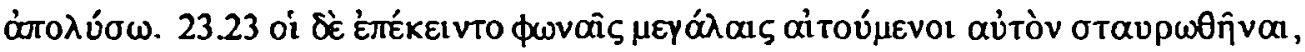

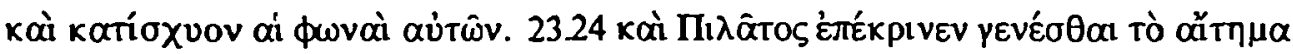

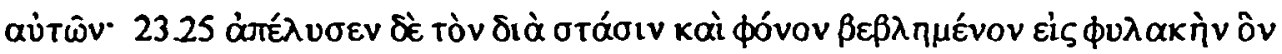

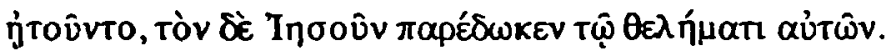

This chapter will briefly look at Luke's sources and major themes within the passion narrative before turning to consider the characterization of Pilate within Luke's gospel. Finally it should be possible to see how this portrayal of the governor fits in with the references to him throughout Acts.

\section{Sources Used by Luke in the Composition of his Passion Narrative}

As already indicated, the majority of scholars assume that Luke relied heavily upon Mark in the composition of his gospel. Into this he has added material common to Matthew (often referred to as a single written source, Q) and his own traditions, which may have come down to him in either written or oral form, or both (often referred to as L). Although he generally follows 
Mark closely ${ }^{1}$, within the passion account Luke moves away from this source, often to a considerable degree, leading several scholars to speculate as to whether he is following a new source at this point ${ }^{2}$. The results of recent studies on this question by scholars such as Soards and Matera, however, have shown that there is no evidence that Luke made use of another written passion narrative; the additions and alterations which he makes to Mark can all be explained by his use of $\mathrm{L}$ material and his own particular theological motives ${ }^{3}$.

\section{Lukan Themes Influencing his Portrayal of Pilate}

1) Throughout his gospel and Acts, Luke shows a marked tendency to link significant Christian events with imperial history. For example, Jesus' birth at Bethlehem came about because of a decree of Caesar Augustus, a decree which was followed unquestioningly by Joseph (Lk 2:1-7). In this way, Luke has shown the politics of Rome working hand in hand with God's divine purpose for salvation; as Walaskay observes, the pax Augusta was completed and complemented by the pax Christi ${ }^{4}$. Similarly in Acts, Agabus' prophecy of the world famine, which Luke tells us was fulfilled in the time of Claudius, is the impetus for sending Paul and Barnabas to Jerusalem with relief aid (11:28); Claudius' expulsion of the Jews from Rome allows Paul to meet and stay with Priscilla and Aquila in Corinth (18:2), whilst the decision of Gallio, the proconsul of Achaia, allows Paul to continue his work in Corinth 'many days longer' (18:12-16). For Luke, the decrees of Roman emperors and governors and events during their reigns have allowed Christianity to flourish ${ }^{5}$. This strongly suggests that Luke's community were particularly interested in the relationship between Christianity and the Roman Empire.

This is borne out further by the fact that in Luke's gospel the Jewish trial has the air of a preliminary hearing (22:66-71) whilst the Roman proceedings are much longer and form the only real trial of Jesus 6 : in this

\footnotetext{
I Johnson, 'Luke-Acts', p 406.

${ }^{2}$ Eg. Taylor, Passion Narrative; Sloyan, Jesus; Bailey, Traditions; Marshall, Gospel, p 852; Grundmann, Evangelium, p 421.

${ }^{3}$ See Soards, Passion, which concentrates on chapter 22; and especially Matera, Luke 22, $66-$ 71', and 'Luke 23, 1-15'. This view is also held by Fitzmyer - for a full discussion see Gospel, pp 1365ff; also Evans, Luke, p 859; Creed, Gospel, p Ixiii.

${ }^{4}$ Walaskay, And So, p 26. Also Esler, Community, pp 201-202.

5 Walaskay, And So, p 26; Esler, Community, pp 201-202.

${ }^{6}$ Whilst Mark devotes only 15 verses to the hearing before Pilate, Luke devotes 20 verses to it (and 5 to the hearing before Herod which, coming in the middle of the Roman trial (23:8-12), gives the impression that Jesus is in Roman hands even longer. Conversely, Mark's Jewish
} 
gospel the Jewish court does not reach a verdict, nor is Jesus bound as a condemned man before he meets Pilate; the only official verdict is that passed by the Roman prefect in 23:24. How Jesus fared in a Roman court was obviously of great significance for Luke's audience.

2) Linked to Luke's interest in the position of Christianity vis-à-vis Rome is his positive evaluation of the majority of Roman administrative or military personnel with whom the early Christians came into contact. Even those who were not converted are described favourably, for example the centurion of $\mathrm{Lk}$ 7:1-10 1 , Julius in Acts 27:3 or the centurion of 27:42-43. Quite a number of them do accept Christianity, for example the soldiers of Lk 3:14, Cornelius in Acts 10:1-11:18 and Sergius Paulus in Acts 13:6-12. Luke repeatedly emphasizes that the hero of Acts, Paul, is himself a Roman citizen (16:37-40, 22:24-29, 25:10-12).

There is, however, one group of Roman officials in Luke-Acts who do not receive such positive descriptions: these are the governors before whom Christians are put on trial. Whilst they may serve an invaluable role in publicly declaring the political innocence of Christianity before Rome (so Pilate and Festus) or enabling the spread of the gospel (so Gallio and Festus), their characters are questionable in the extreme. Although Gallio's ruling is beneficial for Paul and the spread of his message, the governor dismisses the case against him without even a preliminary hearing and completely ignores a public disturbance involving Sosthenes, the ruler of the synagogue, right in front of his tribunal (Acts 18:12-17). The overriding impression of Gallio is that he does not want to get involved with anything. In Acts 24 Felix allows Paul to speak in his own defence against his Jewish accusers but shows a reluctance to come to any decision, putting the case off in v:22 until Lysias arrived. In fact, the case is put off for two years ( $v: 27$ ), during which Felix is said to have visited Paul often. His motive for doing this, however, is not an interest in what Paul has to say but, according to Luke in v:26, because he hoped that Paul would offer him a bribe in return for his release. At no time does he give an opinion as to Paul's guilt and seems totally disinterested in justice. When he is succeeded by Porcius Festus, he leaves Paul in prison; Luke points out that this is not because he thought Paul was guilty but because

trial occupies 12 verses (Mk 14:53, 55-65) whilst Luke's is narrated in only 6 verses. In effect, Luke presents his audience with one trial comprising of four scenes which is why there is no Jewish condemnation in 22:66-71; see Matera, 'Lk 23:1-25', p 551.

${ }^{1}$ Even if the centurion is historically unlikely to have been a Roman citizen, he still upholds Roman interests in the province and it is as such an upholder of the Roman regime that Luke portrays him (cf Sherwin-While, Roman, p 124 and Walaskay, And So, p 33). 
he wanted to do the Jews a favour (v:27). The suggestion that the actions of the Roman governors were prompted by the wish to do the Jews a favour is extended to Festus in 25:9 who instead of trying Paul in Caesarea suggests that he stand trial in Jerusalem. Paul says that the governor knows that he has done no wrong against the Jews (v:10) and seems to be accusing Festus of giving him up to them (v:11); in the interests of justice, Paul's only hope is to appeal to Caesar (v:11) ${ }^{1}$.

In Luke-Acts therefore there is always a distinction between these governors as the representatives of Roman law, (which finds Jesus and his followers innocent of any political crime), and their weak self-seeking characters (which occasionally hinder the proper implementation of that law when the Jewish authorities have had a hand in the proceedings ${ }^{2}$ ). It will not be surprising, therefore, if Pilate similarly conforms to this pattern.

3) Luke's attitude towards the Jewish nation at times seems quite ambiguous $^{3}$. He is consistent in showing the Jewish leadership as antagonistic towards Jesus and plotting his death (eg 5:17, 21, 6:7). The crowds, on the other hand, respond positively towards Jesus to the extent that they hinder the attempts of their leaders to do away with him (eg 19:47-48, 20:19, 21:38, $22: 2,6,53)$. During the trial before Pilate, however, a dramatic change takes place in the people. Having been summoned by the governor in 23:13 along with their chief priests and rulers, they spontaneously cry for crucifixion 4 . Although he does not hide the fact that Pilate gave his verdict on the case, Luke clearly shows that this is in accordance with Jewish wishes: 'So Pilate gave sentence that their demand should be granted' ( $v: 24)$. Luke's presentation gives the impression that it is the Jewish nation itself which crucifies its Messiah5; this is also emphasized in Acts 2:22-23, 3:12-13, 4:27 and 13:27-296.

\footnotetext{
${ }^{1}$ See also the magistrates of Acts 16:35-39.

${ }^{2}$ Esler, Community, makes a similar point, pp 203-205; Walaskay, And So, pp 23-24. Acts records no instance of Roman intervention without previous Jewish agitation; see Conzelmann, Theology, p 140.

${ }^{3}$ This ambiguity has led to various interpretations; at one extreme Sanders regards the whole of Luke-Acts as anti-Semitic, Jews; whilst others, eg Johnson, 'Luke-Acts', pp 414f, claim that Luke deliberately diminishes the role of the Jewish people in the death of Jesus.

${ }^{4}$ The urgency of the crowd's demand has been intensified by Luke: Mark's aorist imperative $\sum \tau \alpha u ́ p \omega \sigma o v$ aủtóv (v:13) has been converted to a more emotional present imperative and

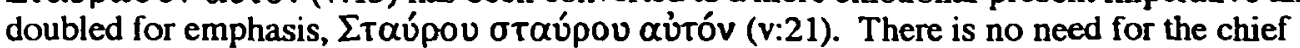
priests to stir up the crowd in Luke's presentation (as in Mk 15:11).

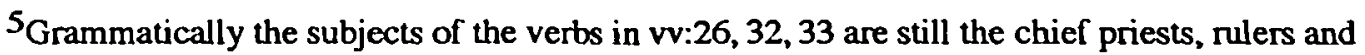
the people of $v: 13$. Assuming that the soldiers referred to in v:36 are Roman soldiers, the majority of commentators maintain that Luke cannot avoid the historical reality that Jesus died at Roman hands, but only wants to give the impression that he was executed by Jews, eg
} 
Yet later, at the cross, the Jewish leaders ridicule Jesus whilst the people first watch (23:35) and then return home beating their breasts (23:48). The spectacle has led them if not to repentance at least to remorse ${ }^{1}$. In 23:34 Jesus prays for their forgiveness as does Stephen in Acts 7:60; despite rejecting its messiah then, Israel has not been totally rejected in Luke's presentation.

Perhaps the reason for Luke's ambiguity in his description of the Jewish people and their sudden unexpected demand for Jesus' death before Pilate has been summed up by Evans:

'Luke emphasizes Jewish responsibility for Jesus' death, not because of anti-semitic hatred, but because of his desire to place the Messiah's death firmly within the framework of biblical (ie Israelite) history. Jesus' rejection and death are prophesied in the Scriptures and are in keeping with Israel's 'historic' (biblical) habit of persecuting the prophets 2 .

4) In connection with this portrayal of the Jewish people is Luke's presentation of Jesus as a rejected prophet ${ }^{3}$ and innocent martyr who goes unjustly to his death ${ }^{4}$. The theme of Jesus' innocence is given special prominence during the trial and crucifixion narrative: Pilate publicly declares Jesus innocent three times $(23: 4,14,22)$; Herod too is said to have found no crime in him (23:15); even one of the criminals crucified with Jesus corroborates Pilate's verdict (23:41); and a centurion standing by the cross utters 'the last word and true verdict of Jesus' life and death'5 - 'Certainly this man was innocent' (23:47). Luke shows his readers that even though Jesus'

Evans, Luke, p 859. Sanders, Jews, however, argues that the soldıers are Jewish and that Luke has consciously described a Jewish crucifixion; also Walaskay, Trial", p 92. In Luke, three of Jesus' four passion predictions give the impression that his death will be at Jew ish hands 9.22,44-45, 17:25). Only in 18-32-33 are Gentles mentioned and their role appears to be a passive one.

6In L 24:20 two of Jesus' Jewish disciples lay the blame with the chief pnesis and rulers whilst in 4:10, 5:30 and 7:52 members of the Jewish council are accused of causing Jesus' death themselves.

'Carroil, Luke's Cructixuon', p 111.

2 Evans, Luke's View', p 55.

${ }^{3}$ E\& 4 24; 7:16,39, 13:31-33, 23.27-31,24 19-20; Acts 3:22-23. For a fuller discussion sae Carroll, Luke"s Crucafixuon', pp 113-114.

${ }^{4}$ The equation of Luke's Jesus with a martyr has been customary since Dibelius, from Tradituon, p 201; sce Carroll, Luke's Crucifixion', pp 118-121; Talbert, Reading, pp 212f Rather than a mantyr, Green suggests that Luke presenis Jesus' death as the Iravanic servant (Death", pp 21-28), whilst Kams suggewts that Luke wanis to show Jesus as the innocenily suffenng nghtecus one ("Lk 23 4T, pp 77 78).

SCarroull, Lulke's Crucufixusin", p 118 
innocence was recognized by Roman and Herodian rulers, he unjustly went to his death because of Jewish machinations.

Luke took a bold step in underscoring Jesus' innocence and the plots of the Jewish leadership in 23:2 where instead of the unspecified accusations found in his Markan source ${ }^{1}$, he clearly describes the charges on which the Jewish hierarchy have brought Jesus before Pilate. If Pilate's declarations of Jesus' innocence are to have any value, they have to be made with respect to specific charges ${ }^{2}$. It is one general charge and two specific examples: Jesus is said to have distorted their nation, forbidden the payment of tribute to Caesar and claimed to be Christ a king ${ }^{3}$. All three accusations have been carefully prepared for by Luke in his preceding narrative; a portrayal which has shown the falsity of all three claims. The first and most general charge - that of perverting the nation - which, in the context seems to imply political incitement against Roman authority ${ }^{4}$, has been prepared for in 9:41 where Jesus describes the nation as already perverse, indicating that their perversity is not a result of Jesus' teaching5. The second accusation - Jesus' specific command not to pay tribute - has already been dealt with at 20:20-25. There the Jewish leaders attempted to force Jesus to take a stand on a politically delicate yet burning contemporary issue ${ }^{6}$ : should one pay tribute to the emperor or not? The question was a trap: if Jesus advocated the non-payment of tribute then he allied himself with those of a more nationalistic outlook who urged the resistance of payment and could be reported to Pilate; if, however,

\footnotetext{
1Mk 15:1-2; the reader must assume that claims to kingshup were an accusation, otherwise Pilate's question in v:2 makes litule sense; Mark, however, does not specifically say so.

${ }^{3}$ Sımılar charges will be levelled aganst Paul in Acts 17:6-7, 24:5-6,12, 25:8 and also aganst Jason and others in Acts 17:6ff.

${ }^{4}$ The verb $\delta$ aotpépw can be used in a religious sense meaning 'to turn away from the true fauth' as in $1 \mathrm{Kgs}$ 18:17f, Acts 13:8,10, 20:30. This is the sense in which Marcion interpreted

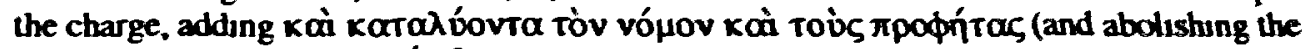
law and the prophets) after njürv (Epiphanius, Adv. Haer. 13.316,317,346). But in view of the two clearly politucal charges which follow, the apparenty synonymous use of the more

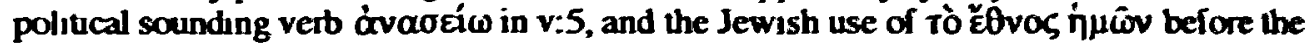
Roman governor to denote their 'nation' rather than their fauth or laws, it seems best to understand the charge in a political sense: Jesus is accused of inciling his fellow countrymen to sediuon; see Evans, Luke, p 845.

Sanders notes that simular charges were levelled aganst Moses by Pharaoh (Ex 5:4) and against Elijab by Ahab (1Kgs 18:17). In fact, Moses, Elijah and Jesus are carrying out God's will; it is only evil rulers who consider their activity sedituous (Jews, p 7).

SFor a contrary view see Cassidy, Jesus, p 65, who argues that the charge does carry some weight in that Jesus has freely criticized the existung orders of society and those supporting them and called for radically different social patterns.

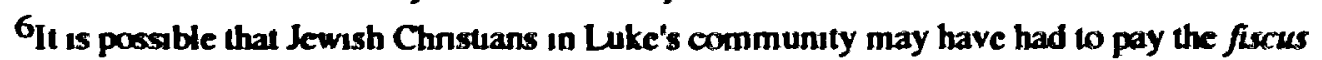
Judaicus introduced by Vespasian and payable by all Jews throughout the empire in addituon to the other provincial taxes.
} 
he too glibly urged the payment of the oppressive taxes, then he risked losing face with his supporters. Jesus' answer was clever: although allowing some ambiguity ${ }^{1}$, his reply set up two spheres, that of Caesar and that of God, in which each can make legitimate demands; paying taxes to Caesar was permissible as long as it did not interfere with one's duty to God ${ }^{2}$. The charge put by the Jewish authorities to Pilate is clearly a distortion of Jesus' answer at 20:25, as Luke's readers would quickly have realized. The third charge is more difficult. Although Luke's readers do believe that Jesus is the $\mathrm{Christ}^{3}$, a king of the Davidic line ${ }^{4}$, and at certain points in the preceding narrative he seems to accept this designation 5 , Jesus never actually called himself a king, certainly not in the political sense in which the Jewish leadership have presented the matter to Pilate. In Luke's presentation, Jesus' messiahship is expressed by his identity as teacher, prophet and martyr rather than kingship. The reader knows that the charge is a deliberate distortion of Jesus' messiahship in terms which would be almost sure to attract the interest of a Roman governor.

In contrast to the rulers in Mark then, the Lukan Jewish aristocracy clearly present their charges to Pilate; yet the reader knows that they are false distortions and realizes that Jesus is innocent of all their accusations.

An interesting feature of Luke's trial before Pilate is that except for the exchange in 23:2-3 the charge of kingship, a charge which was dominant in Mark and, we shall see later, in John, has been obliterated 6 . Although Luke's Pilate addresses the people three times as in the Markan source, the politically challenging questions, 'Do you want me to release for you the King of the Jews?' and 'Then what shall I do with the man whom you call the King of the Jews?' (Mk 15:9, 12) have been completely reworked, omitting the references to kingship. Instead, in Luke's presentation, the dominant charge is that of perverting the people which appears three times (23:2, 5 and 14). This gives the impression that Jesus stands trial because of his teaching rather than on account of politically dubious messianic claims.

\footnotetext{
${ }^{1}$ Pointed out by Cassidy, Jesus, p 58.

${ }^{2}$ This is the view held by the majority of commentators, eg Creed, Gospel, p 247; Evans, Luke, pp 708-709; Derrett, 'Luke's Perspective', pp 42-43.

$3_{2: 26,4: 41,9: 20}$

${ }^{4}$ Eg. 1:32-33, 2:4, 3:31, 18:37, Acts 17:7.

5 Jesus is hailed as 'the king (absent in Mark and Ps 118:26) who comes in the name of the Lord' at his entry into Jerusalem in 19:38 and does not reject the title. Later in the gospel, after the resurrection, the Lukan Jesus speaks of himself as Christ, 24:26, 46.

${ }^{6}$ The titles 'King of the Jews' and 'Christ' reappear at the crucifixion - 23:37, 38 and 23:35, 39.
} 
Conversely, Barabbas' insurrectionary activity has been highlighted. Whilst Mark does not specifically say that Barabbas was involved in the uprising and murder, only that he was in prison along with certain men involved in an otherwise unknown insurrection ${ }^{1}$, Luke puts all the blame for the revolt and murder on him. Furthermore, the insurrection is located in the city', right under the prefect's nose ( $v: 19$ ). The contrast between Barabbas and Jesus is starkly underlined in the final verse of the trial narrative: Pilate 'released the man who had been thrown into prison for insurrection and murder, whom they asked for; but Jesus he delivered up to their will' ( $v: 25$ ). The choice of the Jewish crowd, Luke shows, was not an innocent teacher and prophet but an insurrectionary and murderer, a political rebel against Rome ${ }^{2}$.

Their culpability is highlighted all the more by Luke's drastic reworking of the Barabbas scene. Whereas Mark begins his narrative by describing the so-called privilegium paschale and Barabbas, setting up the element of choice from the beginning, Luke has omitted any reference to the amnesty and only introduces Barabbas afier the crowd have demanded his release ${ }^{3}$. The effect of this is to focus the reader's attention on the relationships between Jesus, Pilate and the Jewish people. No choice has been given to the Jewish representatives and so their spontaneous cry for a political rebel rather than Jesus is all the more blameworthy. The Jewish demand for Barabbas here foreshadows the revolt of AD 66-70 and the terrible consequences prophesied to 'the daughters of Jerusalem' in 23:28-314.

5) Although Luke's community do not seem to be experiencing any form of systematic persecution themselves ${ }^{5}$, Jesus' martyrdom presents them with an example should their faith be put to the test. Acts shows Christian disciples who were called to suffer a similar fate to their master. Stephen and Paul (and, briefly, James in Acts 12:2). Acts 6:9-7:60 describes the trial of Stephen before a Jewish council and his subsequent death. A remarkable feature of this account is that many of the details associated with the Jewish trial of Jesus

\footnotetext{
1See the ctrapter on "Pilate in Mark".

2Thus is emphasized agan in Acts 3-14

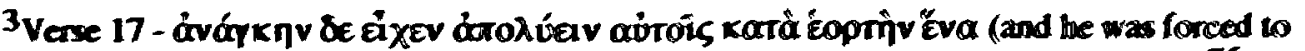
release cone man to them at the festus all) - is omued by many early wrinesench as $75, A$ and $B$; others bave thus, or a vanant form, either bere or af ier $v 19$. The evidence sugat the verse is a secondary gloss based on Mk 15.6 and $M i 27.15$ that the reference 10 Barabas in v: 18 is not so abrupt.

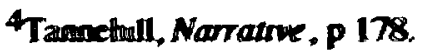

5Waladkay, And So, p 11: Sanders, Jews, p 23; aganna Comelmama, Luke's Place", p 301 . In companuon to the ouber gospels, references to endurance in the lace of trouble or bardstup in Luke are lew $-815,923-27,181-8 ; 2112$.
} 
in Mark and Matthew and omitted there by Luke have found a place here: the false witnesses (6:13, Mk 14:56); the accusation of speaking against the temple (6:13f, Mk 14:58); the charge of blasphemy (6:11, Mk 14:64); and the anger of the council (7:54, Mk 14:63f). Luke seems to have deliberately modelled Stephen's trial around material which in his source belonged to that of Jesus before the Jewish council. Even more striking are the parallels between Paul's trials and those of Jesus. Paul is also brought before a Jewish council (Acts 22:30-23:10), before the Roman governor Felix at which time accusations are brought by the Jewish high priest, elders and spokesmen (24:1-23); before Festus (25:6-12); and before the Herodian king Agrippa with Festus (25:23-26:32). In exactly the same way that Jesus' innocence was stressed by the Roman and Herodian rulers, so is Paul's lack of guilt: 23:29, $25: 25,26: 31,32$. Are these parallels simply coincidental, or has one set of trials been influenced by the other? The question has particular significance regarding Jesus' trial before Antipas (23:7-12). No other gospel even alludes to this trial ${ }^{1}$, the section contains a greater number of characteristically Lukan words than the rest of the passion narrative ${ }^{2}$ and the questions of judicial procedure which it raises are considerable. These features led Dibelius to conclude that this section is Lukan invention, based on Christian reflection on Ps 2:1-2, cited explicitly in Acts 4:26ff - 'for truly were gathered together ... both Herod and Pontius Pilate' $(v: 27)^{3}$. But the proceedings do not describe a conspiracy against the Lord's anointed and it is just as likely that Luke inserted the trial for some other reason and used Ps 2 to justify its inclusion 4 . The most convincing hypothesis regarding the trial before Antipas is that of Walaskay who suggests that Luke inserted a trial before a Herodian to parallel Paul's trial before Agrippa ${ }^{5}$. This suggestion has several features in its favour. For a start, Luke seems to have no information as to what went on during Jesus' trial before Herod; all the events are taken either from various other parts of the gospel or are discreditable elements from Mk 15:1-5 which Luke has omitted in his presentation of the trial before Pilate. Secondly, since

\footnotetext{
1The only other reference to it in the NT is at Acts 4:26rf; not even John, who has other points of sumlarity with Luke - Pilate's threefold declaration of Jesus' innocence, the playing down of the Barabbas episode and the implicauon that Jesus is delivered into Jewish hands for crucifixion - refers to this event. Luke seems particularly interested in Antipas, for statistics see Brown, Death, p 764.

2Hoehner, "Why Did", p 84; Brown, Death, p 761.

3Dibelius, 'Herodes', pp 131fr; followed by Burkill, 'Condemnation', pp 330r; Creed, Gospel, p 280, Losy, L'Evangile, pp 544-545.

4Fitrmyer describes the relation of this story to Ps 2:1-2 as 'tenuous indeed', Gospel, p 1179.

SWalaskay, And So, p 43; Trial', pp 88-89; followed by, amongst others, Matera, 'Lk 23,1-25', p 545.
} 
Paul's trial was more recent and perhaps therefore fresher in the memories of his community, Luke may have wanted to show that all the trials experienced by the great apostle to the gentiles had already been anticipated in the trials experienced by Jesus.

The trial before Antipas therefore is most probably a literary composition designed to parallel Jesus' trials with those of Paul; an analysis of the proceedings themselves and Pilate's motives for sending Jesus to Antipas therefore belongs not to the realm of historical enquiry but to the realm of Luke's literary art and how he wishes to portray Jesus in Roman/Herodian hands ${ }^{1}$.

\section{The Characterization of Pilate in Luke}

\section{A) References to Pilate before the Roman Trial}

In contrast to Mark's presentation, Luke's narrative refers to Pilate three times before the trial with the effect that his readers have already built up some picture of the prefect before he appears as Jesus' judge.

a) In the fifteenth year of the reign of Tiberius Caesar, when Pontius Pilate was governor of Judaea ...' (3:1).

Luke opens his account of the ministry of John the Baptist with a stylized dating typical of other ancient writers in which he firmly sets the beginnings of the Christian movement within imperial history 2 . The dating adds credibility to the narrative: the fixed and specific time references suggest that Luke will be accurate in what he has to relate (backing up his declared intention in the prologue, $1: 1-4)$. To a large extent all the rulers mentioned in 3:1-2a represent Roman interests, from the Herodian client kings to the Jewish high priest(s) appointed by the Judaean prefect ${ }^{3}$. Pilate takes his place next to Tiberius as the emperor's representative in the province, the governor of Judaea. The verse then gives us no information regarding Pilate's character

\footnotetext{
IIn the later Gospel of Peter responsibility for Jesus' death has shifted from Pilate to Herod, GPet 1:1-2:5.

${ }^{2}$ See Rienecker and Rodgers, Linguistic, vol 1, p 211 . Historically, this information is not as straightforward as it may at first appear; for various methods of dating see Hoehner, Herod, pp 307-312 (Appendix vii).

${ }^{3}$ For the appointment of the high priests (which during Jesus' ministry was the responsibility of the prefect of Judaea) and the division of Herod l's kingdom between his sons see chapter 1.
} 
but simply sets the scene, locating the drama on the imperial stage and linking Pilate closely with Tiberius.

b) 'Some people present at that time told him about the Galileans whose blood Pilate had mixed with their sacrifices' (13:1).

In its literary context, this event is used by the Lukan Jesus to show that the victims of Pilate's action (and, in v:4, the fall of the tower in Siloam) were no more sinful than the rest of his hearers:

Do you think that these Galileans were worse sinners than

all the other Galileans, because they suffered thus? I tell

you, No; but unless you repent you will all likewise perish. (13:3-4)

The aim of $13: 1$, then, is not primarily to give a description of an atrocity committed by Pilate but to use the event to counter the prevalent view that such victims died because of their sins. Jesus' reaction to the news is not to criticize Pilate but rather the views of his hearers and to call for repentance. Yet despite this, the incident does give the reader a further insight into the character of Luke's Pilate.

13:1 directly follows $12: 57-59$, a passage calling for reconciliation with opponents. The effect of this is to make Pilate's actions appear even more heavy-handed; the Roman governor has made no effort to settle with the Galileans, instead he has chosen a particularly cruel and bloody course of action.

But who are these Galileans within Luke's narrative? Are they simply Galilean pilgrims who have come to Jerusalem to offer their sacrifices, or are their purposes much more sinister? ${ }^{1}$ A comparison with the tower in Siloam which fell and accidentally killed eighteen people (v:4) suggests that both the Galileans and the Jerusalemites in Siloam are to be seen as innocent victims. Despite the occasional equation of Galilee with insurrectionary activity ${ }^{2}$, there is no indication in Luke-Acts that the author intends to describe anything more than their geographical origin (eg Lk 22:59, 23:6, Acts 1:11, 2:7, 5:37). Luke's 'Galileans' then seem to be simply pilgrims from Galilee ${ }^{3}$.

\footnotetext{
${ }^{1}$ Cullmann suggested that 'Galileans' should be interpreted as Galilean zealots in the line of Judas the Galilean and his sons; their sacrifices being not religious offerings but pro-Roman sympathizers whom they had killed, State, p 14. Vermes goes further when he asserts that 'those pilgrims whose blood Pontius Pilate mingled with their sacrifices must have been Galilean revolutionaries', Jesus, p 47.

2Talbert describes Galilee as 'a hotbed of revolutionary activity', Reading, p 216; for fuller discussions see Hengel, Zealots, pp 56-59; Vermes, Jesus, pp 42-57; Freyne, 'Bandits', however contrasts the relative peace in Galilee during Antipas' reign compared to the situation in Judaea, pp 53f.

${ }^{3}$ So also Fitzmyer, Gospel, p 1006; Marshall, Gospel, p 553.
} 
How does this verse affect our understanding of Pilate's character in Luke? First, his behaviour appears particularly aggressive, ruthless and insensitive; the pilgrims have come to Jerusalem to offer their sacrifices to Yahweh and Pilate has had them executed. Luke gives no reasons for Pilate's actions and the very fact that the Galileans have just been sacrificing suggests that they have done nothing wrong, implying the governor's violence was

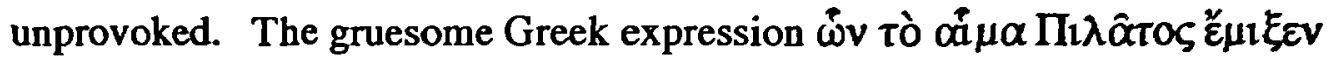
$\mu \varepsilon \tau \grave{\alpha} \tau \hat{\omega} v \theta v \sigma 1 \hat{\omega} v \alpha \hat{v} \tau \hat{\omega} v$ suggests a barbaric slaughtering in the same way that the sacrificial victims were killed ${ }^{1}$. Secondly, the reader has seen Pilate's brutal behaviour towards a small group of Galileans. Jesus, too, is a Galilean and this fact is underlined not only in the birth stories and throughout the gospel, but also at his trial before the Roman governor ${ }^{2}$. Will Pilate act so ruthlessly again?

In summary, this remark describes Pilate as a man indifferent to suffering and contemptuous of the religious susceptibilities of those over whom he governed. We are prepared to expect a cruel, ruthless man.

3) ... so that they might hand him over to the power and authority of the governor. (20:20c).

This verse forms an introduction to the controversy over the payment of tribute to Caesar (20:20-26). Luke's Markan source leaves the precise course of action determined upon by the Jewish leaders (there the Pharisees and Herodians) rather vague: they attempt only to 'entrap him in his talk' (Mk 12:13) and, in the light of his popularity described in 12:12, their principal aim could be to make him lose face with his supporters. Luke's account, however, plainly shows that the intention of the scribes and chief priests is to force Jesus to take a stand on a political issue which will then be used in evidence against him before the Roman governor.

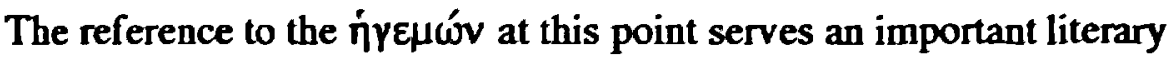

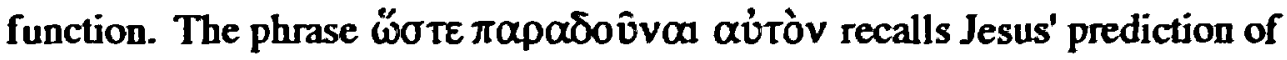
his passion in 18:32. In 20:20f the reader sees how this handing over to the Gentiles will take place and connects it with the question about the payment of tribute to Caesar. These themes will reappear in 23:1-2 where Jesus is brought before Pilate by the members of the Sanhedrin and charged with

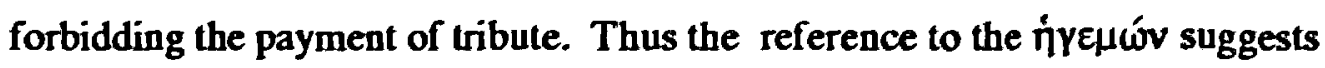

\footnotetext{
${ }^{1}$ See Derret, "Galleans', p 103; Winter, Trial, p 177 n.9.

${ }^{2}$ See especially $1: 26 ; 2: 4,39 ; 4: 14$; also the references in $23: 49$ and 55 to the women who have followed Jesus from the beginning show that they too are from Galilee; Brown, Death, p 763.
} 
that Luke wants the reader to recall this scene, including Jesus' answer, whilst he or she is reading the account of the Roman trial in 23:1-25.

\section{Summary of References to Pilate before the Roman Trial}

By the time the Sanhedrin hand Jesus over in 23:1, the reader has formed some picture of Pilate. He is the Roman governor of Judaea, representing imperial interests in that province. He has ruthlessly slaughtered some Galilean pilgrims for no apparent reason. The chief priests and scribes are plotting to hand Jesus over to him on a political charge. At the hands of such a man, Jesus' fate would seem extremely precarious.

\section{B) The Characterization of Pilate in the Roman Trial: $L k$ 23:1-25}

After their preliminary hearing, the members of the Jewish council bring their prisoner before Pilate in 23:1 and, acting as the official accusers required by Roman law 1 , they charge Jesus with perverting the nation, forbidding the payment of tribute and claiming to be Christ a king. The scene has therefore been set for a political trial; a Roman governor could not afford to allow a suspected political agitator to go free, particularly in a province as volatile and turbulent as Judaea. If Pilate accepts the allegations of the members of the Sanhedrin, then the execution of Jesus is assured.

By way of examination, Pilate picks up only on the third charge against Jesus asking, as in the other gospels, $\Sigma \dot{v} \varepsilon \hat{i} \delta \beta \alpha \sigma \imath \lambda \varepsilon \dot{\zeta} \varsigma \tau \hat{\omega} v$

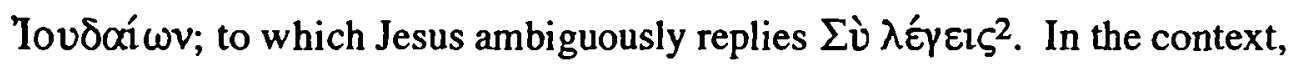
these words must be taken by Pilate as a denial, otherwise his following statement is incomprehensible ${ }^{3}$. Yet even so it is unexpected: Oúdìv

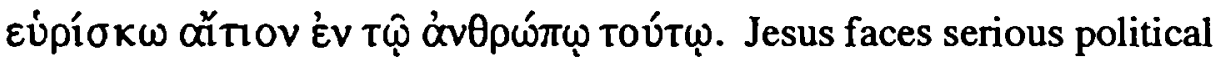
charges and yet Pilate has proclaimed him innocent without even trying him. The charges of subverting the nation and forbidding tax payment have not even been touched upon. As Walaskay puts it: 'With a case of treason, Pilate should have proceeded further with his case extra ordinem. A Roman court would not have been content with any other than its own investigation.' 4 Luke apparently wants his readers to understand that Pilate quickly saw Jesus'

\footnotetext{
${ }^{1}$ Evans, Luke, p 845.

${ }^{2}$ Both these phrases are from Mark, for a detailed discussion see 'Pilate in Mark'.

${ }^{3}$ Grundmann, Evangelium, p 422.

${ }^{4}$ Walaskay, Trial', p 85.
} 
innocence despite the Jewish accusations against him, that there was no point in trying him further. In Fitzmyer's words: 'the evangelist is interested only in the conclusion reached by Pilate'1. Yet at another level, it is an odd portrait of a Roman governor which emerges, one who appears to have dismissed such serious political accusations entirely out of hand and who is surprisingly unwilling to try the case properly ${ }^{2}$.

Again in v:5 the first charge of stirring up the people is repeated, this time with greater urgency. The precise identity of those speaking is ambiguous: either we are to assume that it is still the members of the Sanhedrin or, in the light of the preceding verse, that the multitude has also joined forces with the chief priests in accusing Jesus. This time the emphasis falls on Jesus' teaching, fitting in well with the frequent portrayal of Jesus as a teacher in Luke ${ }^{3}$. The vast extent of Jesus' teaching is also stressed. 'Judaea' is probably to be understood in its broadest meaning as the whole of Palestine since Luke seems to want it to incorporate Galilee 4 . The geographical framework of the gospel is underlined here: Jesus' teaching began in Galilee and has now reached "̌́ $\omega \varsigma \hat{\omega} \delta \varepsilon$, Jerusalem. The reference to Galilee may also strike an ominous note to any readers who remembered Pilate's brutal treatment of Galilean pilgrims in 13:1. A political agitator, then, who hailed from Galilee and who had brought his revolutionary teaching right up to Jerusalem could hardly be ignored by the representative of Roman rule. Surely now Pilate will have to try Jesus on a political charge.

Yet again, Pilate declines to take the case seriously. In v:6 he picks up the previous mention of Galilee and inquires whether Jesus is a Galilean. The question underlines the fact that Jesus is completely unknown to Pilate; if Jesus was any threat to the state whatsoever, the governor would surely have received reports about him already. Finding that Jesus belonged to Herod's jurisdiction, Pilate determines to send the prisoner to him in v:75. Luke gives no motives for Pilate's actions at this point ${ }^{6}$; the dominant impression is that

\footnotetext{
1 Gospel, p 1474.

2 Black notes 'Pilate shows an obvious reluctance to deal with the case', 'Arrest', p 23. ${ }^{3}$ Eg. 8:49, 9:37, 10:25, 12:13, 18:18, 19:39, 20:21,28,39, 21:7; Matera, 'Lk 23.1-25, pp 540541.

${ }^{4}$ Hoehner, 'Why Did', p 85, regards it as equivalent to the whole 'land of the Jews' (cf Acts 10:37, 39); also Goulder, Luke, p 757.

5The verb óvoré $\mu \pi \omega$ can signify sending to a higher authority (eg Acts 23:21) but its use in 23:11, where Herod sends Jesus back to Pilate, suggests that this is reading too much into it. ${ }^{6}$ Several motives have, however, been suggested by modern scholars. Assuming the historicity of the proceedings before Herod, Mommsen, Römisches, pp 356-357, suggested that in the early principate a trial was conducted in the home province of the accused (forum domicilii), but this law was later changed so that the accused was tried in the province in which his crime was committed (forum delicti). Sherwin-White, however, successfully
} 
the governor seizes a convenient opportunity to rid himself of an irritating case in which he is being pressurized by members of the Jewish nation to try a man whom he considers harmless ${ }^{1}$. The reference to Galilee gives a way out of the stalemate between Pilate and the chief priests: by handing the whole case over to Herod, Pilate need have nothing further to do with it.

The Roman prefect is too weak to insist on releasing the prisoner he has proclaimed innocent. Instead, he passes the case onto someone else, relinquishing Roman control over an allegedly political revolutionary and handing him over to the jurisdiction of a native prince ${ }^{2}$. Again, hardly a favourable picture of the Roman judge.

\section{The Trial before Herod Antipas, v:8-11}

Although a thorough consideration of the proceedings before Antipas is not within the scope of the present study, some features within it need to be highlighted.

Superficially, Luke's readers might expect the pro-Roman Herodian tetrach automatically to side with Pilate ${ }^{3}$. But Luke has incorporated several references to him throughout his gospel which add tension to this encounter. In 3:19-20 we learn something of his character: he shut John the Baptist up in prison because he reproached him for his marriage to Herodias and for all the evil things which Herod had done. In 9:7-9 we find out that Herod beheaded John the Baptist and that he was perplexed by Jesus and wanted to see him. By 13:31 even the Pharisees are warning Jesus to 'get away from here, for Herod wants to kill you' ${ }^{4}$ and Jesus sends back the message that he intends to

challenged this, suggesting instead that at the time of Jesus trials occurred in the province in which the crime took place (forum delicti); Roman, pp 28-31. This fits in with Felix trying Paul for misdeeds in Jerusalem, even though his home province was Cilicia (Acts 23:3424:26). In this case, Pilate was not compelled to hand Jesus over to Antipas. It is sometimes suggested that Pilate wanted to placate Antipas for the slaughter of the Galileans in 13:1.

${ }^{1}$ Although commenting on Pilate's historical reasons for sending Jesus to Antipas, Hoehner reaches a similar conclusion, 'Why Did'.

${ }^{2}$ Several scholars suggest that Pilate wished to obtain Herod's opinion, rather than to transfer the case to him, eg. Marshall, Gospel, p 854; Verrall, Christ, pp 332-333; Manson, Gospel, p 256; Brown, Death, pp 766ff. If the trial before Herod were historical, then this might have been the case. However, it is not the impression which Luke's narrative conveys; 23:15 clearly suggests that Herod could have dealt with Jesus in an appropriate way had he found him guilty, he seems to have been under no obligation to return the prisoner. See Schürer, History, vol i (rev), p 349.

${ }^{3}$ He was, after all, dependent upon Roman support for his position (see chapter 1); Evans, Luke, p 854, makes the same point.

${ }^{4}$ Verrall seems to be ignoring the plain meaning of the words when he claims: that we are to infer anything positively about the tetrach, seems impossible, since anything material to such an inference is undetermined' ('Christ', p 330) and 'it was not in the design of this author to prepare us for enmity on the part of Herod against Christ' ('Christ', p 329). See Brown, Death, 
go to Jerusalem, 'for it cannot be that a prophet should perish away from Jerusalem' (13:32-33). In 23:8-11 this long-awaited meeting takes place and the reader cannot help but fear that Jesus will suffer the same fate as John the Baptist.

23:8 recalls 9:9, stating that Herod wanted to see Jesus because of his reputation and hoped to see him perform a sign ${ }^{1}$. But despite the tetrach's repeated questions in v:9, Jesus makes no answer. In v:10 we are made aware that the chief priests and scribes have followed Jesus to Herod and stand about vigorously making accusations, though the content of these is not specified. Perhaps disappointed or annoyed by Jesus' silence ${ }^{2}$, Herod proceeds to treat Jesus contemptuously with the aid of his soldiers ${ }^{3}$. The only mockery in Luke's account is by Jewish leaders at 22:63-65, Jewish leaders and soldiers 4 at 23:35-37 and at this point at the Herodian court. There is no humiliation at the hands of Roman soldiers (as in Mk 15:16-20). This seems to be a deliberate attempt to remove the mockery of Jesus from Roman hands; Luke wants to show that Jesus was respected by Roman authorities ${ }^{5}$. The evangelist is obviously more interested in whitewashing Pilate than Herod. Clearly, in Herod's view, any claims Jesus may have made are utterly worthless and contemptible; so much so that he gives Jesus a gorgeous robe, a magnanimous gesture indicating that he is no threat to the tetrach ${ }^{6}$. Jesus is then sent back to Pilate.

In v:12 Luke adds a curious note explaining that Herod and Pilate became friends from that day on. The reason for their former enmity is not obvious from Luke's account; it may have arisen from Pilate's slaughter of the

p 769 who writes that Luke's statements give 'the impression of an unstable character capable of homicidal violence'.

IFor Luke's use of signs see Brown, Death, p 770.

${ }^{2}$ Grundmann, Evangelium, p 425.

${ }^{3}$ The textually uncertain $k \propto$ in $v: 11$, if original, may stress the tetrach's involvement; 'even Herod' or 'also Herod'; see Metzger, Textual, p 179. Verrall rightly notes that Herod's behaviour mocks the Jewish accusers as much as Jesus, 'Christ', p 342.

${ }^{4}$ On their identity see an earlier note in the present chapter.

${ }^{5}$ Goulder, Luke, p 756. A further reason for moving the mockery up to this point is that it allows Pilate to hand Jesus over directly to the Jews for crucifixion in 23:25ff, thereby enhancing the impression that they actually crucify Jesus.

${ }^{6}$ Many commentators take this robe as further mockery of Jesus' messianic claims. Loisy, followed by Creed and others, thought that Luke had deliberately omitted any reference to colour so as not to show Jesus aping imperial purple. Since some Latin MSS describe the robe as albus, Danker suggests that Luke has in mind the white toga worn by political aspirants in Polybius' History 10.5.1 (Commentary, p 465). Fitzmyer, however, asserts that there is no suggestion that the robe had anything to do with Jesus' alleged kingship, 'it is chosen to mock his guiltlessness' (Gospel, p 1482). 
Galileans in 13:1 but this is far from clear ${ }^{1}$. What is important within Luke's narrative is that the trials of Jesus have brought two very different rulers together: both are united in their estimation of Jesus' harmlessness. The same pattern has emerged with Herod as with Pilate: Luke's narrative has prepared the reader to expect each ruler to be antagonistic towards Jesus, an expectation which makes their casual assumption of his innocence all the more noteworthy. This is particularly surprising in that Jesus has done nothing at all to try to court either one's favour.

\section{Pilate's Summing Up, v:13-15a}

The case has been returned to Pilate. The previously unwilling judge at first appears to act with a certain amount of decisiveness. He takes the initiative and summons the chief priests, rulers ${ }^{2}$ and the people together and delivers his verdict. The practical problems in summoning these groups of people do not seem to worry Luke ${ }^{3}$; nor does the fact that the chief priests and scribes have been present at the interview before Herod ( $v: 10)$ and may be presumed to have accompanied Jesus back to the court of the governor. What is important is that both the Jewish people and their leaders hear Pilate's second declaration of Jesus' innocence in v:14 and that they all together will convict their messiah 4 .

After reiterating the main charge, that of perverting the people, Pilate

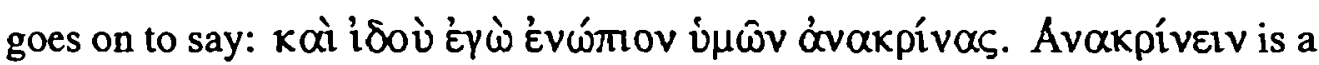
technical term corresponding to the Latin cognitio referring to an examination by a magistrate, eg Acts 4:9, 12:19, 24:8, 28:18. But Pilate has not examined the prisoner already; he has refused to become involved in the case and passed the prisoner on to Herod. The readers may suspect that he is once again trying to avoid dealing with the prisoner. For the second time, Pilate declares Jesus innocent, adding that Herod too reached the same conclusion

\footnotetext{
${ }^{1}$ Taking 23:12 and the trial before Herod as historical, this is Blinzler's suggestion ('Niedermetzelung', pp 24-49); Hoehner (Herod, pp 175-176) and Goulder (Luke, p 759) suggested that the enmity was caused by the incident concerning the gilded shields narrated by Philo, Leg 299-305.

${ }^{2}$ Referring probably to the lay nobility as at $19: 47$, possibly also the scribes; Grundmann, Evangelium, p 425.

${ }^{3}$ The same verb $\sigma 0 \gamma \kappa \alpha \lambda \varepsilon^{\prime} \omega$ is used in Acts 5:21 and 28:17 of calling together a council; Matera, 'Lk 23, 1-25', p 548.

${ }^{4}$ Luke 'stresses the representative and authoritative character of the audience', Evans, Luke, p 853.
} 
since he sent him back ${ }^{1}$. Clearly the Lukan readers are to assume that Herod would have put Jesus to death had he found him guilty of any of the charges (as presumably in 13:31). Pilate has now provided the two witnesses required by Dt 19:15 to Jesus' innocence ${ }^{2}$; both are influential people whose opinion would not be dismissed lightly, one a Roman governor, the other a Jewish tetrach.

Conflicting Verdicts, $v: 15 b-23$

Pilate says that Herod has returned Jesus $\pi p \grave{s} \varsigma \dot{\eta} \mu \alpha \hat{c}$. But why does he say 'to us', that is, to the governor along with the representatives of the whole Jewish people, instead of 'to $\mathrm{me}^{\prime 3}$ ? This seems to be the first indication that the people are going to have a say in the fate of Jesus. The judge of Jesus will no longer be Pilate alone but the chief priests, rulers and Jewish people.

The scene continues with three sets of parallel verdicts: each time Pilate tries to release Jesus and each time the crowd shout against him. Whilst Pilate's verdict remains virtually the same all three times, that of the crowd becomes more intense, heightened by the use of forceful verbs such as

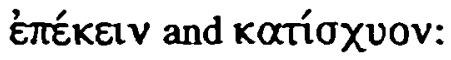

PILATE

1

(Behold, nothing deserving death has been done by him); I will therefore chastise him and release him (15b-16).

\section{CROWD}

Away with this man (and release to us Barabbas) (18)

II

Pilate addressed them once more, desiring to release Jesus (20)

III

(Why, what evil has he done? I have found in him no crime deserving death;) I will therefore chastise

Crucify, crucify him (21)

But they were urgent, demanding with loud cries that he should be crucified. (23)

\footnotetext{
1 oủó may have the sense of 'not even Herod'; if so, Pilate may mean that Herod, as a Jew, might be more easily expected to see what crime had upset the Jewish leaders in Jerusalem.

In the same way that two witness attest that Jesus is the promised messiah at the beginning of the gospel (Simeon and Anna in 2:22-38), so now Luke has provided two witnesses at the end of Jesus' life to emphasize that Jesus is no political threat; Grundmann, Evangelium, p 424.

${ }^{3}$ Despite the textual vanant here ('for I sent you to him', supported by $A, B, D, \Delta$ and others) this is the most likely reading; see Metzger, Textual, p 179.
} 
him and release him (22).

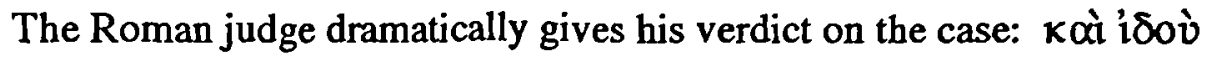

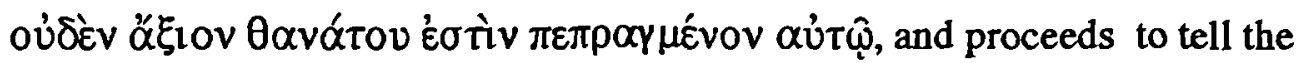

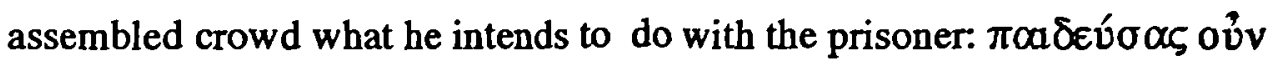
$\alpha \hat{T}$ òv $\dot{\alpha} \pi \mathrm{\lambda} \lambda \hat{v} \sigma \omega$. But this sentence does not follow from his previous verdict: if Jesus is not guilty of any of the Jewish charges and does not deserve death, why then does Pilate say 'therefore' I will teach him a lesson? He seems to be suggesting that he give Jesus a milder disciplinary beating rather than the flagellatio administered before crucifixion in Mk 15:16-201; the lighter beating was often associated with a warning, when the governor decided that the situation did not require a formal cognitio, for example when dealing with juvenile gangs or acts of negligence ${ }^{2}$. Again Pilate seems to be trying to avoid a formal trial; yet the very fact that he has declared Jesus innocent but is willing to give him a mild beating to placate the crowd shows that already he is bowing to Jewish pressure.

The chief priests, rulers and crowd also give their verdict: Aipe Tov̂Tov, a cry which is echoed later in connection with Paul in Acts 21:36, 22:22 (and Is 53:8). Instead of Jesus, they demand the release of Barabbas, one who was certainly guilty of perverting the nation by his insurrectionary activity.

Again in v:20 Pilate gives his verdict, wishing to release Jesus, and again the crowds give their verdict against the prisoner. This time they

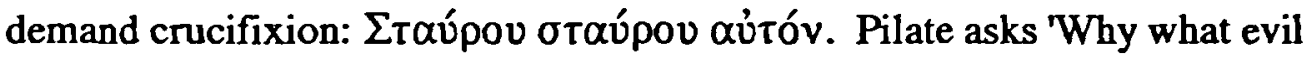
has he done?' and repeats his earlier verdict of $15 \mathrm{~b}-16$. The crowds shout back even louder for crucifixion. Their cries reach a crescendo until in $23 \mathrm{~b}$ Luke records that their voices prevailed. In this brief phrase Pilate has lost all credibility as a Roman governor and judge: his feebly repeated verdict is swept aside by the demands of the people he was sent to govern.

\footnotetext{
${ }^{1}$ On the basis of Dig 28.19.7, Sherwin-White suggests that there were three grades of beatings in the empire: fustes, flagella and verbera, Roman, p 27. Although the precise differences between them are uncertain, $\pi 0 a \delta$ Evelv (meaning 'to bring up', 'educate', instruct' or 'correct') seems to correspond to the lightest of these, the fustigatio, or disciplinary beating; so Evans, Luke, p 854; Grundmann, Evangelium, p 426. Fitzmyer not very convincingly suggests that Pilate is using an euphemism for flagellatio here, 'probably to salve his own conscience', Gospel, p 1484.

${ }^{2}$ See Sherwin-White, Roman, pp $27 f$ for references.
} 
Luke is the only gospel to admit that Pilate passed sentence, but he makes it plain that it reflects the crowd's verdict, not the Roman governor's: 'so Pilate gave sentence that their demand should be granted' 1. It is not so much a condemnation of Jesus as a decision that what the priests, leaders and people want should be done ${ }^{2}$. The final verse is almost pitiful. Pilate meekly hands over an insurrectionary and murderer, a political rebel against Rome in response to the demand of the people he is supposed to govern. It must be remembered that there has been no armistice or privilegium paschale in Luke. The fate of Barabbas has nothing whatsoever to do with that of Jesus in Luke's presentation; Pilate does not have to release either prisoner. The effect of this is that Pilate's actions are all the more reprehensible: not only does he allow a man to be crucified whom both he and Herod have found innocent ${ }^{3}$, but he releases a political prisoner simply because the crowd ask for it. In the govemor's court injustice has triumphed over justice.

\section{Conclusion}

In a drastic revision of his Markan source, Luke's major apologetic purpose in 23:1-25 is to use Pilate as the official witness to Jesus' innocence and to lay the blame for Jesus' crucifixion first on the intrigues of the chief priests (v:1-12) and then on representatives of the whole Jewish nation ( $v: 13$ 25). This scheme continues throughout Acts where Roman involvement always follows Jewish plots. But once Pilate has three times declared Jesus innocent, Luke does not seem intent upon painting a glowing picture of Roman administration. In fact, quite the reverse seems to be the case. As Talbert notes, 'Pilate appears more as an advocate who pleads Jesus' case than as a judge presiding over an official hearing' 4 . He refuses to become involved with the charges and simply declares Jesus innocent. He does not want to bother with the case and seizes on the opportunity to pass Jesus on to Herod. But Herod, who does question Jesus at length, albeit for self-interested motives, sees Jesus as no threat and returns Jesus to the governor. Pilate

\footnotetext{
1'̇лźxptvev in v:24 has the technical nuance of issuing an official sentence; see also 2Mace 4:47, 3Macc 4:2.

${ }_{2}$ Matera, 'Lk 23,1-25', p 549; Walaskay, And So, p 44.

${ }^{3}$ Luke has hughighted Pilate's culpability in that be gives sentence contrary to both his own opinion and that of Herod; Verrall, 'Chnst', p 339.

4Talber, Reading, p 217.
} 
seems in control, it is he who summons the three Jewish groups, but he soon shows signs of weakness. Eventually he convicts a man whom he has declared innocent and releases a rebel and murderer because of the demand of the people. Bowing to Jewish pressure not only undermines his own judgement but also that of Herod. In the end, Jewish mob-pressure has triumphed over Roman justice. The weak Pilate has let down not only himself as a governor and judge, and Herod, but also the Roman administration he is supposed to represent.

This presentation of Pilate is consistent with the references to him in Acts. 13:28 simply states that the people of Jerusalem and their leaders asked Pilate to have Jesus killed though they could charge him with nothing deserving death. 3:13 charges the people of Israel with delivering Jesus up and denying him in the presence of Pilate who had decided to release him. Both these passages lay the blame for Jesus' crucifixion on the Jewish people, their leaders or both. Acts 4:25-28, however, does not contain such extreme anti-Jewish bias and, after quoting Ps 2:1-2, reads:

'for truly in this city there were gathered together against thy holy servant Jesus, whom thou didst anoint, both Herod and Pontius Pilate, with the gentiles and the peoples of Israel, to do whatever thy hand and thy plan had predestined to take place'. (4:27-28, RSV).

Obviously, Luke would not have included the psalm and the subsequent commentary on it if he felt it was completely at variance with his presentation of the Roman trial. Although he clearly wants to lay the bulk of the blame on the Jewish chief priests, Pilate's lack of interest and weakness inevitably lead him to a place in this evil alliance. The Roman governor has not been whitewashed.

In this way, Pilate's characterization conforms to that of other Roman judges in Luke-Acts; Luke always draws a distinction between Roman law which sees no harm in Christianity and its weak or even corrupt governors through whose incompetence Jewish opponents of the new movement could claim some victories.

Finally, what does this portrayal of Pilate tell us about the perception of Rome held by Luke's community? For over two and a half centuries the widely held scholarly consensus has been that Luke composed his two volume work as an apology for Christianity addressed to a Roman magistrate, Theophilus ${ }^{1}$. Yet this theory is not without serious flaws. First, there is no

${ }^{1}$ This view was first put forward by C.A. Heumann in 1721; for a similar interpretation see Cadbury, Making, pp 5-7. For a history of research into Luke's political apologetic see 
suggestion in the two-volume work of widespread persecution or injustice at Roman hands which would necessitate such a work. Secondly, Luke's narrative is dotted with several anti-Roman references; for example, he openly refers to Simon as a zealot (Lk 6:15, Acts 1:13), he makes no attempt to cover up Jesus' command to buy swords ( $\mathrm{Lk} 22: 35-38$ ), nor does he attempt to cover up the kingly aspect to Jesus' messiahship (Lk 19:38). This would be extremely curious if Luke were writing for a non-Christian Roman audience ${ }^{1}$. Thirdly, the portrayal of Pilate which we have just seen and his fellow Roman govemors would hardly commend itself to a Roman official. True, Pilate declared the leader of Christianity innocent, but any Roman magistrate would surely be suspicious of the legality of the trial which Luke presents. Pilate seemed reluctant to try the case, not even exploring two of the charges. Nor is Pilate recommended by his character; he is weak and manipulated. It is difficult to imagine a Roman official reading Luke's account and feeling reassured that Christianity was no threat to Roman law and order.

More recently, Walaskay has turned the traditional theory around, arguing that Luke-Acts is not an apology for the church but an apology for Rome directed at Luke's own community. Some perhaps tended to deprecate the imperial government; some may have 'anxiously awaited the coming of the Lord and saw little value in developing a dialogue with the enduring state'; all would have been attempting to work out their new social relationship with the empire without the prop of Judaism². Again, this theory is not without its drawbacks. Most importantly, whilst it is clear from Luke-Acts that the relationship between Luke's community and Judaism was an important issue, there is no evidence for either the deprecation of Rome or an expectation of an imminent parousia within the two writings. Furthermore, if it were Luke's purpose to portray Rome in a positive way, why has be included inconsequential details which only serve to show the representatives of Rome in a poor light, for example Felix hoping for a bribe (Acts 24:26) or Pilate's slaughter of the Galileans (Lk 13:1). Luke's readers would hardly be impressed by the picture of Pilate which the evangelist presents. Pilate's most

Walaskay, And So, pp 1-14. This view is still held by some, eg Fitzmyer, Gospel, p 10; Evans, Luke, pp 108-111.

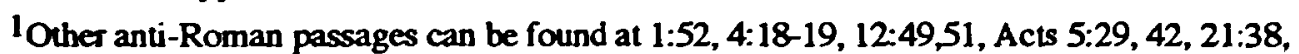
28:31. For a fuller discussion see Walaskay, And So, pp 15-22. See also Cassidy, Jesus, who argues on the basis of these and other references that Luke has no political apologetic directed towards Rome.

${ }^{2}$ Walaskay, And So, pp 64-67. A similar view was put forwand by Maddox, Purpose, pp $96 \mathrm{ff}$ who suggested that Luke was trying to cultivate a sober, inoffensive style of life and attitude towards the Roman govemment such as that advocatod in Rom 13:1-7 and 1Pet 2:11-17; the evangelist was anxious to avoid both Chrisuan self-assertuveness towards Rome and voluntary martyrdoms. 
important function is to provide an official proclamation of Jesus' innocence under Roman law; why would this be needed in such a community?

Another more likely solution to this problem has come from Esler.

Like Walaskay, he assumes that Luke is writing to address internal problems within his community rather than the non-Christian Roman world at large. According to Esler,

'among the members of Luke's community were a number of Romans serving the empire in a military or administrative capacity, ... part of Luke's task was to present Christian history in such a way as to demonstrate that faith in Jesus Christ and allegiance to Rome were not mutually inconsistent'1.

Luke's narrative shows that the state was on Jesus' side and that to confess yourself a Christian was no crime against Roman law 2 .

This would account for Luke's interest in Rome generally and also why the Roman trial occupies such an important position in his narrative. Such a readership would also account for the negative portrayal of Roman governors: if Roman law found Jesus and Paul innocent (as Luke stresses), then their deaths need to be accounted for by other means; for Luke, God's purposes are effected by a combination of Jewish machinations and the weak or depraved characters of the Roman governors before whom Jesus and Paul were brought. Christian Romans would presumably not feel offended by these portrayals as the pages of Luke and Acts are full of positive pictures of Romans with whom they could identify, including Paul himself. For such a community Luke's presentation of Pilate served an invaluable role in both officially proclaiming Jesus' innocence under Roman law and at the same time through his weak, malleable, ineffectual character providing the means by which Jesus' Jewish opponents were able to have him executed.

\footnotetext{
${ }^{1}$ Esler, Community, p 210; he also suggests that Luke wanted to appeal to Roman Christians by stressing the ancestral nature of Christianity in a similar way to Josephus' concern to emphasize the ancestral nature of Judaism in his Antiq, pp 212-215.

${ }^{2}$ See Goulder, Luke, p 761; Conzelmann, Theology, p 140.
} 


\section{CHAPTER 7}

\section{Pilate in John's Gospel}

Virtually all scholars are in agreement that John's gospel was written for a Christian community which had recently and traumatically broken away from, or been expelled from, the Jewish synagogue ${ }^{1}$. There are points of similarity here with Matthew in that despite the Jewishness of many parts of the gospel ${ }^{2}$, the author is vehemently hostile towards his Jewish neighbours. The work seems to presuppose the fall of the temple in $\mathrm{AD} 70^{3}$ but, since the discovery of the Rylands papyrus, cannot be later than about AD 100-1104. Most scholars are agreed that a date of roughly $85-95$, that is, the reign of Domitian, would fit well with the circumstances to which the gospel is addressed 5 .

\footnotetext{
1 In 9:22, 12:42 and 16:2 all refer to this expulsion. See in particular Martyn, History; Brown, Community; Meeks, 'Breaking'; Segovia, 'Love'; Kysar, 'John'; Hengel, Johannine; and commentaries of Schnackenburg, Barrett and Lindars.

${ }^{2}$ For example the allusions to Gen $1: 1$ in the prologue, the references to the passover $(2: 13$, $6: 4,11: 55$ and 13:1), and the frequent use of OT images (10:11, 15:1-4, 6:51). For a fuller discussion of both the Jewish and Hellenistic background to John's gospel see Barrett, John and Judaism; Brown, Gospel, pp lii-lxvi; Schnackenburg, Gospel, pp 119-149.
}

The author of the gospel has traditionally been seen as either John the son of Zebedee, John the Elder of 2 and 3 John or the Beloved Disciple (who may be either of the first two). Many scholars are content to accept that we do not know the author's identity (eg Kysar, 'John', p 920; Lindars, Gospel, pp 28-34). Hengel maintains that is was John the Eder(Johannine, pp 102-108); Barrett, Brown and Schnackenburg suggest a disciple of John son of Zebedee (Brown tentatively suggests that this may have been John the Elder). For a fuller discussion see Barrett, Gospel, PP 100-127; Brown, Gospel, pp Ixxxvii-cii; Schnackenburg, Gospel, pp 75-104.

${ }^{3}$ This is suggested by the fact that the Sadducees and the scribes familiar to us from the synoptics are no longer present; instead, the Pharisees have emerged as the undisputed leaders of Judaism, suggesting conditions after AD 70. Also 2:13-22 may be an attempt to present Jesus as the replacement of the destroyed temple, Kysar, 'John', p 919.

${ }^{4}$ The Rylands Papyrus 457, ${ }^{52}$, was found in Egypt and is probably to be dated at about $\mathrm{AD}$ 125-150. Since it is very unlikely to have been the original, some time must have elapsed for the gospel to be known and copied.

5Some scholars, eg Martyn, History, have tied the conflict in John to the promulgation of the birkath ha minim, an amendment to the 12 th of the 18 Benedictions at the time of Gamaliel II (80-115) in Jamnia which excluded Christians and heretics from the synagogue.

Unfortunately, we are sure of neither the exact date nor the precise wording of this 'benediction'. Besides, the conflict in John seems to stem from local synagogues and their leaders rather than with a central decision from Jamnia. Historically, it is likely that problems with local synagogues and their decisions eventually led to the formulation of the birkath ha minim. It is probably at this stage that the Jewish/Christian conflict described in John's gospel (and also in Matthew's) is to be located. See Hengel, Johannine, pp 114-115; Meeks, 'Breaking', who refers to the birkath ha minim as 'a red herring in Johannine research', p 102.

Lindars suggests a date of 85-95 (Gospel, p 42); Barrett suggets $\mathrm{c} 100$ (Gospel, p 128); Brown puts it at 90-100. The latter is probably correct in his assertion that the gospel 
Locating this community is not an easy task. Suggestions have ranged from Alexandria, Antioch (or elsewhere in Syria) ${ }^{1}$ to Batanaea or lower Galilee $^{2}$. Ephesus, however, is the traditional place of authorship ${ }^{3}$ and this city has several points in its favour. First, though few would hold that the author of John's gospel also wrote Revelation, the two works may have come from the same community and Revelation explicitly mentions Ephesus (1:11,2:1). There was also a strong and influential Jewish community in Ephesus (Acts $18: 19,2428 ; 19: 8-20)^{4}$ which seems to have been engaged in bitter disputes with the Christian community (Rev 2:9). Furthermore, Ephesus was the capital of the Roman province of Asia and this dominant Roman regime would explain John's interest in Jesus' Roman trial. Though none of these points are conclusive and certainty is impossible, the following discussion will take Ephesus as the general area of composition 5 .

\section{Context}

Apart from the chiliarch and the soldiers at Jesus' arrest (18:3), Pilate is the only Roman with whom Jesus comes into contact. As in the synoptic gospels, the governor plays his part in the passion narrative as the judge of Jesus at 18:28-19:16a. In 19:19-22 John has added another story describing a dispute between Pilate and 'the Jews' regarding the title on the cross. Finally Pilate makes a brief third appearance at 19:38 when, as in the synoptic gospels,

underu ent several revisions (he suggests five) before it reached its final form (Gospel, pp Ixxx-lxxxvi; see also Hengel, Johannine, pp 102ff).

${ }^{1}$ Dodd, Johannine, pp xxxix-xli, highlighted the parallels between 1John and Matthew, suggesting that John's gospel, like Matthew, originated at Antioch. However this depends upon Matthew having been written in Antioch which is far from certain (see chapter on Pilate in Matthew).

${ }^{2} \mathrm{Eg}$ Wengst, Bedrängte, suggested the Southern part of Agrippa II's kingdom. Due to the importance of 'Galıleans' and 'Samaritans' in John's gospel and the lack of any explicit reference to the dominant pagan society, Meeks suggests the gospel was composed in a Greek city of lower Galilee, 'Breaking', pp 94-104. Lindars, Gospel, pp 43-44 and Hengel, Johannine, p 115, doubt a Palestinian origin. Furthermore, Bassler, 'Galileans', has shown that the terms 'Galileans', 'Samaritans' and 'Jews' are symbolic designations relating not to ongin but faith.

${ }^{3}$ Irenaeus, Adv Haet 2.22.5 and 3.3.4 (quoted by Eusebius $H E$ 3.23.3f and 4.14.3-8).

${ }^{4}$ For the prominence and influence of Jews in the cities of Asia Minor see Hengel, Johannine, p 116.

5 Although he admits the case is 'not strong', Ephesus is favoured by Barrett, Gospel, p 131; Lindars is uncertain between Ephesus and Syria, Gospel, p 44; Brown, Gospel, pp ciii-civ; Lghtfoot, St John's, p 2 and Hengel, Johannine, pp 109 if all favour Ephesus.

Schnackenburg seems to want to have the best of all possibilities when he suggests that the Johannine tradition ongunated in Palestine and was subjected to Syrian influences before it was wntten down in Ephesus, Gospel, p 152. 
Joseph of Arimathea asks for Jesus' dead body. The text for the trial is as follows:

18.28 "A

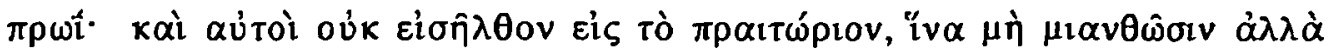

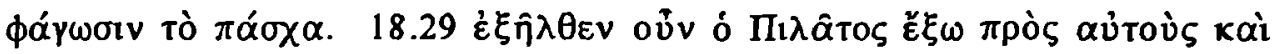

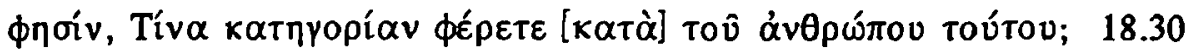

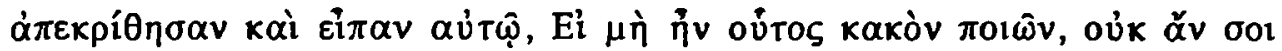

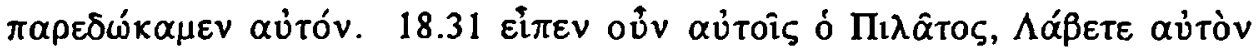

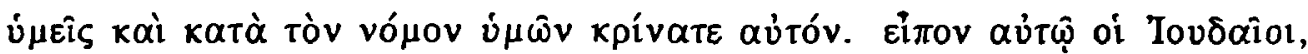

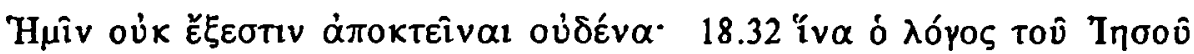

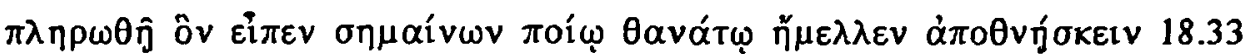

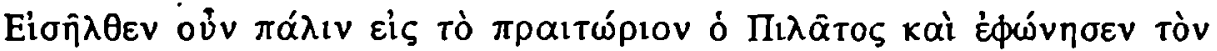

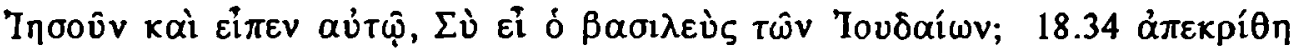

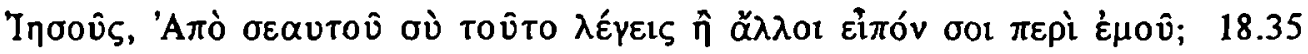

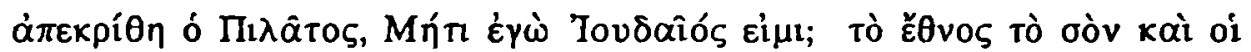

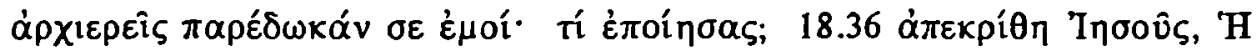

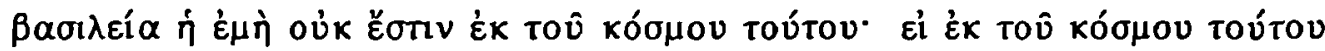

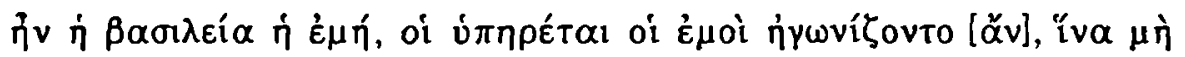

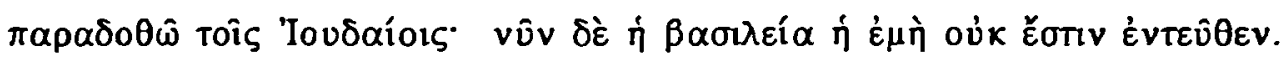

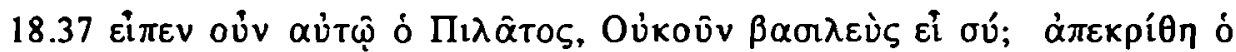

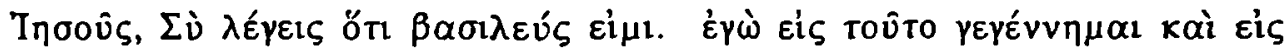

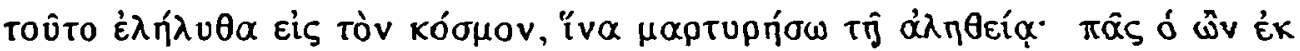

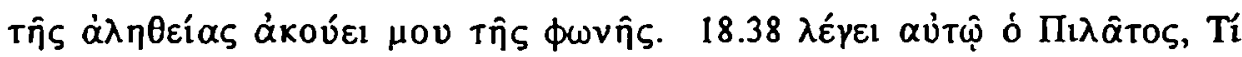
$\dot{\varepsilon} \sigma \pi v \dot{\alpha} \lambda r^{\prime} \theta \varepsilon 1 \alpha$;

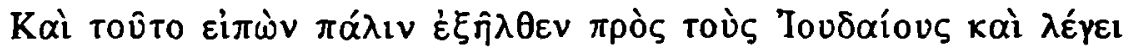

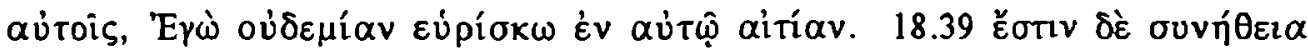

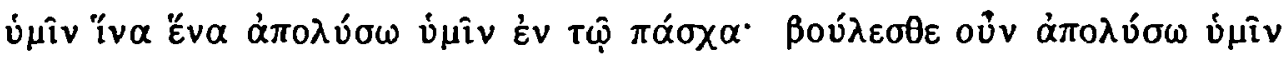

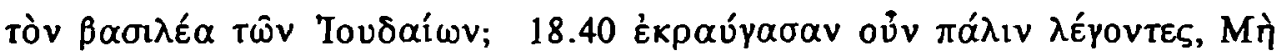

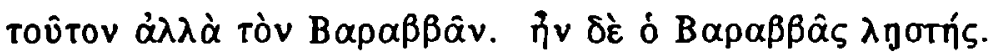

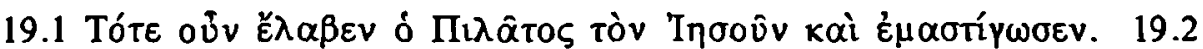

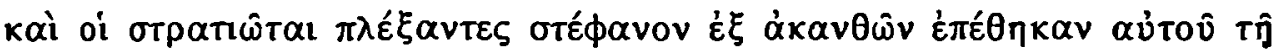

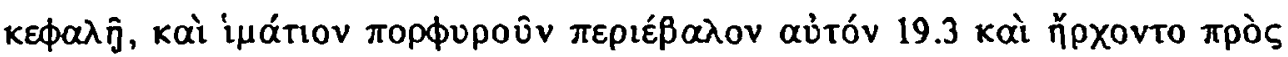

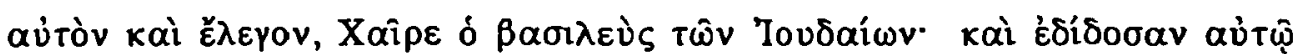

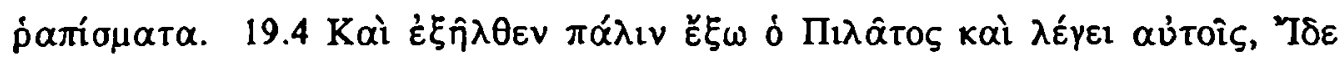

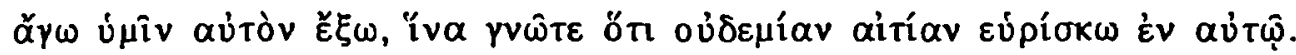

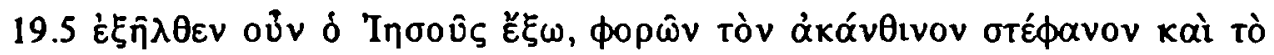

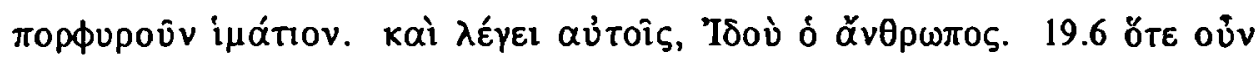

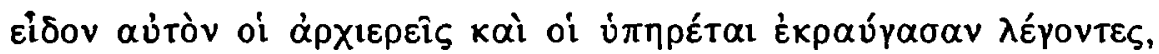




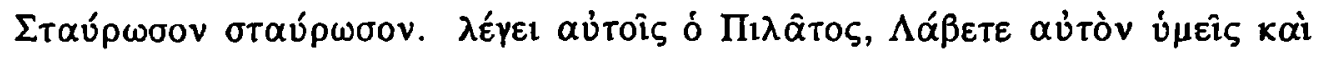

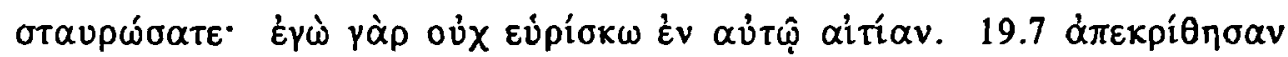

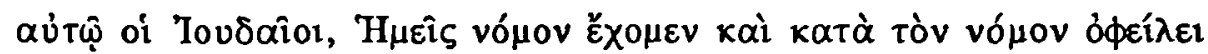

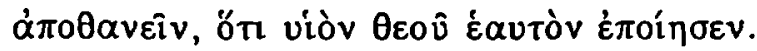

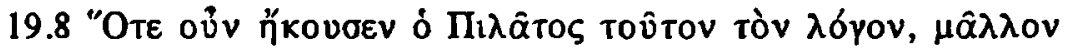

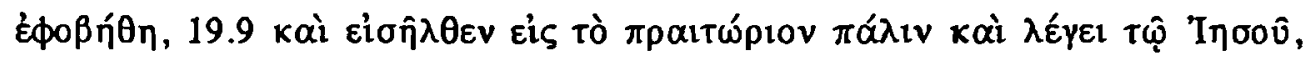

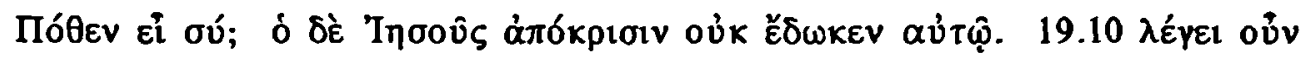

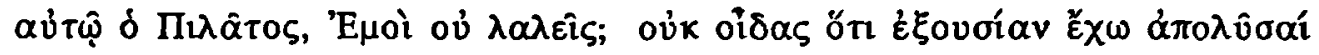

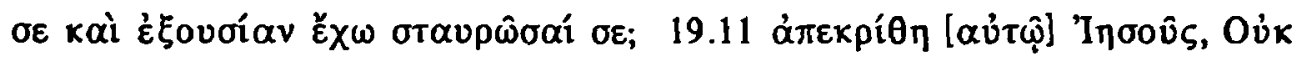

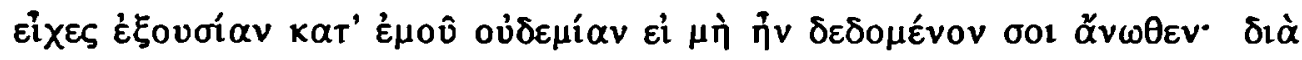

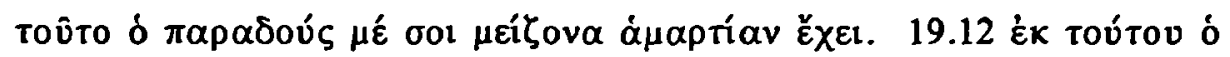

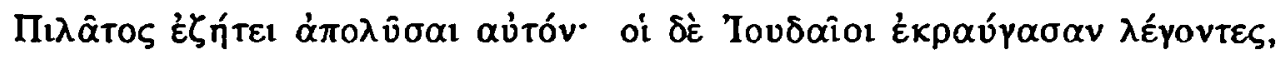

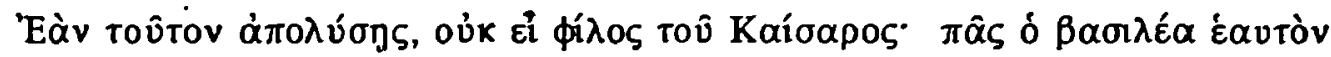

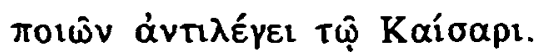

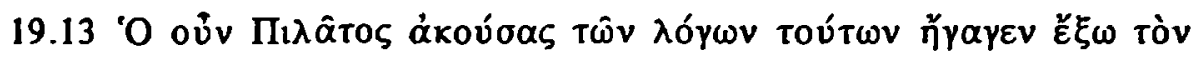

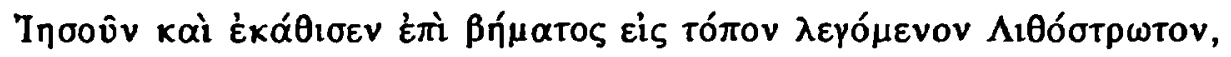

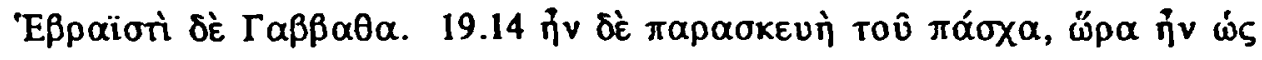

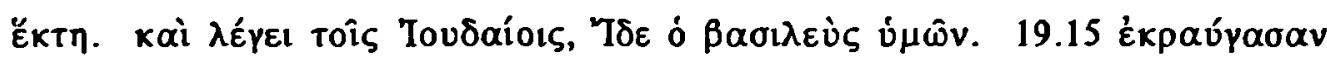

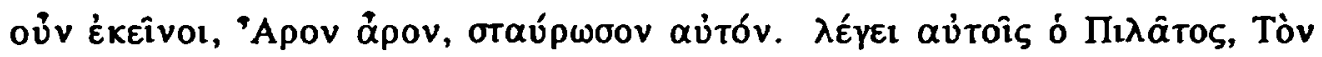

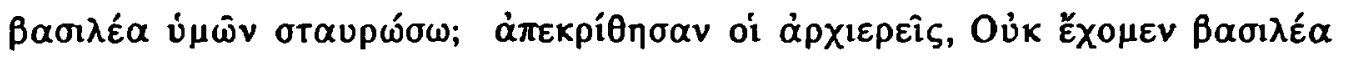

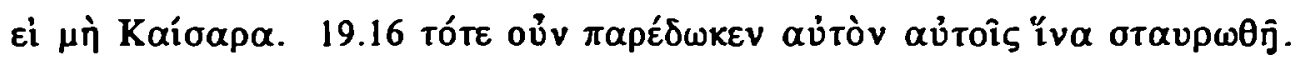

This chapter will take a brief look at the sources behind John's passion account and important Johannine themes which have shaped his portrayal of the Roman trial narrative before turning to evaluate the characterization of Pilate in this gospel. After this we shall have looked at the description of Pilate in all four gospels and it should be possible to draw some picture of the historical events behind the various Roman trial narratives.

\section{Sources Behind John's Passion Account}

Whether we can assume that John and his readers were familiar with the synoptic passion accounts is uncertain. At one extreme, several scholars assert that John knew and used Mark, Luke or all of the Synoptics's. At the other end of the scale, others think that John did not make use of any synoptic gospel or

\footnotetext{
${ }^{1}$ Examples are Barrett, Gospel, pp 34f; Lee, 'St Mark' (dependence on Mark); Bailey, Traditions, p 121 (dependence on Luke); Sabbe, 'Tnal', and Neirynck, 'John', (both argue John was dependent on the Synoptics).
} 
synoptic sources and was dependent instead on an independent passion source $^{1}$. A more moderate view, and one which will be assumed throughout this chapter, is that John was acquainted with some of the sources or traditions behind Mark (and possibly Luke), or ones similar to them, but not necessarily with any of the Synoptics in their final form ${ }^{2}$. The major reason for accepting Johannine knowledge of at least the traditions behind Mark is that the portrayal of Pilate which emerges from John's gospel has several points of similarity with that in Mark, as will become clear in the following discussion.

\section{Important Johannine Themes Culminating in the Trial before Pilate}

1) The Roman trial narrative occupies an important position within John's narrative. The proceedings are much longer than those found in the Synoptics. The importance is emphasized further by the lack of any formal Jewish trial in this gospel. Features belonging to the synoptic account of the Jewish trial are found scattered throughout the Fourth Gospel, especially in chapter 10 where 'the Jews' ask Jesus if he is the Christ and then accuse him of blasphemy (vv:22-39). Nor is the reader ever in any doubt that 'the Jews' want to arrest Jesus $^{3}$ or even to kill him ${ }^{4}$. In 11:47-53 the Sanhedrin meet and, apparently in Jesus' absence, condemn him to death. Yet John records no formal Jewish trial of Jesus before he is handed over to Pilate; Jesus is taken to Annas (18:13)

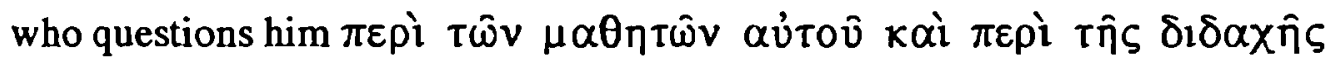
$\alpha$ U่ Tov (18:19) and then sends him to Caiaphas (18:24). The reason for Jesus' appearance before Caiaphas is not entirely obvious. Certainly Annas does not pass any formal sentence and John twice makes it clear that Annas is not the High Priest $(18: 13,24)$. If there is to be any formal Jewish conviction of Jesus it should be before Caiaphas in his official capacity as High Priest. Yet of any proceedings which may have occurred before Caiaphas, John is completely silent. The story of Peter's final two denials and the subsequent cock-crow is inserted between the sending of Jesus to Caiaphas ( $v: 24)$ and the sending of

\footnotetext{
${ }^{1}$ Exponents of this view include Gardner-Smith, St John; Bultmann, Gospel, pp 653f; Dodd Historical, Pt 1A; Meeks, Prophet p 18 n 4; Brown, Gospel, vol I p xlvi.

${ }^{2}$ This view is held by Buse, 'St John/Markan', pp 215-219 and 'St John/Matthew/Luke', pp 65-70; Borgen, 'John', pp 246-259, holds a view somewhere between the last two alternatives. 37:30, 32, 44 (here it is 'the people'), 45f, 10:39, 11:57.

${ }^{4}$ Whilst Mark has only one explicit statement of this, John has several: 5:16-18, 7:1,19,25, $8: 6,37,40,44,59,10: 31,11: 8,50,53$.
} 
Jesus to Pilate (v:28), thus masking the fact that John has said nothing about the meeting between Caiaphas and Jesus. In the Fourth Gospel, then, Jesus' only trial after his arrest is at the hands of the Roman prefect, Pontius Pilate.

2) Even a cursory reading of Jn 18:28-19:16a reveals a carefully formulated structure. Throughout John's gospel scholars have found many 'chiastic' structures ${ }^{1}$; that is, two parallel groups of ideas or actions in which the second group is the mirror image of the first, such as $A-B-C-C^{*}-B^{*}-A^{*}$. In general, however, except for isolated verses such as 16:28, these chiasms are not entirely clear: often parallel pairs are linked only by one or two words, often additional verses interrupt the parallelism. This lack of any formal structure is emphasized by the failure of different commentators to agree on exactly what the chiastic structure is in any particular passage 2 . Many of the chiastic 'structures' within the fourth gospel may reveal rather a tendency of the author to pick up previous ideas and themes, giving his writing an almost circular character at times.

In contrast, 18:28-19:16a do reveal a carefully ordered chiastic structure arranged not so much on content as the location of the individual scenes. Although Bultmann divided this section into six scenes (taking 19:1-8 as one unit $^{3}$ and Meeks adds 19:17-22 to the trial narrative ${ }^{4}$, the overwhelming consensus amongst scholars is that the verses are to be divided into seven divisions, a particularly significant number within John's gospel ${ }^{5}$. These are: 18:28-32, 33-38a, 38b-40, 19:1-3, 4-8, 9-11, 12-16. This structural division is emphasized primarily by the movements of Pilate between 'the Jews' who remain outside the praetorium and Jesus who, for most of the action, remains inside the praetorium. The action is arranged into two symmetrical groups, each with three scenes and centring on the scourging in 19:1-3. In each of the two groups, Pilate is outside the praetorium with 'the Jews' (and later Jesus) throughout the first and third scenes and inside with Jesus in the second scene.

This structure, which forces Pilate to move constantly between Jesus and his Jewish accusers, has often been used as a basis upon which to build

\footnotetext{
${ }^{1}$ In particular see Brown, Gospel; Leon-Dufour 'Trois Chiasmes', pp 249-255; Lund Influence', pp 27-48, 405-433.

${ }^{2}$ Compare for example Brown's 'structure' of 15:7-17, Gospel, p 667 with that of Borig, Wahre, pp 68f.

${ }^{3}$ Bultmann, Gospel, p 648.

${ }^{4}$ Meeks, Prophet, p 62.

5 For example, Jesus performs seven signs, gives seven discourses and, in 4:52, heals the official's son 'at the seventh hour'. For an alternative structure see Giblin, 'John's', pp 221 224.
} 
John's characterization of Pilate. It is common amongst commentators to see Pilate going from one group to another, vacillating and indecisive, or desperate to avoid making a decision ${ }^{1}$. Yet this approach has not paid sufficient attention to ancient literary methods. As Alter puts it:

The fixed practice of biblical narrative, with only a few rather marginal exceptions, limits scenes to two characters at a time - or sometimes, to the exchange between one character and a group speaking in a single voice as a collective interlocutor ${ }^{2}$.

John is clearly following this convention; in order to highlight the exchanges between Pilate/'the Jews' and Pilate/Jesus, he locates the dialogues in different settings, only in the fifth and seventh scenes does he allow all the characters to come together as in the synoptic accounts. The fact that Pilate moves inside and outside the praetorium therefore is most probably due to John's literary style rather than an attempt to make Pilate appear indecisive.

3) An important motif throughout the Johannine trial narrative is the emphasis on Jesus' kingship. Whilst John often refers to Jesus as 'Christ'3, the specific title 'king' is used only three times outside the trial narrative: 1:49, 6:15 and 12:13-15. The first occurs relatively privately when Nathanael describes Jesus as $\beta \alpha \sigma i \lambda \varepsilon \dot{v} \varsigma$ tov 'Iop $\alpha{ }^{\prime} \lambda$ in front of a small group of disciples. 'Israel' was the preferred Jewish self-definition ${ }^{4}$ and this title seems to have been the Jewish messianic version of 'the King of the Jews'5. After the

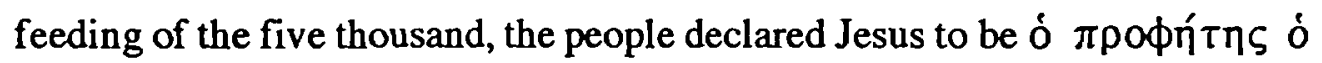

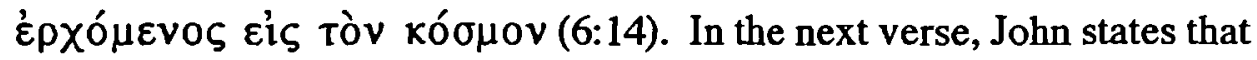
Jesus withdrew from the crowds because he perceived that they were about to make him king by force. This verse gives us two important insights into John's view of kingship. First, the evangelist clearly shows that Jesus is rejecting a political kingly role. Secondly, he shows his readers that popular support for Jesus was such that the crowds wanted to make him their king, although the use of the term 'prophet', which in Johannine thought is an inadequate description for Jesus, shows that the crowd had not understood his mission. Again at Jesus' entry into Jerusalem (12:13-15), he is hailed by the people as o

\footnotetext{
${ }^{1}$ Eg Stibbe, Storyteller, p 106.

${ }^{2}$ Alter, Art, p 72.

3 1:41, 4:25-26, 27, 7:26f, 31, 40f, 10:24, 11:27, 12:34, $20: 31$.

${ }^{4}$ Mayer, 'Israel', esp pp 310-311. The term 'King of Israel' is also applied to Yahweh in Is 41:21, 44:6.

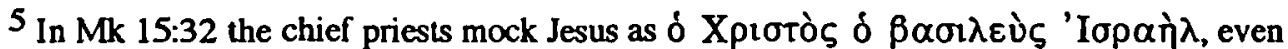

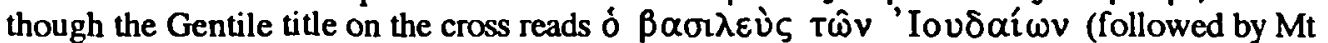
27:42; in Lk 23:37 the Gentile soldiers describe Jesus as 'the King of the Jews').
} 


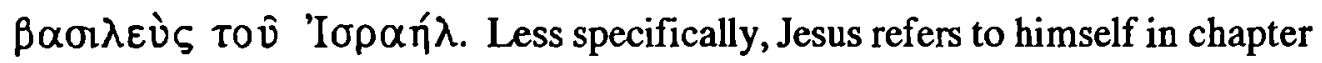
10:1-30 as the 'good shepherd'. In the OT, the idea of kingship, or the ruler of Israel, is often portrayed as a shepherd with his sheep; for example Zech 11 or the wicked rulers of Jer 23:1-4, 2:32-38, Is 56:9-12, Ez 34. David is a shepherd-king (Ps 78:70-72); the messianic prophecy of Ez 34:23 says: 'I will set up over them one shepherd, my servant David, and he shall feed them: he shall feed them and be their shepherd'. Num 27:17 calls for one to be as a shepherd to Israel: the one who is appointed is Joshua whose Greek name, as Barrett points out ${ }^{1}$, was 'Inoov̂s. God himself could also be described using shepherd imagery 2 . The emperor Tiberius too is reported in Dio as describing his Egyptian subjects as his 'sheep' and in Suetonius he advises the Egyptian prefect on how to be a 'good shepherd'3.

Within the Roman trial narrative the issue of Jesus' kingship suddenly becomes prominent; the word 'king' occurs seven times. The impression is that John wants to focus on the title and to describe exactly in what sense Jesus really was a king.

4) Much more meaningful than kingship for John is the title 'Son of God': the gospel was written with the intention 'that you may believe that Jesus is the Christ, the Son of God' (20:31). It is possible that 'Son of God' was a messianic title based on the OT coronation formula where Yahweh calls the messiah his 'son'4. But for John's readers the title has a much deeper significances. The title primarily shows the unique relationship between Jesus and the Father (17:21), a relationship based on mutual love and filial obedience $(5: 19,8: 28,4: 34)$. Jesus shares the functions of the Father in that he too is the judge of all people and the bringer of etemal life (5:17-30); in fact, Jesus reflects the character of the Father so completely that 'to see the Son is to see the Father' (14:9). 'Both moral likeness and essential unity are included'6.

In 19:7 'the Jews' will charge Jesus with 'making himself' the Son of

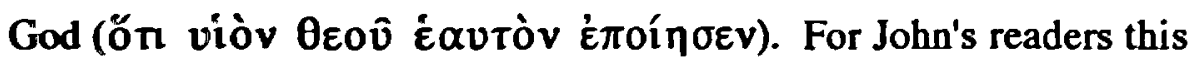

\footnotetext{
'Barret, Gospel, p 369.

${ }^{2} P_{5} 80: 1,23: 1$, Is 40:11. In the NT, 100, the shepherd imagery is used of the sovereign: Rev 2:27; Mi 2:6 (quoung Mic 5:2) sees a shepherd as the messianic ruler.

${ }^{3}$ Doo 57.10.5; Suelonus, Tiberius 32.2.

${ }^{4}$ See Dodd, Imerpretation, p 253; Brown, Gospel, p 88; 2Sam 7:14, Ps 89:27, 2:6-7. This scems to be the way in which it is used in the Synoptics, Dodd p 253 points to Mk 14:61, Mit 16:16.

${ }^{5}$ As Brown bas noted (Gospel, p 1060). Thomas' confession in 20:28 of Jesus as 'God' makes ut unlukely' that the gospel was wniten simply to show that Jesus was the messiah.

GBameth, Gospel, p72.
} 
accusation is completely untrue. Jesus did not make himself the Son of God, nor did he become God's Son through adoption, as was the case with the Israelite Kings, but right from the beginning of time he has existed in this unique relationship with the Father (1:1, 8:58, 17:5). In Brown's words, 'he is not a man who makes himself God, he is the Word of God who has become $\operatorname{man}^{\prime 1}$.

5) John's gospel is unique in that Roman involvement in his narrative comes not only with the handing over to Pilate but at the arrest of Jesus. Whilst this is a purely Jewish affair in the Synoptics ${ }^{2}$, Judas is accompanied in the fourth gospel not only by representatives of 'the Jews' but also by soldiers ( $\sigma \pi \varepsilon i \rho \propto v, 18: 3$ ). If there was any doubt that John is referring to Roman troops here, it is dispelled by the reference to the $\chi \imath \lambda i \alpha \rho \chi 0 \zeta$ in v:18 who is clearly the leader of the $\sigma \pi \varepsilon i \mathrm{p} \alpha$, or cohort. Furthermore, John cannot be using Roman military terms anachronistically to refer to non-Roman troops, as occurs in the $\mathrm{LXX}^{3}$, since he goes on to refer to Jewish officers. So in the Fourth Gospel, Jesus is clearly arrested by Roman troops. Whether John found this detail in a reliable historical tradition or whether he inserted it himself is not important for the flow of the narrative; what is important is that Roman involvement in Jesus' death, according to John, begins right from his arrest.

Nor is this involvement only minimal: John states that a whole orzî $\rho \alpha$ was present. The exact number of men denoted by this term is not entirely clear. $\Sigma \pi \varepsilon i \rho \alpha$ translates the Latin cohors, the tenth part of a legion, or about 600 men. This is consistent with the reference to the $\chi \imath \lambda i \alpha \rho \chi 0 \zeta$ in $v: 18$ which was often used to translate the Latin tribunis militum or commander of a

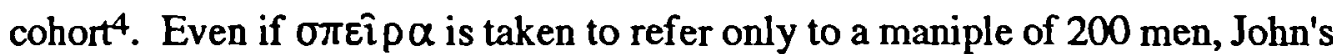
account suggests that a substantial number of troops was involved 5 . These

\footnotetext{
1 Brown, Gospel, p 408.

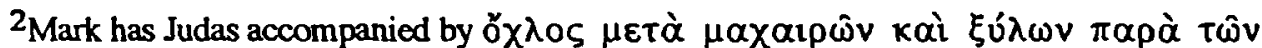

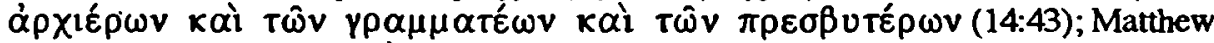
describes the crowd as $\pi 0 \lambda v \zeta$ and omits the reference to scribes (26:47); in Luke it is the

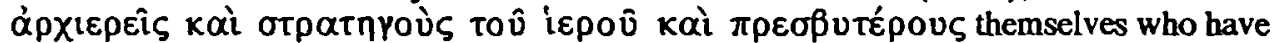
come to arrest Jesus (22:52).

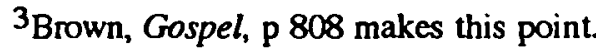

4 In times of peace, however, the governor had only auxilliary troops, drawn from non-Jewish residents, at his disposal; this was the situation in Palestine until Vespasian (Schirer, History, vol I (rev), p 362). Their infantry was divided into cohorts varying from 500-1000 men.

SHistorically, Winter, who thinks that Roman troops were involved in Jesus' arrest, suggests that these figures would be far too high and thinks it more likely that Jesus was arrested by a
} 
come out to arrest Jesus with ö $\pi \lambda$ ov in 18:3, obviously expecting resistance from either Jesus or his followers 1 .

Leaving aside the historicity of this scene, what John portrays on a dramatic-literary level is a fairly large military operation involved in the arrest of Jesus. John's readers would surely know that these Roman troops could only have been placed at the disposal of the Jewish leadership by the prefect himself. Although John has not actually recorded that 'the Jews' have enlisted the help of the Roman prefect, his readers could assume it, not only from the account of the arrest, but also from the Jewish plot in chapter 11 where the chief priests and Pharisees express their fear that the Romans will take severe measures against Jesus' increasing popularity (11:48). John's account, then, suggests that Pilate had already become involved in the plot against Jesus prior to his arrest.

6) John's description of this scene illustrates another point which will be highlighted later in the trial: the Johannine Jesus is perfectly in control of the situation and goes willingly to his fate. This has been prepared for in the Good Shepherd discourse in chapter 10 , a chapter which is of great importance for understanding the Roman trial narrative and one which will be returned to at many points in the following discussion. In 10:11 Jesus says 'the good shepherd lays down his life for the sheep'; in v:14 he says that he is the good shepherd and continues: 'I lay down my life, that I may take it again. No one takes it from me, but I lay it down of my own accord. I have power to lay it down, and I have power to take it again (vv:7-8). Faced with Jesus' revelation

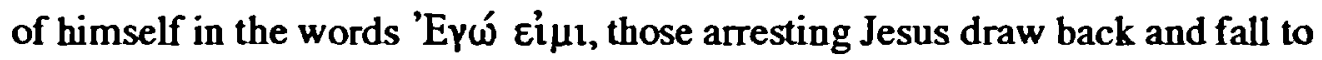
the ground (18:6). Those acting with the authority of 'the world' have no power over Jesus.

7) The hostility between John's community and the synagogue expresses itself most forcibly in the author's presentation of 'the Jews'. Although on occasion this term may be used neutrally ${ }^{2}$, it is much more frequently used

decurio and ten men (Trial, p 29). If there is any accuracy to the report in Acts 23:23, however, the Romans may have occasionally used disproportionately large numbers of men. I Those who arrest Jesus in the Synopucs are similarly armed, Mk 14:43, Mt:47, Lk 22:52 ${ }^{2} E_{\text {g. 4 }}$ 4:22, 8:31 and 11:19. 
perjoratively of Jesus' opponents who are hostile to him and his message ${ }^{1}$. They murmur at Jesus' words (6:41), are unbelieving (9:18), want to put believers out of the synagogue (9:22) and seek to kill Jesus $(5: 16,18,7: 1$, 10:31 and 11:8). In 8:44 Jesus tells 'the Jews' that they are of their father the devil and that their will is to do his desires. This extreme hostility derives from one of the most striking literary features of John's gospel, its existential dualism. The Jews' are those who reject Jesus in contrast to those who believe in him. John has a wide range of dualistic symbols which he uses to contrast those who believe with those who do not. Continually throughout the gospel Jesus or the evangelist posit two alternatives: for example those who receive the light/ those who do not (1:11-12); those who are born of the Spirit/ those who are born of the flesh (3:6), he who does what is evil/ he who does what is true (3:20-21); he who is of God/ he who is not $(8: 47)^{2}$. In a person's response to Jesus there is no room in Johannine thought for a third category of neutrality; one must decide either to accept the revelation or not.

Those who do not accept Jesus' revelation are 'of the world', part of the evil realm in opposition to Jesus ${ }^{3}$. The world hates believers $(7: 7,15: 8)$, rejoices in Jesus' suffering (16:20) and is ruled by Satan (12:31, 14:30). Jesus and believers, however, are 'not of the world' $(8: 23,15: 19,17: 14)$, they are 'from above' $(3: 3,7)$.

Two of these dualistic ideas have a particular bearing on the portrayal of Pilate: they are the concepts of 'truth' and 'hearing'.

a) The importance of the term 'truth' within the thought of the fourth evangelist is clearly recognizable from the occurrence of the noun $\alpha \lambda \eta^{\prime} \theta \varepsilon 1 \alpha$ and its two related adjectives $\dot{\alpha} \lambda \eta \theta \hat{\eta} \zeta$ (implying 'true despite appearances') and $\alpha \dot{\lambda} \eta \theta_{\imath} v o ́ \varsigma$ (implying 'the only real') throughout Johannine literature ${ }^{4}$. At times John's use of these words seems to denote simply that which is in accordance with the facts; that is, the opposite to falsehood or deceit 5 . In other places, however, $\dot{\alpha} \lambda \hat{\eta} \theta \varepsilon \imath \alpha$ and its related adjectives seem to contain a deeper

\footnotetext{
1For a full discussion of John's use of 'the Jews' see von Wahlde, 'Johannine', pp 33-60; in common with the majority of other scholars, he suggests that 'the Jews' virtually al ways refer to the religious authorities (pp 45-46).

2Also 12:25, 14:23-24, 15:5-6.

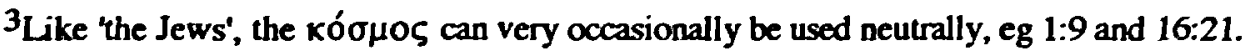

4 Out of the 163 uses of these terms in the NT, 85 are found in John's gospel or the epistles. For more detailed figures see Brown, Gospel, pp 499-501, the definitions of the adjectives are also taken from Brown.
}

${ }^{5} E_{g} 4: 18,37,10: 41,16: 7$. This is also the case with phrases connected with witness or testumony within the gospel, eg 5:31f, and the authorial asides in 19:35 and 21:24 - his witness is true'. 
meaning. God himself can be described as 'true' or 'truth' as at 3:33 - 'God is true' - 7:28, 8:26, 17:3 and 1Jn 5:20. The evangelist means not so much that God is faithful and steadfast but that he represents the ultimate, divine reality ${ }^{1}$. Since Jesus and God are one in Johannine thought ${ }^{2}$, Jesus not only bears witness to 'the truth', ie $\operatorname{God}^{3}$, and is the means by which grace and truth are conveyed to mankind ( $1: 17$ ), but he is that truth, expressed most powerfully by the phrase 'I am the way, the truth and the life' $(14: 6)^{4}$.

'A $A$ ń $\theta \varepsilon \iota \alpha$ characterizes the heavenly realm above, in opposition to what is 'from below' or 'of the flesh'. Jesus can claim to be the true food or true drink in that he provides real food and real drink which lead to eternal life, whilst other forms of food and drink cannot. This involves both the idea of truth as revelation and truth as that which is opposed to what is false.

John's gospel shares with Hellenistic philosophy the conviction that divine reality, represented by God's $\alpha \lambda \eta^{\prime} \theta \varepsilon \imath \alpha$, is in opposition to the Kó $\sigma \mu \circ$ which lies in the power of the devil (12:31, 1Jn 5:19), a murderer who knows nothing of the truth because there is no truth in him (8:44-46). But he differs radically in that God sends his only son, who is himself the $\alpha \lambda \eta^{\prime} \theta \varepsilon 1 \alpha$, in order to save the kó $\sigma \mu \circ \varsigma$ by his revelation of himself and the Father $(3: 16-21)^{5}$. Those who accept this revelation are 'of the truth'.

b) The concept of hearing with understanding is another important Johannine theme which occurs in the Roman trial narrative. $\alpha$ kov $\omega+$ genitive is often used in John not simply with the sense of hearing what is being said, but with the deeper meaning of hearing and therefore believing6. The construction is particularly prevalent in chapter 10 . There Jesus' sheep do not 'hear' the voices of the thieves and robbers who come to steal, kill and destroy

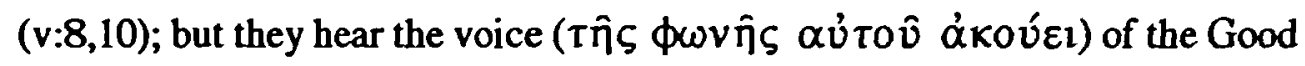
Shepherd (10:3), both his own here (v:14) and his other sheep from a different

\footnotetext{
${ }^{1}$ For scholarly discussions on the background to the term 'truth' in John see Dodd, Interpretation, pp 170-180; Bultmann, TWNTE I, pp 232f; Piper, Truth', pp 713-717; de la Potterie, L'arriere-fond'; and particularly Thistleton in NIDNIT, vol 3, pp 874-902.

${ }^{2} \mathrm{Eg} 1: 1,10: 30,38,16: 15,17: 1,21$.

${ }^{3} \mathrm{Eg}$ 8:13-17, 40, 16:7, $18: 37$.

${ }^{4}$ See also 1:14, 5:33.

5Piper, Truth', pp 713-717 makes the same point. The important connection between $\dot{\alpha} \lambda \dot{\eta} \theta \varepsilon 1 \alpha$ and $k 0 \sigma \mu O \varsigma$ can be inferred from the fact that two thirds of the references to $\dot{\alpha} \lambda \eta^{\prime} \theta \varepsilon 1 \alpha$ in the Johannine writings occur within passages which also deal with the kó $\sigma \mu \circ$ $1: 14,3: 21,8: 44-46,14: 17,15: 26,16: 13,17: 15-19,18: 37$, 1Jn 3:18, 19, 4:6, 5:7.

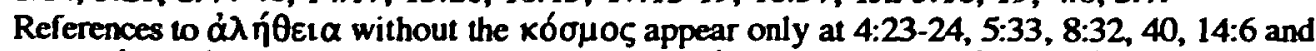

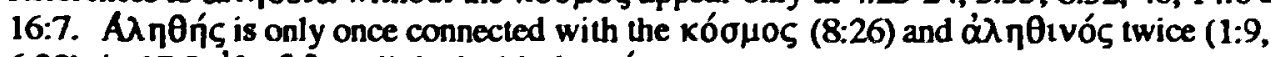
6:32), in 17:8 $\dot{\alpha} \lambda \eta \theta \hat{\omega} \zeta$ is linked with the kó $\mu_{\mu \circ}$

${ }^{6} E_{\mathrm{g}} 5: 24,25,28,8: 40,47,10: 41$.
} 
fold (v:16). Jesus' own are those who hear with understanding and they will have eternal life.

Later in this same chapter Jesus' words cause a division among 'the Jews'; those in 10:20 are against him and accuse him of having a demon and being mad. But the important fact about their statement, as far as the parallels with the trial narrative are concerned, is that their fundamental lack of

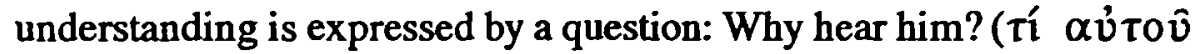

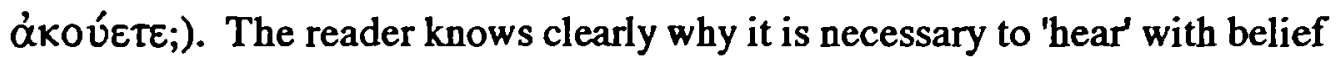
and understanding and what the rewards of that will be, but Jesus' Jewish opponents here represent the hostile 'world' who not only do not hear Jesus but cannot even see the need to hear him.

\section{The Characterization of Pilate}

The general consensus amongst commentators is that John's Pilate is a weak, vacillating figure, running between Jesus and 'the Jews' in a vain attempt to release Jesus and finally capitulating before the threats of the people he is supposed to govern. Three times he proclaims Jesus' innocence and yet he does not have the strength of character to oppose the will of 'the Jews'. Brown sees Pilate as 'typical ... of the many honest, well-disposed men who would try to adopt a middle position in a struggle that is total', his behaviour 'illustrates how a person who refuses decisions is led to tragedy'1. R.A. Culpepper too, in his literary investigation of John's gospel, writes 'As in the other gospels, Pilate is coerced into authorising Jesus' death'2.

Yet even commentators who hold this view have to admit several difficulties. Barrett, for example, sees Pilate's repeated ironic references to Jesus as 'the King of the Jews' as more calculated to embitter 'the Jews' than to secure Jesus' release ${ }^{3}$. No reasons are given for Pilate's scourging of Jesus in the middle of the trial and Brown is forced to conclude that 'while his intentions are good, Pilate's sense of justice becomes more and more warped'4. In the final scene, not only does Pilate's goading lead 'the Jews' to reject their

\footnotetext{
${ }^{1}$ Brown, Gospel, p 864. Similar views are expressed by Barrett, Lindars and Morris in their commentaries.

2 Culpepper, Anatomy, p 142.

${ }^{3}$ Barreth, Gospel, p 539. Culpepper also notes that this reference 'only baits their (ie the Jews') hostility', Anatomy, p 142.

${ }^{4}$ Brown, Gospel, p 889.
} 
nationalist hopes, but they unconditionally accept the kingship of Caesar; Pilate has therefore, in a worldly sense, emerged as the victor.

A recent study by $D$. Rensberger has challenged this usual 'weak' picture of Pilate, suggesting that the Johannine Pilate is to be read instead as a 'strong' character: 'the kingship of Caesar has a cruel advocate in Pilate, who spurns both the sovereignty of Israel and the royal witness to truth'1.

Rensberger's study of Pilate, however, is short (only four pages), and in this chapter I hope to show that his conclusions are basically on the right lines. Pilate in John's gospel is not an impotent, well-disposed governor but, like 'the Jews', he is a representative of the hostile world which rejects Jesus. He serves an important apologetic purpose in his three-fold declaration of Jesus' innocence; yet even these declarations stem from his assumption of the utter ridiculousness of Jesus' messianic claims. Although he once feels a certain amount of superstitious fear, the dominant attitude of the Johannine Pilate throughout the trial narrative is one of mockery, directed at 'the Jews', their nationalistic hopes and the prisoner himself.

\section{The Roman Trial}

Scene I (18:28-32)

Without having narrated anything of the proceedings before Caiaphas, John writes that Jesus is led, presumably by 'the Jews', to the $\pi \rho \alpha \imath \tau \omega$ prov, the Jerusalem residence of the governor during the feast. 'The Jews' did not enter the praetorium 'so that they might not be defiled, but might eat the passover'2. On a literary-dramatic level, the evangelist has provided a reason why 'the Jews' must remain outside, thus the action will take place on two

\footnotetext{
${ }^{1}$ Rensberger, Johannine, p 98.

${ }^{2}$ The historicity of this phrase and exactly what kind of impurity John means have been frequently discussed by scholars. See the discussions in the commentaries, especially Barrett and Brown.

Millar, Reflections, argues that John's account is closer to the historical context of Jesus' ministry and execution, ie the 'real world' of first century Palestine, than the Synoptics. An important factor in this is the prominence give to the passover in John's version. The writings of Josephus give some indication of the status of this feast, the most important of the annual festivals, and the underlying Jewish beliefs about the sanctity of the festival. John's account, more so than any of the others, seems to de dominated by the passover. The approach of the festival dictates the way in which the story will unfold, both in terms of the timing of events (ie Jesus is executed before the passover) and the conduct and attitudes of the Jewish hierarchy, pp 377-379. Although Millar argues that this does not prove that John's account is more historical (it could after all be no more than convincing fiction), it does make John's account more historically probable than any of the others, $\mathrm{p} 376$.
} 
stages; 'the Jews' are outside whilst Jesus has been led inside. Pilate is to be the link between the two.

Pilate is introduced abruptly with no introduction; presumably he was familiar to John's readers from tradition 1 . In v:29 he shows a great deal of tact and courtesy towards 'the Jews': because of their religious sensibilities he comes out of the praetorium to speak to them. After the involvement of Roman troops at the arrest, Pilate was probably expecting the delegation ${ }^{2}$. John gives the proceedings an air of formality and so begins with the judge asking the accusers for the charge ${ }^{3}$ : 'What accusation do you bring against this man?'. He may be asking for a more precise formulation of the charges against the prisoner after the preliminary hearing before Annas in 18:19-23.

'The Jews' appear to be taken aback by Pilate's question and it is difficult not to hear a tone of insolence in their reply: 'If this man were not an evildoer we would not have handed him over'4. Brown suggests that this impudence would not be too unexpected if 'the Jews' had acted with Pilate's backing in the arrest of Jesus and naturally enough expected the governor to try their prisoner 5 .

Pilate's response and the subsequent Jewish reply have been interpreted in several different ways. Pilate says: Take him yourselves and judge him by your own law', 'the Jews' reply: 'It is not lawful for us to put any man to death 6 . The question really revolves around whether Pilate is being serious here or cynical. If he is understood seriously, it could be argued that Pilate does not know the precise charge at this point: annoyed at the insolence of 'the Jews', Pilate tells them to see to Jesus' trial themselves, not realising that he is charged with a capital crime. The reply of 'the Jews' then is a round-about way of indicating that they want him executed, which they are powerless to do. This would make sense if it were not for Roman involvement in Jesus' arrest: surely Pilate would realize that 'the Jews' had only appealed for Roman aid because they wanted Jesus executed. Besides, John's readers would not expect a

\footnotetext{
${ }^{1}$ Barabbas is similarly brought into the story in 18:39 with no introduction, though an explanatory note is inserted in v:40; John assumes that his audience are familiar with the main characteis in the drama.

2This possibility is also voiced by Brown, Gospel, p 866.

${ }^{3}$ Sherwin-White, Roman, p 17.

${ }^{4}$ Brown, Gospel, p 866, Barrett describes it as 'extraordinary and almost incredible impudence', Gospel, p 533.

SBrown, Gospel, p 866.

6 On the compelency of Jewish courts to execute criminals see chapter 1. Millar, Reflections, suggests that this is to be understood not as an allusion to a Roman ban on Jews carrying out executuons but as a Jewish law not allowing a capital trial the day before a Sabbath or festival, p 375; cf mSanh 4.1 which, though later, may reflect the same ban.
} 
provincial governor to allow a disturber of the peace to pass so easily out of his hands ${ }^{1}$, especially at passover time.

It may be better then to interpret the words of the Johannine Pilate cynically. He has sent Roman soldiers out against Jesus, gone outside the praetorium to meet the Jewish delegation and attempted to instigate formal procedures against the defendant, only to be met with insolence. His words may thus be a way of reminding 'the Jews' that he is the judge and without him they are not in any position to condemn Jesus. Pilate knows that 'the Jews' have no power to execute but wants to humiliate them by making them admit it. The Jews' cannot condemn anyone by their own law and so their answer is a grudging reflection of this. Pilate is therefore mocking Jewish impotence concerning capital jurisdiction and also asserting his position as the only one able to judge Jesus. This theme of judicial authority will reappear in scene vi when Jesus tells Pilate that the authority which he thinks is his is ultimately derived from God (19:11).

Scene II (18:33-38a)

Pilate goes inside the praetorium and summons Jesus, asking $\sum \dot{v} \varepsilon \hat{i} \quad \dot{0}$

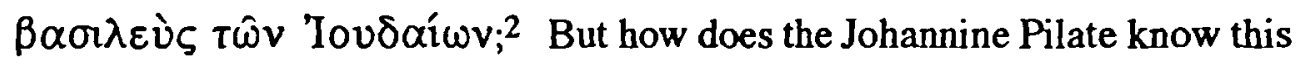
charge? The Jews' have told him only that Jesus is an 'evildoer'. Unless the evangelist is unthinkingly reproducing tradition, Pilate's question here supports the view that he already knew something of the prisoner before the trial; perhaps that he had lent military aid to 'the Jews' in order to arrest Jesus precisely because they had warned him that Jesus was some kind of messianic pretender $^{3}$.

To Pilate's straight-forward question, Jesus answers 'Do you say this of your own accord, or did others say it to you?'; Jesus seems to be meaning 'Have you, as a representative of Roman law and order, seen me engaging in seditious activity and brought this charge against me, or have others suggested it to you?'

Pilate's reply clearly indicates that the charge has been formed by Jesus'

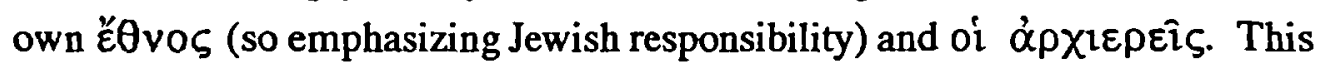
is the first opportunity Pilate has had to try the prisoner and he is acting on a

\footnotetext{
1 Barrett, Gospel, p 533.

2 This charge is exactly the same in all the gospels and appears to have been derived from tradition: Mk 15:2, Mt 27:11 (where it is again introduced abruptly), $L k 23: 3$ (in response to the Jewish accusations).

${ }^{3}$ On the title 'King of the Jews' see the chapter on Pilate in Mark.
} 
charge suggested to him by 'the Jews'. Pilate's reaction 'Am I a Jew?'; emphasizes that the charge is Jewish and at the same time distances Pilate from 'the Jews' and their allegations in that $\mu$ í $\tau 1$ expects a negative answer: Ethnically, Pilate is certainly not a Jew, and is only acting on information given to him by others. His sharp reply may also betray an undertone of Roman contempt for the Jews ${ }^{1}$. The Roman governor in John's narrative has no prior knowledge of Jesus' activity other that what 'the Jews' have told him and so goes on to ask: 'What have you done?' (v:35).

Jesus completely ignores this last question and launches into a description of his kingdom, using typically Johannine terms (eg $8: 23,17: 11,14,16)^{2}$. His words stress that his kingdom is not a worldly political one, as the lack of military activity by his followers suggests; iं $\gamma \omega v i \zeta$ ovTo is imperfect continuous, that is, his followers would be fighting now, not just at the arrest ${ }^{3}$. As Barrett puts it, 'Kings of this world naturally fight for supremacy; that Jesus and his followers do not do so shows that his kingdom is of a different order'4.

Pilate refuses to enter into a discussion on the exact definition of Jesus' kingdom and steers the conversation back to the central theme of Jesus' kingship with the words: 'So you are a King?'5. The governor wants a definite statement from Jesus, is he a king or is he not? It may be significant that Pilate has dropped the reference to 'the Jews', possibly since Jesus' words in v:36 show them to be his enemies. Again, Jesus refuses to give a definite answer and replies: 'You say that I am'. He then goes on to explain that his central role is not one of kingship but, in typical Johannine language, to bear witness to the truth (v:37)6. Everyone who is 'of the truth', Jesus states, hears his voice (v:37). In reply, Pilate utters his famous question, 'What is truth?'.

How did the author of the Fourth Gospel expect his readers/hearers to interpret this? Is he simply using his frequent motif of misunderstanding here? Throughout the Fourth Gospel hostile, neutral and friendly characters show themselves unable to understand Jesus' words. A particularly clear example of

\footnotetext{
1 Brown, Gospel, p 852.

2 Unlike the synoptic accounts, references to the 'kingdom' are very rare in John. Previously $\beta \alpha \sigma \lambda \lambda \varepsilon i \alpha$ tố $\Theta \varepsilon o \hat{~ h a s ~ b e e n ~ r e f e r r e d ~ t o ~ i n ~ 3: 3,5 ; ~ h e r e ~ i t ~ i s ~ n o t ~ G o d ' s ~ k i n g d o m ~ b u t ~ J e s u s ', ~}$ although 17:10 shows that what is God's is also Jesus'.

3 Morris, Gospel, p 769; Dodd, History, p 112.

4 Barrett, Gospel, p 537.

5 Barrett notes that the argumentative particle ov̉xov̂v sceks a definite answer and translates: 'Very well, so you are a King?' Gospel, p 537.

${ }^{6}$ Cf 3:21, 14:17, 15:26, 16:13, 17:17,19,
} 
this is Nicodemus in 3:4 who does not understand the significance of being born $\alpha^{\prime} v \omega \theta \varepsilon v$ and interprets Jesus' words literally as physical birth ${ }^{1}$. In the same way, Pilate seems to be clutching at terms which he understands without understanding the sense in which Jesus is using them. So, earlier, he seized on Jesus' use of 'kingdom' and asked if he was a king, and here he seizes on the word 'truth' without any understanding of what it involves. Yet the importance of the term 'truth' in Johannine thought suggests that Pilate's words reveal more than simple misunderstanding here.

That this is not a serious philosophical speculation is made apparent by the very next phrase: 'After he had said this, he went out to the Jews again'; the Roman governor does not wait for an answer. Nor is it primarily an expression of irritation at a prisoner who persists in countering the governor's straightforward questions with references to other-worldliness and truth, though there may be something of this on a purely literary level ${ }^{2}$. Instead, in exactly the same way in which Jesus' Jewish opponents in 10:20 showed that they did not belong to Jesus' sheep by the question 'Why hear him?', Pilate shows that he is

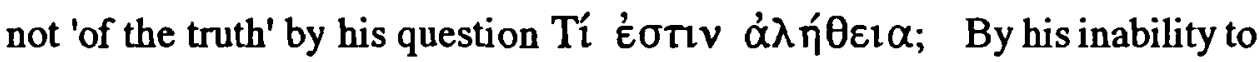
hear Jesus with understanding and belief and his failure to recognize the truth, Pilate is not of God (8:47) and so, like 'the Jews', he is part of the unbelieving world which rejects Jesus. Furthermore, even the question is wrongly put. $\dot{\alpha} \lambda \eta^{\prime} \theta \varepsilon \imath \alpha$ takes on a personal character in John, denoting the divine reality of the Father and the Son. So the appropriate question is not simply 'What is truth?' but 'Who is truth?'. The Roman governor cannot see that 'the truth' is personified in the prisoner before him.

In 18:37 Jesus issued a challenge to the representative of the Roman Empire: will he respond to the truth? By his question he showed that he would not accept Jesus, and so not only Pilate but also the empire which he represents are, in Johannine thought, part of the unbelieving 'world'. Pilate has now answered his first question 'Am I a Jew?': the answer is 'yes'; he has joined the unbelieving world symbolized most starkly in Johannine thought by 'the Jews' in rejecting Jesus ${ }^{3}$.

\footnotetext{
1 The Samaritan woman too does not understand the significance of 'living water' (4:11). In 12:34 the crowd does not understand who the 'son of man' is, in 14:5 the disciple Thomas takes Jesus' words too literally. Other examples are 7:35, 8:22, 10:6, 11:12f ,12:16, 13:7, 14:8, 16:17-18 (the failure of Mary and the disciples to recognize Jesus after the resurrection may also be part of this general motif, 20:14, 21:4).

${ }^{2}$ Stibbe, Storyteller, p 107.

3I cannot agree with Bultmann who regards Pilate as the representative of the 'state' abstracted from 'the world'. He writes: 'the state is able to adopt the point of view that the question about $\alpha \lambda r^{\prime} \theta e i \alpha$ has nothing to do with it. Instead of refusal or recognition of the truth, Bultmann asserts that in this scene 'the state' chooses neutrality. It remains on the outside: it
} 
Scene III $(18: 38 b-40)$

This short scene is extremely difficult to make sense of. Pilate goes outside again to where 'the Jews' are waiting and declares that he finds no guilt in the prisoner, but instead of simply offering to release Jesus there and then, he alludes to a Jewish custom by which he should release one prisoner at passover. He then asks 'the Jews' if they want him to release 'the king of the Jews' to them, to which they reply that they want Barabbas released instead.

Two problems dominate the interpretation of this scene. Firstly, if the Johannine Pilate has genuinely found no guilt in Jesus, why does he not simply bring Jesus out to the waiting Jews and set him free? Why mention an amnesty, an offer which could potentially, and in fact does, have disastrous results in that 'the Jews' take the opportunity to demand the release of another prisoner? Secondly, why does Pilate refer to Jesus as the 'King of the Jews' a title which, certainly in the final scene of the trial narrative, seems to be deliberately mocking Jewish nationalistic hopes?

The simplest solution, of course, is that John found both these elements in the tradition upon which he was dependent. Yet John does not elsewhere seem to go out of his way to add details simply because they are traditional. If he has incorporated the reference to the amnesty ${ }^{1}$ and the designation 'King of the Jews' here, then, it is reasonable to suppose that both make sense within the narrative.

The general view of this scene is that it shows Pilate's weakness. He tells the waiting Jews that he finds no crime in Jesus, but does not have the strength of character to act on his convictions and release the prisoner. Instead, he attempts to release Jesus as part of an amnesty, referring to him as the 'King of the Jews' in order to stir the nationalistic sympathies of his audience. The Jews, however, outwit him and seize the opportunity to demand the release of another prisoner, Barabbas. The defeated prefect retreats into the praetorium

is not of the truth, but nor is it in the same category as 'the Jews', signifying 'the world, Gospel, pp 652-657. There are two strong arguments against this line of approach. First, as pointed out above, Johannine dualism leaves no room for neutrality. Secondly, the earliest Christians did not have the luxury of being able to regard 'the state' as an abstract concept, divorced from 'the world'; for them the state took on very real and concrete proportions - it was the Roman Empire, representatives of which governed their lives and actions and, on occasion, had persecuted them (eg Tacitus, Ann 15:44 of persecution in Rome; in Jn 16:2b and 15:20 it may be the Romans who are actually doing the persecuting). Thus, 'the state' was not an abstract concept which could respond to Jesus' revelation with neutrality but a very real part of the first century world.

1 For historical problems raised by this custom see chapter 1. 
and prepares his next vain attempt to release Jesus - this time by having him flogged and brought out before his enemies.

This characterization of Pilate, however, will not fit the Johannine Pilate encountered so far within John's trial narrative. In this gospel, Pilate is addressing exactly the same Jews - the chief priests and the officers - who handed Jesus over in 18:28f. Whereas in Mark's narrative a crowd has gathered (15:8) and Pilate's words make sense as an attempt to gauge popular support for the messianic claimant brought to him previously by the members of the Sanhedrin (15:1), in John there is no neutral crowd. The audience before the Johannine Pilate is composed of exactly the same people who in $18: 31 \mathrm{~b}$ admitted that they had brought Jesus to Pilate for execution. Surely he cannot now expect these same opponents quietly to acquiesce to Jesus's release? Besides, by putting the offer of release within the context of the amnesty, Pilate's actions appear even more naive and miscalculating. Not only do the chief priests, naturally enough, not want their prisoner released, but they use the opportunity to secure the release of a political activist, a $\lambda \eta \sigma \tau$ j $\varsigma(18: 40)$. Does the Fourth Evangelist really want to portray his Roman prefect as completely miscalculating and ineffectual? How realistic would such a governor be to John's readers, themselves living under the harsh authority of Rome?

Perhaps it would be useful for a moment to understand this scene in a different way; that is, not seeing Pilate's actions as a serious attempt to release Jesus. Certainly John does not say that Pilate wishes to release the prisoner, as he does in 19:12. The Johannine governor says to 'the Jews' I find no crime in him". The $\dot{\varepsilon} \gamma \omega \dot{~ h e r e ~ m a y ~ b e ~ e m p h a t i c ~}{ }^{1}$, or at least it highlights the contrast between Pilate's failure to find any political guilt in Jesus with the political allegations of 'the Jews' who handed him over. He continues: But you have a custom that I should release one man for you at the passover, will you have me release for you the King of the Jews? As noted before, 'King of the Jews' was the Gentile form of 'King of Israel', a term associated with the expected Messiah. John's readers would recognize the significance of the reference to passover here, a celebration of freedom from slavery and oppression in Egypt and a feast at which Messianic expectation might be at its height ${ }^{2}$. In fact, John's readers would presumably realize that it was because of potential

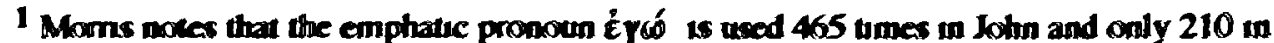
Mbmhew. 104 in Mark and 215 in Luke. This is not the case whb any other pronoun (Coopel, p 133, n. 12) It is used partucularly of ten when John the Bapust speaks, comstrationg buself with lesus $(1.23,26,27,30,31,33,34), p 133$.

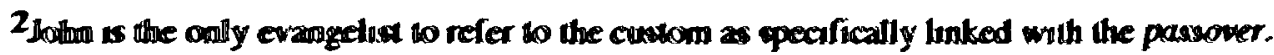


messianic fervour and rioting generally in the crowded city that the Roman prefect was in Jerusalem and not at his normal residence in Caesarea ${ }^{1}$. It is therefore deeply ironic that the Johannine Pilate, as the representative of an occupying pagan administration, is in a position to release the Jewish 'King' at passover. Pilate's words, then, sound more like mockery of Jewish nationalist hopes and an assertion of his power over 'the Jews' than a serious offer to release Jesus. The prefect knows that 'the Jews' want Jesus executed but takes the opportunity to mock their messianic aspirations and, indirectly, the prisoner himself. Precisely this same attitude will reappear in the final scene of the trial. 'The King of the Jews', then, was not just lifted from tradition but used specifically to mock Jewish nationalism.

The evangelist also uses this scene to incriminate Jesus' Jewish opponents further: in the context of the passover, they utterly reject their Messiah. Instead, they expose their nationalist sympathies and ask for Barabbas. The fact that John refers to this prisoner as a $\lambda$ jotrí $\varsigma$ may indicate that he regards such political activists not so much as 'freedom fighters' but as 'brigands' or 'robbers' in the same sense in which Josephus uses the term². Jesus' opponents have therefore rejected the true 'King of the Jews' in favour of a common criminal ${ }^{3}$.

Scene IV (19:1-3)

Taken literally, the active verb $\dot{\varepsilon} \mu \alpha \sigma$tí$\gamma \omega \sigma \varepsilon v$ implies that Pilate scourged Jesus himself. But by the presence of soldiers who mock Jesus in verses 2 and 3 we are surely to understand that it was they, and not the Roman governor, who carried out the scourging. Yet John's use of the active verb in v: 1 clearly shows that Pilate is responsible. John uses the same device again in

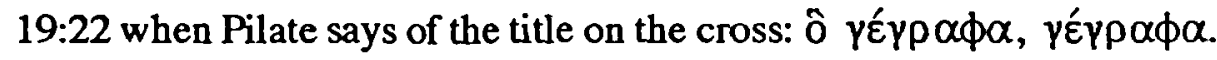

John's readers would surely not assume that the Roman governor had set to

\footnotetext{
${ }_{1}$ A gain, see chapter 1.

${ }^{2}$ See Hengel, Zealots. Josephus 'speaks of $\lambda$ j oraí especially whenever he intends to express his moral condemnation of the opponent' $(\mathrm{p} 43$ ) and he uses 'the word $\lambda \eta \sigma \tau \alpha$ í in order to brand the Zealots as lawless rebels and criminals in the Roman sense and as men who in the end received the punishment they deserved' ( $p$ 45). See especially pp 41-46.

${ }^{3}$ Each of the synoptic gospels explicitly notes that Pilate released Barabbas but John does not. Possibly this is because the whole narrative is reported briefly and the evangelist is not interested in recording the fate of Barabbas. The major point is that 'the Jews' reject Jesus and, by demanding the release of Barabbas, expose their nationalist sympathies. Again, echoes of chapter 10 are present in this scene, see especially the reference to thieves and robbers ( $\lambda$ jJ $\left.\sigma \alpha^{\prime}\right)^{\prime}$ in v:8 who are not heeded by Jesus' sheep.
} 
work and written the titulus himself, but the active verb shows that Pilate takes responsibility for the actions of those under his command.

The word used by John to describe this beating is $\mu \alpha \sigma \tau \imath \gamma o$ of the usual Greek word for 'flogging'1 ; a severe and degrading punishment ${ }^{2}$. Some have seen parallels between Pilate's action here and the offer of the Lukan Pilate to discipline Jesus and then to release him $(\operatorname{Lk} 23: 16,22)^{3}$. But Luke's verb $\pi \alpha_{1} \delta \varepsilon v ́ \omega$ implies a milder beating, intended to 'teach the prisoner a lesson'. John's audience would surely be aware of the distinctions between the different types of Roman beatings. That the flagellation was mistakenly supposed by John and his audience to be a cautionary beating, therefore, seems unlikely.

Scourging was the usual preliminary to crucifixion ${ }^{4}$. But so far in the Johannine narrative, Jesus has not been sentenced; crucifixion is not even mentioned until the next scene, so the flogging cannot be a preliminary to execution 5 . So why does the Johannine Pilate administer such a severe punishment to the prisoner at this stage of the proceedings? The evangelist himself gives no reasons for the prefect's harsh treatment of Jesus and a fuller inquiry will have to wait until Pilate's next appearance in Scene VI.

Subsequent to the flogging, Jesus is mocked by the Roman soldiers ${ }^{6}$. It is possible that in John's presentation the soldiers are not just mocking Jesus as a Hellenistic king generally, but as the emperor. In the Greek-speaking world the emperor was often referred to a $\beta \alpha \sigma \lambda \varepsilon \varepsilon^{\prime} \zeta^{7}$. In Acts 17:7 Jason and some others are accused of 'acting against the decrees of Caesar, saying that there is another King, Jesus'. Besides, as far as the Gentile soldiers were concerned, 'the king of the Jews' was none other than Caesar, as even the chief priests are forced to acknowledge in 19:15. The presence of the purple garment, the

\footnotetext{
${ }^{1}$ Barrett, Gospel, p 539. Mk 15:15, followed by Mt 27:26, uses the Latinized form of the verb $\phi \rho \alpha \gamma \varepsilon \lambda \lambda$ ó $\omega$ (cf Jospehus, War 5.449). John's word $\mu \alpha \sigma \tau$ เ ${ }^{\prime} \omega$ and the word for 'slapped' in v:3, $\rho \alpha \pi i \zeta \omega$, may have been drawn from Is $50: 6$, though the evangelist does not emphasize this connection.

${ }^{2}$ See the chapter on Mark who uses the same word.

${ }^{3}$ Eg Westcoth, Gospel, pp 267 .

${ }^{4}$ See the chapter on Mark for evidence.

${ }^{5}$ Matthew and Mark give the impression that the scourging and mockery take place after the proceedings involving Pilate are completed; the soldiers engage in their malicious jokes apparently without the presence of Pilate (eg Mk 15:16-20). Luke has no mockery at the hands of the Roman soldiers but does record a similar incident at Herod's court (23:11).

6 As usual, John gives no unnecessary details: he does not say how many were involved (Mk 15:16 and Mt 27:27 mention a whole cohort) nor where the incident took place, though from v:5 it appears to be inside the praetorium. The slapping of Jesus by the soldiers underlines the element of mockery in the proceedings (against Meeks, Prophet, p 69 who denies that the soldiers are mocking Jesus). For a fuller discussion of the mockery see the chapter on Mark.

7 Cr Barrett, Gospel, p 543, Brown, Gospel, p 880.
} 
crown, which may represent the imperial laurel wreath, and the greeting of the soldiers all suggest that Jesus is ridiculed here as a mock-emperor.

Scene V(19:4-8)

Presumably Pilate has remained inside throughout the scourging and mockery, in v:4 he goes out to 'the Jews' again. Most commentators regard this as Pilate's second attempt to release Jesus, the first attempt with the amnesty having backfired. Thus the prefect has Jesus scourged and brings him out, still royally bedecked, in a vain attempt to appeal to either the sympathies or nationalistic hopes of the waiting Jews ${ }^{1}$. Accordingly, $\delta ~ \not ै v \theta \rho \omega \pi o \zeta$ is said to express Pilate's pity for the defendant and is translated 'Here is the poor creature' or 'See the poor fellow'2. Or, Meeks suggests on the basis of Zech 6:12, 'Man' may have been an eschatological title in Hellenistic Judaism and Pilate is alluding to this ${ }^{3}$.

Yet again there are problems with a benevolent Pilate wishing to release Jesus. The prefect subjects Jesus to an extremely severe flogging, brings him out in mock kingly regalia before the same Jews who have brought Jesus to him for execution, and expects them now to feel sympathetic towards the prisoner! The Johannine Pilate in this reconstruction lacks any political astuteness or psychological awareness. As Lindars notes: To bring him out now, already arrayed as a laughing-stock, could only invite a ribald and hostile response, the very opposite of the conditions required for a considered judgement of the case' and The motive given, "that you may know that I find no crime in him" ... is extremely lame and scarcely plausible ${ }^{4}$. The chief priests and officers, of course, do not feel sympathy for the prisoner; nor does the sight of the scourged man in the royal robes arouse their nationalistic

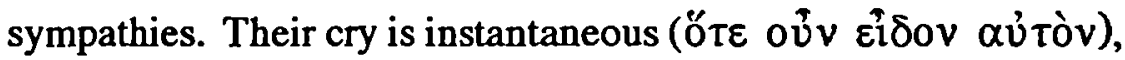

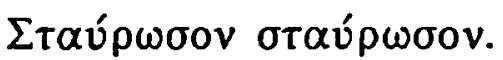

As with the Barabbas scene, it may be better not to try to twist this scene into an attempt by Pilate to release Jesus but simply to take the text at its face

\footnotetext{
${ }^{1}$ See for example, Brown, Gospel, pp 886-889; Westcott, Gospel, pp 267-268; Lightfoot, St John's, p 312; Morris (with reservations), Gospel, p 790.

2 Vicws put forward by Bemard, St John, p 616; Morris, Gospel, p 793; also Stibbe, Storyteller, p 108.

${ }^{3}$ Meeks, Prophet, p 70-71. Brown also favours this interpretation, commenting that Pilate may be presenting Jesus to the people under a messianic title'.

${ }^{4}$ Lindars, Gospel, p 565.
} 
value. Pilate says that he is bringing Jesus out to show that he finds no guilt in Jesus; that is, political guilt: any kingship which Jesus may claim to possess is no threat to the Roman state. Jesus then comes out, scourged and arrayed as the King of the Jews. The point is that Jesus is no threat to Roman law and order because, the Johannine Pilate implies, he is so completely humiliated and despised. 'Behold the man' on Pilate's lips therefore is contemptuous. The scourged prisoner is a parody of Jewish messianic hopes which, 'the Jews' have already shown in Scene III, centre on $\lambda \eta \sigma \tau \alpha i$ and political activists and can only be an embarrassment to 'the Jews'. The Johannine Pilate is mocking not only the Jews and their nationalistic hopes but also the prisoner before him.

But the use of $\alpha v \theta p \omega \pi$ o here may go further. If Jesus was mocked as a pseudo-emperor, or any other 'divine' Hellenistic king, then Pilate's contemptuous use of $\alpha 2 v \theta \rho \omega \pi$ o may be to contrast him further with these rulers. Historically, Tiberius was the emperor during Pilate's prefecture and he, like Augustus, was only deified after his death. However, the majority of scholars agree that the Fourth Gospel was shaped largely during the reign of Domitian (81-96), and this emperor did assume, at least unofficially, divine honours during his lifetime ${ }^{1}$.

To John's readers, probably living in a large Hellenistic city and wellacquainted with the divine claims of their emperor, Pilate's contempt and emphasis that Jesus was only mortal, would stress just how ridiculous the prefect found Jesus' kingly pretensions. The 'King of the Jews' for the Johannine Pilate is the divine emperor; the scourged and mocked 'man' in front of him is only a creature of ridicule. 'The Jews' for their part want nothing to do with this man who parodies their messianic hopes and they cry for crucifixion.

Yet throughout the course of this mockery, Jesus never loses his kingly dignity. The Johannine Pilate may scathingly speak of 'bringing Jesus out',

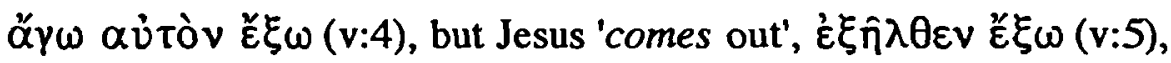
apparently unaided. Although Jesus has been scourged, John makes no references to physical injuries or indignities. Throughout the entire trial

${ }^{1}$ See entry in $O C D, 2$ nd ed, $\mathrm{p} 360$. Also Suetonius, Domitian 13.2, where he writes that the emperor insisted on being referred to as 'dominus et deus noster'. Cassius Dio refers to the same ruler as master and god ( $\delta \varepsilon \sigma \pi o ́ t \eta \zeta,, \theta \varepsilon o ́ \varsigma)$ in 67.4 .7 and 67.13.4. It may also be

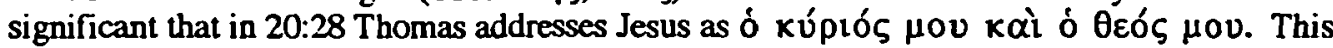
combination occurs in pagan literature (Barrett, Gospel, p 572f) and in the LXX as a translation of YHWH elohim, though, as Brown points out, never in precisely this form (Gospel, p 1047). The usual formula is kúpte, ó $\theta \varepsilon o ́ \varsigma \mu$ ov and the closest to Jn 20:28 is Ps 35:23, 'my God and my Lord'. Rev 4:11 addresses God who, in Johannine thought, is one

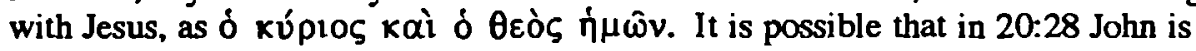
contrasting Jesus with the Roman emperor. it is Jesus and not Domitian who can truly claim this title. 
narrative John's perceptive readers can see that the true kingly qualities of Jesus transcend Pilate's mockery and the insistent demands of 'the Jews' for crucifixion. They may also see a deeper meaning in the contemptuous words of the Johannine prefect: by using 'man', John may be making Pilate unconsciously refer to the 'Son of Man' who is lifted up on the cross and yet by that very act is exalted in glory $(3: 14-15,8: 28,12: 23,34,13: 31)^{1}$. Paradoxically, the hour of the Son of Man's glorification $(12: 23,13: 31)$ is when he is most mocked and humiliated by 'the world'.

The Johannine Pilate within the narrative, however, knows nothing of these deeper truths. The chief priests and officers cry for crucifixion and Pilate replies: 'Take him yourselves and crucify him'. Schlier took this as a serious suggestion, indicating that Pilate's control was so far gone that he was willing to allow 'the Jews' to crucify a man whom he had found innocent ${ }^{2}$. But two features indicate that this offer is not to be taken seriously. Firstly, although there is some evidence to suggest that the Jews may have used crucifixion as a standard punitive measure at certain times throughout their history ${ }^{3}$, John has 'the Jews' inform Pilate (and the readers) in 18:31 that they do not have the right to inflict the death penalty in this particular case ${ }^{4}$. Secondly, 'the Jews' themselves in v:7 do not take the prefect's words seriously; in fact, quite the reverse, they remount the attack with a religious charge. Brown sees the governor's words as 'an expression of Pilate's exasperation's whilst Morris suggests that they are 'the sudden wild statement of a man who is goaded into speaking unreasonably'6 . But since Pilate's tone has previously been one of mockery, it may be better to interpret this verse too in the same light.

The Roman prefect is reminding 'the Jews' that they have no right to pass a capital sentence upon the prisoner, whether by crucifixion or any other means. As in Scene I, he is mocking their status as occupied people and

\footnotetext{
${ }^{1}$ The Aramaic barnasa, which is literally translated 'son of man', can mean simply 'man'. See Barrett, Gospel, p 541, Lindars, Gospel, p 566. Bultmann suggests that the term stresses the

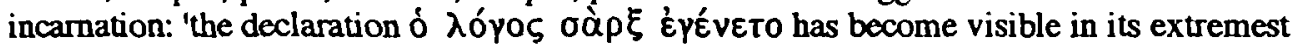
consequences', Gospel, p 659.

2 Schlier, 'Jesus', pp 56-74.

${ }^{3}$ In a reconstruction of col xviv of the Temple Scroll, which comments on Dt 21:18-21 and the execution of 800 Jews by Alexander Jannaeus, Yadin suggests this document recognizes that crucifixion could be used as a Jewish form of execution for specific political crimes, 'Pesher Nahum', pp 1-12. See also Ford, 'Crucify him', pp 275-278; Bammel, 'Crucifixion', pp 162-165; Fitzmyer, 'Crucifixion', pp 493-513. Against Yadin is Baumgarten, Temple Scroll', pp 472-481, who thinks that the scroll refers to hanging.

${ }^{4}$ A gain, see Millar, Reflections, for possible Jewish limitations to the right of capital punishment in this particular case ( $\mathrm{p} 375$ ).

5 Brown, Gospel, p 877.

6 Morris, Gospel, p 795.
} 
asserting his own authority over them ${ }^{1}$. His subsequent 'For I find no crime in him' again shows that Pilate sees Jesus more as a creature to be despised and mocked than any serious threat to Rome.

In the face of this mockery, Jesus' opponents within the Johannine narrative change their tactics, now bringing a religious charge: 'We have a law, and by that law he ought to die, because he has made himself the son of God' $(19: 7)^{2}$.

The effect of this charge on Pilate is considerable: in v: 8 the evangelist tells us that he was/became $\mu \hat{\alpha} \lambda \lambda$ ov $\dot{\phi} \beta \hat{\eta} \theta \eta$. Some have taken this as meaning 'more afraid' and have therefore been forced to assume that John is abbreviating a longer account or have looked for indications of fear in Pilate's previous behaviour ${ }^{3}$. Not only is this grammatically unnecessary as the comparative here has the force of an elative 4 but, as already pointed out, the prefect has hitherto shown no signs of fear. $\mu \hat{\alpha} \lambda \lambda$ ov $\dot{\phi} \phi \beta \tilde{\eta} \theta \eta$ then appears

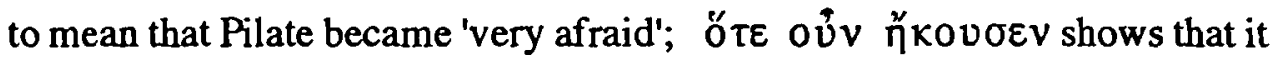
was the words of 'the Jews' which produced this sudden great fear. No reasons are given by the evangelist to explain why the scathing, mocking prefect, who was previously so sure of his position and authority over 'the Jews', should suddenly be afraid. It is reasonable to suppose, however, that it is based on superstition. Greek and Roman mythology has numerous examples of gods taking on human form or begetting children: Homer refers to the sons of Zeus or other gods as the/a 'son of god'5; Heracles could refer to Zeus as 'father'6. Compare also the experiences of Paul and Barnabas in Lystra, Acts 14:8-18. To a Hellenistic mind, the allegation could suggest that Jesus was 'a divine man with magical powers of occult origin'?. Also, since 'the Jews' have already exposed their nationalistic hopes in Scene III and shown that their political allegations against Jesus have no substance, the Johannine Pilate may therefore realize that the charge of 'making himself the son of God' is the real Jewish charge against Jesus and is not to be taken lightly.

In one sense, the two Jewish charges are not entirely distinct. The first charge of kingship alleged that Jesus was setting himself up in opposition to

\footnotetext{
${ }^{1}$ So Cassidy, John's, p 46.

${ }^{2}$ This charge was also prominent at 10:22-39, the nearest parallel in John to the Jewish trial in the synoptics. Now that Jesus' 'hour' has arrived, the Jewish charge reappears.

${ }^{3}$ Eg Bultmann, Gospel, p 511.

4 Cf Brown, Gospel, p 877; Barrett, Gospel, p 524, and Lindars, Gospel, p 567.

5lliad 5.683, Odyssey 11.568.

${ }^{6}$ See Epictetus, Dissertationes 2.16.44; 3.24.14f.

7 Brown, Gospel, p 877-878.
} 
Roman rule and the emperor. With the assassination of Julius Caesar in $44 \mathrm{BC}$, Octavian announced himself as divi filius or 'Son of God'; this title was retained by subsequent emperors. This second charge too then implies that Jesus is usurping the prerogatives of the emperor. The superstitious fear instilled in the Johannine Pilate, however, suggests that he understands the charge in a religious, not a political sense.

Scene VI(19:9-11)

Accordingly, Pilate enters the praetorium again (presumably taking Jesus inside too) and asks the prisoner 'Where are you form?' a question which might follow on naturally from the charge that he was making himself the son of God ${ }^{1}$. The reader knows that Jesus is from the Father, or from above ${ }^{2}$, but if Nicodemus did not understand this then the Roman governor is even less likely to. Jesus therefore remains silent. This silence seems to exasperate Pilate who asks: 'Do you not know that I have power to release you, and power to crucify you?' (v:10). The theme of the govemor's authority, which seems to have been present implicitly in the previous narrative reappears explicitly in this scene. Here Pilate is using $\dot{\varepsilon} \xi$ ov ó $\alpha$, with the possibility of release or crucifixion which it involves, to force Jesus to answer his previous question. Instead, Jesus turns on the governor's use of $\dot{\varepsilon} \xi o v o ̛$ ó, stating that his $\dot{\varepsilon} \xi$ ov ói $\alpha$ comes not from the emperor, as Pilate believes, but $\alpha$ $v \omega \theta \varepsilon v^{3}$. The governor would have no power whatsoever (the ov $\delta \varepsilon \mu$ í $\alpha v$ is emphatic) if it had not come from God4. Pilate's double use of $\bar{\xi} \xi$ ovoí $\alpha$ is reminiscent of 10:17-18. There Jesus says that he has the power to lay down his life and the power to take it up again, a charge which he has received from the Father. It is clear that it is not the Roman governor who has the power/authority to execute Jesus but Jesus himself who lays down his own life. Pilate's authority

\footnotetext{
${ }^{1}$ A simılar question is addressed to Jesus in $L k 23: 6$ where the Lukan Pilate inquires to which province Jesus belongs before sending hum to Herod.

${ }^{2}$ Cf 3:8, 7:27f, 8:14, 9:29.

3 See the discourse with Nicodemus 3:3,7. A similar idea is expressed in Rom 13:3f.

${ }^{4}$ The same idea is expressed by John the Baptist in 3:27 when he says that no one can recerve anything except what is given him from heaven. As Bartet points out, 19:11 is the Johannupe literary device of misunderstanding in reverse; usually a theological word is taken in a literal sense by Jesus' hearers; here, Pilate's use of the word ķ̇ovori $\alpha$ in a secular sense is transformed by Jesus into the absolute '̇ं ${ }^{\circ}$ ov ó $\alpha$ of God (Gospel, p 542).
} 
ultimately derives from God; thus 'the crucifixion does not contravene the authority of God but lies within its purpose'1.

Jesus goes on to say: Therefore he who delivered me to you has the greater sin'. To whom is John referring here? Due to the surprisingly frequent use of $\pi \alpha \rho \alpha \delta i \delta \omega \mu l$ to describe the handing over or betrayal of Jesus by Judas in the Fourth Gospel and the singular participle, Barrett thinks that Judas is again referred to here 2 . But it is 'the Jews' who hand Jesus over to Pilate and $\pi \alpha \rho \alpha \delta i \delta \omega \mu \mathrm{l}$ is twice used of their actions (18:30,35). Also, it is difficult to see why Jesus should launch into an attack on Judas at this point. It seems more likely that the singular participle is to be taken as generic, meaning that the one who betrays the messiah is more guilty than the one who judges him. In this case, it probably refers to 'the Jews', or at least to the chief priests and others who have actually handed Jesus over ${ }^{3}$. Primary guilt for Jesus' execution therefore, according to John, rests with 'the Jews', but this is no exoneration of Pilate. The Jewish sin may be greater, but Pilate is nevertheless involved in a sinful action. Although he condemns Jesus with the $\dot{\varepsilon} \xi$ ov oi $\alpha$ given to him from above, he is still part of the hostile 'world'.

Scene VII (19:12-16a)

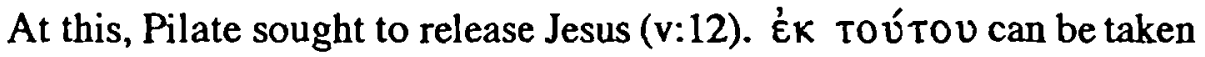
temporally or causally but in either case it appears to mean that as a result of his brief interview with Jesus Pilate now wants to release him. This appears to be the first time throughout the Johannine trial narrative that the governor has wanted to release the prisoner. Precisely what has brought about this change of attitude in Pilate is not stated. It is possible that, like the soldiers in Gethsemane, John wants to show that the pagan governor could not remain entirely unaffected by the prisoner before him, especially when the religious charge was to the fore. The imperfect use of $\varepsilon_{\zeta} \eta \dot{\tau} \tau 1 \dot{\alpha} \pi 0 \lambda \hat{v} \sigma \alpha \iota$ suggests a series of attempts, though John says nothing further.

\footnotetext{
${ }^{1}$ Barrett, Gospel, p 543.

2 6:64,71; 12:4; 13:2,11,21; 18:2,5; 21:20. Barreth, Gospel, p 543.

3 Brown similarly sees it as a reference to Caiaphas, or more generally to 'the Jews' (Gospel, pp 5681); Lindars sees it as a reference to the Jewish people as a whole. Dodd (Fourth, p 427) is probably correct to suggest that v:10 and 11 here reflect early Christian discussion concerning the responsibility for Jesus' death. If so, guilt is primarily attached to 'the Jews'

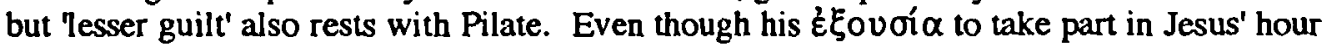
has come from God, he is not exonerated.
} 
'The Jews' within the Johannine narrative seem to realize that their introduction of the religious charge has produced entirely the wrong reaction in the governor, and so they revert to the political charge: If you release this man, you are not Caesar's friend; every one who makes himself a king sets himself

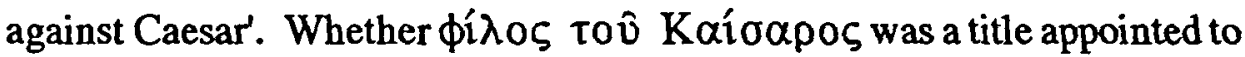
Pilate or not ${ }^{1}$, the meaning is clear: if Pilate released a messianic pretender he would not be protecting the interests of the emperor. This argument seems to have had the desired effect on Pilate; the use of $\alpha$ kov $\omega+$ gen shows the governor hearing with acceptance.

Pilate brings Jesus outside and sits down on the judgement seat, or $\beta \hat{n} \mu \alpha^{2}$. It may have been necessary to sit here only when passing sentence

\footnotetext{
${ }^{1}$ In Hellenistic times the 'Friends of the King' were a special group honoured by the king for loyalty (1Macc 2:18, 3:38, 10:65, 3Macc 6:23, Josephus Antiq 12\$298). The Friends of Augustus' were a well-known society in the early empire. Coins of Herod Agrippa I frequently read 'Philokaisar', a designation which Philo also gives him (In Flaccum 6.40). Bammel, 'Philos', pp 205-210 suggests that the title amicus Caesaris was old enough to be used at least in a semi-technical sense in this conversation. Sherwin-White, Roman, p 47, suggests that the term 'friend' is often used for of ficial representatives of the emperor at this time.

Barrett (Gospel, p 543) and Morris (Gospel, p 798), however, may be correct in stressing that John is not thinking in such a political, technical way and is simply using the

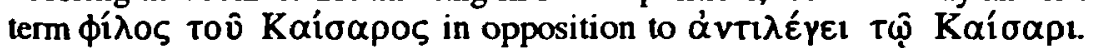

2 Josephus, War 2.301, describes Florus' $\beta \hat{n} \mu \alpha$ which stood in the forecourt of the governor's residence with steps leading up to it; the most eminent people of the city then presented themselves before the tribunal.
}

Several scholars have suggested that the verb éká $\theta \imath \sigma \varepsilon v$ here is used transitively (Eg Von Harnack, Loisy, Macgregor, Bonsirven, de la Potterie, Giblin), in which case it would mean that Pilate sat Jesus upon the judgement seat. As Barrett notes, it would lend further dramatic parallelism to the sequence of events in 19:2,3 and 5 where Jesus is dressed and crowned as a king ( $v: 2$ ), hailed by the soldiers (v:3) and brought out to his subjects, 'the Jews' (v:5); now in v: 13 he would be enthroned. Pilate's words in v:14, 'Behold your King', would also achieve a greater dramatic intensity if Jesus was actually enthroned. On a more theological level, it would fit in with the Johannine concept of Jesus as the real judge (5:30; $8: 16 ; 12: 31,47 ; 16: 11$. Brown, Gospel, p 880). Some traditional support for this interpretation can also be found in the Gospel of Peter 7 and Justin's Apology 50.35.6 where the Jewish people sit Jesus on the judgement seat and mock him. Persuasive as these arguments may appear, the weightier arguments seem to point in favour of an intransitive reading (See Blinzler, 'Entscheid', pp 175-182). The only other use of $x \alpha \theta_{i}^{\prime} \zeta \omega$ in John is intransitive (12:14, so too is 8:2) as it is commonly in the rest of the NT (Barrett, Gospel, p 544). If the verb was used transitively, we should expect it to be followed by a pronominal

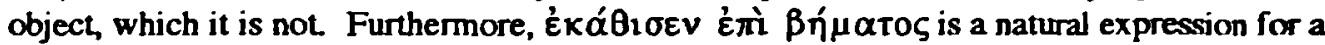
judge sittung upon the judgement seat; Josephus uses it of Pilate in War 2.172. Finally, the Johannine narrative would lose all credibility if the Roman governor is seen to have placed a prisoner on the judgement seat.

Perhaps John deliberately intends a double meaning here. Brown alleges that previous instances of Johannine double meaning have not been based on syntactical obscurities (Gospel, p 881), but we have already noted two instances in which John's use of active verbs suggests that Pilate has carried out something which, in all probability, was done by his soldiers $(19.1,22)$. This deliberate ambiguity will be met again at the end of the trial narrative (19:16-18) where the subjects of the verbs $\pi \alpha \rho \varepsilon \lambda \alpha \beta \sigma v$ and $\varepsilon \sigma \tau \alpha u ́ p \omega \sigma \alpha v$ are not stated and should logically and gramatically still be the $\alpha \rho x ı \rho \varepsilon i \varsigma$ of $v: 15$; the ambiguity shows that although the Roman soldiers actually carry out the crucifixion (19:23), the moral responsibility lies with 'the Jews'. In the present scene too John may want to be deliberately ambivalent: on the level of the narrative, Pilate sat on the judgement seat, but for those who 
and not throughout the whole trial ${ }^{1}$. Pilate is therefore about to pass sentence. However, the suspense of the narrative is suddenly broken by a description of where the $\beta \hat{\eta} \mu \alpha$ was located and the exact time. John states that it was the time to begin the slaughter of the passover lambs ${ }^{2}$.

Pilate says to 'the Jews' "I $\delta \varepsilon \dot{\delta} \beta \alpha \sigma \lambda \lambda \varepsilon \dot{\zeta} \varsigma \dot{v} \mu \omega \hat{v}$. Brown sees this as 'a final gesture of defiance and perhaps still with a half-hearted hope he can obtain clemency'3. But it is difficult to see how Pilate's words could hope to achieve Jesus' release. The prefect knows beyond any doubt that 'the Jews' have utterly rejected Jesus, and to describe the scourged prisoner, still dressed in mock-kingly regalia, as your king could only humiliate 'the Jews' further. After a brief attempt to release Jesus at the mention of the religious charge, Pilate seems to have reverted to his former position: that of mockery. Barrett, too, understands these words in such a way, writing: 'the helpless prisoner of Rome is the only king they are likely to have'4 .

The reaction of 'the Jews' is the same as in v:6 when Pilate said 'Behold

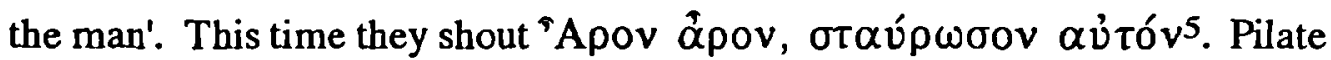
pushes them further, as in Mark: 'Shall I crucify your King?'. Again the prefect stresses that the prisoner is your king. This time the chief priests alone answer (the $\dot{u} \pi \eta \rho \varepsilon \varepsilon^{\prime} \alpha \mathrm{l}$ of v:6 are not mentioned): 'We have no king but Caesar'. In the OT, God alone is the only true king of Israel (Judg 8.23, 1 Sam 8.7); this kingship would be made visible in the rule of the Davidic king (2Sam 1.11,16). By claiming that the emperor was their only king, 'the Jews' broke the covenant whereby only God or his messiah was their sovereign. In John, this covenant was renounced just when preparations for the feast celebrating God's deliverance of his people were about to begin and forms a stark contrast to the words of the passover haggadah which praised the kingly reign of God6.

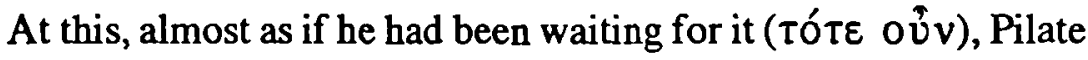
handed Jesus over 'to them' for crucifixion.

can see behind the human scene, the son of man is seated on his throne (Barrett, Gospel, $\mathrm{P}$ 544). .

${ }^{1}$ Mt 27:19 seems to envisage the governor seated on the $\beta \hat{\eta} \mu \alpha$ throughout the whole trial, as do the accounts of Paul before Festus in Acts 25:6, 17.

2 Ex 12:6 states that the lamb was to be kept alive until 14 Nisan, then slaughtered in the evening. This took place between the ninth and the eleventh hour (ie approximately 4-6 pm), see Josephus, War 6.423. For a description of the celebration of the feast see Sanders, Judaism, pp $135 f$.

3 Brown, Gospel, p 894.

4 Barrett, Gospel, p 545-546.

5 The cry in Lk 23:18 is similar, also Acts 21:36.

${ }^{6}$ See Meeks, Prophet, p 77; Sanders, Judaism, p 135. 
Again Pilate and 'the Jews' clash over the question of Jesus' kingship. Pilate has a sign written in Aramaic, Latin and Greek affixed to the cross

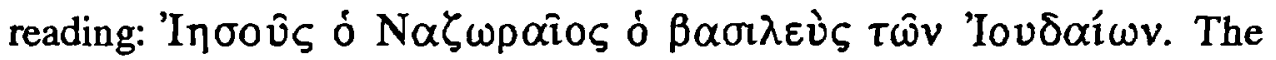
mockery here is obvious. Crucifixion was the most humiliating of Roman punishments, generally reserved for slaves or political agitators, usually from the lower classes ${ }^{1}$; furthermore, 'a hanged man is accursed by God' according to Dt 21:23. The figure of Jesus and the title clearly ridiculed Jewish messianic hopes. Not surprisingly, 'the Jews' take offence and ask Pilate to alter it. Pilate, however, stands firm in his mockery and replies " 0 үर́ $\gamma \rho \alpha \phi \alpha$,

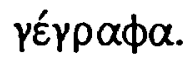

\section{Conclusion}

The Johannine Pilate is far from a weak and vacillating governor. He takes the case seriously and examines Jesus but quickly realizes that he is no political threat to Rome. But he seizes on the opportunity not only to mock the prisoner but also to ridicule 'the Jews' and their messianic hopes. Only once does he try to release Jesus and that is after the religious charge has been brought against him, a charge which the superstitious pagan finds alarming. Brought back to reality by the political threats of 'the Jews', Pilate resumes his mockery. But this time he is on the judgement seat and he is guiding 'the Jews' in a certain direction. Although he finds Jesus' messianic claims ridiculous, he is claiming some kind of kingship and could be dangerous in the crowded city at passover time. By the final scene, Jesus is to be put to death. But Pilate will exact a high price from 'the Jews'; if they want Jesus executed, they must not only renounce their messianic hopes but also the sovereignty of God, and unconditionally accept the sovereignty of Caesar. Only after this does Pilate hand Jesus over for crucifixion.

Pilate's failure to respond to Jesus means that he has allied himself with the hostile 'world' represented in Johannine thought by 'the Jews'2. In the Fourth Gospel, both 'the Jews' and Pilate are hostile towards Jesus ${ }^{3}$. Neither hear the word of Jesus and so are not of his 'sheep'. Although on one level the

\footnotetext{
1 Josephus describes it in War 7.203. See Hengel, Crucifixion, pp 1-10.

2 Meeks, Prophet, p 67.

3 Cf a similar tradition in Acts 4:25-27 (which also includes Herod) and Mark's presentation.
} 
Roman trial represents the judgement of Jesus, on a deeper more significant level it is Pilate and 'the Jews' who are judged. The trial represents the first part of Jesus' saying in 12:31: 'now is the judgement of this world, now shall the ruler of this world be cast out'. 'The ruler of this world' in Johannine thought is Satan, but he has his representatives in earthly rulers: 'the Jews' as religious, social leaders and Pilate representing the authority of Rome. In the proceedings before Pilate, all earthly authority is judged and found wanting by its response to Jesus.

The contrast between the true, dignified, other-worldly kingship of Jesus and that of Caesar implies that each member of John's community, constantly coming up against the might of imperial Rome, 'will always have to decide vis- $d$-vis the empire whether Jesus is his king or whether Caesar is' 1 .

\footnotetext{
1 Moeks, Propher, p 64 Cansdy, John s, pp 84 ff sumlarly suggeds that John's goopel was

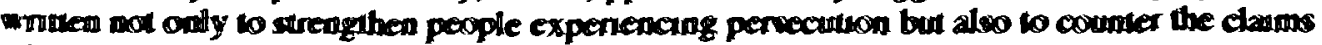
of the smpenall cullt.
} 


\section{CHAPTER 8}

\section{Historical Events behind the Gospel Narratives}

\section{a) The Historical Trial of Jesus}

Having looked at all four gospel accounts of the Roman trial, it should now be possible to distinguish to some extent between each evangelist's presentation of the scene and the actual historical facts. The complex set of historical questions which surround Jesus' trial have given rise to a vast amount of literature and cannot be investigated here ${ }^{1}$; the following discussion will look only at Pilate's involvement in the affair.

As we have seen, the evangelists' own particular theological and apologetic concerns have shaped their portrayals of Pilate to a large extent; this accounts for, amongst other things, Pilate's three-fold declaration of Jesus' innocence in Luke and John; his harsh mockery in Mark and John; and his offer of the choice between Jesus and Barabbas in Matthew. Yet despite this, all four gospels are in remarkable agreement regarding the basic facts: Jesus was arrested ${ }^{2}$, kept in Jewish custody for a night and brought to the Roman governor by the Jewish leaders ${ }^{3}$. This last fact is also confirmed by Josephus in the Testimonium Flavianum 4 . That Caiaphas and the chief priests were involved seems certain; quite possibly they were also joined by the lay leaders known variously as elders, rulers and scribes in the gospel accounts ${ }^{5}$. Early

\footnotetext{
'See the works cited in the bibliography.

${ }^{2}$ Only in John's gospel are Roman troops involved in the arrest (18:3). The historicity of this detail has been fiercely debated: on one side scholars argue that John is historically correct, suggesting that it is more likely that the Synoptics omitted the reference to soldiers here for apologetic reasons, eg Winter, Trial, pp 4450; Smallwood, Jews, p 168. But if Jesus really was arrested by Pilate's troops it scems strange that he was allowed to remain in Jewish custody and not taken straight away to the prefect, eg Barrett, Gospel, p 518; Bultmann, Gospel, p 637. McLaren suggests that the Captain of the Temple, mentioned in Luke, headed the arresting party, Power, p 94.

${ }^{3}$ The historicity of the trial before the Sanhedrin has been hotly disputed. For different scholarly views compare Lietzmann, Proze $\beta$, and Winter, Trial, with Blinzler, Proze $\beta$, and Sherwin-White, Roman, pp 24-47. See Catchpole, 'Problem', pp 47-65; Sanders, Judaism, pp 486ff; also McLaren, Power, pp 96-97 and notes for bibliography.

${ }^{4}$ Antiq 18.64.

${ }^{5}$ See Goodman, Ruling, p 115; McLaren, Power, p 91.
} 
the next morning a trial by cognitio extra ordinem followed 6 . The dominant charge seems to have that of claiming to be the 'King of the Jews', that is, some kind of political aspirant or insurrectionary. All four gospels record this charge during the trial and also its presence on the titulus at the crucifixion; such a charge would surely have been too embarrassing to the early Christians for them to have fabricated it ${ }^{7}$. Possibly other religious accusations were also brought against Jesus as a trial by cognitio allowed for multiple charges 8 . Pilate obviously accepted the Jewish charges, condemned Jesus and sent him to be scourged as a preliminary to crucifixion?.

Astronomical and calendrical calculations suggest that this incident took place at the passover of either AD 30 or $33^{10}$. Although other dates have occasionally been suggested ${ }^{11}$, the majority of scholars favour one of these.

${ }^{6}$ This is the timing given by both Mark and Matthew and accords well with what we know of the daily routine of a Roman official; see Pliny, Ep, 3.5.9-11; 6.16.4-5; Sherwin-White, Roman, p 45.

For the workings of this type of trial see chapter 1.

${ }^{7}$ On this charge see Harvey, Jesus, pp 2-5 and Constraints, pp 12-13. Bammel suggests that the wording on the titulus is 'in all likelihood authentic', 'Titulus', p 363.

${ }^{8}$ Sherwin-White, Roman, p 26 makes this point.

9That Jesus was executed by Pilate is also attested by Tacitus, Ann, 15:44, though it is possible that Tacitus' information was derived from Christian sources. Bammel, however, argues that Jesus was crucified by the Jews rather than the Romans, see 'Trial', pp 437ff. On the historical valuelessness of bSanh 43a see Blinzler, Trial, pp $23 \mathrm{ff}$.

It is probably not possible to say anything more with any certainty. The story of Pilate's wife's dream and Pilate's handwashing in Matthew are legendary/theological additions, as is the sending of Jesus to Herod in Luke. Furthermore, both Matthew and Luke, and quite possibly John, are all largely dependent upon Mark for their story of Jesus' trial before Pilate; though they may contain some historical traditions, their accounts are mainly reflections on the Markan account. One feature which does occur in all four narratives, however, is the release of Barabbas. Historically, Barabbas is one of the most obscure characters in the entire gospel tradition. Each of the gospels describe him in a different way (Mk 15:7, Mt 27:16, Lk 23:19, Jn 18:40). Rigg, 'Barabbas', pp 417-456, and Maccoby, 'Jesus', think that Jesus Barabbas was another name for Jesus of Nazareth. Loisy saw a link with the imbecile Karabas who was mocked as a king during Agrippa I's visit to Alexandria at passover time (Philo, In Flaccum §§36-39). See also Davies, 'Bar Abbas', pp 260-262. The majority of commentators see him as a political criminal. See Winter, Trial, pp 131-143. The possibility that Pilate may have occasionally offered to release a prisoner at Passover as an attempt to establish goodwill has already been raised in chapter 1. Yet even in the Markan account this detail has been so worked over that it is difficult to see what, if any, historicity lies behind it (Though see Bajsic, Jesus, who takes the account as historical and argues for a politically scheming Pilate). Possibly Pilate offered to release Jesus as a passover concession; or possibly Barabbas was released at about the same time, either because of an amnesty or because the accusations against him did not stand up in court. The precise historical relation between Barabbas and Jesus (if any) is impossible to reconstruct. For a fuller bibliography divided into scholars who see the Barabbas scene as historical and those who do not, see McLaren, Power, p 93, n 2. It is similarly difficult to determine what role (if any) a crowd may have had in the proceedings.

10 See Fotheringham, 'Evidence', pp 146-162; also Finegan, Handbook, p 161.

${ }^{11}$ For example Eisler, Messiah, p 17, claimed that the Maximinian Acta Pilati referred to by Eusebius ( $H E$ 1.9) were not forgeries and proved that the date of the crucifixion was AD 21 (the dates in Antiq 18.135 and 139 being Christian forgeries based on Lk 3:1). For fuller discussion and evidence that Pilate only came to office in AD 26 see chapter 1. 
To a great extent the discussion has revolved around the alleged link between Pilate, Sejanus and an anti-Jewish plot. Several scholars, taking the accounts of Pilate in Josephus, Philo and the gospels fairly uncritically, have emphasized the harshness of Pilate in Jewish sources and the supposed weakness of Pilate in Christian ones. They explain this by suggesting that all the events recorded by the Jewish writers (except the incident with the Samaritans which led to Pilate's deposition) happened whilst Pilate had the backing of his powerful ally, the anti-Jewish prefect of the Praetorian Guard, Sejanus. The trial of Jesus, however, must have occurred after Sejanus' assassination in October $\mathrm{AD} 31$, ie passover 33; thus the governor's weakness and final capitulation was a result of the changed political climate in which his own position was suddenly much more precarious ${ }^{12}$. This theory, however, has two main weaknesses. First, there is no evidence for the existence of an anti-Jewish plot between Sejanus and Pilate ${ }^{13}$. Secondly, as the whole of this study has tried to show, there is no fundamental discrepancy between the Pilate of the gospels and that of Josephus and Philo ${ }^{14}$. Both 30 and 33 therefore remain equal possibilities ${ }^{15}$.

The above reconstruction, though only in its barest outline, gives the impression of a competent governor working alongside the Jewish hierarchy in executing a suspected political agitator. Schwartz notes the parallels between Pilate's handling of Jesus and Antipas' move against John the Baptist recorded by Josephus: 'it would be much better to strike first and be rid of him before his (John's) work led to an uprising, than to wait for an upheaval, get involved in a difficult situation and see his mistake' ${ }^{16}$. Doubtlessly Pilate supposed that by executing the leader the movement would quickly fade away.

\footnotetext{
${ }^{12} \mathrm{See}$ the introduction for a fuller account of this view. Those holding this position include Stauffer, Jerusalem, pp 16-18; Bammel, 'Philos', cols 205-210; Doyle, 'Pilate's Career; Meier, 'Episode', pp 4-13; Wansbrough, 'Suffered', pp 92-93.

${ }^{13}$ See in particular Hennig, Aelius, pp 160-179; Schwartz, 'Josephus and Philo', pp 35-36.

${ }^{14}$ McGing, 'Pontius', makes the same point, pp 428-438.

15 Tumer, 'Chronological', though rejecting the Sejanus link, favours AD 33; so too does Smallwood, Jews, p 168, $\mathrm{n}$ 82. Those in favour of 30 include Kraeling, 'Episode', pp 288-289 and Finegan, 'Handbook', p 161. For fuller discussions of the historical data see Turner, 'Chronological', pp 67-74, and Meier, 'Episode', pp 4-13.

16 Antiq 18.118; Schwartz, 'Pontius', p 400.
} 


\section{b) Historical Events behind Lk 13:1}

Nothing further is known of this incident, either from biblical or nonbiblical sources, and the reference to it here in Luke is extremely brief. We are told only that Pilate has mingled the blood of some Galileans with their sacrifices.

Due to the silence of other first century writers regarding this incident, particularly Josephus, several scholars have suggested that Luke has misreported another event from first century Palestine at this point. All known events from Pilate's term of office have been suggested. Kraeling thought that Luke was actually referring to the time when Pilate brought military standards into Jerusalem (War 2.169-174; Antiq 18.55-59) ${ }^{17}$; the most obvious problem with this, however, is that according to Josephus that incident led to a peaceful protest at Caesarea which ended without bloodshed. Olmstead linked Lk 13:1 with the aqueduct protest (War 2.175-177; Antiq 18.60-62) 18; however, there is no indication in Josephus that those caught up in the protest were Galileans, the natural assumption is that they were Judaean subjects of Pilate. Wellhausen suggested that the incident should be linked to Pilate's putting down of a Samaritan uprising (Antiq 18.86-87) ${ }^{19}$; again, those involved are Samaritans and not Galileans and the incident takes place near Mt Gerizim, not in Jerusalem. Other suggestions are Archelaus' slaughter of 3,000 at about passover time (War 2.8-13; Antiq 17.213-218) ${ }^{20}$ and, with even less probability, the execution of 6,000 Jews by Alexander Jannaeus (Antiq $13.372)^{21}$. With the possible exception of the aqueduct episode 22 , none of these incidents seems remotely close to what Luke describes.

Going back to the gospel, the context of 13:1-5 seems to imply that the number of Galileans killed was not particularly high. Marshall suggests that it may have been no more than a couple whilst Fitzmyer suggests less than eighteen ${ }^{23}$. The season seems to have been passover since this was the only

17Kraeling, 'Episode', pp 286-288. For fuller discussions of these incidents, see chapter on Pilate in Josephus.

18Olmstead, Jesus, pp 147-149; also raised as a possibility by Smallwood, Jews, p 163 and Schwartz, 'Pilate', p 398.

19 Wellhausen, Evangelium, p 71.

20Johnson, Note', pp 91-95; Derrett, 'Galileans', p 103.

${ }^{21}$ T. Zahn, cited by Fitzmyer, Gospel, p 1007.

22 It is not impossible that Luke has this episode in mind but has altered Judaeans to Galileans as a deliberate attempt to show Pilate's harsh treatment of Galileans in order to add suspense to the prefect's meeting with Jesus.

${ }^{23}$ Marshall, Gospel, p 553; Fitzmyer, Gospel, p 1006. 
time when the Israelites slaughtered their own sacrifices ${ }^{24}$. As these sacrifices were always slain in the Temple ${ }^{25}$, Luke's description raises the question of whether he envisages the killing of the Galileans to have taken place in the Temple itself at the point of sacrificing. That is, did Pilate's men not only kill the Galileans but also desecrate the Temple 26 ? Unfortunately, the account in Lk 13:1 is too brief to be able to reconstruct the events with any certainty, but Winter is probably correct in his assertion that the reference to mingling Galilean blood with their sacrifices is 'oriental picture language' and does not necessarily imply that Pilate's men actually entered the Temple ${ }^{27}$. Perhaps the most that can be said about this incident is that for some unknown reason Pilate had a small group of Galileans executed whilst they visited Jerusalem for the passover.

Cullmann suggested that the Galileans were Zealots and that their 'sacrifices' were actually men: 'probably we have to do here with a Zealot uprising in which some Romans, or at least officials of the State lost their lives'28. However, there is no evidence for any kind or 'Zealot movement' in the 20 s and $30 \mathrm{~s}^{29}$. Quite possibly the Galilean pilgrims were caught up in some kind of anti-Roman demonstration but we have no way of reconstructing what form that may have taken.

Exactly when it took place is equally unknown. Blinzler suggested that the Galileans were those who wanted to make Jesus king in Jn 6:15 and that the incident occurred at the passover of AD 29, a passover when Jesus was not present in Jerusalem ${ }^{30}$. This, however, is extremely hypothetical and the incident could have taken place any time during Pilate's term of office ${ }^{31}$.

If the event involved only a few Galileans and there was no suggestion of any defilement of the Temple, then it is not particularly surprising that Josephus does not mention it. All the occurrences which he does describe were fairly large scale demonstrations. Perhaps too as a Judaean he would not have been particularly interested in Galileans. It is not only possible but quite likely that Pilate's govemorship contained many such brief outbreaks of

\footnotetext{
24M.Pes v.6, Lev 1:5; see Jeremias, Jerusalem, p 79.

25Jeremias, Jerusalem, p 78.

26.So implicitly Fitzmyer, Gospel, p 1006 and Smallwood, Jews, p 163.

27Winter, Trial, p 177, n 9; also Cullmann, Stale, p 14, and Marshall, Gospel, p 553.

${ }^{28}$ Cullmann, State, p 14; followed by Vermes, Jesus, p 47.

${ }^{29}$ Hengel, Zealots, doubts that this was a Zealot uprising, $\mathrm{p} 338$.

30 Blinzler, 'Niedermetzlung', pp 43ff.

${ }^{31}$ So also Winter, Trial, p 176, n 9.
} 
trouble about which we know nothing; the insurrection in which Barabbas was caught up, if historical, may well be another example (Mk15:7, Lk 23:19). 


\section{CONCLUSION}

Pontius Pilate is one of the few New Testament characters about whom we have two lengthy descriptions coming from roughly contemporary non-biblical sources. The material concerning him, therefore, affords us with an interesting opportunity to assess the way in which all these sources, both biblical and non-biblical, treat historical characters. How far did each writer feel bound by historical events? How far has each allowed his own particular bias to influence his portrayal of Pilate?

This study has examined all six sources in turn - Philo, Josephus and the four gospels. In each case it has become apparent that the author's portrayal of Pilate has been influenced to a great extent by his own particular theological, apologetic and/or community situation. Yet despite the strongly interpretative nature of the sources, it has been possible to piece together something of the historical Pilate.

As the prefect of Judaea from AD 26 to 37, Pilate was charged with maintaining law and order in the imperial province, hearing capital cases and supervising the collection of taxes. Although small, the province presented many difficulties, particularly in that it was composed of four different ethnic groups, each with their own religious sensitivities. It was therefore particularly important that the prefect maintained good relations with the Jewish High Priest Caiaphas and the rest of the aristocracy. The issue of coinage also fell within the duties of the governor; archaeological evidence shows that Pilate, unlike other governors of Judaea, minted coins containing both Jewish and Roman designs. Although the pagan designs may not have been particularly offensive, the coins do seem to reflect a tendency to want to bring Judaea into line with other Roman provinces.

The episode of the standards narrated by Josephus shows a governor intent on inaugurating his government with a firm hand; he appears to be reluctant to take any nonsense from the people he is to govern. Yet at the same time he can show flexibility and an ability to stand down in the interests of preserving the peace. The construction of the aqueduct shows an ability to work alongside the priestly authorities. It was perhaps conceived of as a joint venture, Jewish and Roman authorities working together for the benefit of the people of Jerusalem. Yet even when matters got out of hand, he does not appear to have resorted to undue aggression. The early years of Pilate's governorship were made particularly difficult by the absence of the Syrian 
legate; the protection normally afforded by the legate's four legions was missing and so it would have been particularly important to quell uprisings before they got out of hand.

The execution of Jesus was in all probability a routine crucifixion of a messianic agitator. Pilate, however, executed only the ringleader and not his followers. This may again show a dislike of excessive violence, but also shows prudence at the potentially volatile Passover season. Again, the governor appears to have worked closely with the Jewish hierarchy.

An event recorded only by Philo shows Pilate's attempt to show loyalty to his emperor. Yet it is significant that he seems to have gone out of his way to make sure that the shields did not contain images and had them hung in his own residence - surely the most appropriate place in Jerusalem for them.

Finally, in a passage again referred to only by Josephus, we hear of Pilate putting down a Samaritan uprising. A good governor could not allow such a potentially dangerous movement to escalate; he was therefore acting well within his duties as the protector of Roman law and order. His actions were again not unnecessarily severe, only the leaders and influential people were put to death. It was because of Samaritan complaints about Pilate's handling of this affair that he was sent back to Rome. There is, however, no certain indication that Vitellius thought Pilate was to blame in his handling of the affair; the legate simply decided to refer the whole matter to Tiberius. The outcome of Pilate's trial is unknown but, even if the verdict had been in Pilate's favour, the fact that he had governed for ten years and the accession of a new emperor meant that it was the obvious time to accept a new commission.

With this sketch of the historical prefect in mind, we are in a better position to see how each of the six writers has interpreted Pilate as a literary character within their writings and to begin to suggest reasons for each particular portrayal. Philo, for example describes Pilate's character as utterly contemptible, his government oppressive. Yet this characterization conforms to that of others in Philo's Legatio and In Flaccum who disrespect the Jewish nation and its law and stems ultimately not so much from the historical Pilate but from both Philo's political apologetic (the aim of which is to persuade Claudius not to adopt Gaius' attitude towards the Jews) and his theology (in which the enemies of the Jews are the enemies of God).

Josephus too does not rate Pilate highly. Yet, as this study has demonstrated, even within his two works, the Antiquities of the Jews and the Jewish War, Pilate is portrayed in a slightly different manner. In the earlier work, the Jewish War, Pilate is shown as insensitive towards the Jewish 
people and their law, yet he can be moved by a religious demonstration and dislikes excessive bloodshed. Josephus uses the two events in Pilate's governorship to strengthen the War's foremost apologetic aim: resistance against Rome is futile, only passive acceptance of Imperial rule can produce harmony amongst subject peoples. The Antiquities on the other hand is far more negative in its assessment of Pilate's character. This work shows a much greater interest in the personal histories of characters within the story, even incidental ones; also the relationship between guilt and fate, particularly in relation to the Jewish law, is explored. Pilate sets himself up against that law, and it is this attitude which ultimately determines his fate and leads to his removal from the province.

Above all, I have tried to show that the gospel accounts of Pilate are not uniform; they do not all present a 'weak' Pilate as is often supposed. In fact, the whole usual demarcation between the 'harsh, aggressive Pilate' of the Jewish sources and the 'weak Pilate' of Christian ones is much too simplistic. Instead, the gospels contain a great deal of diversity in their presentations of the prefect linked, as with the Jewish writers, to the needs of the community for which they were writing.

For Mark, Pilate is far from weak and vacillating. He is a skilful politician, manipulating the crowd to avoid a difficult situation, a strong representative of imperial interests. This particular picture of a strong, domineering Pilate ties in well with the element of persecution behind Mark's gospel. In Matthew's gospel, however, Pilate plays a less significant role within the Roman trial scene. The portrayal of the prefect, and therefore of Rome, is secondary to Matthew's interest in showing the Jewish nation rejecting its messiah and accepting responsibility for this action, suggesting that for Matthew's community relations with the Jewish synagogue were more serious and urgent than relations with Rome. Yet Pilate is still not described favourably; he symbolizes other Roman governors before whom members of Matthew's community may be forced to stand trial.

In Luke's presentation, Pilate plays an important role as the representative of Roman law in declaring Jesus innocent. Yet, like other govemors before whom Christians are made to stand trial in Acts, he is of a rather dubious character. His principal characteristic is weakness as he allows representatives of the Jewish nation to force him to condemn an innocent man. In contrast, John's Pilate is manipulative, derisive and sure of his own authority. He will go along with Jewish wishes in condemning Jesus but exacts a high price from them in their acceptance of Caesar as their only king. In John's presentation, Pilate is allied with the hostile 'world' which rejects 
Jesus; as Jesus prepares for his glorification on the cross all earthly rulers, Pilate representing Rome and 'the Jews', are judged and found wanting by their negative response to him.

Since at least three of the gospels are bound by literary dependence, the obvious inference to be drawn from their accounts of Pilate is that each evangelist altered and interpreted the historical Pilate, or the Pilate of his source, in a way which had relevance for his own community. The differences highlighted by this study suggest that social context played as great a part in the presentation of early Christian events as tradition. Certain key points had to be adhered to, but the community situation was the fundamental factor in determining the way in which each evangelist portrayed the prefect. If this is the case with the Pilate material, it is reasonable to suppose that social context was as important as tradition in the rest of the gospel narratives.

A further point which has come out of this study is that there is no evidence of a linear progression throughout the gospels in which Pilate becomes progressively friendlier towards Christianity (as was supposed by Winter and others). The situation was much more complex; the gospel writers' presentations of Pilate (and so of Rome) were determined not so much by date as by their own social, geographical and political situations.

In the normal course of things, Pilate, like his fellow Roman governors, would have been all but forgotten; an obscure name in the pages of Philo and Josephus. Yet a chance encounter with Jesus of Nazareth ensured that his name survived in Christian recollection. It was one historical event the trial of Jesus - which necessitated Christian reflection and therefore gave rise to the differing Christian 'Pilates of Interpretation'. Yet interpretations of Pilate and his role as the judge of Jesus of Nazareth did not end with the first century, or even apocryphal or mediaeval literature. As the introduction to this work has shown, even twentieth century works on Pilate are interpretations, designed to speak to their own times and situations. This is the case not only when the works come out of Stalinist Russia or Nazi Germany, but out of any social, political or economic situation. Even popular imagination, focusing on the Roman in search of truth, the judge washing his hands or the indecisive governor, contributes to the many 'Pilates of Interpretation' of our own time. 
Applebaum, S. 'Judaea as a Roman Province; the Countryside as a Political and Economic Factor', ANRW II.8 (1977), pp 355-96.

Attridge, H.W. 'Josephus and his Works', in CRINT (ed. S. Safrai and M. Stern), pp 185-232.

Balsdon, J.P.V.D. 'The Principates of Tiberius and Gaius', ANRW II.2 (1975), pp 86-94.

Bammel, E. 'Syrian Coinage and Pilate', JJS 2 (1950/1), pp 108-10.

___ 'Philos tou Kaisaros', ThLZ 77 (1952), cols 205-10.

__ 'Pilatus, Pontius', RGG 5 (3rd ed, 1961), cols 383-4. with C.F.D. Moule (eds), Jesus and the Politics of his Day, CUP, Cambridge (1984).

Baras, Z. 'The Testimonium Flavianum and the Martyrdom of James' in Josephus, Judasim and Christianity, (ed. L.H. Feldman and G. Hata), pp 338-48.

Barnett, P.W. 'Under Tiberius all was Quiet', NTS 21 (1974-5), pp 56471.

Bartlett, J.R. Jews in the Hellenistic World, CUP, Cambridge (1985).

Betz, O. 'Miracles in the Writings of Flavius Josephus' in Josephus, Judaism and Christianity, (ed. L.H. Feldman and G. Hata), pp 212-235.

Bilde, Per Flavius Josephus between Jerusalem and Rome: his Life, his Works and their Importance, Journal for the Study of the Pseudepigrapha Supplement Series 2, Sheffield Academic Press (1988).

Blinzler, J. 'Pilatus, Pontius', LTK 8 (1963), cols 504-5.

Boddington, A. 'Sejanus, Whose Conspiracy?', American Journal of Philology 84 (1963), pp 1-16.

Borgen, P. 'Philo', in CRINT (ed. S. Safrai and M. Stern), vol II.2, pp 233-82. 
Philo, John and Paul: New Perspectives on Judaism and Early

Christianity, Brown Judaic Studies 131, Scholars Press, Atlanta (1987).

Bowman, J. 'Pilgrimage to Mt Gerizim', Eretz Israel 7 (1964), pp 17-28.

'Early Samaritan Eschatology', JJS 6 (1955), pp 63-72.

Brandon, S.G.F. The Fall of Jerusalem and the Christian Church, SPCK, London (2nd ed. 1957).

Jesus and the Zealots, Manchester University Press, Manchester (1967).

'Pontius Pilate in History and Legend', History Today 18(1968), pp 523-30.

Broydé, I. 'Pilate, Pontius', Jewish Encyclopaedia (1905), vol X, pp 345.

Brunt, P.A. 'Charges of Maladministration under the Early Principate', Historia X (1961), pp 189-227.

'Procuratorial Jurisdiction', Latomus 25 (1966), pp 461-89.

Buckley, F.J. 'Pilate, Pontius', New Catholic Encyclopaedia (1967), vol 11, pp 360-1.

Campbell, B. The Roman Army 3IBC-AD 337: A Sourcebook, Routledge, London (1994).

Cerulli, E. Tiberius and Pontius Pilate in Ethiopian Tradition and Poetry', Proceedings of the British Academy LIX (1973), pp 141-58.

Cheeseman, G.L. The Auxilia of the Roman Imperial Army, Clarendon Press, Oxford (1914).

Cohen, S.J.D. Josephus in Galilee and Rome, E.J. Brill, Leiden (1979).

Cohn, L. 'Einleitung und Chronologie der Schriften Philos', Philologus Suppl vii (1899), pp 389-463.

Colson, F.H. The Embassy to Gaius, Loeb Vol X, Heinemann, London, Harvard University Press, Massachusetts (1962)

In Flaccum, Loeb Vol IX, Heinemann, London, Harvard University

Press, Massachusetts (1960) 
Davies, P.S. The Meaning of Philo's Text about the Gilded Shields' JTS 37 (1986), pp 109-114.

Deissman, A. Light from the Ancient East, (Trans L.R.M. Strachan), Hodder \& Stoughton, London (1927).

de Laet, S.J. 'Le successeur de Ponce Pilate', L'Antiquite Classique 8(1939), pp 413-9.

Dessau, H. Inscriptiones Latinae Selectae, Hildebrand, Berlin (1962), vols IIII.1.

Doyle, A.D. 'Pilate's Career and the Date of the Crucifixion' JTS 42 (1941), pp 190-193.

Eybers, I.H. The Roman Administration of Judaea between AD 6 and 41, with special reference to the procuratorship of Pontius Pilate', Theologica Evangelica (1969), pp 131-46.

Eisler, R. The Messiah Jesus and John the Baptist, Methuen, London (ET 1931).

Fascher, E. 'Pilatus, Pontius', PW 20 (1950), cols 1322-1323.

Feldman, L.H. Jewish Antiquities: Books xviii-xx, Loeb, Vol IX, Harvard University Press, Massachusetts (1969). with Hata, G. Josephus, Judaism and Christianity, E.J. Brill, Leiden (1987). 'Josephus' in $A B D$, Doubleday (1992), Vol III, pp 981-98.

Ferguson, J. 'Roman Administration', Civilization of the Ancient Mediterranean: Greece and Rome, (ed. M. Grant and R. Kitzinger), vol I, pp 649-65.

Fuks, G. 'Again on the episode of the gilded Roman shields at Jerusalem' HThR 75 (1982), pp 503-7.

Garnsey, P. The Criminal Jurisdiction of Governors', JRS (1968), pp 51-9.

Goodenough, E.R. The Politics of Philo Judaeus, Georg Olms, Hildesheim (1967). Jewish Symbols in the Graeco-Roman Period, vols I-XIII, Pantheon Books, New York (1953). 
Goodman, M. The Ruling Class of Judaea, CUP, Cambridge (1987).

Grant, M. Aspects of the Principate of Tiberius, Numismatic Notes and Monographs no. 116, New York (1950).

with R. Kitzinger, Civilization of the Ancient Mediterranean: Greece and Rome, vols I-III, Charles Scribner's Sons, New York (1988).

Gutman, J. The "Second Commandment" and the Image in Judaism', Hebrew Union College Annual 32 (1961), pp 161-74.

Haacker, K. 'Samaritan' in Dictionary of New Testament Theology, Vol 3, pp 449-467, (ed. Colin Brown), The Paternoster Press, Exeter (1978).

Hachlili, R. Jewish Ornamented Ossuaries of the late Second Temple Period, Reuben and Edith Hecht Museum, University of Haifa (1988).

Hedley, P.L. 'Pilate's Arrival in Judaea' JTS 35(1934), pp 56-7.

Hengel, M. Judaism and Hellenism, 2 vols, Fortress Press, Philadelphia (1974).

Crucifixion in the Ancient World and the Folly of the Cross, SCM, London (1977).

The Zealots: an Investigation into the Jewish Freedom Movement in the Period from Herod I until $70 A D, T$ \& T Clark, Edinburgh (ET. 1981).

Between Jesus and Paul, SCM, London (1983).

The 'Hellenization' of Judaea in the First Century after Christ, SCM

Press, London/Trinity Press International, Philadelphia, (1989). with R. Deines, The Pre-Christian Paul, SCM, London (1991).

Hennig, D. L. Aelius Seianus, C.H. Beck'sche, Munich (1975), pp 160-79.

Hilliard, A.E. and Clavier, H. 'Pilate', Dictionary of the Bible, (ed. Hastings), T \& T Clark, Edinburgh, (2nd ed. 1963), pp 771-2.

Hoehner, H. Herod Antipas, SNTS, Monograph Series, CUP (1972).

Holzmeister, U. 'Wann war Pilatus Prokurator von Judaea?', Bib 13 (1932), pp 228-32.

Horsley, R.A. 'Josephus and the Bandits', JSJ 10 (1979), pp 37-63. 
'Popular Messianic Movements around the Time of Jesus', $C B Q 46$ (1984), pp 471-95.

and Hanson, J.S. Bandits, Prophets and Messiahs: Popular

Movements at the Time of Jesus, Winston Press, Minneapolis (1985).

Isaac, B. The Limits of Empire: The Roman Army in the East, Clarendon

Press, Oxford (revised ed. 1992)

Jones, A.H.M. The Herods of Judaea, Clarendon Press, Oxford (1938).

Studies in Roman Government and Law, Blackwell, Oxford (1960).

'I appeal to Caesar', in Studies, pp 51-65.

'The Aerarium and the Fiscus', Studies, pp 99-114.

'Procurators and Prefects in the Early Principate', in Studies, pp 115-

25.

Juster, J. Les Juifs dans l'Empire romain. Leur condition juridique, économique et sociale, vols I-II, Paris (1914).

Kinman, B. 'Jesus' "Triumphal Entry" in the Light of Pilate's', NTS 40 (1994), pp 442-8.

Koester, H. Introduction to the New Testament, Vol I: History, Culture and Religion of the Hellenistic Age, Fortress Press, Philadelphia (2nd English edition, 1983).

Kraeling, C.H. 'The Episode of the Roman Standards at Jerusalem', HTR 35 (1942), pp 263-89.

Lémonon, J.P. Pilate et le gouvernement de la Judée: textes et monuments, Études bubliques, Gabalda, Paris (1981).

Levick, B. Tiberius the Politician, Thames \& Hudson, London (1976). The Government of the Roman Empire, Croom Helm, London (1985).

Liberty, S. 'The Importance of Pontius Pilate in Creed and Gospel', JTS 45 (1944), pp 38-56.

Lintott, A. Imperium Romanum: Politics and Administration, Routledge, London (1993). 
Lohse, E. 'Die römischen Statthalter in Jerusalem', ZDPV 74 (1958), pp 6978.

MacDonald, J. The Theology of the Samaritans, SCM Press, London (1964).

Maier, P.L. 'Sejanus, Pilate and the Date of the Crucifixion', Church History 37 (1968), pp 3-13.

Pontius Pilate, New York (1968).

'The Episode of the Golden Roman Shields at Jerusalem' HThR 62 (1969), pp 109-21.

Massebieau, M.L. 'Le classement des oeuvres de Philon', Bibliotèque de .l'Ecole des Hautes Études, Sciences Religieuses 1 (1899), pp 1-91.

Mayer, G. Index Philoneus, Walter de Gruyter, Berlin, New York (1974).

Maxfield, V.A. The Military Decorations of the Roman Army, Batsford, London (1981).

McGing, B. 'Pontius Pilate and the Sources' CBQ 53 (1991), pp 416-38.

McLaren, J. Power and Politics in Palestine, JSNT Supp Series 63, Sheffield Academic Press, Sheffield (1991).

Millar, F. 'Equites' (under the Empire), OCD, pp 403-4.

Mommsen, T. Römisches Strafrecht, Dunker \& Humbolt, Leipzig (1899).

Montgomery, J.A. The Samaritans: the Earliest Jewish Sect, their History, Theology and Literature KTAV Publishing House, New York (1968) [first published 1907].

Moore, C.A. Esther, The Anchor Bible, Doubleday \& Co. Inc, New York (1971).

Morison, F. And Pilate Said... Rich \& Cowan, London (1939).

Müller, G.A. Pontius Pilatus, der füfte Prokurator von Judäa ind Richter Jesu von Nazareth, Metzler, Stuttgart (1888).

Neusner, J. From Politics to Piety: the Emergence of Pharisaic Judaism, 2nd ed: Ktav, New York (1979).

Nock, A.D. The Roman Army and the Roman Religious Year', HThR 45 (1952), pp 187-252. 
Ollivier, M.J. 'Ponce Pilate et les Pontii', RB 5 (1896), pp 247-54, 594-600.

Pelletier, A. Legatio ad Gaium Introduction, Traduction et Notes, Les Euvres de Philon d'Alexandrie vol 32, R. Armaldez, C. Mondésert, J. Pouilloux, Centre National de la Recherche Scientifique and Association of friends of the University of Lyon, Paris (1972).

Peter, H. 'Pontius Pilatus, der Römische Landpfleger in Judäa', Neue Jahrbuch für des klassiche Altertum Geschichte und deutsche Literatur 19 (1907), pp 1-40.

Pflaum, H.G. Les Procurateurs équestres sous le Haut-Empire Romain, vols - I-III, Adrien Maisonneuve, Paris (1950). Les Carrières Procuratoriennes Équestres sous le Haut-Empire Romaine, Paul Geuthner, Paris (1960), Supplement (1982).

Purves, G.T. 'Pontius Pilate', Hastings Dictionary of the Bible (1900), vol III, pp 875-9.

Rajak, T. Josephus: the Historian and his Society, Duckworth, London (1983).

Reike, B. The New Testament Era, Adam \& Charles Black, London (ET 1969).

Rengstorf, K.H. A Complete Concordance to Flavius Josephus E.J. Brill, Leiden (1975).

Roth, C. 'An Ordinance against Images in Jerusalem AD 66', HThR 49 (1956), pp 169-77.

Roth, L. 'Pontius Pilate', Encyclopaedia Judaica (1971), vol 13, col 848.

Safrai, S. and Stern, M. (eds) The Jewish People in the First Century, Compendia Rerum Iudaicarum ad Novum Testamentum, Van Gorcum \& Co. B.V.-Assen (1974).

Saller, R.P. Personal Patronage under the Early Empire, CUP, Cambridge (1982).

'Roman Class Structures and Relations', in Civilization, (ed. M. Grant and R. Kitzinger), vol I, pp 549-73. 
Sanders, E.P. Judaism: Practice and Belief: 63 BCE - 66CE, SCM, London (1992).

Sandmel, S. 'Pilate, Pontius', IDB (1962), vol 3, pp 811-13.

Sandys, J.E. Latin Epigraphy, CUP, Cambridge (1927).

Schürer, E. The History of the Jewish People in the Age of Jesus Christ, revised and edited by G. Vermes, F. Millar, M. Goodman, vol I, T \& T Clark Ltd, Edinburgh (1973).

Schutt, R.J.H. Studies in Josephus, SPCK, London (1961).

Schwartz, D.R. 'Josephus and Philo on Pontius Pilate', The Jerusalem . Cathedra 3 (1983), pp 26-45.

Agrippa I: TheLast King of Judaea, J.C.B. Mohr (Paul Siebeck),Tübingen (1990).

'Pontius Pilate's Appointment to Office and the Chronology of Antiquities, Books 18-20', Studies in the Jewish Background of Christianity, J.C.B. Mohr (Paul Siebeck), Tübingen (1992), pp 182-201.

'Pontius Pilate', $A B D$ (1992), vol 5, pp 395-401.

Shanks, Hershel Judaism in Stone: the Archaeology of Ancient Synagogues, The BiblicalArchaeology Society, Washington/Harper \& Row Publishers Inc, New York/Steimatzky's Agency Ltd, Tel Aviv, (1979).

Shatzman, I. The Armies of the Hasmonaeans and Herod: From Hellenistic to Roman Frameworks, J.C.B. Mohr (Paul Siebeck), Tuibingen (1991).

Shaw, B.D. 'Roman Taxation', Civilization of the Ancient Mediterranean: Greece and Rome, (ed. M. Grant and R. Kitzinger), vol II, pp 80927.

Sherwin-White, A.N. 'Procurator Augusti', PBSR 15, New Series 2, (1939), pp 11-15.

Roman Society and Roman Law in the New Testament, Clarendon Press, Oxford (1963).

Shutt, R.J.H. Studies in Josephus, SPCK, London (1961). 
Smallwood, E.M. 'The Date of the Dismissal of Pontius Pilate from Judaea', JJS 5 (1954), pp 12-21.

'Some Notes on the Jews under Tiberius', Latomus 15 (1956), pp 31429.

'High Priests and Politics in Roman Palestine', JIS 13 (1962), pp 1434.

Philonis Alexandini Legatio ad Gaium, E.J. Brill, Leiden (1970).

The Jews under Roman Rule: from Pompey to Diocletian, E.J. Brill, Leiden (1976).

'Philo and Josephus as Historians of the Same Events' in Josephus, Judaism and Christianity, (ed. L.H. Feldman and G. Hata), pp 11429.

Souter, A. 'Pilate', Dictionary of Christ and the Gospels, ed. J. Hastings (1908), vol III, pp 363-366.

Stauffer, E. Christ and the Caesars, SCM, London (ET 1955).

__ 'Zur Münzprägung und Judenpolitik des Pontius Pilatus', La Nouvelle Clio 1-2 (1949-50), pp $511 \mathrm{ff}$. Jerusalem und Rom in Zeitalter Jesu Christi, Dalp-Taschenbuicher 331, Franke, Bern (1957).

Die Pilatusinschrift von Caesarea Maritima, Erlanger

Universitätsreden, N.F. 12, Erlangen (1966).

Stern, M. 'Josephus and the Roman Empire as Reflected in the Jewish War' in Josephus, Jusaism and Christianity, (ed. Hata, Feldman), pp 7180.

Spiedel, M.P. 'The Roman Army in Judaea under the Procurators', in Roman Army Studies, vol 2, Franz Steiner, Stuttgart (1992).

Stevenson, G.H. Cambridge Ancient History, vol 10: The Augustan Empire. 44 BC-AD 70, CUP, Cambridge (Reprinted 1966).

Talmon, S. 'Wisdom in the Book of Esther', VT 13 (1963), pp 419-55.

Thackeray, H. St.J. The Jewish War, Loeb Vols II and III, Heinemann, London (1927). 
Ed.The Antiquities of the Jews, Loeb Vol IV, Heinemann, London (1961).

Ed. The Life/Against Apion, Loeb Vol I, Heinemann, London (1961).

Theissen, G. The Shadow of the Galilean, SCM, London (1987).

Turner, H.E.W. 'The Chronological Framework of the Ministry', in Historicity and Chronology in the New Testament, D.E. Nineham et al, SPCK, London (1965), pp 59-74.

Vardaman, E.J. 'A New Inscription Which Mentions Pilate as Prefect', JBL 81(1962), pp 70-1.

von Dobschütz, E. 'Pilatus', Real-Enzyclopaedie für Protestantische Theologie und Kirche, (1904), vol 15, cols 397-401.

Wansbrough, H. 'Suffered under Pontius Pilate', Scripture 18 (1966), pp 8493.

Watson, G.R. The Roman Soldier, Thames \& Hudson, London (1969, reprinted 1983).

Webster, G. The Roman Imperial Army, A \& C Black, London (3rd edition 1981).

Williamson, G.A. The World of Josephus, Secker \& Warburg, London (1964).

Williamson, R. Jews in the Hellenistic World, Philo. Cambridge Commentaries on Writings on the Jewish and Christian World 200 BC - AD 200 lii, CUP, Cambridge (1989).

Winter, P. 'A Letter from Pontius Pilate' in NT 7 (1964), pp 37-43.

Wolfson, H.A. Philo (2 vols), Harvard University Press, Cambridge, Massachusetts (1947).

Zeitlin, S. 'Did Agrippa write a letter to Gaius Claigula?' JQR 56 (1965-6), pp 22-31. 
'Megillat Taanit as a Source for Jewish Chronology and History in the Hellenistic and Roman Periods', JQR 10 (1920), pp 237-287.

\section{Coins}

Hill, G. F. Catalogue of Coins in the British Museaum (Palestine), 1914, and (Phoenicia), 1910, London.

How gego, C.J. Greek Imperial Countermarks: Studies in the Provincial Coinage of the Roman Empire, Royal Numismatic Society, Special Publication no. 17, London (1985).

Kadman, L. 'The Development of Jewish Coinage' in The Dating and Meaning of Ancient Jewish Coins and Symbols, Publications of the Israeli Numismatic Society, Numismatic Studies and Researches Vol II, Jerusalem (1958).

Kindler, A. 'More Dates on the Coins of the Procurators, IEJ 6 (1956), pp 547.

Kindler, A. Coins of the Land of Israel (Collection of the Bank of Israel), Keter Publishing House, Jerusalem Ltd (1974).

Klimowsky, E. W. 'Danka and Prutah' in On Ancient Palestinian and Other Coins, their Symbolism and Metrology, Tel Aviv, (1974), (Publications of the Israeli Numismatic Society, Numismatic Studies and Researches Vol VII), pp 165-72.

Madden, F.W. History of Jewish Coinage and of Money in the Old and New Testament, KTAV Publishing House Inc, New York (1967), (first published 1864).

Madden, F.W. Coins of the Jews, Georg Olms, Hildesheim (1976), (first published Trübner \& Co, London, 1881).

Maltiel-Gerstenfeld, J.260 Years of Ancient Jewish Coins, Kol Printing Service Ltd, Tel Aviv (1982).

Maltiel-Gerstenfeld, J. New Catalogue of Ancient Jewish Coins, Minerva Associated, Tel Aviv (1987). 
Matthiae, K. and Schönert-Geiß, E. Muenzen aus der urchristlichen Umwelt, Evangelische Verlags-Anstalt, Berlin (1981).

Meshorer, Y. Ancient Jewish Coinage, Vol II: Herod the Great through Bar Cochba, Amphora Books, New York (1982).

Meyshan, Josef 'The Periods of the Jewish Coinage', pp 45-7, 'An Unusual Silver Penny (Prutah) Struck by the Roman Procurator of Judaea', pp 151-2 and 'What is the Prutah?, pp 49-53 in Essays in Jewish Numismatics, Publications of the Israel Numismatic Society, Numismatic Studies and Researches, Vol VI.

Oestreicher, B. The Denominations of Ancient Jewish Coins', Israeli .Numismatic Journal, Vol I (1963), pp 7-12.

Reifenberg, A. Ancient Jewish Coins, Rubin Mass, Jerusalem, Second Edition (revised) (1947).

Reinach T. Jewish Coins, ET Argonaut Inc, Chicago (1966).

Sutherland, C.H.V. 'Coinage', $O C D$ (2nd ed), pp 261-63.

\section{Roman Persecution of Christianity}

Bames, T.D. 'Legislation against the Christians', JRS 58(1968), pp 32-50.

Frend, W.H.C. Martyrdom and Persecution in the Early Church, Blackwell, Oxford (1965).

Garnsey, P. and Saller, R. The Roman Empire: Economy, Society and Culture, Duckworth, London (1987).

Guterman, S.L. Religious Persecution and Toleration in Ancient Rome, Aiglon Press, London (1951).

Hardy, E.G. Pliny's Correspondence with Trajan, Macmillan \& Co, London (1889).

Ramsey, W.M. The Church in the Roman Empire Before AD 170, Hodder \& Stoughton, London (1904).

Sherwin-White, A.N. Fifty Letters of Pliny, OUP, Oxford (1969).

The Early Persecutions and Roman Law Again', JTS NS 3 (1952), pp 199-213. 
de Ste Croix, G.E. M. 'Why Were the Early Christians Persecuted?', Past and Present 26 (1963), pp 6-38.

\section{MARK}

\section{Commentaries}

Anderson, H. The Gospel of Mark, New Century Bible, Oliphants, London (1976).

Belo, F. A Materialist Reading of the Gospel of Mark, Orbis Books, New York (E.T. 1981).

Blunt, A.W.F. Saint Mark, The Clarendon Bible, Oxford (1929).

Branscomb, B. H. The Gospel of Mark, Moffat NT Commentary, Hodder \& Stoughton Ltd, London (1937).

Carrington, P. According to Mark, CUP, Cambridge (1960).

Cole, A. Mark, Tyndale NT Commentaries, The Tyndale Press, London (1961).

Cranfield, C.E.B. St Mark, CUP, Cambridge (1959).

Gnilka, J. Das Evangelium Nach Markus, EKK II, Benziger/Neukirchener (1979).

Gould, E.P. St Mark, International Critical Commentary, T \& T Clark, Edinburgh (1896).

Gundry, R.H. Mark: A Commentary on his Apology for the Cross, Eerdman's, Grand Rapids (1993).

Hooker, M.D. The Gospel According to St Mark, Black's NT Commentaries, A \& C Black, London (1991).

lersel, van, B.M.F. Reading Mark, T \& T Clark, Edinburgh (1989).

Johnson, S.E. A Commentary on the Gospel According to St Mark, Adam \& Charles Black, London (1960).

Kee, H.C. Community of the New Age, SCM Press Ltd, London (1977).

Lane, W.L. The Gospel of Mark, The New International Commentary on the NT, Eerdmans Publishing Co. Ltd (1974). 
Lightfoot, R.H. The Gospel Message of St Mark, Clarendon Press, Oxford (1950).

Lohse, E. Mark's Witness to Jesus Christ, World Christian Books, United Society for Christian Literature, Lutterworth Press, London (1955).

Luihrmann, D. Das Markusevangelium, J.C.B. Mohr (Paul Siebeck), Tübingen (1987).

MacLear, G.F. St Mark, Cambridge Greek Testament for Schools and Colleges, CUP (1886).

Marxsen, W. Der Evangelist Markus: Studien zur Redaktionsgeschichte des Evangeliums. Forschungen zur Religion und Literatur des Alten und Neues Testaments, NF 49, Vandenhoeck und Ruprecht, Göttingen (1956).

Myers, C. Binding the Strong Man: A Political Reading of Mark's Story of Jesus, Orbis Books, Maryknoll (1988).

Nineham, D.E. The Gospel of St Mark, Pelican Gospel Commentaries, Adam \& Charles Black, London (1963).

Pesch, R. Das Markusevangelium, Vols I - II, Herders Theologischer Kommentar zum Neuen Testament, Herder, Freiburg (1977).

Plummer, A. St Mark, Cambridge Bible for Schools and Colleges, CUP, Cambridge (1915).

Plumtre, E.H. St Mark, Ellicotts NT Commentary, Cassell \& Company Ltd, London (1879).

Rawlinson, A.E.J. The Gospel According to St Mark, Westminster Commentaries, Methuen \& Co. Ltd, London (3rd ed. 1931).

Schweizer, E. The Good News According to Mark (Trans. D.H. Madrig), SPCK, London (1971).

Swete, H.B. The Gospel According to St Mark, Macmillan \& Co Ltd, London (1992).

Taylor, V. The Gospel According to St Mark, Macmillan \& Co. Ltd, London (1963). 
Williamson, L. Mark. Interpretation: A Biblical Commentary for Teaching and Preaching, John Knox Press, Louisville (1983).

\section{Other Works}

Bammel, E. The Trial before Pilate', in Jesus, ed. E. Bammel and C.F.D. Moule, pp 415-51.

Beavis, M.A. Mark's Audience: The Literary and Social Setting of Mk 4:1112, JSNT Supp 33, JSOT Press, Sheffield (1989).

Benoit, P. The Passion and Resurrection of Jesus Christ, Darton, Longman . and Todd, London (1969).

'Note sur les Fragments Grecs de la Grotte 7 de Qumran', $R B 79$ (1972), pp 321-4.

Best, E. The Temptation and the Passion: The Markan Soteriology, SNTS Monograph Series, CUP (1965).

Mark: The Gospel as Story, T \& T Clark, Edinburgh (1983).

Bruce, F.F. 'The Date and Character of Mark', in Jesus, ed. E. Bammel and C.F.D. Moule, pp 69-89.

Bultmann, R. History of the Synoptic Tradition (Tr. John Marsh), Blackwell, Oxford (1963).

Burkill, T.A. 'St Mark's Philosophy of the Passion', NT 2 (1957-8), pp 24571.

Burkill, T.A. Mysterious Revelation: An Examination of the Philosophy of St Mark's Gospel, Cornell University Press, New York (1963).

Cook, M.J. Mark's Treatment of the Jewish Leaders, Supp. NT vol LI, E.J. Brill, Leiden (1978).

Cullmann, O. The Christology of the New Testament, SCM, London (1959).

Donahue, J.R. 'A Pre-Markan Passion Narrative?' in Kelber, Passion, pp 120.

Dunn, J.D.G. 'Caesar', in DNTT, vol I, pp 269-70.

France, R.T. Divine Government, SPCK, London (1990). 
Hendrickx, H. The Passion Narratives of the Synoptic Gospels, Geoffrey Chapman, London (1977).

Hengel, M. Studies in the Gospel of Mark, SCM Press Ltd, London (1985).

Iersel, van, B.M.F. The Gospel According to St Mark - Written for a Persecuted Community?', NTT 34 (1980), pp 15-36.

Juel, D. Messiah and Temple, SBLDS 31, Scholars Press, Missoula (1977).

Kelber, W.H. The Passion in Mark (ed), Fortress Press , Philadelphia (1976). 'Conclusion: From Passion Narrative to Gospel' in Kelber, Passion, pp 153-80.

Kingsbury, J.D. Conflict in Mark: Jesus, Authorities, Disciples, Fortress Press, Mineapolis (1989).

Knox, W. L. The Sources of the Synoptic Gospels, vol I St Mark, CUP, Cambridge (1953).

Lindars, B. New Testament Apologetic, SCM, London (1961).

Linnemann, E. Studien zur Passionsgeschichte, FRLANT 102, Vandenhoeck \& Ruprecht, Göttingen (1970).

Malbon, E.S. Narrative Space and Mythic Meaning in Mark, JSOT Press, Sheffield (1991).

Martin, R.P. Mark - Evangelist and Theologian, Paternoster Press, Exeter (1972).

Matera, F.J. What Are They Saying About Mark?, Paulist Press, New York/Mahwah (1987).

Metzger, B.M. A Textual Commentary on the Greek New Testament, UBS, London (1975).

Meyer, E. Ursprung und Anfange des Christentums, 3 vols, Wissenschaftliche Buchgesellschaft, Darmstadt (1962, orig. 1921 3).

Neirynck, F. Duality in Mark: Contributions to the Study of the Markan Redaction, BETL 31, Leuven University Press, Leuven (2nd ed. 1988). 
Nickelsburg, G.W.E. The Genre and Function of the Markan Passion Narrative', HTR 73 (1980), pp 153-84.

Niederwimmer, K. 'Johannes Markus und die Frage nach dem Verfasser des zweiten Evangeliums', ZNW 58 (1967), pp 172-88.

O'Callaghan, J. 'Papiros neotestamentarios en la cueva 7 de Qumran?', Bib 53 (1972), pp 91-100.

Petersen, N.R. 'The Composition of Mk 4:1-8:26', HTR 73 (1980), pp 185217.

Piper, O.A. 'God's Good News: The Passion Story According to Mark', Interpretation 9 (1955), pp 165-82.

Streeter, B.H. The Four Gospels: A Study of Origins, Macmillan, New York (1929).

Taylor, D.B. Mark's Gospel as Literature and History, SCM Press, London (1992).

\section{MATTHEW}

\section{Commentaries}

Albright, W.F. and Mann, C.S. Matthew, Anchor Bible, Doubleday \& Co. Inc, New York (1971).

Allen, W.C. St Matthew, International Critical Commentary, T \& T Clark, Edinburgh (1907).

Beare, F.W. The Gospel According to Matthew, Blackwell, Oxford (1981).

Davies, W.D. and Allison, D.C. Matthew (3 vols), T \& T Clark, Edinburgh, (1991).

Edwards, R.A. Matthew's Story of Jesus, Fortress Press, Philadelphia (1985).

Fenton, J.C. Saint Matthew, Pelican Gospel Commentaries, Penguin Books (1963).

Filson, F.V. A Commentary on the Gospel according to St Matthew, Adam \& Charles Black, London (1960). 
Green, H.B. The Gospel According to Matthew, New Clarendon Bible, OUP, Oxford (1975).

Gundry, R.H. Matthew: A Commentary on his Literary and Theological Art, Eerdmans, Michigan (1982).

Hill, D. The Gospel of Matthew, New Century Bible, Oliphants, London (1972).

Kingsbury, J.D. Matthew, Proclamation Commentaries, Fortress Press, Philadelphia (1977).

Luz, U. Matthew 1-7. A Commentary, T \& T Clark, Edinburgh (1990).

Mc Neile, A.H. The Gospel According to St Matthew, Macmillan \& Co. Ltd, London (1938).

Minear, P.S. Matthew: the Teacher's Gospel, Darton, Longman and Todd, London (1982).

Plummer, A. An Exegetical Commentary on the Gospel according to St Matthew, Robert Scott, London (1909).

Patte, D. The Gospel According to Matthew, Fortress Press, Philadelphia (1987).

Robinson, T.H. The Gospel of Matthew, Moffatt NT Commentary, Hodder \& Stoughton, London (1928).

Schweizer, E. The Good News According to Matthew, SPCK, London (ET 1975).

Trilling, W. The Gospel According to St Matthew for Spiritual Reading, Sheed \& Ward, London (1969).

\section{Other Works}

Alexander, P.S. "'The Parting of the Ways" from the perspective of Rabbinic Judaism' in Jews and Christians, (ed J.D.G. Dunn), pp 1-25.

Balch, D.L. Social History of the Matthean Community: Cross Disciplinary Approaches (ed), Fortress Press, Mineapolis (1991). 
Buck, E. 'Anti-Judaic Sentiments in the Passion Narrative According to Matthew', in Anti-Judaism in Early Christianity, vol I, (ed. P. Richardson), Wilfred Laurier University Press, Waterloo, (1986).

Clark Wire 'Gender Roles in a Scribal Community' in Social History, (ed D.L. Balch), pp 87-121.

Davies, W.D. The Setting of the Sermon on the Mount, CUP, Cambridge (1964).

Derrett, J.D.M. 'Haggadah and the Account of the Passion' in Studies in the NT III, E.J. Brill, Leiden (1982), pp 184-92.

Dunn, J.D.G. The Partings of the Ways: between Christianity and Judaism and their Significance for the Character of Christianity, SCM, London (1991). Jews and Christians (ed), JCB Mohr (Paul Siebeck), Tübingen (1992).

Everts, J.M. 'Dreams', $A B D$, vol II, pp 231-2.

Farrer, A. St Matthew and St Mark, Dacre, Westminster (1954).

Fascher, E. Das Weib des Pilatus - die Auferweckung der Heiligen, Max Niemeyer Verlag, Halle (1951).

Fitzmyer, J.A. 'Anti-Semitism and the Cry of 'All the People' (Mt 27:25)', TS 26 (1965), pp 667-71.

France, R.T. Matthew: Evangelist and Teacher, Paternoster Press, Devon (1989).

Goulder, M. Midrash and Lection in Matthew, SPCK, London (1974).

Goodspeed, E.J. Matthew: Apostle and Evangelist, John C. Winston, Philadelphia (1959).

Gundry, R.H. 'A Responsive Evaluation of the Social History of the Matthean Community in Roman Syria' in Social History, (ed D.L. Balch), pp 62-7.

Hare, D.R.A. The Theme of Jewish Persecution of Christians in the Gospel According to St Matthew, CUP, Cambridge, (1967). 
Howell, D.B. Matthew's Inclusive Story: a Study in the Narrative Rhetoric of the First Gospel, JSNT Supp Series 42, JSOT Press, Sheffield (1990).

Jackson, B.S. 'On the Problem of Roman Influence on the Halakah and Normative Self-Definition in Judaism', in Jewish and Christian Self-Definition Vol II: Aspects of Judaism in the Graeco-Roman Period, Ed. E.P. Sanders with A.I. Baumgarten and A. Mendelson, SCM, London (1981), pp 157-203.

Kilpatrick, G.D. The Origins of the Gospel according to St Matthew, Clarendon Press, Oxford (1946).

Kingsbury; J.D. Matthew: Structure, Christology, Kingdom, SPCK, London (1976).

The Title Son of David in Matthew's Gospel', JBL 95 (1976), pp 598-601.

'Conclusion: Analysis of a Conversation', in Social History (ed. D.L. Balch), pp 259-269.

Koch, K. 'Der Spruch "Sein Blut bleibe auf seinem Haupt" und die israelitische Auffassung vom vergossenen Blut', VT 12 (1962), pp $396-416$.

Massaux, E. Influence de l'évangile de Saint Matthieu sur la littérature Chrétienne avant Saint Irénée, Leuven University Press, Leuven (1986).

Meier, J.P. 'Matthew and Ignatius: A Response to William R. Schoedel', in Social History, (ed D.L. Balch), pp 178-86. 'Matthew, Gospel of', in $A B D$, vol IV, pp 622-41.

Moo, D.J. 'Tradition and Old Testament in Mt 27:3-10' in Gospel Perspectives III, (ed. R.T. France and D. Wenham), JSOT Press (1983), pp 157-75.

Nolan, B.M. The Royal Son of God, Editions universitaires Fribourg Suisse Vandenhoeck \& Ruprecht, Göttingen, Orbis Biblicus et Orientalis 23 (1979). 
Przybylski, B. 'The Setting of Matthean Anti-Judasim', in Anti-Judaism in Early Christianity, vol I, (ed. P. Richardson), Wilfred Laurier University Press, Waterloo, (1986).

Quinn, J.F. 'The Pilate Sequence in the Gospel of Matthew', Dunwoodie Review 10 (1970), pp 154-77.

Reventlow, H.G. 'Sein Blut komme über sein Haupt', VT 10 (1960), pp 311 27.

Rosadi, G. The Trial of Jesus, Dodd Mead, New York (1905).

Saldarini, A.J. The Gospel of Matthew and Jewish-Christian Conflict' in Social History, (ed D.L. Balch), pp38-61.

Pharisees, Scribes and Sadducees in Palestinian Society, T \& T Clark, Edinburgh (1989).

Schelkle, K.H. 'Die "Selbstverfluchung" Israels nach Mt 27:23-5' in Antijudaismus im NT? (ed. W.P. Eckert), Kaiser, Munich (1967), pp 148-56.

Schoedel, W.R. 'Ignatius and the Reception of the Gospel of Matthew in Antioch', in Social History, (ed D.L. Balch), pp 129-77.

Segal, A.F. 'Matthew's Jewish Voice', in Social History, (ed D.L. Balch), pp 3-37.

Senior, D. 'The Fate of the Betrayer', EThL 48 (1972), pp 372-426. The Passion Narrative According to Matthew: A Redactional Study, Bibliotheca Ephemeridum Theologicarum Lovaniensium 39, Leuven University Press (1975).

Slingerland, D.L. 'The Transjordanian Origin of Matthew's Gospel', JSNT 3 (1979), pp 18-28.

Stanton, G.N. A Gospel for a New People: Studies in Matthew, T \& T Clark, Edinburgh (1992).

Stark, R. 'Antioch as the Social Situation for Matthew's Gospel', in Social History, (ed D.L. Balch), pp 189-210.

Streeter, B.H. The Four Gospels: A Study of Origins, Macmillan, London (1924). 
van Tilborg, S. The Jewish Leaders in Matthew, E.J. Brill, Leiden (1972).

van Unnik, W.C. The Death of Judas in St Mark's Gospel' in Gospel Studies in Honour of S.E. Johnson, AThR Supp Series 3, pp 44-57.

Viviano, B.T. 'Where was the Gospel According to Matthew Written?', $C B Q$ 41 (1972), pp 182-184.

Vögtle, A. 'Die Matthäische Kindheitsgeschichte', in L'Evangile selon Matthieu: Rédaction et Théologie, (ed. M. Didier), BETL 29, Ducalot, Gembloux (1972).

White, L.M. 'Crisis Management and Boundary Maintenance', in Social History, (ed D.L. Balch), pp 211-247.

\section{LUKE}

Commentaries

Caird, G.B. The Gospel of St Luke, Pelican Gospel Commentaries, Penguin, Baltimore (1963).

Creed, J.M. The Gospel According to St Luke, Macmillan \& Co, London (1930).

Danker, F.W. A Commentary on Luke's Gospel, Fortress Press, Philadelphia (1988).

Ellis, E.E. The Gospel of Luke, Century Bible, Nelson, London (1966).

Evans, C.F. St Luke, SCM, London (1990).

Fitzmyer, J.A. The Gospel According to Luke, Anchor Bible Commentary vols 28 \& 28a, Doubleday \& Co, New York (1983).

Goulder, M.D. Luke - A New Paradigm, vol II, JSNT Supp Series 20, JSOT Press, Sheffield (1989).

Grundmann, W. Das Evangelium nach Lukas, Theologischer Handkommentar zum Neun Testament III, Evangelische Verlagsanstalt, Berlin (1971).

Leaney, A.R.C. A Commentary on the Gospel According to St Luke, A \& C Black (2nd ed. 1966). 
Loisy, A. L'Evangile selon Luc, E. Nourry, Paris (1924).

Manson, W. The Gospel of Luke, Moffat NT Commentary, Hodder \& Stoughton, London (1930).

Marshall, I.H. The Gospel of Luke, Paternoster Press, Exeter (1978).

Morris, L. The Gospel According to St Luke: An Introduction and Commentary, TNTC, Eerdmans, Grand Rapids (1974).

Talbert, C.H. Reading Luke: A New Commentary for Preachers, SPCK, London (1982).

Tannehill, R.C. The Narrative Unity of Luke-Acts, Fortress Press, Philadelphia (1986).

Wellhausen, J. Das Evangelium Lucae übersetżt und eklärt, G. Reimer, Berlin (1904).

\section{Other Works}

Bailey, A. The Traditions Common to the Gospels of Luke and John, NovT Supp 7, E.J. Brill, Leiden (1963).

Black, M. 'The Arrest and Trial of Jesus and the Date of the Last Supper', New Testament Essays: Studies in Memory of Thomas Walter Manson 1893-1958, (ed. A.J.B. Higgins), Manchester University Press, Manchester (1959), pp 19-33.

Blinzler, J. 'Herodes und der Tod Jesu', Kerusblatt 37 (1957), pp 118-21. 'Die Niedermetzelung von Galilaern durch Pilatus', NovT2 (1958), pp $24-49$.

Burkill, T.A. The Condemnation of Jesus: A Critique of Sherwin-White's thesis', NovT 12 (1970), pp 321-42.

Bruce, F.F. 'Render to Caesar', in Jesus, (ed. E.Bammel and C.F.D. Moule), pp 249-63.

Cadbury, H.J. The Style and Literary Method of Luke: I The Diction of Luke and Acts, Harvard Theological Studies VI, Harvard Universtiy Press, Cambridge (1919).

The Making of Luke-Acts, SPCK, London (1958). 
Carroll, J.T. 'Luke's Crucifixion Scene' in Sylva, Reimaging, pp 108-124.

Cassidy, R.J. Jesus, Politics and Society: A Study of Luke's Gospel, Orbis Books, New York (1978). and Scharper, P.J. Political Issues in Luke-Acts, Orbis Books, New York (1983).

Conzelmann, H. The Theology of St Luke, Faber \& Faber, London (E.T. 1960).

'Luke's Place in the Development of Early Christianity' in Studies in Luke-Acts, (ed. L.E. Keck and J.L. Martyn), SPCK, London (1968).

Acts of the Apostles, Hermeneia, Fortress Press, Philadelphia (1987).

Corbin, M. 'Jésus devant Hérode: Lecture de Luc 23,6-12', Christus 25 (1978), pp 190-7.

Cullmann, O. The State in the New Testament, SCM, London (1957).

Derrett, J.D.M. 'Luke's Perspective on Tribute to Caesar' in Cassidy and Scharper, Political, pp 38-48.

'The Galileans and the Tower' in New Resolutions of Old Conundrums: A Fresh Insight into Luke's Gospel, Drinkwater (1986), pp 100-10.

Dibelius, M. 'Herodes und Pilatus', ZNW 19 (1915), pp 113-26.

From Tradition to Gospel, Library of Theological Translations, James Clark, Cambridge (1971).

Esler, P.F. Community and Gospel in Luke-Acts: The Social and Political Motivations of Lucan Theology, CUP, Cambridge (1987).

Evans, C.A. 'Is Luke's View of the Jewish Rejection of Jesus Anti-Semitic? in Sylva, Reimaging, pp 29-56.

Finegan, J. The Original Form of the Pauline Collection', HTR 49 (1956), pp 85-103. 
Freyne, S. 'Bandits in Galilee: A Contribution to the Study of Social Conditions in First-Century Palestine' in J. Neusner et al (eds), The Social World of Formative Christianity and Judaism: Essays in Tribute to Howard Clark Kee, Fortress Press, Philadelphia (1988), pp 53ff.

Green, J. 'The Death of Jesus, God's Servant' in Sylva, Reimaging, pp 1-28.

Hoehner, H.W. 'Why did Pilate hand Jesus over to Antipas?' in Trial of Jesus: Studies in Honour of Moule, (ed. E. Bammel), SCM (1970), pp $84-90$.

Jeremias, J. The Eucharistic Words of Jesus, SCM, London (1966). Jerusalem in the Time of Jesus: An Investigation into Economic and Social Conditions during the New Testament Period, SCM, London (1969).

Johnson, L.T. 'Luke-Acts, Book of', $A B D$, vol IV, pp 403-20.

Johnson, S.E. 'A Note on Luke 13:1-5', ATR 17 (1935), pp 91-5.

Juel, D. Luke-Acts, SCM, London (1984).

Karris, R.J. 'Luke 23:47 and the Lucan View of Jesus' Death' in Sylva, Reimaging, pp 68-78.

Kilpatrick, D. 'A Theme of the Lukan Passion Story and Lk 23:47', JTS 43 (1942), pp 347.

Klein, H. 'Zur Frage nach dem Abfassungsort der Lukasschriften', Ev.T32 (1972), pp 467-77.

Luomanen, P. Luke-Acts: Scandinavian Perspectives (ed), Finnish Exegetical Society in Helsinki 54, Vandenhoeck \& Ruprecht, Göttingen (1991).

Maddox, R. The Purpose of Luke-Acts, T \& T Clark, Edinburgh (1982).

Matera, F.J. 'Luke 22, 66-71: Jesus before the ПPESBYTEPION', in L'Évangile de Luc/The Gospel of Luke, Revised and Enlarged Edition of L'Évangile de Luc, Problemes littéraires et théologiques, (ed. F. Neirynck), Leuven University Press, Leuven (1989), pp 517-33. 
'Luke 23, 1-25: Jesus before Pilate, Herod and Israel', ibid, pp 53551.

Moessner, D.P. The "Leaven of the Pharisees" and "This Generation": Israel's Rejection of Jesus According to Luke' in Sylva, Reimaging, pp 79-107.

Moxnes, H. The Economy of the Kingdom: Social Conflict and Economic Relations in Luke's Gospel, Fortress Press, Philadelphia (1988).

Myllykoski, M. 'The Material Common to Luke and John: A Sketch' in LukeActs (ed. P. Luomanen), pp 115-56.

Olmstead, A.T. Jesus in the Light of History, Scribner's, New York (1942).

O'Neil, J.C. The Theology of Acts in its Historical Setting, SPCK, London (1961).

Rau, G. 'Das Volk in der lukanischen Passionsgeschichte, eine Konjektur zu Lc 23.13', ZNW 56 (1965), pp 41-51.

Reese, T. The Political Theology of Luke-Acts', Biblical Theology 22 (1972), pp 62-5.

Richard, E. 'Jesus' Passion and Death in Acts' in Sylva, Reimaging, pp 125152.

Rienecker, F. A Linguistic Key to the Greek New Testament, vol I: Matthew Acts (Translated and revised by C.L. Rogers), Bagster, London (1977).

Robinson, J.A.T. Redating the New Testament, Westminster, Philadelphia (1976).

Sanders, J.T. The Jews in Luke-Acts, SCM, London (1987).

Schneider, G. 'The Political Charge against Jesus (Luke 23:2)', in Jesus, (ed. E. Bammel and C.F.D. Moule), pp 403-414.

Soards, M.L. 'Herod Antipas' Hearing in Luke 23:8', Biblical Theology 37 (1986), pp 146-7.

The Passion According to Luke: The Special Material of Luke 22, JSOT Supp Ser 14, JSOT Press, Sheffield (1987). 
Strobel, A. 'Lukas der Antiochener (Bemerkungen zu Act 11,28D)', ZNW 49 (1958), pp 131-4.

Sylva, D.D. (Ed) Reimaging the Death of the Lukan Jesus, Athenäum Monografien, Theologie, Bonner Biblische Beiträge 73, Anton Hain, Frankfurt (1990).

Tannehill, R.C. The Narrative Unity of Luke-Acts, Fortress Press, Philadelphia (1986).

Taylor, V. The Passion Narrative of St Luke: A Critical and Historical Investigation, SNTS Monograph Series 19, CUP, Cambridge (1972).

Vermes, G. Jesus the Jew, SCM, London (2nd ed. 1983).

Verrall, A.W. 'Christ Before Herod', JTS 10 (1909), pp 321-53.

Walaskay, P.W. The Trial and Death of Jesus in the Gospel of Luke', JBL 94 (1973), pp 81-93.

And so we came to Rome: The Political Perspective of St Luke, CUP, Cambridge (1983).

\section{$J O H N$}

Commentaries

Barrett, C.K. The Gospel According to St John, SPCK, London (2nd ed. 1978).

Brown, R.E. The Gospel According to John, Geoffrey Chapman, London (1978).

Bultmann, R. The Gospel of John: A Commentary, Westminster Press, Philadelphia (ET 1971) \{German original 1964\}.

Haenchen, E. Das Johannesevangelium, J.C.B. Mohr (Paul Siebeck), Tübingen (1980).

Lightfoot, R.H. St John's Gospel: A Commentary, Clarendon Press, Oxford (1956).

Lindars, B. The Gospel of John, Marshall, Morgan \& Scott, London (1972). 
Macgregor, G.H.C. The Gospel of John, Moffat NT Commentaries, Hodder \& Stoughton, London (1942).

Marsh, J. The Gospel of St John, Pelican NT Commentaries, Penguin, London (1968).

Morris, L. The Gospel According to John, New International Commentary on the NT Series, Eerdmans, Grand Rapids (1971).

Schnackenburg, R. The Gospel According to St John, 3 vols, Burns \& Oates, London (1980).

Westcott, B.F. The Gospel According to St John, John Murray, London (1898).

\section{General Works}

Alter, R. The Art of Biblical Narrative, Basic Books, New York (1981).

Bammel, E. 'Crucifixion as a Punishment in Palestine', in Trial, pp 162-5.

The titulus', in Jesus, (ed. E. Bammel and C.F.D. Moule), pp 353-64.

Barrett, C.K. The Gospel of John and Judaism, SPCK, London (1975).

Bassler, J.M. The Galileans: A Neglected Factor in Johannine Community Research', $C B Q 43$ (1981), pp 243-57.

Baum-Bodenbender, R. Hoheit in Niedrigkeit: Johannische Christologie im Prozess Jesu vor Pilatus (Joh 18,28 - 19,16a), FzB 49, Würzburg (1984).

Baumgarten, J.M. 'Does TLH in the Temple Scroll Refer to Crucifixion?', JBL 91 (1972), pp 472-81.

Blank, J. 'Die Verhandlung vor Pilatus: Joh 18,28-19,26 im Lichte der Joh. Theologie', BZ3 (1959), pp 60-81.

Blinzler, J. 'Der Entscheid des Pilatus - Executionsbefehl oder Todesurteil?', MTZ 5 (1954), pp 171-84.

Borgen, P. 'John and the Synoptics in the Passion Narrative', NTS 5 (1958-9), pp 246-59.

Borig, R. Der Wahre Weinstock, Kösel, Munich (1967). 
Brown, R.E. The Community of the Beloved Disciple, Geoffrey Chapman, London (1979).

Buse, S.I. 'St John and the Markan Passion Narrative', NTS 4 (1957-8), pp 215-9.

_St John and the Passion Narratives of St Matthew and St Luke', NTS 7 (1960-1), pp 65-70.

Cassidy, R.J. John's Gospel in New Perspective, Orbis Books, New York (1992).

Culpepper, R.A. Anatomy of the Fourth Gospel: A Study in Literary Design, Fortress Press, Philadelphia (1983).

de la Potterie, I. 'L'arrière-fond du theme johannique de verité', Studia Evangelica I, Akademie-Verlag, Berlin, pp 277-94.

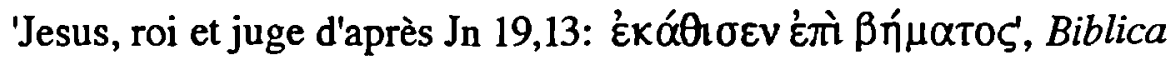
41 (1960), pp 217-47.

Dodd, C.H. The Interpretation of the Fourth Gospel, CUP, Cambridge (1953) Historical Tradition in the Fourth Gospel, CUP, Cambridge (1965).

Duke, P. Irony in the Fourth Gospel, John Knox Press, Atlanta (1985).

Dunn, J.D.G. 'Let John be John' in Das Evangelium und die Evangelien, (ed. Peter Stuhlmacher), JCB Mohr (Paul Siebeck), Tübingen (1983), pp 309-39.

Ehrman, B.D. 'Jesus' Trial before Pilate: John 18:28-19:16', BTB 13 (1983), pp 124-31.

Evans, C.F. The Passion in John' in Explorations in Theology 2, SCM, London (1977), pp 50-66.

Fitzmyer, J.A. 'Crucifixion in Ancient Palestine, Qumran Literature and the New Testament', $C B Q 40$ (1978), pp 493-513.

Flourney, P.P. 'What Frightened Pilate?, BSac 82 (1925), pp 314-20.

Ford, J.M. 'Crucify him, Crucify him and the Temple Scroll', ExpT 87 (19756), pp 275-8.

Fortna, R.T. The Gospel of Signs, CUP, Cambridge (1970). 
Gardner-Smith, P. St John and the Synoptic Gospels, CUP, Cambridge (1938).

Giblin, C.H. 'John's Narration of the Hearing Before Pilate (John 18,28 19,16a)', Bib 67 (1986), pp 221-39.

Haenchen, E. 'Jesus vor Pilatus (Joh 18,28-19,15)', TLZ 85 (1960), cols 93 102.

'History and Interpretation in the Johannine Passion Narrative', Interpretation 24 (1970), pp 198-219.

Hart, H.St.J. 'The Crown of Thorns in John 19.2-5', JTS NS 3 (1952), pp 6675.

Hengel, M. The Johannine Question, SCM, London (1989).

'Reich Christi, Reich Gottes und Weltreich im Johannesevangelium', in 'Königsherrschaft Gottes und himmlischer Kult' im Judentum, Urchristentum und in der hellenistischen Welt, (ed. M. Hengel and A.M. Schwemer), Wissenschaftliche Untersuchungen zum NT 55, JCB Mohr (Paul Siebeck), Tübingen (1991).

Kysar, R. The Fourth Evangelist and His Gospel: An Examination of Contemporary Scholarship, Augsburg, Minneapolis (1975). 'John, the Gospel of', $A B D$, vol III, pp 912-31.

Lee, E.K. 'St Mark and the Fourth Gospel', NTS (1956-7), pp 50-8.

Leon-Dufour, X. 'Trois Chiasmes johanniques', NTS 7 (1960-61), pp 249-55.

Lund, N.W. The Influence of Chiasmus upon the Structure of the Gospels', ATR 13 (1931), pp 27-48, 405-33.

Martyn, J.L. History and Theology in the Fourth Gospel, Harper \& Row, New York (1968).

Mayer, R. 'Israel', in DNTT, esp. pp 310-1.

Meeks. W.A. The Prophet King: Moses Traditions and the Johannine Christology, NT Supp 14, E.J. Brill, Leiden (1967). 
'Breaking Away: Three New Testament Pictures of Christianity's

Separation from the Jewish Communities', in To See Ourselves as

Others See Us': Christians, Jews, 'Others' in Late Antiquity, (ed. J. Neusner and E. Frerichs), Scholars Press, California (1985), pp 93-115.

Millar, F. 'Reflections on the Trial of Jesus' in A Tribute to Geza Vermes: Essays on Jewish and Christian Literature and History, (ed. P.R. Davies and R.T. White), JSOT Press, Sheffield (1990), pp 355381.

Neirynck, F. 'John and the Synoptics: 1975-90', Paper given at the 39th Colloquium Biblicum Lovaniense (1990), Leuven University Press, Leuven (1992).

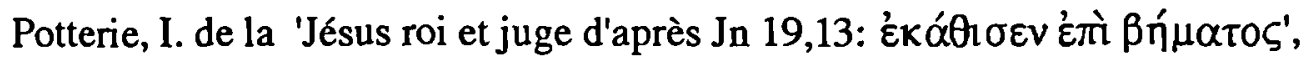
Bib 41 (1960), pp 217-47.

Rensberger, D. Overcoming the World: Politics and Community in the Gospel of John, SPCK, London (1989), \{First published in the USA by Westminster Press, Philadelphia (1988) as Johannine Faith and Liberating Community\}.

Sabbe, M. The Trial of Jesus before Pilate in John (18:28-19:16a) and its Relation to the Synoptists', Paper given at the 39th Colloquium Biblicum Lovaniense (1990), Leuven University Press, Leuven (1992), pp 467-513.

Schlier, H. 'Jesus und Pilatus nach dem Johannes Evangelium' in Die Zeit der Kirche, Herder, Freiburg (1956), pp 56-74.

The State According to the New Testament' in The Relevance of the New Testament, Herder \& Herder, New York (1968), pp 215-38.

Segovia, F.F. 'The Love and Hatred of Jesus and Johannine Sectarianism', $C B Q 43$ (1981), pp 258-72.

Stibbe, M.W.G. John as Storyteller: Narrative Criticism and the Fourth Gospel, SNTS Monograph Series 73, CUP, Cambridge (1992).

von Wahlde, U.C. The Johannine "Jews": A Critical Survey', NTS 28 (1982), pp 33-60. 
Wengst, K. Bedrängte Gemeinde und verherrlichter Christus: Der historische Ort des Johannesevangeliums als Schlüssel zu seiner Interpretation, Biblisch Theologische Studien 5, Neukirchener Verlag, Neukirchen (1981).

Yadin, Y. 'Pesher Nahum (4Q Nahum) Reconsidered', IEJ 21 (1971), pp 112.

General Works on the Trial of Jesus (not previously cited)

Bajsic, A. 'Pilatus, Jesus und Barabbas', Bib 48 (1967), pp 7-28.

Bammel, E. The Trial of Jesus (ed.), SCM, London (1970). 'The Trial Before Pilate' in Jesus and the Politics of his Day, (ed. E. Bammel, C.F.D. Moule), CUP, Cambridge (1984), pp 415-451. The Titulus' in Jesus and the Politics of his Day, Ed. E. Bammel, C.F.D. Moule, CUP, Cambridge (1984), pp 353-64.

Blinzler, J. Der Prozeß Jesu (1951); ET: The Trial of Jesus, Mercier Press, Cork (1959).

Brandon, S.G.F. The Trial of Jesus of Nazareth, B.T. Batsford, London (1968).

Brown, R.E. The Death of the Messiah: From Gethsemane to the Grave. A Commentary on the Passion Narratives in the Four Gospels, Doubleday, New York (1994).

Burkill, T.A. The Condemnation of Jesus: A Critique of Sherwin-White's Thesis', NovT 12 (1970), pp 321-42.

Catchpole, D.R. 'The Problem of the Historicity of the Sanhedrin Trial', in Bammel, Trial, pp 47-65.

The Trial of Jesus, EJ. Brill, Leiden (1971).

Chaval, C.B. The Releasing of a Prisoner on the Eve of Passover in Ancient Jerusalem', JBL 60 (1941), pp 273-78.

Cohn, H. The Trial of Jesus, Harper \& Row, New York (1967),

Cullmann, O. The State in the New Testament, SCM, London (1957). 
Davies, S.L. 'Who is Called Bar Abbas?', NTS 327 (1981), pp 260-2.

Dunkerley 'Was Barabbas also called Jesus?', ExpT 74, pp 126-7.

Finegan, J. Handbook of Biblical Chronology, Princeton University Press, Princeton (1964).

Fotheringham, J.K. The Evidence of Astronomy and Technical Chronology for the Date of the Crucifixion', JTS 35 (1934), pp 146-62.

Harvey, A.E. Jesus on Trial: A Study in the Fourth Gospel, SPCK, London (1976). Jesus and the Constraints of History, Duckworth, London (1982).

Horvath, T. 'Why Was Jesus Brought to Pilate?', NovT 11 (1969), pp 17484.

Husband, R.W. The Pardoning of Prisoners by Pilate', AJT 21 (1917), pp 110-16.

Kilpatrick, G.D. The Trial of Jesus, OUP, Oxford (1953).

Langdon, S. The Release of a Prisoner at the Passover', ExpT 29 (1917-8), pp 328-30.

Lietzmann, 'Der Prozeß Jesu', Kleine Schriften II: Studien zum Neun Testament, Berlin (1958).

Maccoby, H.Z. 'Jesus and Barabbas' NTS 16(1969-70), pp 55-60.

Merritt, R.L. 'Jesus Barabbas and the Paschal Pardon', JBL 104 (1985), pp $57-68$.

Nevius, R. 'A Reply to Dr Dunkerley', ExpT 74 (1962/3), p 255.

Rigg, H.A. 'Barabbas', JBL 64 (1945), pp 417-56.

Rivkin, E. What Crucified Jesus?, SCM, London (1986).

Sherwin-White, A.N. 'The Trial of Christ' in Historicity and Chronology in the New Testament, D.E. Nineham et al, SPCK, London (1965), pp 97-116.

Sloyan, G. Jesus on Trial, Fortress Press, Philadelphia (1973).

Twomey, J.J. 'Barabbas was a Robber', Scripture 8 (1956), pp 115-9.

Winter, P. On the Trial of Jesus, Walter de Gruyter \& Co, Berlin (1961). 